MANUEL MORENO RUIZ POVEDA

\title{
ANÁLISE ECONÔMICA E AMBIENTAL DO PROCESSAMENTO DA VINHAÇA COM APROVEITAMENTO ENERGÉTICO
}

Dissertação apresentada ao Programa de PósGraduação em Energia do Instituto de Energia e Ambiente da Universidade de São Paulo para obtenção do título de Mestre em Ciências

Orientadora: Profa. Dra. Suani Teixeira Coelho

Versão corrigida

\section{São Paulo}


AUTORIZO A REPRODUÇÃO E DIVULGAÇÃO TOTAL OU PARCIAL DESTE TRABALHO, POR QUALQUER MEIO CONVENCIONAL OU ELETRÔNICO, PARA FINS DE ESTUDO E PESQUISA, DESDE QUE CITADA A FONTE.

FICHA CATALOGRÁFICA

Poveda, Manuel.

Análise econômica e ambiental do processamento da vinhaça com aproveitamento energético; Manuel Moreno Ruiz Poveda; Orientadora Suani Teixeira Coelho. São Paulo, 2014. 160 f. Il.; $30 \mathrm{~cm}$.

Dissertação (Mestrado em Ciências) - Programa de PósGraduação em Energia - Instituto de Energia e Ambiente da Universidade de São Paulo.

1.Etanol 2.Vinhaça 3.Bioenergia I.Título. 
Nome: POVEDA, Manuel Moreno Ruiz

Titulo: Análise econômica e ambiental do processamento da vinhaça com aproveitamento energético

Dissertação apresentada ao Programa de PósGraduação em Energia do Instituto de Energia e Ambiente da Universidade de São Paulo para obtenção do título de Mestre em Ciências

Aprovado em

Banca examinadora:

Prof. Dr. Instituição:

Julgamento Assinatura:

Prof. Dr. Instituição:

Julgamento Assinatura:

Prof. Dr. Instituição:

Julgamento Assinatura: 


\section{DEDICATÓRIA}

Com toda humildade, dedico este trabalho ao povo brasileiro. 


\section{AGRADECIMENTOS}

Ao povo brasileiro, pela acolhida.

À minha orientadora, Profa. Dra. Suani Teixeira Coelho, pelo tempo e pela dedicação.

Aos colegas do CENBIO, pela colaboração.

A Monique, pela companhia, pelo carinho, pelo apoio e pela compreensão.

À Coordenação de Aperfeiçoamento de Pessoal de Nível Superior, pelo financiamento. 
Tudo é considerado impossível, até acontecer.

Nelson Mandela 


\section{RESUMO}

POVEDA, Manuel Moreno Ruiz. Análise econômica e ambiental do processamento da vinhaça com aproveitamento energético. 2014. 150 f. Dissertação (Mestrado em Ciências) Programa de Pós-Graduação em Energia da Universidade de São Paulo, São Paulo, 2014.

A vinhaça é o principal resíduo da produção de etanol de cana-de-açúcar e, no Brasil, são gerados aproximadamente 250 milhões de $\mathrm{m}^{3}$ de vinhaça por safra. Atualmente, este efluente é usado para fertirrigação dos canaviais em sua forma in natura, ou seja, sem tratamento prévio. Devido à sua grande quantidade de matéria orgânica e de sais, a disposição inadequada no meio ambiente pode ser causa tanto de impactos no solo e na água, como de emissões de gases de efeito estufa. O objetivo geral deste estudo é comparar diferentes alternativas de processamento para o aproveitamento energético da vinhaça, em busca daquela com maior desenvolvimento tecnológico, que mitigue os possíveis impactos ambientais da fertirrigação com vinhaça in natura e que esteja associada a um menor custo. Para esta finalidade, foram configurados cinco cenários que representam as tecnologias mais estudadas atualmente. Como cenário de referência, foi estabelecido a fertirrigação com vinhaça in natura e, como suas alternativas, consideraram-se: 1.concentração, 2.biodigestão e 3.incineração com produção de energia elétrica, bem como 4.combinação da biodigestão com a concentração e com o uso veicular do biogás. Uma vez feita a avaliação, concluiu-se que todas as alternativas melhoram o desempenho ambiental da gestão do resíduo e, ao mesmo tempo, permitem o aproveitamento e a economia de energia. Entretanto, o sistema de concentração é a única opção que se mostra viável economicamente na situação atual. Para ser atrativo o investimento nas demais tecnologias, seria necessária a introdução de medidas que premiem monetariamente os serviços ambientais, tais como a mitigação de emissões de gases de efeito estufa, a redução do consumo de água e a produção de energia a partir de fontes renováveis. A combinação da biodigestão com a posterior concentração pode ser a opção que reúne o maior número de vantagens com respeito ao cenário de referência. Com esta combinação, o biogás produzido é utilizado para suprir o consumo de energia do processamento e para substituir o diesel na frota usada na produção da cana-de-açúcar. Relativo aos impactos ambientais, esta configuração tecnológica diminui o volume da vinhaça, facilita sua distribuição a longas distâncias, evita a concentração de nutrientes no entorno das usinas, elimina o odor da decomposição da vinhaça e as emissões de metano, possibilita a reutilização da água e permite a substituição de combustíveis fósseis. Além disso, a vinhaça biodigerida e concentrada tem boas qualidades como fertilizante.

Palavras-chave: Vinhaça, Etanol, Concentração, Biodigestão, Incineração, Biogás. 


\begin{abstract}
POVEDA, M. M. R. Economic and environmental analysis of vinasse processing with energy recovery. 2014. 150 p. Master's Dissertation - Graduate Program on Energy, University of São Paulo, São Paulo, 2014.
\end{abstract}

The vinasse is the main residue of ethanol production from sugarcane. In Brazil, around 250 million $\mathrm{m}^{3}$ of vinasse are generated per harvesting season. Currently, this effluent is used in natura, ie, without previous treatment, for sugarcane fertirrigation. Due to its large amount of organic matter and salts, inadequate disposal in the environment may cause impacts on soil and water, as well as greenhouse gases emissions. This study aims to compare different alternative process for vinasse energy recovery, searching which ones have the highest technological development nowadays, mitigate the possible environmental impacts of fertirrigation using in nature vinasse and involve the lowest cost. For this purpose, five scenarios were configured, representing the most widely studied technologies. As the baseline scenario it was established fertirrigation using in nature vinasse and, as alternatives scenarios, the following ones were considered: 1. concentration, 2. digestion and 3. incineration with electricity generation, and 4. digestion plus concentration with vehicular use of biogas. It was concluded that all the alternatives improve the environmental performance of vinasse management since they also allow energy recovery and savings. However, only vinasse concentration system is economically feasible nowadays. For the other technologies to become an attractive investment, it would be necessary to include an economic valuation of environmental services, such as greenhouse gas emissions mitigation, reduction of water consumption and renewable energy production. The combination of digestion and subsequent concentration may be the option that brings together the largest number of advantages comparing to the baseline scenario. In this solution, the biogas produced is used to supply the process power consumption and to replace diesel in the fleet used for sugarcane production. Regarding the environmental impacts, this technology configuration reduces vinasse`s volume, facilitates its distribution to long distances, prevents nutrient concentration around mills, eliminates decomposition odor and methane emissions, enables water reuse and allows fossil fuels replacement. Furthermore, digested and concentrated vinasse has good qualities as fertilizer.

Keywords: Vinasse, Ethanol, Concentration, Digestion, Incineration, Biogas. 


\section{LISTA DE FIGURAS}

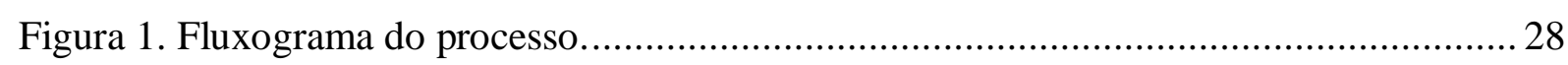

Figura 2. Produção estimada de vinhaça no Brasil.......................................................... 29

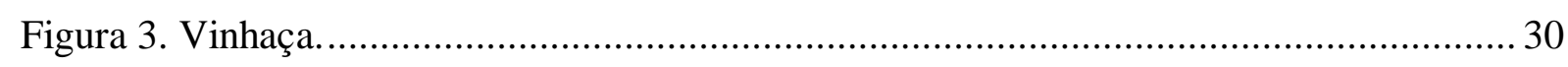

Figura 4. Descarga rápida defletida em pratos de um caminhão-tanque sobre a lavoura........ 34

Figura 5. Aspersor tipo montagem direta sugada de canal. ............................................... 34

Figura 6. Carretel enrolador com captação no canal e acoplado diretamente no caminhão. ... 35

Figura 7. Distância econômica de fertirrigação............................................................... 36

Figura 8. Evaporador de película descendente. ................................................................ 38

Figura 9. Tecnologia Thermally Accelerated Short Time Evaporator (TASTE)................... 39

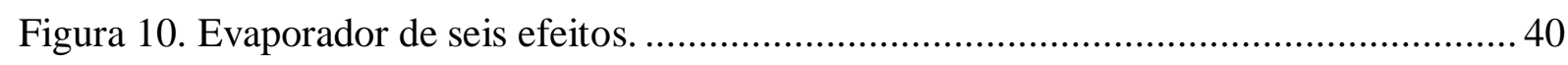

Figura 11. Concentrador de vinhaça Ecovin. .................................................................. 41

Figura 12. Caminhão aplicando vinhaça concentrada. ................................................... 42

Figura 13. Processo de biodigestão anaeróbia................................................................. 43

Figura 14. UASB. Reator anaeróbio de fluxo ascendente................................................ 44

Figura 15. Reator anaeróbio de Circulação Interna (IC) ................................................. 45

Figura 16. Esquema do processo do biodigestor da Usina São Martinho............................... 51

Figura 17. Esquema do processo do biodigestor da Usina Ester......................................... 52

Figura 18. Imagem do sistema de biodigestão da Usina Ester. ............................................. 53

Figura 19. Esquema básico de Instalação Térmica de Concentração para Combustão de

Vinhaça e Geração de Energia Elétrica............................................................................... 55

Figura 20. Queimador para queima de gás natural e vinhaça concentrada. ........................... 56

Figura 21. Queimador torsional Saacke para vinhaça concentrada de melaço, modelo SSB de

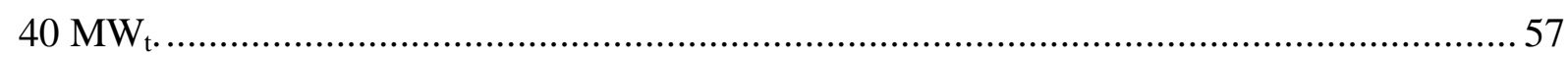

Figura 22. Recuperação de calor e potência na incineração de vinhaça. ............................... 58

Figura 23. Planta de combustão da vinhaça da destilaria Bangyikhan (Tailândia). ................ 59

Figura 24. Diagrama ilustrativo e de fluxos do Cenário 0 de referência, Fertirrigação com

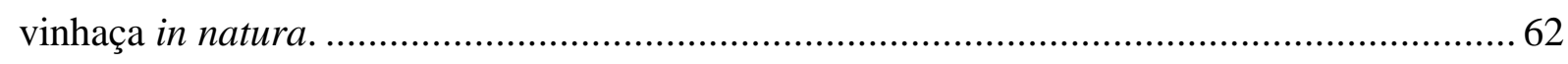

Figura 25. Diagrama explicativo e de fluxos do Cenário 1, Concentração evaporativa. Fonte: Autor. 63

Figura 26. Diagrama explicativo e de fluxos do Cenário 2, Biodigestão anaeróbia com geração de eletricidade. 64 
Figura 27. Diagrama explicativo e de fluxos do Cenário 3, Incineração com geração de eletricidade.

Figura 28. Diagrama explicativo e de fluxos do Cenário 4, Biodigestão com concentração e uso veicular.

Figura 29. Representação do sistema de cogeração e diagrama termodinâmico ideal T-S do ciclo que supre o evaporador no Cenário 1.

Figura 30. Representação do sistema de cogeração e diagrama termodinâmico ideal T-S do ciclo que supre o evaporador no Cenário 4.

Figura 31. Balanço energético em cada cenário de tratamento da vinhaça em usinas de etanol de cana.

Figura 32. Representação esquemática do efeito da Norma P4.231 sobre a fertirrigação com vinhaça.

Figura 33. Tendência das concentrações de nitrato no Aquífero Bauru, no período de 1998 a 2012

Figura 34. Balanço de emissões de GEEs dos cenários.

Figura 35. Emissões por fonte nos diferentes cenários.

Figura 36. Balanço de emissões de $\mathrm{NO}_{\mathrm{x}}$ e $\mathrm{SO}_{\mathrm{x}}$ dos Cenários.

Figura 37. Relação entre o preço da eletricidade e do CER para que o Cenário 2 tenha uma TIR $=21 \%$.

Figura 38. Histórico do preço das CER.

Figura 39. Relação entre o preço da eletricidade e do CER para que o Cenário 3 tenha uma $\mathrm{TIR}=21 \%$.

Figura 40. Relação entre o preço da eletricidade e do CER para que o Cenário 4 tenha uma TIR $=21 \%$

Figura 41. Investimento inicial, Custo anual O\&M e VPL (TIR $=21 \%)$ nos diferentes cenários. 


\section{LISTA DE TABELAS}

Tabela 1. Indicadores utilizados. 26

Tabela 2. Características da usina média no Estado de São Paulo na safra 2009-2010. 27

Tabela 3. Parâmetros físico-químicos da vinhaça in natura resultante de três tipos de mostos diferentes.

Tabela 4. Caracterização físico-química da vinhaça obtida de levantamentos realizados no CTC.

Tabela 5. Sistemas de aplicação de vinhaça nas lavouras de cana-de-açúcar do Estado de São Paulo 36

Tabela 6. Propriedades físicas da vinhaça in natura e concentrada. .................................... 37

Tabela 7. Consumo de vapor por diferentes modelos de evaporadores.............................. 40

Tabela 8. Concentradores de vinhaça instalados. ......................................................... 42

Tabela 9. Taxa de aplicação das diferentes tecnologias para a digestão de vinhaça. .............. 46

Tabela 10. Características físico-químicas da vinhaça biodigerida - Usina São Martinho..... 46

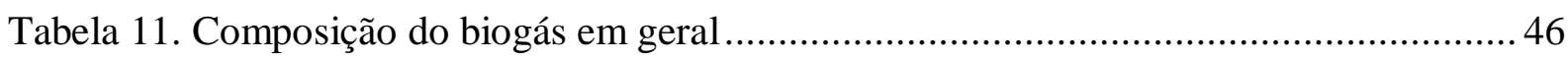

Tabela 12. Parâmetros da vinhaça concentrada............................................................. 54

Tabela 13. Sistemas instalados de combustão de vinhaça no Brasil. ................................... 59

Tabela 14. Consumo de combustíveis na maquinaria empregada para fertirrigação. ............. 68

Tabela 15. Quantidade de água a evaporar por $\mathrm{m}^{3}$ de $\mathrm{V}_{4^{\circ} \mathrm{Bx}}$ para atingir diferentes graus de

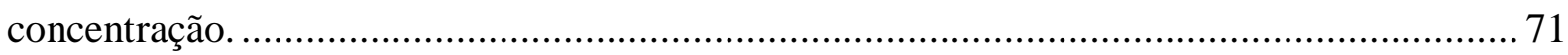

Tabela 16. Parâmetros termodinâmicos do ciclo de cogeração do Cenário 1 ......................... 72

Tabela 17. Consumo de diesel na fertirrigação com vinhaça concentrada e in natura. .......... 74

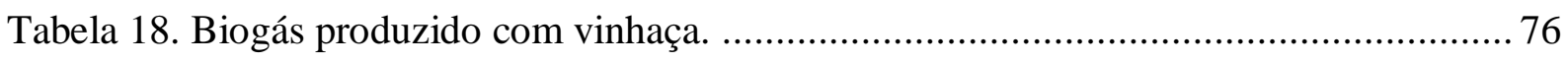

Tabela 19. Parâmetros da Planta de Biodigestão de São Martinho...................................... 76

Tabela 20. Balanço energético em cada cenário para uma usina média $\left(960.000 \mathrm{~m}^{3} \mathrm{de}\right.$

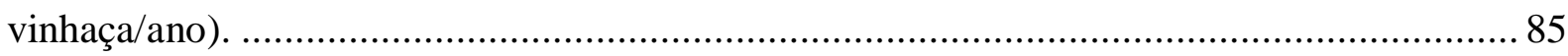

Tabela 21. Tipos de antibióticos utilizados na fabricação do etanol ..................................... 91

Tabela 22. Composição da vinhaça $\mathrm{kg} / \mathrm{m}^{3}$ em diferentes secções do canal. ........................... 98

Tabela 23. Composição da vinhaça $\mathrm{kg} / \mathrm{m}^{3} \mathrm{em}$ diferentes secções do canal ajustando a diluição.

Tabela 24. Carbono eliminado da vinhaça e emitido na forma de $\mathrm{CH}_{4}$ em lagoas e canais. . 100

Tabela 25. Cálculo das emissões de $\mathrm{NO}_{\mathrm{x}}$ no Cenário 0 de referência. .................................. 106

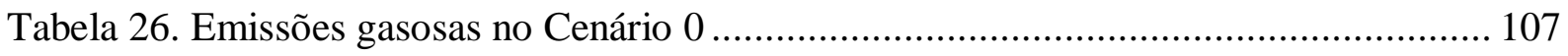


Tabela 27. Calculo das emissões de $\mathrm{NO}_{\mathrm{x}}$ no Cenário 1. 107

Tabela 28. Emissão de $\mathrm{NO}_{\mathrm{x}}$ e $\mathrm{SO}_{\mathrm{x}}$ da geração elétrica do Brasil. ....................................... 108

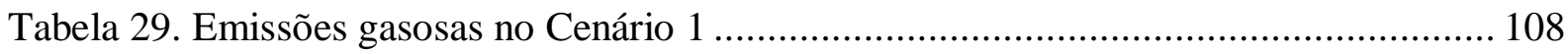

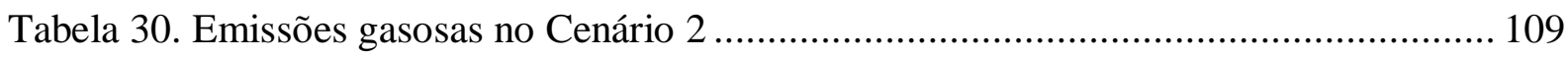

Tabela 31. Emissão de $\mathrm{NO}_{\mathrm{x}}$ e $\mathrm{SO}_{\mathrm{x}}$ do incinerador de vinhaça......................................... 110

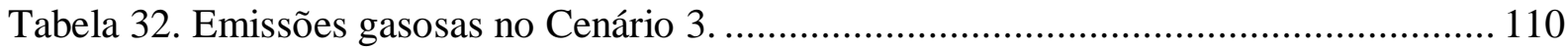

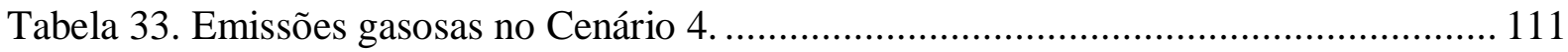

Tabela 34. Potenciais impactos dos Cenários sobre o solo e a água. .................................. 112

Tabela 35. Emissões atmosféricas associadas aos Cenários. ............................................... 113

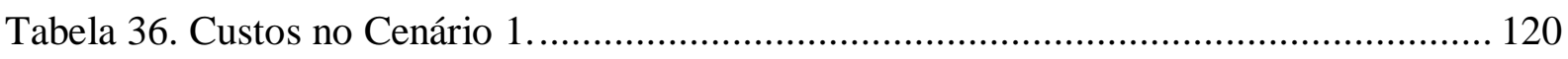

Tabela 37. Indicadores financeiros do investimento no Cenário 1 ....................................... 120

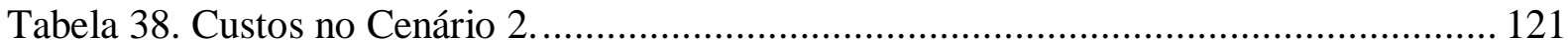

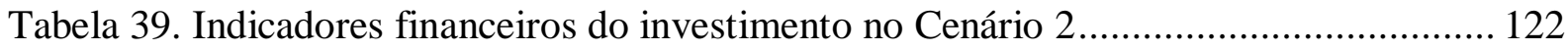

Tabela 40. Custo de produção da eletricidade gerada com biogás de vinhaça...................... 122

Tabela 41. Variação dos indicadores financeiros no Cenário 2 em função do preço da

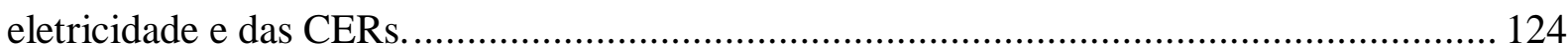

Tabela 42. Custo de instalação de pequenas centrais de biomassa..................................... 125

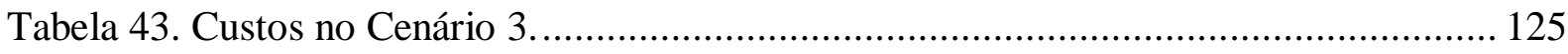

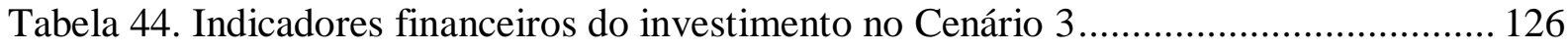

Tabela 45. Variação dos indicadores financeiros no Cenário 3 em função do preço da

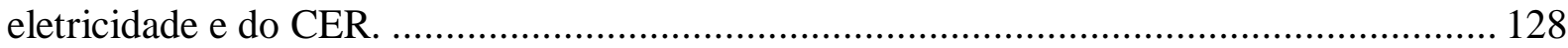

Tabela 46. Custos no Cenário 4 sem concentração. ............................................................... 129

Tabela 47. Custos no Cenário 4 com concentração......................................................... 130

Tabela 48. Custo de produção do litro diesel equivalente no cenário 3 .............................. 130

Tabela 49. Variação dos indicadores financeiros no Cenário 4 em função do preço do diesel e

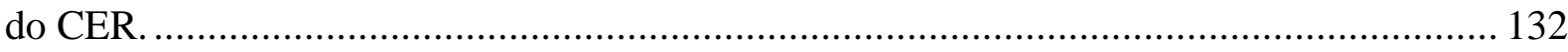

Tabela 50. Resultados da avaliação econômica............................................................... 133

Tabela 51. Volume estequiométrico de gases de exaustão da combustão de vinhaça $65^{\circ} \mathrm{Bx} .157$ Tabela 52. Composição mássica e volumétrica em base seca e úmida dos produtos da

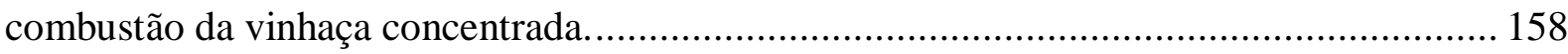

Tabela 53. Volume estequiométrico de gases de exaustão da combustão de gás natural ...... 159 Tabela 54. Composição mássica e volumétrica em base seca e úmida dos produtos da combustão gás natural. 


\section{LISTA DE SIGLAS}

ABNT - Associação Brasileira de Normas Técnicas

ANA - Agencia Nacional de Águas

ANEEL - Agência Nacional de Energia Elétrica

ANP - Agencia Nacional do Petróleo, Gás Natural e Biocombustíveis

APP - Área de proteção permanente.

BEN - Balanço Energético Nacional

BNDES - Banco Nacional do Desenvolvimento

CER - Certificate Emission Reduction

CETESB - Companhia de Tecnologia de Saneamento Ambiental

CGEE - Centro de Gestão de Estudos Estratégicos

CIP - Clean-in-Place

CNI - Confederação Nacional de Indústria

CONAB - Companhia Nacional de Abastecimento

CONAMA - Conselho Nacional do Meio Ambiente

COPAM - Conselho de Política Ambiental

CPFL - Companhia Paulista de Força e Luz

CTC - Capacidade de Troca Catiônica

CTC - Centro de Tecnologia Canavieira

DBO - Demanda Biológica do Oxigênio

DQO - Demanda Química de Oxigênio

EISA - Energetic Independence Security Act

EUA - Estados Unidos de America

GEEs - Gases de Efeito Estufa

GN - Gás Natural

GNV - Gás Natural Veicular

ICGEB - Intensidade de Carbono na Geração Elétrica Brasileira

IPT - Instituto de Pesquisas Tecnológicas

O\&M - Operação e manutenção

PCI - Poder Calorífico Inferior

PCS - Poder Calorífico Superior

Proálcool - Programa Nacional do Álcool

PROINFA - Programa de Incentivo às Fontes Alternativas de Energia Elétrica 
RED - Diretiva de Energias Renováveis

SIN - Sistema Interligado Nacional

TASTE - Thermally Accelerated Short Time Evaporator

TIR - Taxa Interna de Rendimento

UASB - Upflow Anaerobic Sludge Blanket

UNICA - União da Indústria da Cana-De-Açúcar

VPL - Valor Presente Liquido 


\section{LISTA DE SÍMBOLOS}

$\%$ - porcentagem

$€-$ Euros

$\mathrm{CH}_{4}-$ Metano

$\mathrm{CO}_{2}$ - Dióxido de Carbono

$\mathrm{CO}_{2} \mathrm{eq}$ - dióxido de carbono equivalente

$\mathrm{cP}-$ Centipoise

$\mathrm{g}$ - gamas

$\mathrm{G}-$ Giga

$\mathrm{h}$ - horas

$\mathrm{H}_{2} \mathrm{SO}_{4}$ - Ácido Sulfúrico

ha - Hectare

HP - Horse Power

J - Julio

$\mathrm{k}-$ Kilo

K - Potássio

1- Litros

M - Mega

$\mathrm{m}-$ Metro

$\mathrm{m}^{3}$ - Metros cúbicos

$\mathrm{NO}_{\mathrm{x}}-$ Óxidos de nitrogênios

${ }^{\circ} \mathrm{Bx}$ - Graus Brix

${ }^{\circ} \mathrm{C}$ - Grau Celsius

$\mathrm{R} \$$ - Reais

$\mathrm{SO}_{\mathrm{x}}$ - Óxidos de enxofre

$\mathrm{T}-$ Tera

$\mathrm{t}$ - Tonelada

W -Watt

$\mathrm{W}_{\mathrm{e}}-$ Watt elétrico

Wh - Watt hora

$\mathrm{W}_{\mathrm{t}}-$ Watt térmico 


\section{SUMÁRIO}

CAPÍTULO 1. INTRODUÇÃO, OBJETIVO E METODOLOGIA ............................... 19

1.1. Introdução ..................................................................................................................... 19

1.2. Objetivo e Metodologia ................................................................................................. 24

CAPÍTULO 2. ESTADO DA ARTE DOS TRATAMENTOS DA VINHAÇA.............. 28

2.1. Produção e características da vinhaça......................................................................... 28

2.2. Fertirrigação com vinhaça .....................................................................................32

2.3. Concentração da vinhaça ...........................................................................................37

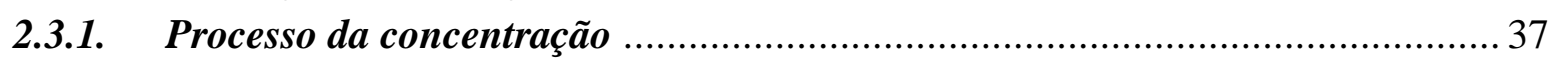

2.3.2. Implantação da tecnologia e estudos de caso ................................................... 41

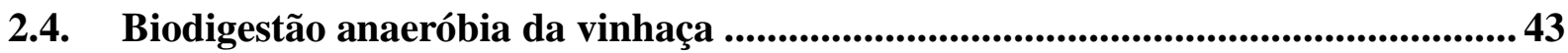

2.4.1. Processo da biodigestão

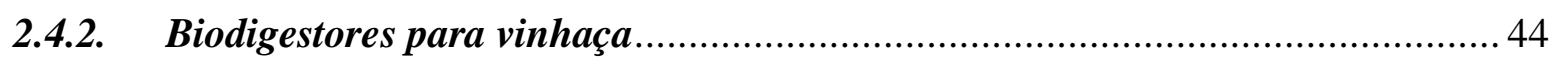

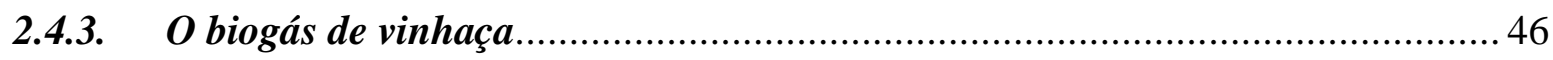

2.4.4. Limpeza, compressão e armazenamento de biogás ……………....................... 47

2.4.5. Tecnologias de conversão energética do biogás ................................................ 48

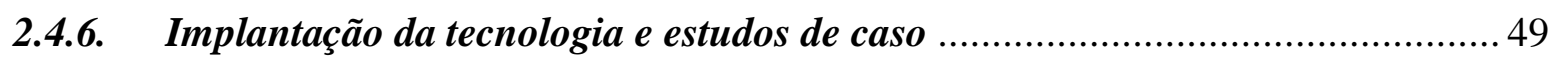

2.5. Combustão da vinhaça ............................................................................................54

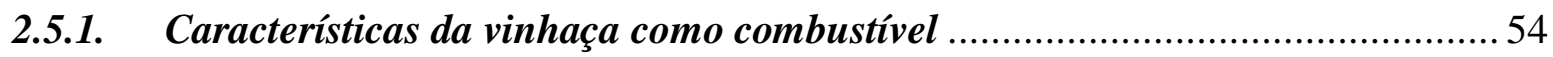

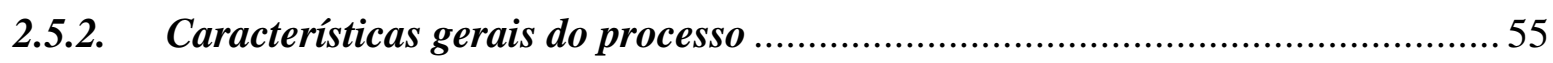

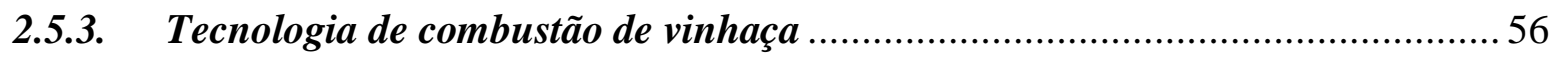

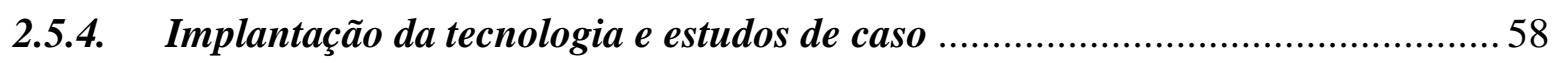

2.6. Resultados da revisão do estado da arte dos tratamento da vinhaça. ...................... 60

CAPÍTULO 3. DESCRIÇÃO DOS CENÁRIOS A SEREM ANALISADOS PARA TRATAMENTO DA VINHAÇA E SEU BALANÇO ENERGÉTICO. .............................. 61

3.1. Descrição dos cenários..................................................................................................61

3.1.1. Cenário 0 de referência: Fertirrigação com vinhaça in natura .......................... 61

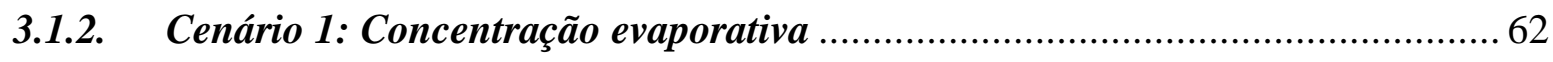

3.1.3. Cenário 2: Biodigestão anaeróbia com geração de eletricidade ......................... 63

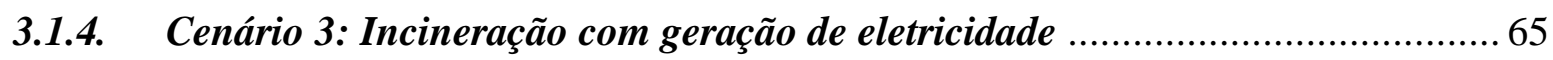

3.1.5. Cenário 4: Biodigestão com concentração e uso veicular ................................... 66

3.2. Balanço Energético de cada Cenário ...........................................................................6 67

3.2.1. Cenário 0 de referência: Fertirrigação com vinhaça in natura ..........................67

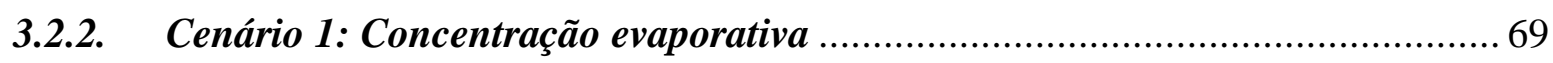

3.2.3. Cenário 2: Biodigestão anaeróbia com geração de eletricidade ………............. 75

3.2.4. Cenário 3: Incineração com geração de eletricidade ……………………........ 78

3.2.5. Cenário 4: Biodigestão com concentração e uso veicular .................................. 82

3.3. Resultados do balanço energético dos cenários considerados.....................................84 


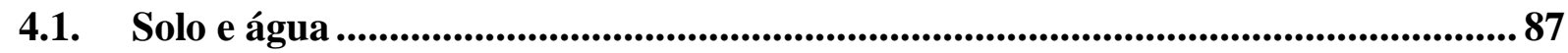

4.1.1. Cenário 0 de referência: Fertirrigação com vinhaça in natura ......................... 87

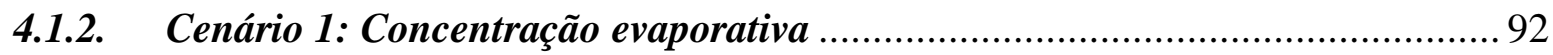

4.1.3. Cenário 2: Biodigestão anaeróbia com geração de eletricidade ....................... 93

4.1.4. Cenário 3: Incineração com geração de eletricidade ......................................... 94

4.1.5. Cenário 4: Biodigestão com concentração e uso veicular ................................ 95

4.2. Emissões de GEEs ..................................................................................................95

4.2.1. Cenário 0 de referência: Fertirrigação com vinhaça in natura ........................ 97

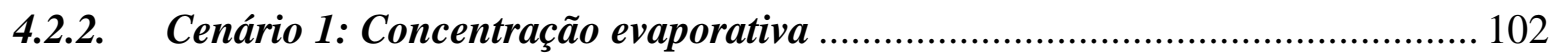

4.2.3. Cenário 2: Biodigestão anaeróbia com geração de eletricidade ...................... 103

4.2.4. Cenário 3: Incineração com geração de eletricidade ...................................... 104

4.2.5. Cenário 4: Biodigestão com concentração e uso veicular .............................. 104

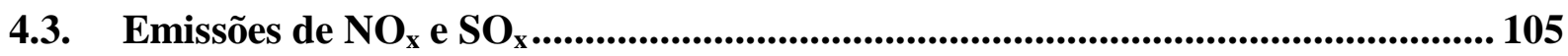

4.3.1. Cenário 0 de referência: Fertirrigação com vinhaça in natura ....................... 105

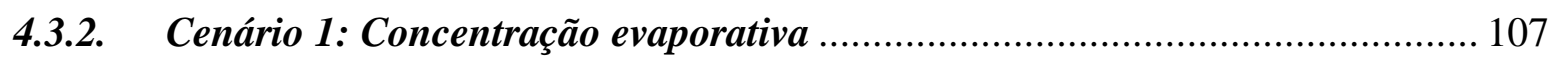

4.3.3. Cenário 2: Biodigestão anaeróbia com geração de eletricidade ....................... 108

4.3.4. Cenário 3: Incineração com geração de eletricidade ..................................... 109

4.3.5. Cenário 4: Biodigestão com concentração e uso veicular ............................. 111

4.4. Resultados da avaliação de impacto ambiental dos cenários considerados ........ 111

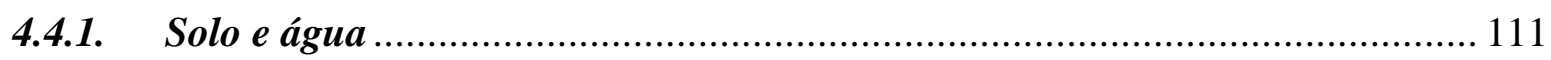

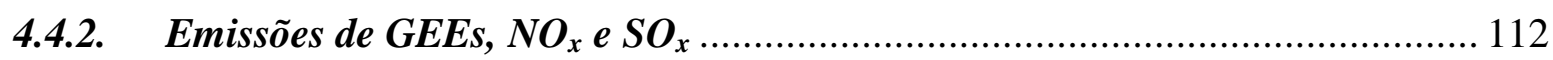

CAPÍTULO 5. AVALIAÇÃO ECONÔMICA .............................................................. 117

5.1. Cenário 0 de referência: Fertirrigação com vinhaça in natura .......................... 118

5.2. Cenário 1: Concentração evaporativa ................................................................... 119

5.3. Cenário 2: Biodigestão anaeróbia com geração de eletricidade .......................... 121

5.4. Cenário 3: Incineração com geração de eletricidade ........................................ 125

5.5. Cenário 4: Biodigestão com concentração e uso veicular .................................. 128

5.6. Resultados da avaliação econômica ..................................................................... 132

CAPÍTULO 6. RESULTADOS E DISCUSSÃO .................................................... 136

6.1. Cenário 0 de referência: Fertirrigação com vinhaça in natura ............................ 136

6.2. Cenário 1: Concentração evaporativa ........................................................... 138

6.3. Cenário 2: Biodigestão anaeróbia com geração de eletricidade .......................... 139

6.4. Cenário 3: Incineração com geração de eletricidade ....................................... 141

6.5. Cenário 4: Biodigestão com concentração e uso veicular .................................. 142

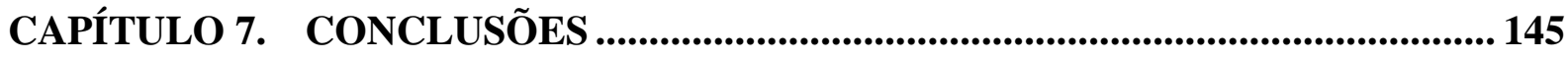

REFERÊNCIAS BIBLIOGRAFICAS ........................................................................... 148 
APÊNDICE A - CÁLCULO DO VOLUME DE EXAUSTÃo PARA CALDEIRAS QUEIMANDO VINHAÇA CONCENTRADA E GÁS NATURAL.................................... 157 


\section{CAPÍTULO 1. INTRODUÇÃO, OBJETIVO E METODOLOGIA}

\subsection{Introdução}

O Brasil pode ser considerado um caso especial em termos de quota de energias renováveis na sua matriz energética, devido à geração majoritária de eletricidade utilizando energia hidráulica e às iniciativas brasileiras relacionadas a biocombustíveis que têm sido intensamente implementadas desde 1975. A partir desse momento, foram introduzidas no país políticas públicas destinadas a promover a produção e o consumo de biocombustíveis em larga escala para reduzir a dependência externa do petróleo importado. Desde então, várias experiências transformaram o Brasil em líder mundial em bioenergia, fundamentalmente devido à produção, distribuição e utilização de etanol de cana-de-açúcar no setor de transportes.

A cana-de-açúcar é originária da Ásia e começou a ser plantada no Brasil pelos portugueses em 1532. No começo, as plantações prosperaram principalmente no Nordeste do país, tendo sido o principal produto brasileiro nos séculos XVI e XVII. A cana-de-açúcar é um cultivo próprio de regiões tropicais, pois necessita de grande quantidade de insolação para seu desenvolvimento. As terras adequadas para o cultivo são as mais férteis, mas também evolui de forma satisfatória em territórios menos fecundos, tais como o cerrado (BNDES, 2008).

No Brasil, o ciclo da cana-de-açúcar é geralmente de seis anos, ocorrendo cinco cortes, sendo que o primeiro deles é feito 12 ou 18 meses após o plantio, quando é colhida a chamada cana-planta. Depois de realizado este primeiro corte, produz-se o rebrote que é chamado de cana-soca. Então, é feito um corte por ano ao longo de quatro safras consecutivas com uma redução gradual da produtividade. Depois de realizado o quinto corte, substitui-se a cana antiga por um novo plantio, o que reinicia o ciclo produtivo. Para melhorar a fertilidade do solo, a área cultivada fica alguns meses em descanso, inclusive sendo cultivadas leguminosas fixadoras de nitrogênio.

No ano 2014, o Brasil era líder mundial na produção de cana-de-açúcar e na fabricação de etanol a partir desta matéria prima, processando cerca de 600 milhões de toneladas em cada safra, das quais aproximadamente a metade é utilizada para produzir 25 milhões de $\mathrm{m}^{3}$ do combustível. A maior parte dos canaviais se localiza no interior do Estado de São Paulo 
( $60 \%$ da área plantada), com a produção mais importante na região de Ribeirão Preto (UNICA, 2013).

O etanol é um combustível líquido utilizado principalmente nos motores de explosão ciclo Otto. Com a crise do petróleo da década de 1970, o etanol converteu-se em produto estratégico para o Brasil. Em 1975 foi instituído o Programa Nacional do Álcool (Proálcool), cujo objetivo era diminuir as importações de petróleo expandindo a produção e o uso energético do etanol. Nos anos 1980, o governo investiu em usinas, destilarias e fábricas de automóveis para realizar esta expansão (GOLDEMBERG et al., 2003). Um incentivo importante do Proálcool consistiu no estabelecimento de níveis mais significativos no teor de etanol anidro na gasolina até atingir $25 \%$. Por outro lado, o governo regulou que o preço do etanol hidratado deveria ser menor do que o da gasolina. Estabeleceu-se também a abertura de linhas de crédito favoráveis para que os usineiros incrementassem sua capacidade de produção.

Quanto ao setor automobilístico, incentivou-se por meio da redução de impostos a venda de carros exclusivamente movidos a álcool (E100 $\left.{ }^{1}\right)$. Todos estes incentivos tiveram como resultado o incremento na produção de etanol no inicio da década de 80.

Durante o ano de 1985, os preços do petróleo caíram e houve uma recuperação dos preços do açúcar, e em 1986 o governo federal reduziu os incentivos para a agroindústria canavieira dando lugar ao que se chamou de crise do álcool. Em 1989 aconteceram descontinuidades no abastecimento de etanol, afetando seriamente a confiança do consumidor, o que provocou a queda nas vendas dos carros E100. O ponto de inflexão nessa queda não chegou até 2003, quando houve o lançamento dos veículos flexíveis e, em consequência, o consumo de etanol hidratado voltou a crescer.

A produção deste combustível cresceu de 0,6 milhões de $\mathrm{m}^{3}$ no ano de 1975 (GOLDEMBERG et al., 2003) até superar os 27 milhões de $\mathrm{m}^{3}$ no ano 2009 (UNICA, 2013). Nos dias de hoje, o etanol é usado no Brasil como um aditivo para gasolina, cuja mistura é chamada "gasohol" com uma proporção de 20\% (E20) a 26\% (E26) de etanol anidro. Por outro lado, o etanol hidratado é dedicado a veículos flex que funcionam com qualquer proporção de gasolina e etanol, até E100.

Em 2010, o etanol substituiu 44,6\% da gasolina no Brasil, quando nos Estados Unidos de America (EUA) esta porcentagem só chegava a 9,5\% (DATAGRO, 2012). A meta definida em 2007 nos EUA pelo Energetic Independence Security Act (EISA) foi alcançar a

\footnotetext{
${ }^{1}$ A nomenclatura E100 refere-se a proporção de etanol no combustível, neste caso $100 \%$ de etanol. No caso de E20 seria $20 \%$ de etanol.
} 
substituição de $20 \%$ de todos os combustíveis de transporte até 2022 (EUA, 2007). A Diretiva de Energias Renováveis (RED), emitida pela Comissão Europeia, estabeleceu a meta de substituir $10 \%$ de todos os combustíveis de transporte com combustíveis renováveis na Europa até 2020 (EU, 2009). Em 2010, a proporção real de etanol e biodiesel no consumo de combustíveis na Europa foi de apenas 3,4\% (DATAGRO, 2012).

O Brasil tem um desempenho notável no rendimento agroindustrial medido em termos de litros de etanol hidratado produzido por hectare. Este rendimento era de 4.450 litros de etanol hidratado por hectare na fase inicial do Proálcool (1977-78), mas até o ano 2014 tem evoluído para 6.800 litros de hidratado equivalente de etanol por hectare (CGEE, 2005). O rendimento agrícola médio, medido em toneladas de cana por hectare, no período de 2005 até 2009 foi de 85,5 t/ha na região Centro-Sul (DATAGRO, 2012), sendo esta a mais produtiva. No entanto, devido às secas severas em 2010 e em 2011, bem como ao envelhecimento dos canaviais causados por uma taxa mais baixa do que o normal de renovações, o rendimento agrícola médio caiu para 67 t/ha em 2011 (DATAGRO, 2012).

$\mathrm{Na}$ fabricação do etanol as etapas iniciais (até a filtração) são basicamente as mesmas da produção de açúcar. Após o corte da cana é fundamental o transporte o mais rápido possível para sua moagem na usina, evitando perdas de sacarose, sendo prejudicial seu armazenamento. Este fato obriga às usinas a operarem apenas durante o período da safra. Quando a cana chega à usina é limpa antes de ser extraído o caldo por moenda ou difusão. Nos rolos utilizados para a moenda, o caldo rico em sacarose é separado da fibra, chamada de bagaço. Outra opção para a extração do caldo é a difusão, que consiste em lavar sucessivamente com água quente a cana picada e desfibrada. Em qualquer um dos dois casos, o caldo obtido é destinado à produção de açúcar ou etanol.

No caso da produção de açúcar, o caldo é tratado quimicamente e filtrado para a eliminação de impurezas, gerando um resíduo chamado de torta de filtro, que é aproveitado como adubo na plantação de cana. O caldo purificado é concentrado em evaporadores e cozedores, sendo posteriormente centrifugado para conseguir a cristalização da sacarose. Desta etapa se obtém outro resíduo chamado de melaço, uma solução que contém um elevado teor de açúcares, podendo ser utilizado como matéria-prima para a produção do etanol mediante fermentação.

Desta forma, a produção de etanol de cana-de-açúcar pode vir tanto da fermentação do caldo quanto de misturas de caldo e melaço. A este caldo, chamado de mosto, é adicionado leveduras, fungos unicelulares da espécie Saccharomyces cerevisae, para ser fermentado, 
dando origem ao vinho que possui uma concentração de $7 \%$ a $10 \%$ de etanol. Após a fermentação, as leveduras são recuperadas usualmente por centrifugação e tratadas para novo uso, enquanto o vinho é enviado para as colunas de destilação. Na destilação, o etanol é recuperado em forma hidratada, com aproximadamente $96 \%$ de etanol em volume e $4 \%$ de água. O etanol hidratado pode ser o produto final ou ser desidratado pelos processos de destilação extrativa (usando metil-etileno glicol) ou utilizando uma peneira molecular (pelo processo de adsorção em colunas com um zeólito), obtendo o etanol anidro com aproximadamente 99,7\% de etanol em volume (BNDES, 2008).

Além do etanol, o bagaço de cana, que é o resíduo sólido da extração do caldo, é utilizado em sistemas de aquecimento e geração de energia combinados (cogeração) para fornecer energia térmica e eletromecânica dentro das usinas e vender o excedente de eletricidade para a rede comercial. Em junho de 2012, havia 352 sistemas de cogeração em usinas de açúcar e etanol no Brasil, registrados pela Agência Nacional de Energia Elétrica (ANEEL), com uma capacidade instalada total de 7.588 MW (ANEEL, 2012).

A vinhaça é o principal subproduto da produção de etanol, resultante da destilação do vinho, que é o resultado da fermentação do caldo da cana-de-açúcar ou do melaço no processo de fabricação deste álcool. As destilarias brasileiras produzem entre 7 a 15 litros de vinhaça por litro de etanol dependendo do porte da instalação e tecnologia empregada, sendo as menores e mais antigas as que apresentam maior geração de resíduo (SALOMON, 2007).

O uso da vinhaça para fertirrigar os canaviais tem sido a solução empregada para destinar o enorme volume produzido. Assim, pode ser aproveitado seu importante conteúdo em potássio e outros nutrientes, o que incrementa a produção de cana por hectare e reduz o consumo de fertilizantes. Ao mesmo tempo evita seu descarte em corpos hídricos com os impactos ambientais decorrentes (COELHO et. al. 1986). Por outro lado, esta prática pode causar salinização do solo e contaminação de aquíferos subterrâneos. Vários autores (HASSUDA,1989, GLOEDEN et al., 1991, HIRATA et al., 1991, LYRA et al., 2003, SILVA et al., 2007, e outros) discutiram o risco da contaminação do lençol freático com a prática da fertirrigação com a vinhaça.

A aplicação sem critérios adequados de dosagem da vinhaça ao solo pode causar um desequilíbrio de nutrientes e gerar resultados diferentes dos esperados, pois a dosagem adequada varia segundo o tipo de solo e segundo as variedades de cana (GLÓRIA; ORLANDO FILHO, 1984). A partir do ano 2006, no Estado de São Paulo, a Companhia de Tecnologia de Saneamento Ambiental (CETESB) recomenda a aplicação de vinhaça no solo 
por meio da Norma P4.231, que inclui uma metodologia para determinação do volume máximo de vinhaça aplicado ao solo de acordo com as características físico-químicas deste (CETESB, 2006). O cumprimento dessa norma prevê a sobreacumulação de potássio nos solos e a contaminação do lençol freático. O problema da dispersão do potássio presente na vinhaça vem sendo contornado com o emprego de concentradores, os quais reduzem o volume de vinhaça e permitem ampliar o raio econômico de transporte.

Um assunto ainda inexplorado é a determinação do impacto que a fertirrigação promove com a dispersão no meio ambiente de antibióticos ativos presentes na vinhaça. Apesar da importância do impacto potencial da seleção de microrganismos resistentes a estes antibióticos, este problema tem sido pouco tratado pela pesquisa científica.

A fertirrigação com vinhaça possui um alto potencial para a emissão de metano $\left(\mathrm{CH}_{4}\right)$ e oxido nitroso $\left(\mathrm{N}_{2} \mathrm{O}\right)$, reconhecidos Gases de Efeito Estufa (GEEs). Essas emissões são produzidas porque a vinhaça é microbiologicamente ativa por seu importante conteúdo em matéria orgânica e nitrogênio. A decomposição da matéria orgânica em condições de anaerobiose ${ }^{2}$ emite $\mathrm{CH}_{4}$ durante o armazenamento e transporte da vinhaça. Ainda assim, o conhecimento dos efeitos da fertirrigação dos canaviais com relação a emissões de GEEs é escasso e não bem quantificado (LISBOA et al., 2011). Carmo et al., 2012, indicam que devem ser desenvolvidas melhores práticas de gestão para minimizar os efeitos negativos da aplicação de vinhaça sobre as emissões de GEEs. Como possível solução a estas emissões encontra-se a biodigestão anaeróbia da vinhaça que reduz significativamente a carga orgânica e possibilita a captura e o uso do biogás, mitigando as emissões de $\mathrm{CH}_{4}$ para a atmosfera.

Também se considera a possibilidade de incinerar a vinhaça, por permitir solucionar os problemas importantes de sua disposição. Por um lado, elimina-se o enorme volume e os problemas atrelados a seu transporte; e por outro, a elevada carga orgânica é aproveitada para a geração de energia térmica e elétrica. Com a incineração, são evitadas tanto as emissões de $\mathrm{CH}_{4}$ como as que são produzidas no transporte da vinhaça provenientes do diesel. Como único resíduo sólido remanescente obtêm-se as cinzas com grande concentração de potássio, utilizáveis como fertilizante.

Outra possibilidade é integrar a biodigestão anaeróbia com a posterior concentração, para utilizar o biogás como substituto de diesel na frota da usina ou para fornecer parte da energia necessária na concentração da vinhaça.

\footnotetext{
${ }^{2} \mathrm{O}$ termo anaerobiose faz referência a reações metabólicas na ausência de oxigênio. Determinados microrganismos são capazes de realizar suas funções nessas condições, como por exemplo, as Arqueas metanogênicas.
} 
Em definitivo, a valorização energética da vinhaça, em um contexto de aumento da demanda e preço da energia e de uma crescente dependência de fontes não renováveis na matriz energética brasileira (MME, 2013), pode ser uma alternativa interessante. Neste contexto, este trabalho faz uma revisão de quais são os impactos ambientais atrelados a cada uma das tecnologias e discute as barreiras de implantação, com a tentativa de elucidar qual delas é a mais conveniente para sua implantação.

Esta dissertação é constituída por sete capítulos, sendo eles: 1.Introdução, Objetivos e Metodologia, 2.Estado da Arte dos Tratamentos da Vinhaça, 3.Descrição dos Cenários para o Tratamento da Vinhaça e seu Balanço Energético, 4.Avaliação de Impacto Ambiental, 5.Avaliação Econômica, 6.Resultados e Discussão, 7.Conclusões. A seguir será descrito cada um deles.

No Capítulo 1, encontra-se uma introdução geral sobre a dissertação com um resumo sobre a história da produção de etanol de cana-de-açúcar no Brasil e sua consequente geração de vinhaça, dando-se as justificativas para o trabalho. Por outro lado, são definidos os objetivos gerais e específicos deste estudo, assim como a metodologia seguida para atingi-los.

No Capítulo 2, faz-se uma revisão sobre o estado da arte dos tratamentos da vinhaça disponíveis utilizando fontes bibliográficas e dados levantados em entrevistas e visitas técnicas.

Os dados coletados são utilizados no Capítulo 3 para configurar uma série de cenários que representam as possíveis alternativas para o tratamento da vinhaça. Também no Capítulo 3, são calculados os balanços energéticos de cada cenário descrito, discriminando a forma de energia consumida e produzida.

O Capítulo 4 trata dos potenciais impactos de cada alternativa sobre a água, o solo e a atmosfera.

A viabilidade econômica da implantação de cada sistema de tratamento é avaliada no Capítulo 5.

O Capítulo 6 resume, analisa, compara e discute todos os resultados obtidos nos capítulos anteriores para, em seguida, extrair as conclusões, apresentadas no Capítulo 7.

\subsection{Objetivo e Metodologia}

O objetivo geral deste estudo é comparar as diferentes alternativas de processamento para o aproveitamento energético da vinhaça, na procura daquelas com maior viabilidade tecnológica, impactos ambientais reduzidos e que estejam associadas a um menor custo. Com 
isto, pretendesse auxiliar à indústria do etanol e aos formuladores de políticas ambientais e energéticas na escolha da melhor tecnologia disponível, através da comparação do desempenho ambiental e da avaliação técnico-econômica, ponderando também as barreiras encontradas na implantação. Este trabalho propõe como objetivos específicos:

1. Levantar o estado da arte de cada tecnologia de processamento da vinhaça, incluindo a escala atual de implantação e as barreiras encontradas para expandir seu uso.

2. Calcular o balanço energético no ciclo produtivo de cada alternativa.

3. Analisar os impactos ambientais de forma abrangente, abarcando os impactos locais no solo e na água, assim como impactos globais com emissões na atmosfera de GEEs.

4. Avaliar a viabilidade econômica das distintas opções, considerando os custos iniciais, de manutenção e operacionais de cada tecnologia, assim como os benefícios associados à produção de energia e fertilizante.

5. Validar ou refutar a hipótese de que existem tecnologias disponíveis e viáveis que melhoram o desempenho ambiental e o aproveitamento da vinhaça quando comparadas com seu uso atual na fertirrigação in natura.

Para atingir estes objetivos, são levantadas informações sobre a composição da vinhaça e o estado da arte dos seus possíveis tratamentos. Este levantamento foi realizado através de uma revisão bibliográfica e entrevistando os principais fornecedores de equipamentos para a concentração, biodigestão e incineração de vinhaça presentes no Brasil. Por outro lado, foram realizadas visitas técnicas a instalações industriais de biodigestão para o levantamento de dados primários.

Os dados obtidos na primeira fase foram utilizados para configurar cinco cenários correspondendo às alternativas tecnológicas para o processamento da vinhaça:

1. Fertirrigação com vinhaça in natura.

2. Concentração.

3. Biodigestão com produção de energia elétrica.

4. Incineração com produção de energia elétrica.

5. Biodigestão com concentração posterior e uso veicular do biogás.

Definidos os cenários, são calculados os balanços energéticos para as cinco alternativas propostas. Determinam-se quais são as quantidades de energia térmica e elétrica que é 
consumida e produzida por cada sistema de tratamento de vinhaça, assim como especificada a origem fóssil ou renovável dessa energia.

Posteriormente, os resultados obtidos no balanço energético são utilizados para estimar as emissões atmosféricas em cada cenário, aproximando qual seria a magnitude das emissões evitadas com a introdução das diferentes tecnologias. Além disso, outros impactos são considerados, como o consumo de água e salinização do solo.

Os resultados das etapas anteriores são valorados economicamente através do preço da energia e dos direitos de emissão para sua inclusão na análise econômica, junto com o investimento e custos de operação e manutenção atrelados a cada processo.

Finalmente, integra-se toda esta informação por meio de tabelas e gráficos que facilitem a comparação entre cenários e discutem-se os resultados.

Resumidamente, para cada um destes cenários são calculados diferentes indicadores quantitativos e qualitativos. Os indicadores avaliados são os apresentados na Tabela 1.

Tabela 1. Indicadores utilizados.

\section{Categoria de indicador \\ Indicador \\ Unidade de medida}

\begin{tabular}{|c|c|c|c|}
\hline \multirow{3}{*}{ Energético } & \multicolumn{2}{|c|}{ Balanço Elétrico } & GWh/ano \\
\hline & \multicolumn{2}{|c|}{ Balanço Térmico } & TWh/ano \\
\hline & \multicolumn{2}{|c|}{ Consumo de energia fóssil } & TWh/ano \\
\hline \multirow{3}{*}{ Ambiental } & \multicolumn{2}{|c|}{ Impactos no solo e água } & Qualitativo \\
\hline & \multirow{2}{*}{$\begin{array}{c}\text { Emissões } \\
\text { Atmosféricas }\end{array}$} & GEEs & teqCO $2 /$ ano \\
\hline & & $\mathrm{NO}_{\mathrm{x}}$ e $\mathrm{SO}_{\mathrm{x}}$ & $\mathrm{kg} / \mathrm{ano}$ \\
\hline \multirow{3}{*}{ Econômico } & \multicolumn{2}{|c|}{$\begin{array}{c}\text { Valor Presente Líquido } \\
\text { (VPL) }\end{array}$} & $\mathrm{R} \$$ \\
\hline & \multicolumn{2}{|c|}{$\begin{array}{c}\text { Taxa Interna de Retorno } \\
\text { (TIR) }\end{array}$} & $\%$ \\
\hline & \multicolumn{2}{|c|}{ Payback descontado } & Anos \\
\hline
\end{tabular}

Fonte: autor

Com a intenção de facilitar a comparação entre cenários e dar uma ordem de magnitude que permita o cálculo de indicadores quantitativos, é tomada como referência uma usina mista 
de produção de açúcar e álcool de características médias no Estado de São Paulo. Para a definição dos parâmetros desta Usina média foi consultado o relatório sobre o perfil do setor do açúcar e do álcool no Brasil (CONAB, 2012) referente à safra 2009-2010 (Tabela 2).

Tabela 2. Características da usina média no Estado de São Paulo na safra 2009-2010.

\begin{tabular}{ccc}
\hline Variável & Unidade & Magnitude \\
\hline Número de Usinas & Dias & 169 \\
Dias corridos de atividade na safra por unidade & $(\mathrm{t} / \mathrm{dia})$ & 8.867 \\
Média aritmética de moagem diária por unidade & $(\mathrm{t} / \mathrm{ano})$ & 2.145 .814 \\
Média aritmética de moagem anual por unidade & $(\mathrm{t} / \mathrm{ha})$ & 85,73 \\
Produtividade física & $\%$ & $53,9 \%$ \\
Percentual de cana destinada para álcool etílico & $(\mathrm{t} / \mathrm{ano})$ & 1.156 .594 \\
Quantidade de cana destinada para álcool etílico & $(\mathrm{l})$ & 76,3 \\
Quantidade de álcool etílico total por ton. de cana processada & $\left(\mathrm{m}^{3}\right)$ & 88.248 \\
Quantidade de álcool etílico total por ano & $(\mathrm{l})$ & 6.686 \\
Quantidade de álcool etílico total por hectare e cana colhida & $(1 / 1)$ & 10,85 \\
Produção de litros de vinhaça por litro de álcool etílico & $\left(\mathrm{m}^{3}\right)$ & 960.000 \\
\hline Quantidade de vinhaça por ano & &
\end{tabular}

Fonte: CONAB (2012).

Esta usina com características médias será utilizada como base para a criação de cenários no Capítulo 3, e consequentemente como referência para os cálculos realizados nos capítulos 5 e 6 . 


\section{CAPÍTULO 2. ESTADO DA ARTE DOS TRATAMENTOS DA VINHAÇA}

\subsection{Produção e características da vinhaça}

A vinhaça é um subproduto proveniente da destilação de uma dissolução alcoólica chamada "vinho". O vinho é o produto da fermentação alcoólica do caldo de cana, do melaço ou da mistura de ambos em distintas proporções (Figura 1). Segundo a região, a vinhaça recebe diferentes nomes, tais como vinhoto, restilo ou garapão (ELIA NETO, 2014). Este efluente das destilarias esta constituído principalmente por água, sais, sólidos em suspensão, solúveis e quantidades importantes de Demanda Química de Oxigênio (DQO) e Demanda Biologica de Oxigênio (DBO), o que produz mau cheiro com a putrefação da matéria orgânica (CETESB, 1982). Esta suspensão aquosa tem características muito variáveis dependendo da matéria-prima, do solo, do clima e do processo industrial empregado para a produção de etanol, assim como da mistura de melaço e caldo utilizada na fermentação.

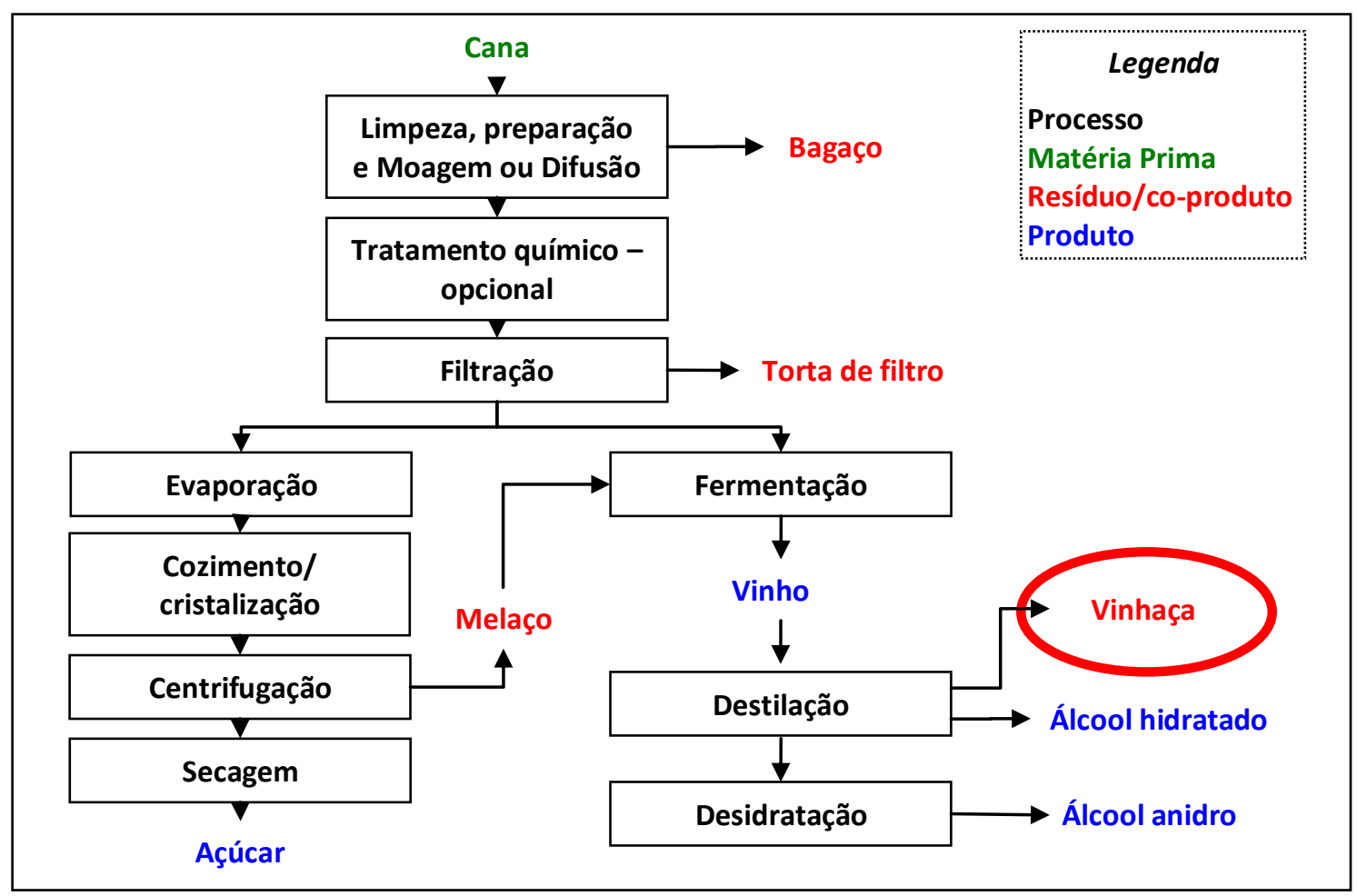

Figura 1. Fluxograma do processo.

Fonte: Adaptado de Seabra (2008).

A quantidade de vinhaça produzida por litro de etanol varia entre 7 e 15 litros. De forma geral, em usinas implantadas recentemente obtém-se uma média de 7 a 10 litros de vinhaça por litro de etanol, entretanto em usinas antigas registra-se uma média de 10 a 15 litros de vinhaça por litro de etanol (SALOMON, 2007). Este volume depende basicamente do teor 
alcoólico do vinho e do emprego de vapor direto $^{3}$ para aquecer o caldo. Sem o uso vapor direto e com fermentação de grau alcoólico acima de $12^{\circ} \mathrm{GL}$ tem-se uma relação próxima a 7 litros de vinhaça/litro de álcool. No outro extremo, quando existe incorporação de vapor e fermentação de baixo grau alcoólico se obtém até 15 litros (ELIA NETO \& NAKAHODO, 1995). Com um valor médio de referência 10,85 litros de vinhaça por litro de etanol (ELIA NETO e NAKAHODO, 1995) e os dados de produção nacional de etanol (UNICA, 2013), pode calcular-se a produção de vinhaça no Brasil (Figura 1), que resulta ser de aproximadamente 250 milhões de $\mathrm{m}^{3}$ de vinhaça por ano nas últimas safras.

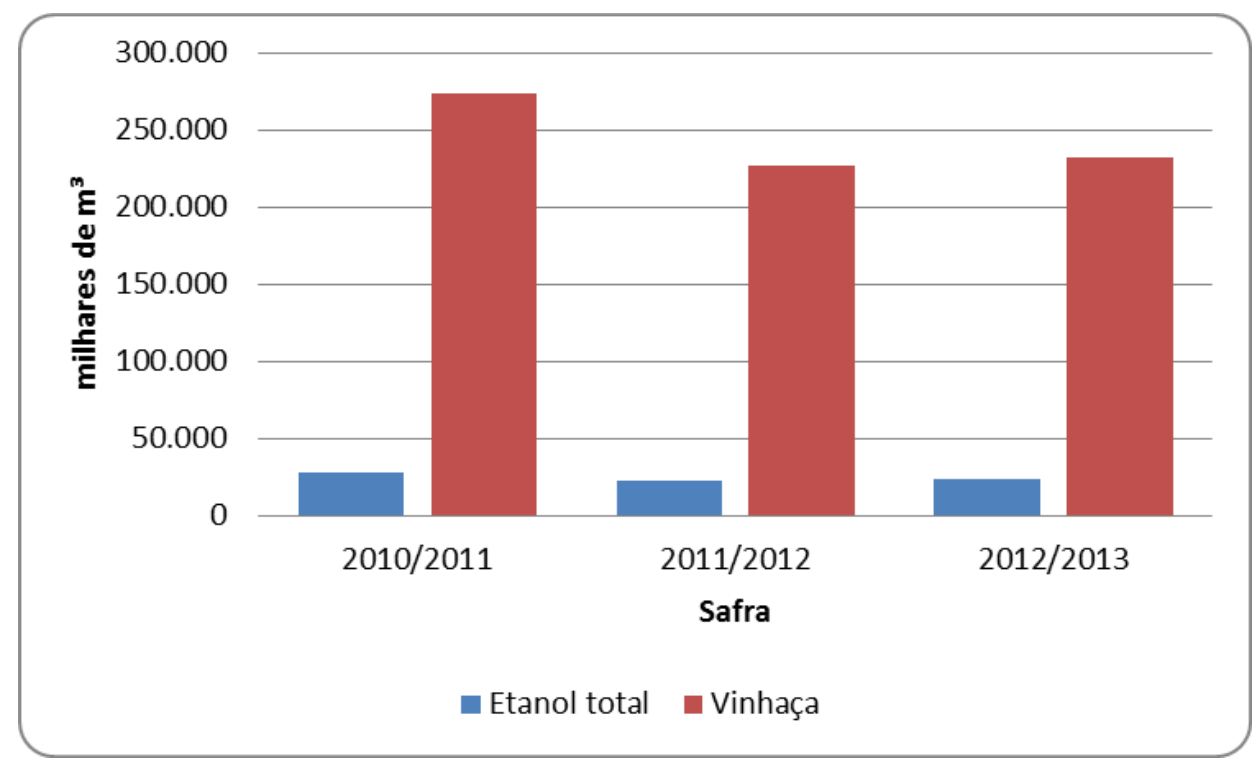

Figura 2. Produção estimada de vinhaça no Brasil. Fonte de dados: UNICA (2013).

Segundo Ludovice (1997), a vinhaça possui uma coloração parda (Figura 3), escurecendo-se à medida que é oxidada pela exposição ao ar. Com a putrefação da matéria orgânica ganha turbidez e intensifica-se seu mau cheiro característico devido ao conteúdo em enxofre que permite a formação de $\operatorname{mercaptanos}^{4}$ (ELIA NETO, 2014). A vinhaça é extraída no processo de destilação a uma temperatura que varia de 85 a $90{ }^{\circ} \mathrm{C}$ quando não há reaproveitamento regenerativo do seu calor (ROSSETTO, 1987). Devido à utilização de ácido sulfúrico $\left(\mathrm{H}_{2} \mathrm{SO}_{4}\right)$ nas dornas de fermentação o efluente possui características ácidas, com $\mathrm{pH}$ variando entre 3,5 e 5 (CETESB, 1982; ANA, 2009), o que a torna corrosiva. A variabilidade nas características de esta suspensão aquosa pode ser observada na Tabela 3 e Tabela 4. Apresenta uma importante quantidade de matéria orgânica biodegradável, com elevada DBO

\footnotetext{
${ }^{3}$ No aquecimento direto, o vapor entra em contato com o caldo e, com sua condensação, aumenta o volume da água nas dornas.

${ }^{4}$ São denominados como mercaptanos os compostos orgânicos que contem o grupo -SH.
} 
e nitrogênio, o que a torna biologicamente ativa. Também possui uma elevada condutividade elétrica devido ao alto conteúdo de sais, sobretudo de potássio.

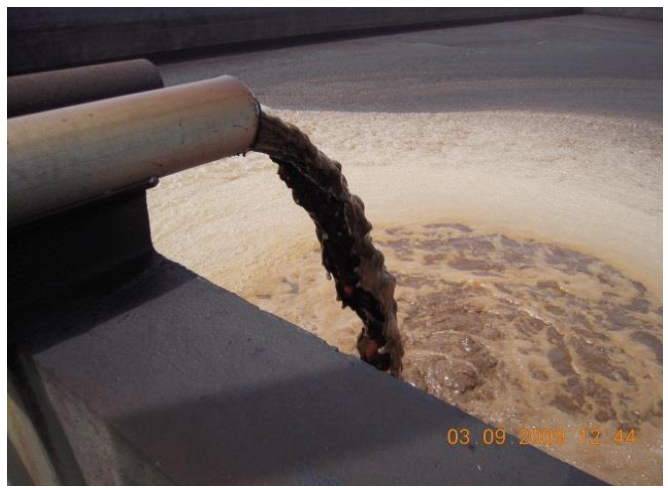

Figura 3. Vinhaça.

Fonte: Elia Neto (2014).

$\mathrm{Na}$ literatura são encontradas poucas informações sobre a caracterização da vinhaça, sendo muito referenciado o trabalho "Utilização de Restilo como Fertilizante em Solo Cultivado com Cana de Açúcar - Relatório Final", (CETESB, 1982) que agrupa dados de vinhaça obtidos por vários pesquisadores, desde o ano de 1952. Este trabalho apresenta largos intervalos de variabilidade procedentes de mostos de melaço, caldo e misto (Tabela 3).

Tabela 3. Parâmetros físico-químicos da vinhaça in natura resultante de três tipos de mostos diferentes.

\begin{tabular}{lccc}
\hline \multicolumn{1}{c}{ Parâmetro } & Melaço & Caldo & Misto \\
\hline $\mathrm{pH}$ & $4,2-5,0$ & $3,7-4,6$ & $4,4-4,6$ \\
$\mathrm{DBO} \mathrm{mg} / \mathrm{l}$ & 25.000 & $6.000-16.500$ & 19.100 \\
$\mathrm{DQO} \mathrm{mg} / \mathrm{l}$ & 65.000 & $15.000-33.000$ & 45.000 \\
Sólidos Totais mg/l & 81.500 & 23.700 & 52.700 \\
Sólidos Fixos mg/l & 21.500 & 3.700 & 12.700 \\
Nitrogênio mg/l & $450-1.600$ & $150-700$ & $480-710$ \\
Fósforo mg/l $\mathrm{P}_{2} \mathrm{O}_{5}$ & $100-290$ & $10-210$ & $9-200$ \\
Potássio mg/l $\mathrm{K}_{2} \mathrm{O}$ & $3.740-7.830$ & $1.200-2.100$ & $3.340-4.600$ \\
Cálcio mg/l CaO & $450-5.180$ & $130-1.540$ & $1.330-4.570$ \\
Magnésio mg/l MgO & $420-1.520$ & $200-490$ & $580-700$ \\
Sulfato mg/l SO ${ }_{4}^{-2}$ & 6.400 & $600-760$ & $3.700-3.730$ \\
Carbono mg/l C & $11.200-22.900$ & $5.700-13.400$ & $8.700-12.100$ \\
Relação C/N & $16-16,27$ & $19,70-21,07$ & $16,40-16,43$ \\
Matéria Orgânica mg/l & 63.400 & 19.500 & 38.000 \\
Substâncias redutoras mg/l & 9.500 & 7.900 & 8.300 \\
\hline
\end{tabular}

Fonte: CETESB (1982).

Outras caracterizações de referencia mais recentes são as obtidas em dois levantamentos realizados pelo Centro de Tecnologia Canavieira (CTC), o primeiro em 1995 (ELIA NETO \& NAKAHODO, 1995) e o segundo em 2007 (ELIA NETO \& ZOTELLI, 2008), onde são apresentadas as médias e os resultados extremos (Tabela 4). A composição e características da 
vinhaça tem sofrido uma evolução temporal, consequência do progresso na tecnologia empregada na fabricação do etanol. Pode ser observado que a vinhaça atual é mais concentrada, tendo maior teor de sólidos e matéria orgânica que no passado, sendo esta uma consequência da evolução tecnológica das usinas.

Tabela 4. Caracterização físico-química da vinhaça obtida de levantamentos realizados no CTC.

\begin{tabular}{|c|c|c|c|c|c|}
\hline \multirow[t]{2}{*}{ Descrição } & \multirow[t]{2}{*}{ Uni. } & \multicolumn{2}{|c|}{ Valores Médios } & \multicolumn{2}{|c|}{ Valores extremos } \\
\hline & & CTC, $1995(* 1)$ & CTC, $2007(* 2)$ & Mínimo & Máximo \\
\hline Alumínio & $\mathrm{mg} / \mathrm{L}$ & - & 18,30 & $<5,0$ & 120,0 \\
\hline Bário & $\mathrm{mg} / \mathrm{L}$ & - & 13,3 & $<10$ & 25,0 \\
\hline Cálcio $(\mathrm{CaO})$ & $\mathrm{mg} / \mathrm{L}$ & 515,25 & 863,9 & 71 & 2614,7 \\
\hline Chumbo & $\mathrm{mg} / \mathrm{L}$ & - & $<2,50$ & $<2,50$ & $<2,50$ \\
\hline Cloreto & $\mathrm{mg} / \mathrm{L}$ & $1.218,91$ & - & 480 & 2.300 \\
\hline Cobre & $\mathrm{mg} / \mathrm{L}$ & - & 0,50 & $<0,2$ & 3,2 \\
\hline Condutividade & $\mu \mathrm{S} / \mathrm{cm}$ & - & 6.553 & 3.780 & 12.500 \\
\hline DBO5 & $\mathrm{mg} / \mathrm{L}$ & $16.949,76$ & $11.331,1$ & 5.879 & 75.330 \\
\hline DQO & $\mathrm{mg} / \mathrm{L}$ & $28.450,00$ & $31.504,6$ & 9.200 & 97.400 \\
\hline Dureza & $\mathrm{mg} / \mathrm{L}$ & - & $4.505,7$ & 1.080 & 9.200 \\
\hline Etanol-CG & $\% \mathrm{v} / \mathrm{v}$ & 0,09 & - & 0,01 & 1,19 \\
\hline Ferro & $\mathrm{mg} / \mathrm{L}$ & 25,17 & 14,71 & 2 & 200 \\
\hline Fósforo total & $\mathrm{mg} / \mathrm{L}$ & 60,41 & 32,0 & $<10$ & 188 \\
\hline Glicerol & $\% \mathrm{v} / \mathrm{v}$ & 0,59 & $<1,00$ & 0,26 & 2,50 \\
\hline Levedura & $\% \mathrm{v} / \mathrm{v}$ & 1,35 & - & 0,38 & 5,00 \\
\hline Lítio & $\mathrm{mg} / \mathrm{L}$ & - & $<0,50$ & $<0,50$ & $<0,50$ \\
\hline Magnésio $(\mathrm{MgO})$ & $\mathrm{mg} / \mathrm{L}$ & 225,64 & 535,0 & 97 & $1.112,9$ \\
\hline Manganês & $\mathrm{mg} / \mathrm{L}$ & 4,82 & 4,50 & 1 & 12 \\
\hline Nitrogênio total & $\mathrm{mg} / \mathrm{L}$ & 356,63 & 352,5 & 81,2 & $1.214,6$ \\
\hline Nitrogênio amoniacal & $\mathrm{mg} / \mathrm{L}$ & 10,94 & 36,6 & 0,4 & 220,0 \\
\hline Nitrogênio nitrato & $\mathrm{mg} / \mathrm{L}$ & - & $<0,8$ & $<0,1$ & 4,2 \\
\hline Nitrogênio nitrito & $\mathrm{mg} / \mathrm{L}$ & - & $<0,2$ & $<0,1$ & 1,2 \\
\hline $\mathrm{pH}$ & - & 4,15 & 4,8 & 3,50 & 4,90 \\
\hline Potássio total & $\mathrm{mg} / \mathrm{L}$ & $2.034,89$ & $2.666,6$ & 814 & $7.611,5$ \\
\hline Resíduos Sedimentáveis & $\mathrm{mg} / \mathrm{L}$ & 2,29 & 7,0 & 0,1 & 40 \\
\hline Sódio & $\mathrm{mg} / \mathrm{L}$ & 51,55 & 30,6 & 2,7 & 220 \\
\hline Sólidos Dissolvidos Fixos & $\mathrm{mg} / \mathrm{L}$ & $11.872,36$ & $7.517,7$ & 921 & 24.020 \\
\hline Sólidos Dissolvidos Totais & $\mathrm{mg} / \mathrm{L}$ & $18.420,06$ & $24.520,4$ & 1.509 & 45.630 \\
\hline Sólidos Dissolvidos Volát. & $\mathrm{mg} / \mathrm{L}$ & $6.579,58$ & $1.7004,3$ & 588 & 29.325 \\
\hline Sólidos Suspensos Fixos & $\mathrm{mg} / \mathrm{L}$ & 294,38 & $<327,8$ & $<20$ & 2.350 \\
\hline Sólidos Suspensos Totais & $\mathrm{mg} / \mathrm{L}$ & $3.966,84$ & - & 260 & 9.500 \\
\hline Sólidos Suspensos Voláteis & $\mathrm{mg} / \mathrm{L}$ & $3.632,16$ & 4901,1 & 40 & 15.900 \\
\hline Sólidos Totais (ST) & $\mathrm{mg} / \mathrm{L}$ & $25.154,61$ & $29.596,3$ & 10.780 & 56.780 \\
\hline Sulfato & $\mathrm{mg} / \mathrm{L}$ & $1.537,66$ & 861,2 & 92,3 & $3.363,5$ \\
\hline Sulfito & $\mathrm{mg} / \mathrm{L}$ & 35,90 & - & 5 & 153 \\
\hline Temperatura & ${ }^{\circ} \mathrm{C}$ & 89,16 & - & 65 & 110,5 \\
\hline Zinco & $\mathrm{mg} / \mathrm{L}$ & - & $<1,0$ & $<0,5$ & 4,6 \\
\hline
\end{tabular}

Fontes: *1. ELIA NETO \& NAKAHODO (1995); *2. ELIA NETO \& ZOTELLI, (2008). 
Uma característica que não aparece nestas referências é a eventual presença de antibióticos procedentes das dornas de fermentação que, por serem termoestáveis permanecem ativos depois da destilação (BRASMETANO, 2011; OMNIS BIOTECHNOLOGY, 2013후 ; USINA SÃO MARTINHO, 2013 ${ }^{6}$ ). Segundo Pires (informação

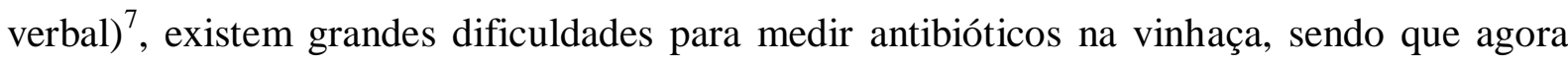
estão sendo desenvolvidos protocolos para identificar e quantificar a presença destes compostos.

Estas características fazem deste resíduo um potencial poluidor de solos, águas superficiais e subterrâneas, além de ser uma fonte potencial de emissão de metano, se não for adequadamente tratado. A vinhaça é classificada como resíduo líquido Classe II A - Não Inerte, por conter substâncias solubilizadas a concentrações superiores aos padrões de potabilidade da água, conforme o anexo G da norma ABNT NBR 10.004 (ABNT, 2004).

\subsection{Fertirrigação com vinhaça}

Entende-se como fertirrigação o processo conjunto de irrigação e adubação, utilizando a própria água para distribuir o fertilizante na lavoura. No caso da fertirrigação com vinhaça, este resíduo é utilizado como fertilizante podendo assim substituir parte da adubação mineral. Existe variação entre as usinas sobre o método utilizado para realizar a fertirrigação, pelas particularidades relacionadas à orografia, espaçamento e localização dos talhões, etc., provocando uma infinidade de possibilidades, combinações e configurações para o transporte e a distribuição da vinhaça. Uma situação comumente encontrada é o recalque da vinhaça para cotas elevadas onde é armazenada em lagoas a céu aberto, a partir das quais é transportada ao canavial mediante canais, dutos (LORENCINI, 2009), caminhões-tanque e rodotrem.

As lagoas de armazenamento são um reservatório de segurança que permitem amortecer as diferenças entre o ritmo de produção e o de distribuição, evitando a aplicação em excesso da vinhaça ou o descarte em áreas impróprias. Ainda, as lagoas são pontos de abastecimento de caminhões-tanque que junto com a aspersão representam os principais sistemas de distribuição e aplicação da vinhaça (PAREDES, 2011). Segundo a Norma CETESB P4.231 Dez/2006, na construção dos reservatórios e dos canais de distribuição, devem ser utilizadas geomembranas sintéticas de impermeabilização (PEAD, Asfáltica, PVC e geotêxtil).

\footnotetext{
${ }^{5}$ Visita ao biodigestor instalado pela OMNIS BIOTECHNOLOGY na Usina Ester, Cosmópolis/SP, abril de 2013.

${ }^{6}$ Visita ao biodigestor da usina São Martinho, Pradópolis/SP, novembro de 2013.

${ }^{7}$ Informação dada pelo Prof. Dr. Eduardo Cleto Pires, durante o exame de qualificação da presente dissertação, São Paulo, agosto de 2014.
} 
Entretanto, estas membranas não suportam a alta temperatura da vinhaça que sai da destilaria, sendo necessário, as vezes, sistemas de esfriamento. Além disso, tanto a instalação de bombas e tubulações, como a disponibilidade da frota de caminhões e sistema de aspersão, exigem elevados investimentos e custos de manutenção, proporcionais ao volume de vinhaça e à superfície a ser fertirrigada.

Existem vários sistemas de fertirrigação, sendo os mais importantes caracterizados a seguir. No passado, era comum a aplicação por inundação, onde a vinhaça diluída tinha entrada pela parte mais elevada do talhão, produzindo uma inundação bastante heterogênea, principalmente em solos arenosos. No início da distribuição podiam ocorrer danos à planta devido à elevada quantidade aplicada, com consequentes problemas de salinização do solo. Outro sistema ultrapassado é a aplicação por infiltração, técnica que exige uma preparação prévia do terreno com canais e sulcos com uma rigorosa sistematização, de acordo com a topografia e o tipo de solo. Matioli e Menezes (1984) afirmaram que este sistema, pode demandar muita mão de obra, além da aplicação de dosagens excessivas e heterogênea, que podem implicar em graves prejuízos para a cultura e o solo. Diante destas dificuldades, seu emprego a passou a ser bastante restrito (LORENCINI, 2009).

Em um passado recente, o uso de caminhões-tanque era o sistema de fertirrigação mais difundido, como mostra o estudo realizado por Matioli e Menezes (1984), o qual indicava a predominância do uso destes equipamentos nos canaviais paulistas, atingindo $80 \%$ da área total irrigada com vinhaça pura. Este sistema tem baixo custo de implantação e vantagens na mobilidade, mas precisa de estradas em bom estado, frota de veículos, sistematização dos talhões e um planejamento de corte de cana de modo a permitir a aplicação 24 horas por dia. Como desvantagens desse sistema se encontram a compactação do solo pelos veículos, a impossibilidade de aplicação na cana-planta, a inviabilidade da diluição da vinhaça e as dificuldades de aplicação em dias de chuva (ORLANDO FILHO et al.1983). O caminhãotanque transporta e distribui a vinhaça no campo, despejando-a pela traseira por gravidade ou bombeamento. A distribuição por gravidade é feita normalmente por chuveiros que podem atingir de 3 a 5 linhas de cana ou descarga rápida defletida em pratos formando um leque de distribuição (Figura 4). A distribuição por bombeamento é realizada com bombas acionada pela tomada de força do caminhão (ANA, 2009), o que proporciona uma vazão constante. 


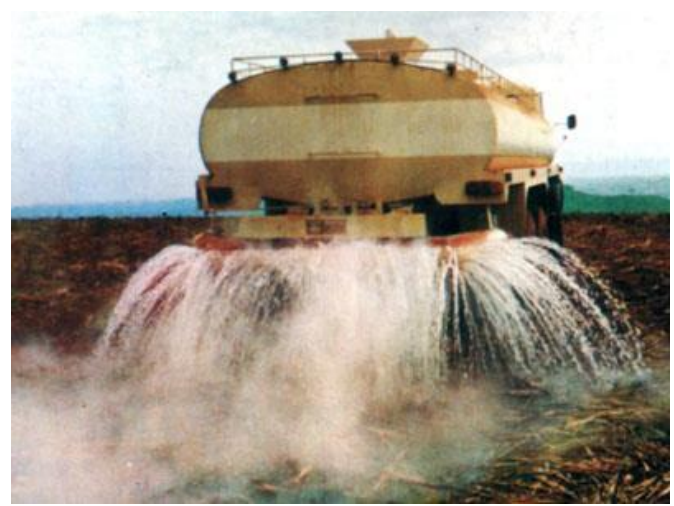

Figura 4. Descarga rápida defletida em pratos de um caminhão-tanque sobre a lavoura. Fonte: Elia Neto (2014).

A capacidade do tanque varia entre 7 e $18 \mathrm{~m}^{3}$, sendo que os veículos de maior capacidade transportam e aplicam o resíduo mais economicamente, porém os de menor capacidade apresentam maior versatilidade. Este sistema está limitado pela distancia econômica do ponto de carregamento até as áreas de aplicação, devido principalmente ao consumo de combustível.

Posteriormente, passou a ser muito difundida a fertirrigação por aspersão onde, em primeiro lugar, são precisos canais, dutos ou o uso de rodotrem para o transporte da vinhaça até os talhões. Posteriormente, são aplicadas duas alternativas:

a) sistema de montagem direta;

b) carretel enrolador ou hydroroll.

A aspersão com montagem direta consiste em um conjunto motobomba com um aspersor tipo canhão-hidráulico, montado em chassi com rodas, aspergindo vinhaça sugada diretamente de um canal (Figura 5). O canhão pode ser equipado com extensões para aumentar o espaçamento entre canais e diminuir a necessidade destes nos canaviais, implicando em menores custos de implantação.

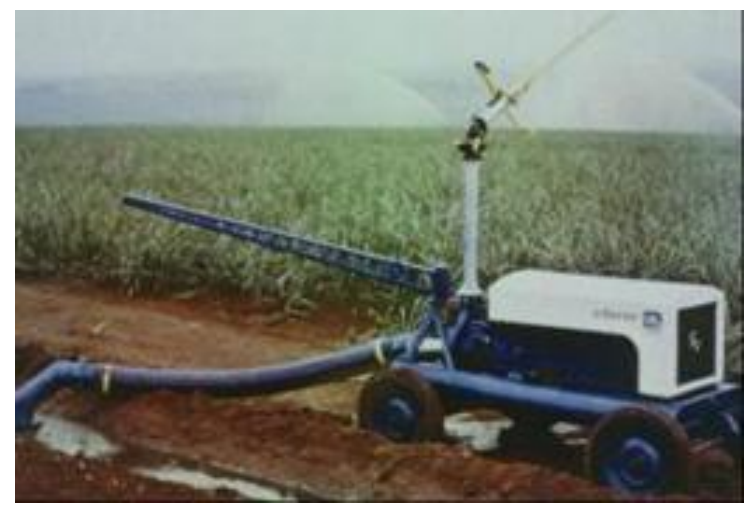

Figura 5. Aspersor tipo montagem direta sugada de canal.

Fonte: ANA (2009). 
Igualmente, o carretel enrolador precisa de uma motobomba que alimente as tubulações donde são acoplados estes equipamentos. Este é um sistema que possui um aspersor tipo canhão, montado em um pequeno chassi com rodas que se desloca continuamente puxado pela própria mangueira ao ser enrolada no carretel (Figura 6). O carretel gira acionado por uma turbina hidráulica com um redutor de velocidade.
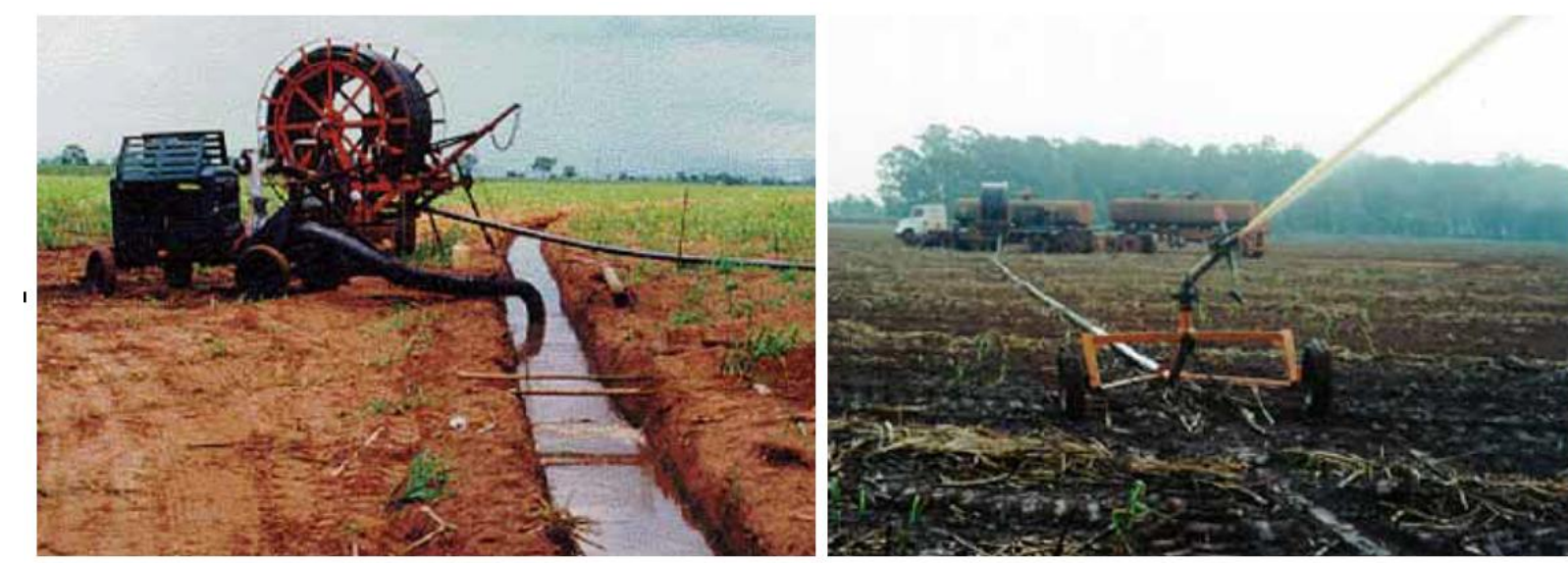

Figura 6. Carretel enrolador com captação no canal e acoplado diretamente no caminhão. Fonte: ANA (2009).

Segundo Leme et al (1979), o método de aplicação de vinhaça por aspersão com canhão hidráulico, apresenta como vantagem poder ser usado em áreas com declive acentuado e operado em qualquer tipo de solo, assim como em todos os ciclos e fases da cultura. Este sistema permite um perfeito controle da quantidade de vinhaça aplicada, irrigando extensas áreas por unidade de tempo, o que implica em baixo custo operacional e em economia de mão-de-obra. Como inconveniente este sistema apresenta a curta vida útil dos aspersores e das tubulações de aço zincado ou alumínio, devido ao elevado poder corrosivo da vinhaça.

A distância econômica de aplicação de vinhaça é definida a partir do ponto em que os custos de transporte seriam maiores aos da adubação mineral. Esta distância é função da topografia local e da concentração de potássio da vinhaça, pois estas variáveis afetam o transporte e a aplicação, que são comparados com os custos de adubação mineral. Segundo o manual da ANA (2009) em um passado recente, o sistema de "rodotrem e aspersão" apresentava a distância econômica de $12 \mathrm{~km}$, mas com o incremento dos preços do adubo mineral, Elia Neto et al. (2008) estimou que a distância econômica é de aproximadamente 38 km (Figura 7). 


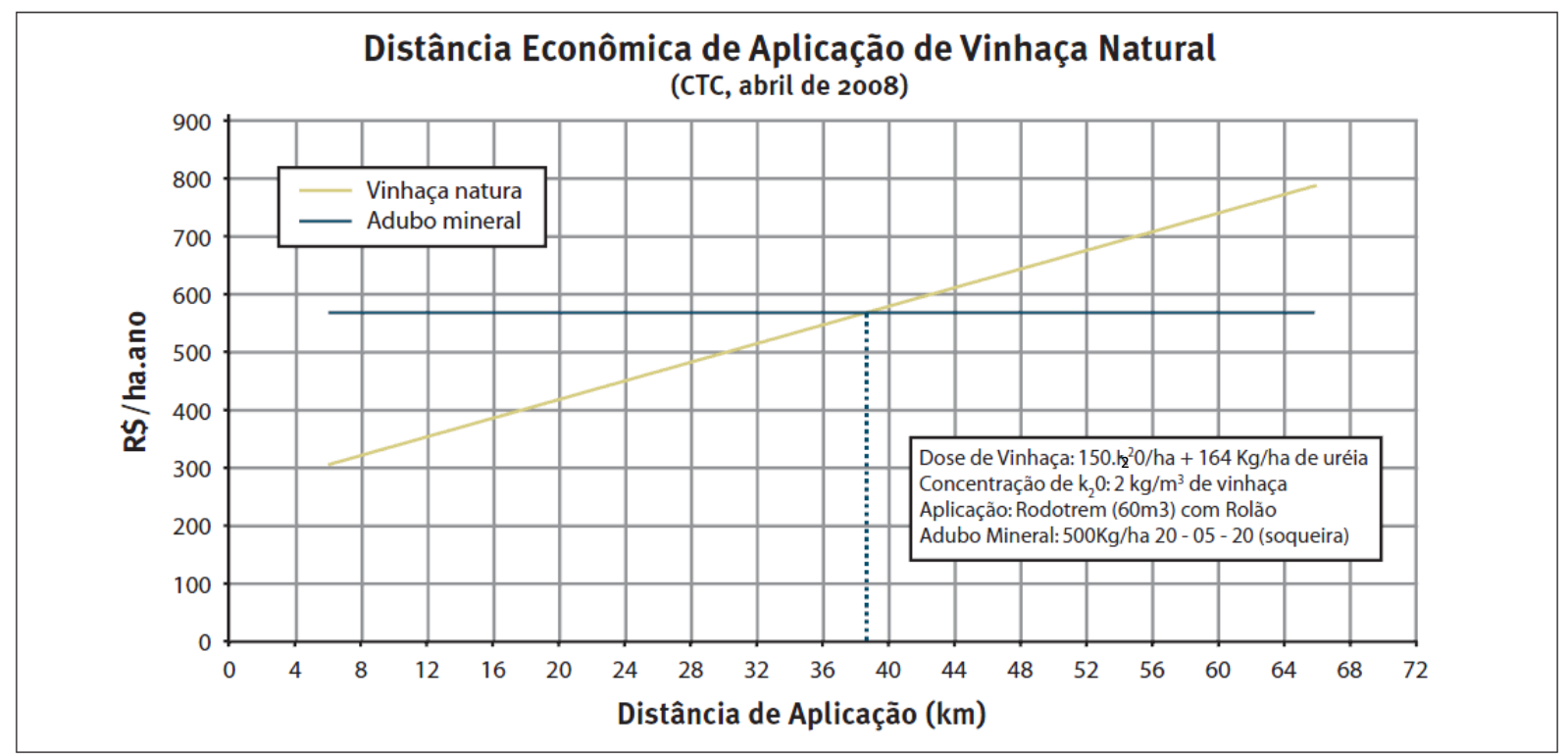

Figura 7. Distância econômica de fertirrigação.

Fonte: ELIA NETO et al. (2008).

Existem poucos estudos publicados sobre a porcentagem da área de cultivo classificada por sistema de fertirrigação. As referências mais recentes são Macedo (2004) e Souza (2005) utilizando dados do ano de 2002, para as usinas associadas à Copersucar $^{8}$, mostrados na Tabela 5.

Tabela 5. Sistemas de aplicação de vinhaça nas lavouras de cana-de-açúcar do Estado de São Paulo.

\begin{tabular}{|c|c|c|c|}
\hline Sistema de transporte e aplicação & Maquinaria & $\begin{array}{c}\text { \% da área } \\
\text { fertirrigada }\end{array}$ & $\begin{array}{c}\text { Dosagem } \\
\mathbf{m}^{3} / \mathbf{h a}\end{array}$ \\
\hline $\begin{array}{l}\text { Caminhão-tanque aplicando } \\
\text { diretamente }\end{array}$ & MB2318 com tanque de $15 \mathrm{~m}^{3}$ & 6 & 100 \\
\hline \multirow{3}{*}{ Aspersão } & Montagem direta & 10 & \multirow{3}{*}{150} \\
\hline & Canal com rolão & 53 & \\
\hline & Rodotrem com dois tanques de $30 \mathrm{~m}^{3} / \mathrm{cada}$ e rolão & 31 & \\
\hline TOTAL & & 100 & 131,5 \\
\hline
\end{tabular}

Fonte: Macedo et al (2004) e Souza (2005).

Conforme se verifica na Tabela 5, as diferentes formas de aspersão são utilizadas em 94\% da superfície fertirrigada. Por outro lado, a superfície que precisa de vinhaça transportada em caminhão é de $37 \%$, sendo o restante transportado em canais.

\footnotetext{
${ }^{8} \mathrm{http}: / /$ www.copersucar.com.br/
} 


\subsection{Concentração da vinhaça}

\subsubsection{Processo da concentração}

Concentrar a vinhaça, através do processo físico da evaporação, é uma das alternativas para economizar no seu transporte. A evaporação permite concentrar os sólidos presentes na vinhaça em uma parte do líquido e o vapor resultante pode ser condensado para fornecer água de reúso ao processo da usina.

A evaporação é uma importante operação unitária ${ }^{9}$ dos processos na indústria química, abrangendo: alimentos, polpas e papel, sucroalcooleira, farmacêuticas, fertilizantes, etc. É utilizada basicamente para concentrar uma solução, que consista de um soluto não volátil e um solvente volátil. O princípio de funcionamento dos evaporadores é uma superfície de transferência de calor do fluido de aquecimento com a dissolução que se quer concentrar, não havendo contato entre eles e existindo só uma troca térmica. O fluido a concentrar deve circular por um meio que permita a separação do vapor e do líquido concentrado.

$\mathrm{O}$ tipo de equipamento utilizado depende das características do soluto e do solvente. O soluto pode ser termo-sensível, tender a polimerizar, aglomerar ou incrustar sobre a área de troca térmica. Por outro lado, o solvente pode ter alta viscosidade dificultando o fluxo e a troca térmica (ETAL, 2011) ${ }^{10}$, sendo que a viscosidade do concentrado é normalmente o que determina o limite superior de concentração (GEA, 2007). A seleção do evaporador também depende da concentração e da taxa de evaporação que precisa ser obtida, do tipo de sistema de aquecimento ou recuperação de calor, e em particular da viscosidade do fluido. A Tabela 6 resume as propriedades físicas da vinhaça procedente da destilação da cana-de-açúcar que determinam o tipo de equipamento a escolher.

Tabela 6. Propriedades físicas da vinhaça in natura e concentrada.

\begin{tabular}{lcc}
\hline & Vinhaça in natura & Vinhaça concentrada \\
\hline Teor de sólidos & $23-81 \mathrm{~g} / \mathrm{l}(\mathrm{CETESP}, 1982)$ & $500-650 \mathrm{~g} / \mathrm{l}\left(50 \text { a } 65^{\circ} \mathrm{Brix}\right)^{11}$ \\
Viscosidade & $1 \mathrm{cP}$ & 20 a $150 \mathrm{cP}$ \\
\hline
\end{tabular}

\footnotetext{
${ }^{9} \mathrm{Na}$ engenharia química e em seus campos relacionados, uma operação unitária é uma etapa básica de um processo. Um processo tem várias operações unitárias presentes para que possa se obter o produto desejado. Uma operação unitária sempre tem o mesmo objetivo, independente da natureza química dos componentes envolvidos (ISENMANN, 2013).

${ }^{10}$ ETAL. Sistemas evaporativos para indústria de alimentos, http://www.etaltecnologia.com.br/, 2011.

${ }^{11} \mathrm{O}$ grau Brix $\left({ }^{\circ} \mathrm{Bx}\right)$ indica a quantidade total de sacarose dissolvida em um líquido. Uma solução de $25^{\circ} \mathrm{Bx}$ contem $25 \mathrm{~g}$ de açúcar (sacarose) por $100 \mathrm{~g}$ de dissolução. No caso da vinhaça, os sólidos presentes não são somente sacarose. Por este motivo, para medir a concentração da vinhaça, convencionalmente se utiliza a seguinte definição de grau Brix: gramas de sólidos totais dissolvidos por cada 100 gramas de efluente.
} 


\begin{tabular}{lcc}
\hline & Vinhaça in natura & Vinhaça concentrada \\
\hline Densidade & $1.030 \mathrm{~kg} / \mathrm{m}^{3}$ & $1.300-1.400 \mathrm{~kg} / \mathrm{m}^{3}$ \\
Temperatura & $60-100^{\circ} \mathrm{C}$ & $50-60{ }^{\circ} \mathrm{C}$ \\
\hline
\end{tabular}

Fonte: Adaptado de GEA, 2007.

Tradicionalmente, os evaporadores de película descendente (falling film) são usados para baixas viscosidades (de até $100 \mathrm{cP}^{12}$ ) e elevadas taxas de evaporação para instalações de grande porte com capacidade para concentrar ate $150 \mathrm{~m}^{3}$ de vinhaça in natura por hora (GEA, 2007). Neste tipo de evaporador, uma película de fluido a ser concentrado desce por gravidade mantendo o contato com a superfície de troca térmica. Durante este contato o fluido se aquece até a volatilização do solvente em forma de vapor. A Figura 8 ilustra como são os

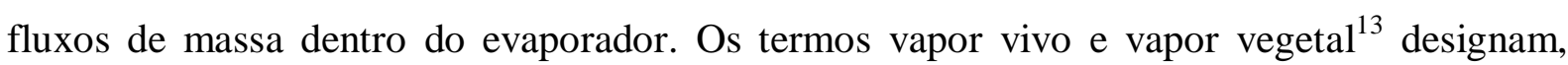
respectivamente, ao vapor de aquecimento e ao proveniente da evaporação.

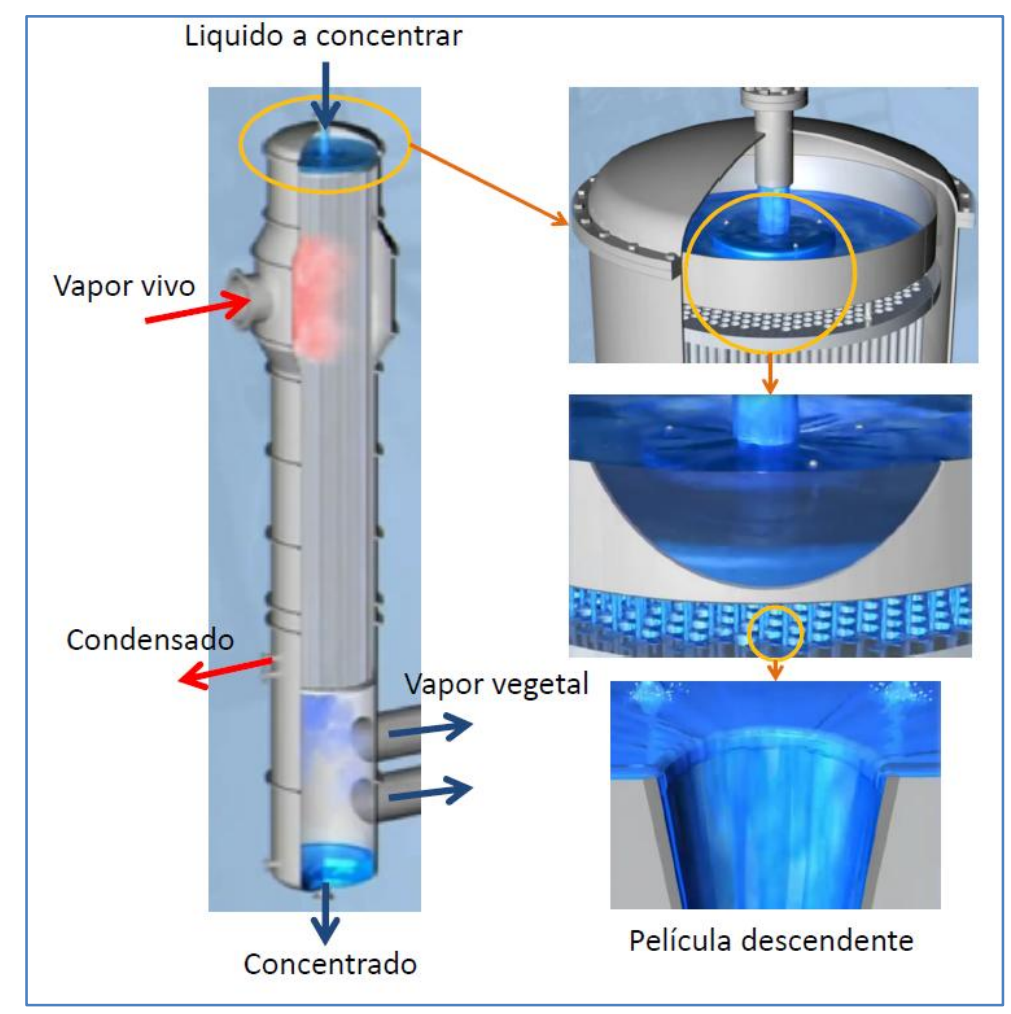

Figura 8. Evaporador de película descendente. Fonte: Adaptação de animação da GEA (2014).

Segundo Rodrigues (2008), esta é a tecnologia para concentração oferecida por Vogelbusch, GEA e Alfa Laval, entre outros fabricantes, mas este tipo de evaporador sofre os

\footnotetext{
${ }^{12}$ A unidade no Sistema Cegesimal de unidades para a viscosidade dinâmica é o poise (P). O centipoise (cP) é seu submúltiplo mais usado.

${ }^{13}$ Nas usinas de álcool é denominado como "vapor vivo" o vapor de processo, e como "vapor vegetal" aquele vapor resultante da evaporação da água em uma operação de concentração.
} 
problemas relacionados à rápida incrustação e cristalização espontânea à medida que o teor de sólidos aumenta. As incrustações diminuem a troca térmica e a eficiência do evaporador, aumentando consequentemente as paradas, insumos para limpeza e custos para manutenção. Para evitar este problema foi desenvolvida a tecnologia de névoa turbulenta descendente também conhecida por Thermally Accelerated Short Time Evaporator (TASTE), onde o líquido a concentrar é transformado em névoa na entrada do evaporador por meio de um difusor.

O processo de evaporação precisa de muita energia, consequentemente a viabilidade de seu emprego depende determinantemente de diminuir o consumo de combustíveis, pois normalmente o vapor saturado procedente de caldeiras é utilizado como fonte de calor. Para reduzir o consumo utilizam-se basicamente duas estratégias: o sistema de evaporação em múltiplos efeitos e o uso de fontes residuais de calor.

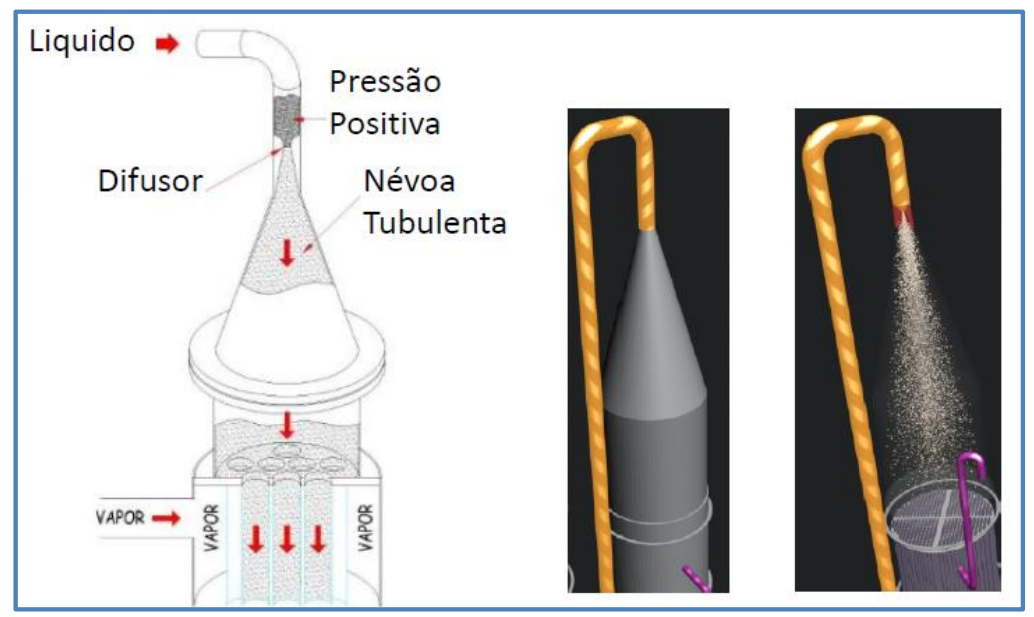

Figura 9. Tecnologia Thermally Accelerated Short Time Evaporator (TASTE). Fonte: Adaptado de LME (2014) ${ }^{14}$, e Dedini (2010) ${ }^{15}$.

No sistema de evaporação em múltiplos efeitos (Figura 10), um evaporador é montado em continuação ao outro, de modo que o vapor vegetal de um evaporador é utilizado como fonte de calor para o seguinte e assim sucessivamente. Cada evaporador individual é chamado de "efeito". O vapor vegetal produzido no último efeito passa por um condensador, encerrando o processo.

Quanto maior o número de efeitos, maior será a redução do consumo de energia. Além da economia de vapor, também se obtém uma economia de água de resfriamento no condensador, já que este último condensa somente o vapor vegetal gerado no último efeito.

\footnotetext{
${ }^{14}$ www.lme.com.br.

${ }^{15}$ DEDINI. Concentração de Vinhaça. Tecnologia T.A.S.T.E “Thermally Accelerated Short Time Evaporator", 2010.
} 
Por outro lado, o aumento de número de efeitos aumenta os custos de investimento e de manutenção (CARVALHO; SILVA, 2008)

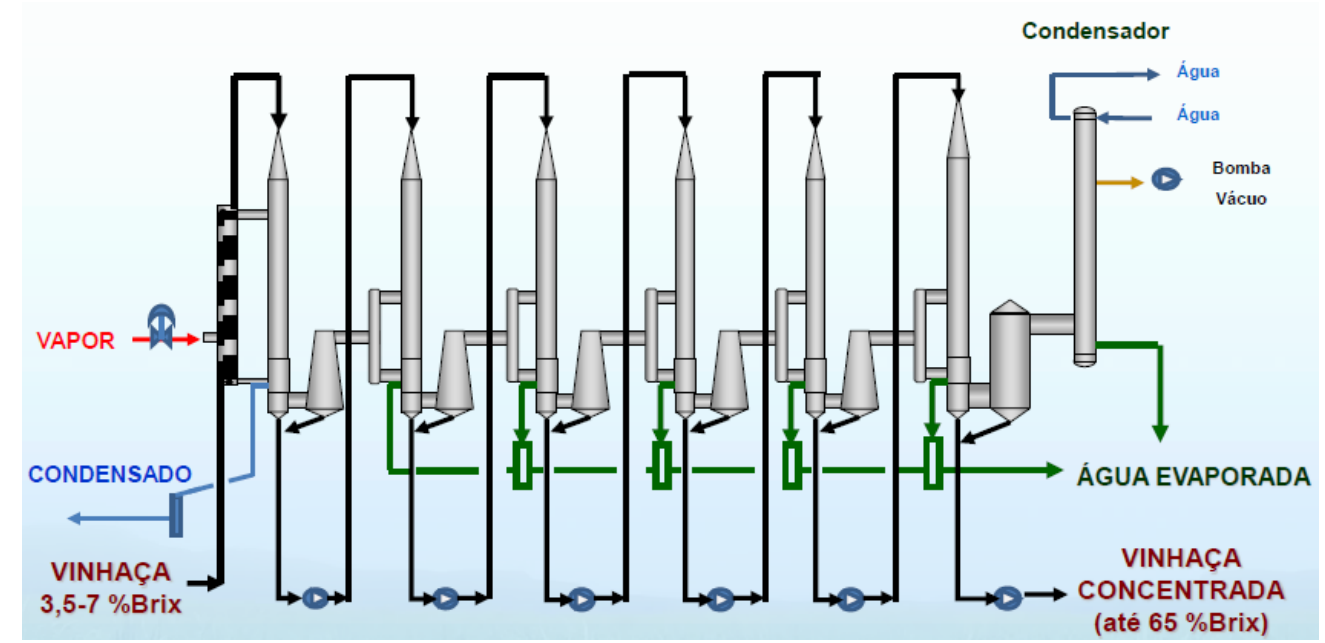

Figura 10. Evaporador de seis efeitos.

Fonte: Dedini, 2010

Com relação ao uso de fontes residuais de calor, existem duas possibilidades:

a) acoplar o evaporador à coluna de destilação de tal forma que os vapores provenientes dela sirvam como fonte de calor para o seguinte efeito. Isto é, a coluna de destilação funcionaria como se fosse o primeiro efeito do evaporador.

b) utilizar o os gases da caldeira produzidos na combustão do bagaço como fonte de aquecimento, mas isto exige de mais potência de exaustão para coseguir evacuar os gases pela chaminé. Esta tecnologia encontra-se em desenvolvimento.

Segundo o fabricante Citrotec SL (2013) ${ }^{16}$, que fornece três modelos de evaporadores de múltiplo efeito baseados no principio de névoa turbulenta, os consumos de vapor dos equipamentos são os mostrados na Tabela 7. Este fabricante indica que, para seus modelos com aproveitamento de calor residual, não é necessário consumo de vapor adicional.

Tabela 7. Consumo de vapor por diferentes modelos de evaporadores.

\begin{tabular}{cccc}
\hline \multirow{2}{*}{ Tecnologia: } & Fonte de calor & Número de efeitos & $\begin{array}{c}\text { Consumo de kg vapor } \\
\text { por kg de evaporação }\end{array}$ \\
\hline \multirow{2}{*}{ Ecovin ${ }^{*}$} & & 5 & $1: 4,3$ \\
& Vapor de processo de 1,5 bar & 6 & $1: 5,3$ \\
\cline { 3 - 4 } & & 7 & $1: 6,2$ \\
\hline EcovinJL ${ }^{\circledR}$ & Vapor de colunas de destilação & $5-7$ & 0 \\
\hline Ecowaste ${ }^{*}$ & Gases de exaustão das caldeiras & $5-7$ & 0 \\
\hline
\end{tabular}

Fonte: Citrotec $®, 2013$

${ }^{16} \mathrm{http}: / / \mathrm{www} \cdot$ citrotec.com.br/ 


\subsubsection{Implantação da tecnologia e estudos de caso}

A partir do ano 2009, a utilização de concentradores de vinhaça se encontra em expansão. As normas que restringem a dosagem de vinhaça, assim como a disponibilidade de equipamentos que aproveitam calor residual de outros processos, têm impulsionado este aumento na implantação. Os primeiros evaporadores de vinhaça datam de 1954, instalados pela companhia austríaca Vogelbusch. Esta empresa desenvolveu o evaporador falling film, mostrado na Figura 8, também chamado de película fina, que utiliza o princípio de evaporação de filme descendente (BIASE, 2007). As primeiras experiências no Brasil datam de 1978, sendo que um caso foi o da Usina Tiúma/PE, com um evaporador integrado na destilaria, e outro caso foi o da Usina Santa Elisa/SP, mas estas unidades apresentavam problemas com incrustações e elevado consumo energético respectivamente (CARVALHO; SILVA, 2008). O uso de sistemas Clean-in-Place (CIP $)^{17}$ e TASTE reduziram as incrustações. O consumo energético foi diminuído com sistemas de cogeração e com aproveitamento de calor residual utilizando concentradores acoplados à destilaria. No ano 2014, os principais fornecedores de equipamentos no Brasil são a empresa Citrotec ${ }^{18}$ e a Dedini ${ }^{19}{ }^{19}$.

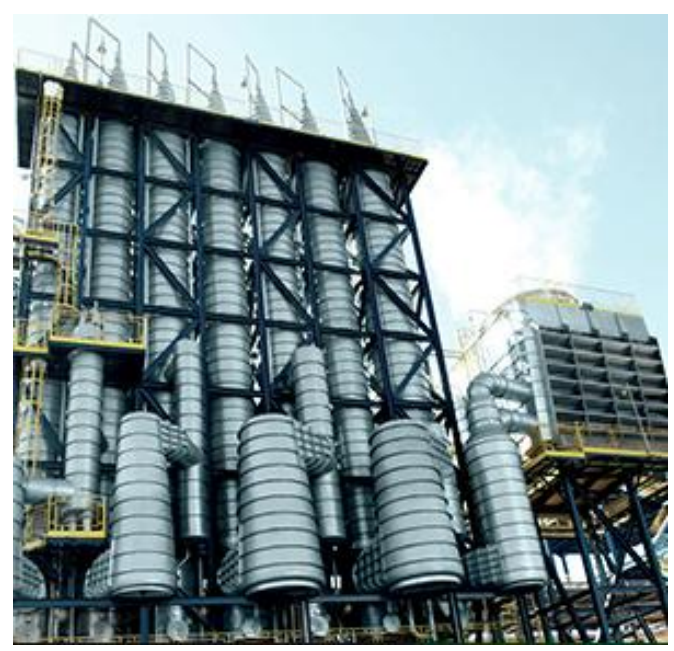

Figura 11. Concentrador de vinhaça Ecovin.

Fonte: Citrotec $®$ (2014).

A unidade do Grupo Cerradinho (atual NG Bioenergia), em Potirendaba/SP, instalou em 2008 um concentrador de vinhaça com capacidade para passar $100 \mathrm{~m}^{3} / \mathrm{h}$ de $4,5^{\circ}$ Brix até $22^{\circ}$ Brix (JORNALCANA, 2009). A partir desse momento várias destilarias tem adquirido

\footnotetext{
${ }^{17}$ Clean-in-place (CIP) é um método que utiliza químicos para a limpeza sem desmontagem, sendo empregado para superfícies internas dos tubos, vasos, equipamentos de processo, filtros e acessórios associados.

${ }^{18}$ www.citrotec.com.br

${ }^{19}$ www.codistil.com.br/
} 
este equipamento, como indica Santa Cruz (2011). Na Tabela 8 se enumeram exemplos de usinas que tem instalado concentradores de vinhaça.

Tabela 8. Concentradores de vinhaça instalados.

\begin{tabular}{lcc}
\hline Usina & Localização & $\begin{array}{c}\text { Capacidade do } \\
\text { concentrador }\end{array}$ \\
\hline Usina Boa Vista (Grupo São Martinho) & Quirinópolis/GO & $200 \mathrm{~m}^{3} / \mathrm{h}$ \\
Usina Rio Pardo & Cerqueira & $110 \mathrm{~m}^{3 / h}$ \\
Usina Angélica & César/SP & $200 \mathrm{~m}^{3 / h}$ \\
Usina Guarani (Unidade Cruz Alta) & Angélica/MS & $220 \mathrm{~m}^{3 / h}$ \\
Usina Santa Rosa & Olímpia/SP & $?$ \\
Usina Zanin & Boituva/SP & $?$ \\
Usina da Pedra & Araraquara/SP & $?$ \\
\hline
\end{tabular}

Fonte: Citrotec ${ }^{\circledR}$ (2014) e Santa Cruz (2011).

Estas usinas contam geralmente com caminhões de 12 a $15 \mathrm{~m}^{3}$ de capacidade adaptados para aplicação da vinhaça concentrada como biofertilizante. Os caminhões são preparados para fertilizar várias ruas ao mesmo tempo, aplicando o concentrado sobre as linhas de cana. Este tipo de aplicação é muito mais eficiente ao uso da vinhaça que os sistemas de aspersão, pois não existem perdas nos dutos nem na entrelinha (Figura 12).

Figura 12. Caminhão aplicando vinhaça concentrada.

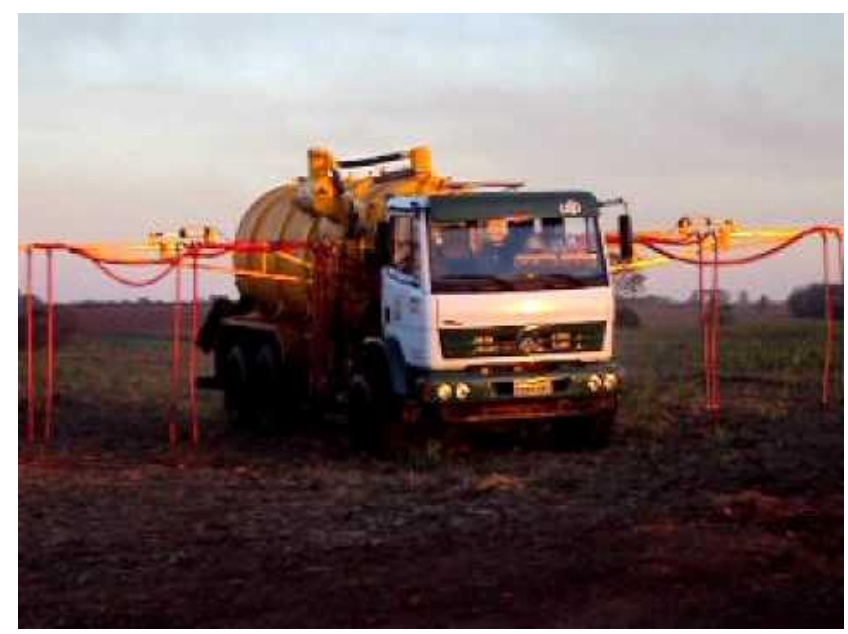

Fonte: Barganha $(2010)^{20}$.

\footnotetext{
${ }^{20}$ https://www.youtube.com/watch?v=eDG-O6_z_Pw
} 


\subsection{Biodigestão anaeróbia da vinhaça}

\subsubsection{Processo da biodigestão}

A digestão anaeróbia é realizada por diversos grupos de microrganismos que convertem a matéria orgânica complexa em biogás, amônia, água e novas células bacterianas (SALOMON, 2007). Este é um processo complexo que envolve muitas espécies de bactérias e sucessivas etapas intermediárias. As principais reações bioquímicas que ocorrem no processo estão representadas na Figura 13 e descritas a seguir (LETTINGA \& RINZEMA, 1985):

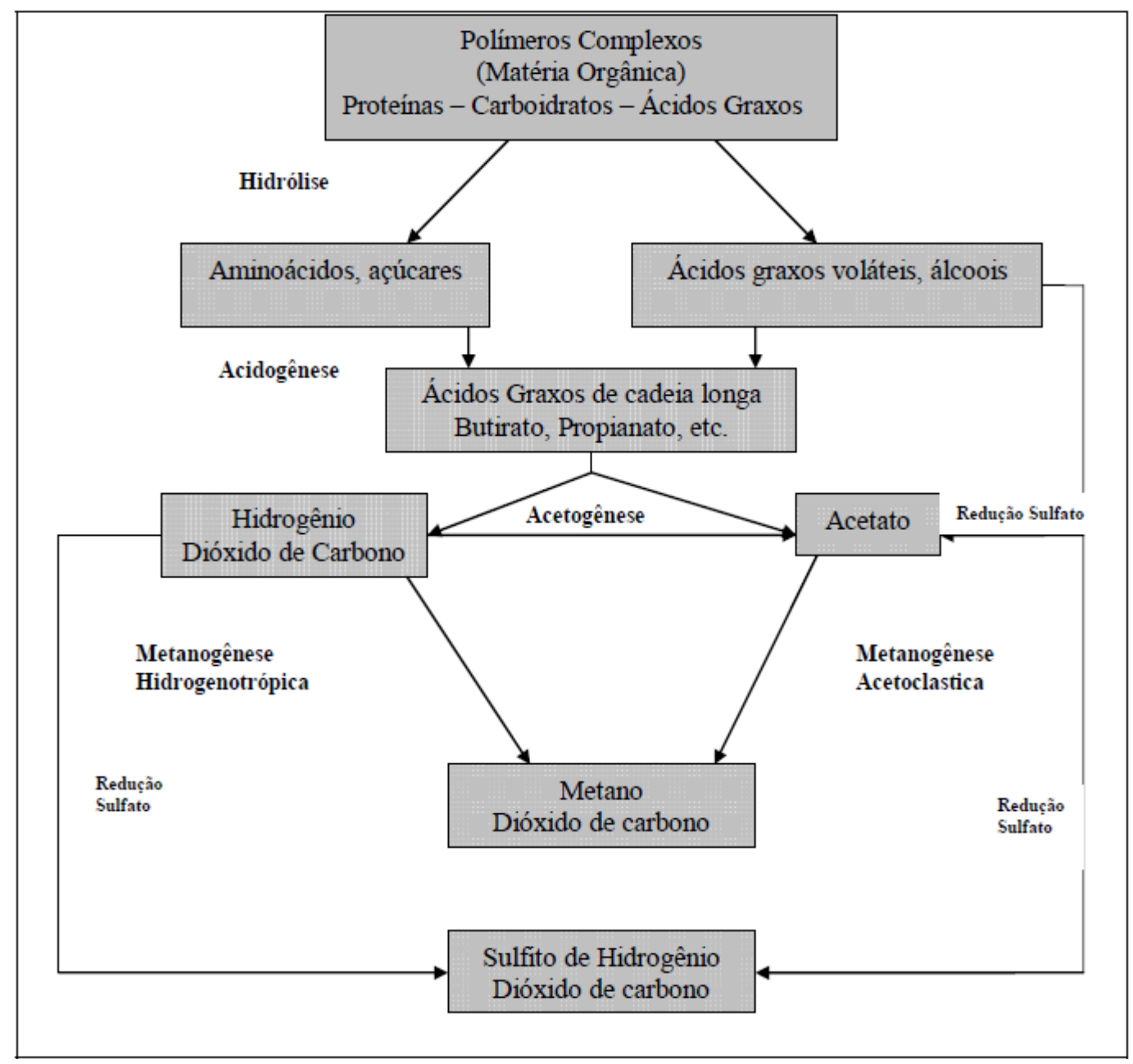

Figura 13. Processo de biodigestão anaeróbia.

Fonte: Salomon (2007), adaptado de Lettinga e Rinzema (1985).

$\left.1^{\circ}\right)$ Hidrólise: A hidrólise da matéria orgânica presente gera compostos mais simples, que podem ser assimilados pelos microrganismos.

$\mathbf{2}^{\mathbf{0}}$ ) Acidogênese: Esta etapa acontece quando a matéria orgânica dissolvida é biodegradada até ácidos graxos voláteis, hidrogênio, dióxido de carbono e alcoóis por uma população heterogênea de bactérias. 
$3^{\text {o }}$ Acetogênese: Nesta etapa os produtos formados anteriormente são oxidados para acetato, hidrogênio e gás carbônico. De todos os produtos produzidos por estes microrganismos, somente o acetato e o hidrogênio podem ser assimilados pelas arqueas metanogênicas.

$\left.4^{\mathbf{0}}\right)$ Metanogênese: $O$ processo de degradação é finalizado nesta etapa, que consiste na transformação dos produtos formados anteriormente em metano e dióxido de carbono pelos microrganismos do grupo de arqueas hidrogenotróficas.

\subsubsection{Biodigestores para vinhaça}

Existem numerosos tipos de biodigestores disponíveis no mercado, podendo funcionar em bateladas ou em fluxo contínuo. Na indústria do etanol seriam mais adequados os reatores de fluxo contínuo, dada a grande produção de vinhaça. Segundo estudos realizados por Souza et al. (1992) os reatores tipo Upflow anaerobic sludge blanket (UASB) se mostrariam adequados para tratamento da vinhaça. O reator UASB consiste em um tanque onde o efluente a tratar, no caso, vinhaça in natura, é injetado na parte inferior, atravessando de forma ascendente uma manta de lodo formada por grânulos de micro-organismos. Na sua parte superior há um separador trifásico, onde é retido o lodo no reator, captado o biogás e retirado o efluente tratado (Figura 14). O problema deste tipo de reator é que quando submetido a alto carregamento orgânico, a turbulência na zona de decantação pode se tornar muito grande devido às elevadas taxas de produção de biogás, resultando no arraste para fora do reator do lodo ativado.

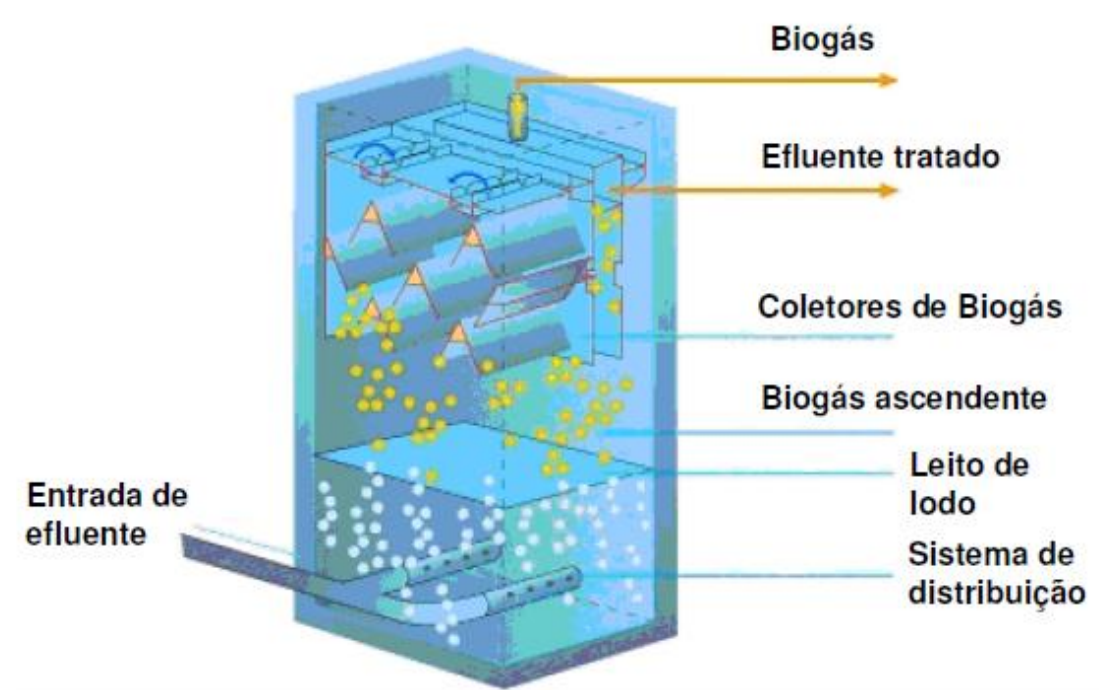

Figura 14. UASB. Reator anaeróbio de fluxo ascendente. Fonte: PAQUES (2014) ${ }^{21}$.

\footnotetext{
${ }^{21} \mathrm{http}: / /$ br.paques.nl/
} 
Para evitar esta perda de lodo foi desenvolvido o Internal Circulation Reactor (IC), que consiste basicamente na instalação de dois reatores UASB sobrepostos, onde o reator inferior recebe um alto carregamento orgânico deixando o superior com pouca carga (estágio de polimento). Sua principal vantagem é a separação do biogás em dois estágios, pois o gás coletado no primeiro estágio proporciona o arraste de efluente e lodo para o topo do reator. Aqui o lodo é separado e internamente recirculado à parte inferior do reator. Este tipo de reator é muito empregado no tratamento dos efluentes das cervejarias.

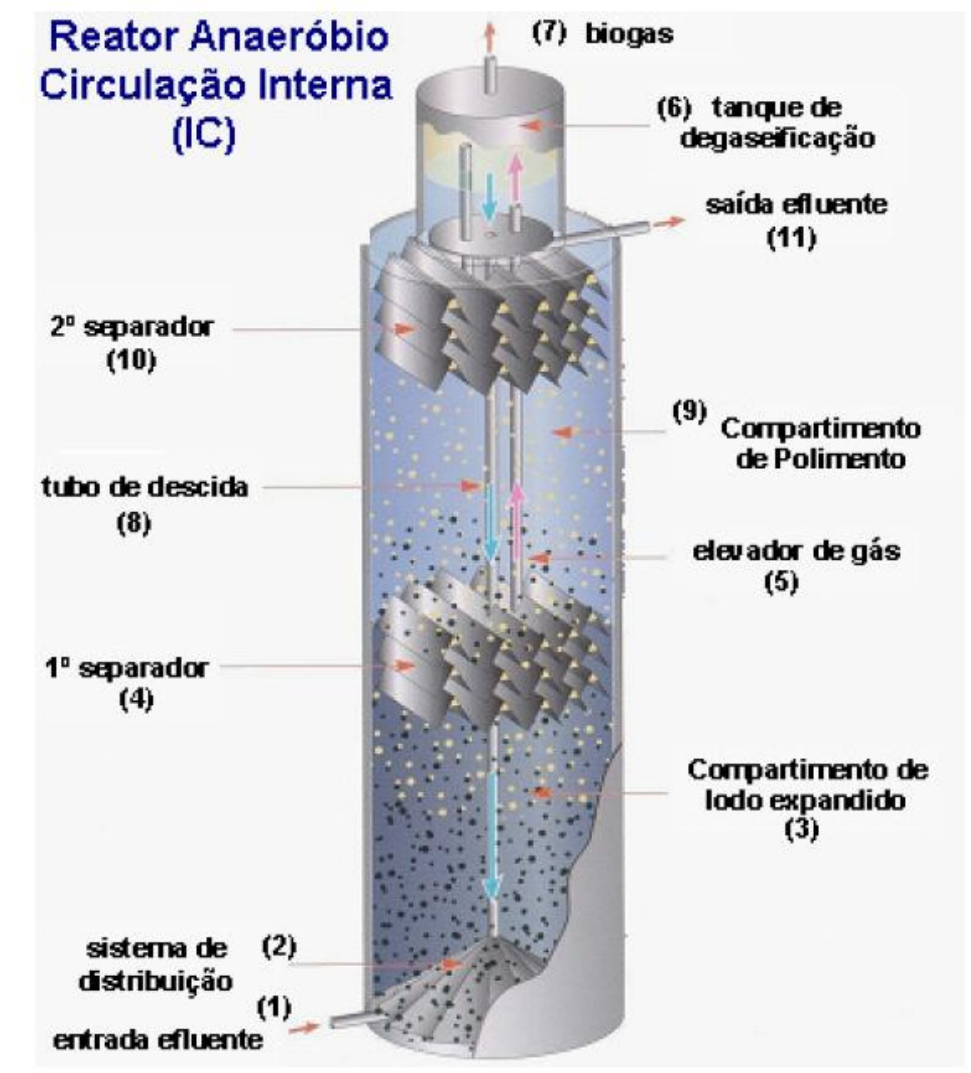

Figura 15. Reator anaeróbio de Circulação Interna (IC).

Fonte: PAQUES (2014).

Por último, também existe a possibilidade de tratamento do efluente em lagoas anaeróbias. Estas lagoas ocupam grandes áreas, com uma profundidade de 4 a 6 m, sendo revestidas com geomembrana e cobertas para a coleta do biogás. São reatores que exigem elevados volumes, pois a taxa de aplicação varia de 2 a $3 \mathrm{~kg} \mathrm{DQO} / \mathrm{m}^{3}$ dia. O grande volume dificulta a homogeneização do meio e o controle da temperatura podendo aparecer caminhos preferenciais, reduzindo assim a eficiência (PROCKNOR, 2009).

As diferenças entre a capacidade de tratamento destes sistemas de tratamento aparecem na Tabela 9. 
Tabela 9. Taxa de aplicação das diferentes tecnologias para a digestão de vinhaça.

\begin{tabular}{cc}
\hline Tipo de tecnologia & $\begin{array}{c}\text { Taxa de aplicação } \\
\mathbf{k g D Q O} / \mathbf{m}^{\mathbf{3}} \mathbf{d i a}\end{array}$ \\
\hline Lagoas anaeróbias & 2 a 3 \\
UASB & 8 a 10 \\
IC & 25 a 30 \\
\hline
\end{tabular}

Fonte: Procknor (2009).

A biodigestão modifica as características químicas da vinhaça in natura, principalmente se observam os seguintes efeitos (Tabela 10):

a) elevação do pH até atingir valores neutros;

b) substancial diminuição da DBO e DQO;

c) aumento da quantidade de nitrogênio amoniacal,

c) permanência constante do conteúdo em potássio.

Tabela 10. Características físico-químicas da vinhaça biodigerida - Usina São Martinho.

\begin{tabular}{lcc}
\hline \multicolumn{1}{c}{ Parâmetro } & $\begin{array}{c}\text { Vinhaça } \\
\text { (antes da biodigestão) }\end{array}$ & $\begin{array}{c}\text { Vinhaça } \\
\text { (depois da biodigestão) }\end{array}$ \\
\hline $\mathrm{pH}$ & 4,0 & 6,9 \\
$\mathrm{DQO}(\mathrm{mg} / \mathrm{l})$ & 29.000 & 9.000 \\
Nitrogênio total $(\mathrm{mg} / \mathrm{l})$ & 550 & 600 \\
Nitrogênio Amoniacal $(\mathrm{mg} / \mathrm{l})$ & 40 & 220 \\
Fósforo $\mathrm{P}_{2} \mathrm{O}_{5}(\mathrm{mg} / \mathrm{l})$ & 17 & 32 \\
Sulfato $(\mathrm{mg} / \mathrm{l})$ & 450 & 32 \\
Potássio $\mathrm{K}_{2} \mathrm{O}(\mathrm{mg} / \mathrm{l})$ & 1400 & 1400 \\
\hline
\end{tabular}

Fonte: Cortez et al. (1998).

\subsubsection{O biogás de vinhaça}

Segundo Pompermayer e Paula (2000), a proporção em volume de $\mathrm{CH}_{4}$ presente no biogás produzido a partir de vinhaça é de 55 a $65 \%$, e o restante esta constituído principalmente por $\mathrm{CO}_{2}$. A Usina São Martinho (2013) informa que o valor obtido no seu biodigestor é próximo a $50 \%$ em $\mathrm{CH}_{4}$. A composição do biogás resultantes da digestão de resíduos orgânicos em geral aparece na Tabela 11.

Tabela 11. Composição do biogás em geral

\begin{tabular}{lc}
\hline \multicolumn{1}{c}{ Gases } & Porcentagem $(\boldsymbol{\%})$ \\
\hline Metano $\left(\mathrm{CH}_{4}\right)$ & $50-80$ \\
Dióxido de Carbono $\left(\mathrm{CO}_{2}\right)$ & $25-40$ \\
Nitrogênio $(\mathrm{N})$ & $0,5-2,5$ \\
Oxigênio $(\mathrm{O})$ & $0,1-1$ \\
Acido sulfídrico $\left(\mathrm{H}_{2} \mathrm{~S}\right)$ & $1-2$ \\
Hidrogênio $(\mathrm{H})$ & $1-2$ \\
\hline
\end{tabular}

Fonte: Coelho et al. (2004). 
O Poder Calorífico Inferior (PCI) do biogás é variável dependendo da concentração de metano. Normalmente chega a $60 \%$ do PCI do gás natural de aproximadamente $40 \mathrm{MJ} / \mathrm{Nm}^{3}$ (SGC, 2012).

O biogás é um gás corrosivo, exigindo cuidados especiais com os materiais empregados nos equipamentos utilizados. Esta característica é consequência da presença de sulfeto de hidrogênio $\left(\mathrm{H}_{2} \mathrm{~S}\right)$. Na combustão do biogás, este sulfeto é oxidado e transformado em dióxido de enxofre $\left(\mathrm{SO}_{2}\right)$. A amônia, também presente no biogás em baixas concentrações, é corrosiva para o cobre e pode emitir como produto da sua combustão os óxidos de nitrogênio $\left(\mathrm{NO}_{\mathrm{x}}\right)$

\subsubsection{Limpeza, compressão e armazenamento de biogás}

A presença de substâncias não combustíveis no biogás, como a água e o dióxido de carbono prejudica o processo de queima, tornando-o menos eficiente. Estas substâncias absorvem parte de energia gerada. Além destes, também há a presença de $\mathrm{H}_{2} \mathrm{~S}$ que pode acarretar corrosão, diminuindo tanto o rendimento, como a vida útil dos equipamentos utilizados. A maioria dos digestores anaeróbios produz um biogás que contém entre 0,3 a 2\% de $\mathrm{H}_{2} \mathrm{~S}$, observando-se também a presença de traços de nitrogênio e hidrogênio (COELHO et al., 2004). Dependendo da aplicação é recomendável a purificação do biogás removendo o $\mathrm{H}_{2} \mathrm{~S}$, o $\mathrm{CO}_{2}$ e a umidade. As práticas mais utilizadas são:

- Remoção de umidade: Pode ser feita por condensação, com glicóis, com sílica gel, etc. Dependendo da utilização final do gás será estabelecido o grau de umidade aceitável.

- $\quad \operatorname{Remoção~de~} \mathrm{CO}_{2}$ : Existe uma variedade de processos de remoção do $\mathrm{CO}_{2}$ presente no gás natural utilizado pelas indústrias petroquímicas, podendo ser por absorção física e química, adsorção em uma superfície contínua, separação por membranas, separação criogênica e a partir de conversão química.

- Remoção de $\mathrm{H}_{2} \mathrm{~S}$ : Os principais processos de remoção de $\mathrm{H}_{2} \mathrm{~S}$ utilizados podem ser biológicos ou químicos.

- Remoção de Partículas: Os tipos mais comuns de lavadores são os lavadores tipo torre, centrífugos e Venturi.

Uma vez extraído o metano do biogás, este não pode ser facilmente armazenado e nem liquefeito à pressão e temperatura ambiente. Para ser transportado e utilizado como combustível para veículos, o metano é armazenado em botijões de aço, com uma pressão de 200 bar. 


\subsubsection{Tecnologias de conversão energética do biogás}

Existem diferentes tecnologias de conversão energética do biogás, estando cada uma delas em diferentes estágios de desenvolvimento ou comercialização. A seguir são resumidas as características mais importantes de cada tecnologia disponível:

- Motor de combustão interna alternativo: São máquinas simples e robustas, sendo os equipamentos mais utilizados para queimar biogás por sua flexibilidade. Podem utilizar diversos tipos de combustíveis líquidos ou gasosos tais como óleo diesel, óleo pesado, gás natural, biogás ou ainda uma mistura deles. Os motores diesel e Otto são facilmente adaptados para biogás, mas atualmente já são preparados para queimar biogás com diferentes teores de metano, dióxido de carbono e ácido sulfídrico. Normalmente são aplicados para fornecer pequenas e médias potencias elétricas, da ordem de centenas de $\mathrm{kW}$ até dezenas de MW. A eficiência dos motores ${ }^{22}$ praticamente não é alterada com as condições ambientais como o são as turbinas a gás (PECORA, 2006). O problema desta opção é seu consumo de óleo lubrificante e as manutenções frequentes.

- Caldeiras: A adaptação desses equipamentos para uso do biogás pode ser realizada através de pequenas modificações. Os níveis de umidade do gás devem ser controlados com a instalação de purgadores e linhas de condensado para impedir danos aos equipamentos e problemas na operação das caldeiras. Para a adaptação das caldeiras para à queima do biogás deve-se aumentar a vazão de combustível, uma vez que o biogás possui menor quantidade de metano que o gás natural. A instabilidade da chama - decorrente da menor concentração de metano e das flutuações na composição do biogás - pode ser controlada com a instalação de sensores ultravioletas que monitoram a chama da caldeira impedindo que esta apague, ou com o uso de um sistema de combustível auxiliar. A corrosão devido à umidade e ao ácido sulfídrico presentes no biogás é outro problema para as caldeiras. O revestimento do préaquecedor e da chaminé com material anticorrosivo, o controle da temperatura dos gases de exaustão acima do ponto de orvalho e a circulação adequada da água podem reduzir os efeitos corrosivos (USEPA, 1991).

- Microturbinas a gás: As microturbinas são fabricadas na faixa de potência de 15 a $300 \mathrm{~kW}$. O conteúdo de metano não afeta a eficiência, desde que o teor volumétrico do $\mathrm{CH}_{4}$

\footnotetext{
${ }^{22}$ Com gás natural a eficiência é de $40 \%$ e com biogás pouco mais de 30\%. (COELHO et al., 2006).
} 
seja superior a 35\% (PECORA, 2006). O custo por potência instalada é consideravelmente superior ao motor.

- Uso veicular do biogás. Uma vez extraído do biogás, o metano pode ser utilizado em motores de veículos nas mesmas condições que o gás natural. Existe a possibilidade de transformar veículos de gasolina e diesel para seu funcionamento com metano fazendo modificações no tanque de armazenagem de combustível, no motor e no chassi. Para o armazenamento o gás, este é comprimido de 204 a 245 bar antes de ser bombeado para os cilindros de alta pressão. Os motores de ciclo Otto que utilizam gasolina podem ser facilmente modificados para o funcionamento com metano, trocando o sistema de injeção de combustível e regulando os sensores e computadores que ajustam a mistura de ar e combustível. No caso dos motores diesel, existem duas possibilidades de modificação para operar com metano: operação bi-combustível (diesel-metano) com ignição por injeção de combustível piloto, e funcionamento unicamente a gás utilizando ignição por faísca. No primeiro caso, a tecnologia diesel dual-fuel (dff) utiliza o diesel como chama piloto e o gás natural como combustível principal, sendo necessária a modificação do sistema de injeção eletrônica de combustível. No segundo caso o motor tem que ser transformado para ciclo Otto, retirando os injetores, colocando velas de ignição e um gás carburador, além de diminuir a taxa de compressão.

\subsubsection{Implantação da tecnologia e estudos de caso}

Pinto (1999) relata que a primeira experiência de grande porte no Brasil com a digestão anaeróbia da vinhaça foi realizada na Destilaria Central Jacques Richer, em Campos/RJ, que tinha uma produção de $180 \mathrm{~m}^{3}$ de álcool por dia. Segundo Campos (1981) o biodigestor de $330 \mathrm{~m}^{3}$ funcionou até 1982, obtendo uma média de eliminação de DQO de 62\%, com 16,5 litros de biogás por cada litro de vinhaça, com $55 \%$ de $\mathrm{CH}_{4}$, com um tempo de retenção de 10 dias. O gás foi utilizado na caldeira sem modificação dos queimadores, originalmente projetados para trabalhar com óleo combustível. O biodigestor trabalhava a $35^{\circ} \mathrm{C}$ e foi inoculado com esterco de boi que durante 60 dias foi adaptado à vinhaça.

Em 1981, o Instituto de Pesquisas Tecnológicas (IPT) iniciou uma experiência na unidade Penedo Agroindustrial Destilaria, em Penedo/AL, em que se pesquisou a digestão anaeróbia da vinhaça a $32^{\circ} \mathrm{C}$, utilizando-se dois biodigestores de fluxo ascendente com $11 \mathrm{e}$ $24 \mathrm{~m}^{3}$. A Confederação Nacional de Indústria (CNI) publicava em 1982 (CNI apud PINTO,1999) que a produção média de gás foi de 13,1 litros por litro de vinhaça, com $65 \%$ de $\mathrm{CH}_{4}$, um tempo de retenção de 1,5 dias e remoção de $95 \%$ da DQO. 
Em 1984, a CODISTIL - com tecnologia holandesa para digestores anaeróbios UASB, chamada METHAX BIOPAQ - instalou estes digestores na Usina São Luís, em Pirassununga/SP, e na Destilaria São João. Segundo Pinto (1999), na Usina São Luís o projeto foi desativado pouco tempo depois, mas a Destilaria São João, cuja capacidade é de $300 \mathrm{~m}^{3}$ de álcool por dia, produzindo $3.000 \mathrm{~m}^{3}$ de vinhaça, manteve em operação uma planta de biodigestão anaeróbia de vinhaça até o final de 1997. O projeto era parcialmente financiado pelo Governo Brasileiro e a ideia era criar uma demonstração do funcionamento da tecnologia (CORTEZ, 1998). Esta planta era equipada com um reator UASB, cuja capacidade era de $1500 \mathrm{~m}^{3} /$ dia, com carga efetiva de cerca de $1.000 \mathrm{~m}^{3} /$ dia e remoção de $85 \%$ da DQO, operando em temperatura de $35^{\circ} \mathrm{C}$ e sendo efluente usado como fertilizante no canavial. $\mathrm{O}$ biogás gerado, que tinha um teor de $70 \%$ de metano, era purificado até $98 \%$ de metano, comprimido a 220 bar e armazenado em cilindros de $400 \mathrm{Nm}^{3}$ de capacidade. Segundo Barberi (1998), a produção média global foi de $4.274 \mathrm{Nm}^{3} /$ dia, com um pico de 7.190 $\mathrm{Nm}^{3} /$ dia na safra 92/93. O metano comprimido era utilizado para movimentar 41 veículos da destilaria que foram convertidos para o seu uso, sendo $50 \%$ da frota de caminhão e $40 \%$ da frota de veículos utilitários; a maioria era movida a álcool anteriormente.

Segundo Barberi (1998) o rendimento dos veículos movidos a gás metano superou o dos movidos a álcool e dos caminhões a diesel, uma vez efetuadas as mudanças necessárias para sua adaptação. Porém, o diesel não podia ser substituído nos motores de alta potência dos treminhões $(240 \mathrm{CV})$, utilizados pela indústria para o transporte da cana. A Destilaria São João resolveu suspender o programa de uso do metano a partir da safra de 1996/1997. Isto porque, no caso dos motores movidos a álcool, não existia interesse em de substituir este combustível que é produzido pela destilaria. Para os motores a diesel dos treminhões, os resultados não foram satisfatórios, sendo constatada muita perda de potência e aumento da frequência de manutenção. Estes problemas só podiam ser sobrepassados mudando a estrutura do motor.

Na Usina São Martinho, em Pradópolis/SP, encontra-se um exemplo de digestão anaeróbia da vinhaça que funciona até os dias de hoje. Esta usina de grande porte tem uma capacidade de moagem de 8,5 milhões de toneladas de cana por safra (SÃO MARTINHO, 2013). Com uma produção de $20.000 \mathrm{~m}^{3}$ de vinhaça por dia, este resíduo possui uma concentração de sólidos de $2,6^{\circ}$ Brix e uma DQO que varia entre de 20 a 30 g/l. Com uma temperatura superior a $60^{\circ} \mathrm{C}$ na tubulação de saída, é retirada uma quantidade próxima a $45 \mathrm{~m}^{3} / \mathrm{h}$ de vinhaça in natura que é armazenada temporariamente em um tanque de 
equalização de $800 \mathrm{~m}^{3}$. Deste depósito passa a um tanque de mistura onde é diluído numa vazão de $190 \mathrm{~m}^{3} / \mathrm{h}$ proveniente do biodigestor, de $5.000 \mathrm{~m}^{3}$ de capacidade. O controle da temperatura da vinhaça na entrada do biodigestor é feita através de dois trocadores de calor, um que utiliza água para resfriamento e outro que emprega a própria vinhaça como fonte de calor. Este processo de controle é automatizado e mantém uma temperatura no entorno de $55^{\circ} \mathrm{C}$ no interior do biodigestor. A vinhaça é injetada no fundo do biodigestor, onde atravessa uma camada de lodo de aproximadamente $1 \mathrm{~m}$. Na parte superior, a vinhaça é direcionada para dois decantadores, que recuperam o lodo e o recirculam no biodigestor. O esquema do processo descrito é representado na Figura 16.

O biogás, com um conteúdo de metano em volume de 50\% segundo foi informado pelos técnicos (SÃO MARTINHO, 2013), é capturado na parte superior e direcionado para um sistema de limpeza de umidade antes de ser encaminhado para o secador tipo spray drier, onde o poder calorífico do biogás é aproveitado para a secagem de levedura. Este sistema não incorpora a limpeza de $\mathrm{H}_{2} \mathrm{~S}$, pois sua produção é inferior a $1 \%$ em volume (SÃO MARTINHO, 2013). Dependendo da produção de levedura, o biogás produzido não é suficiente para sua secagem, tendo que ser utilizado vapor. O sistema de exaustão do secador não possui tratamento dos gases.

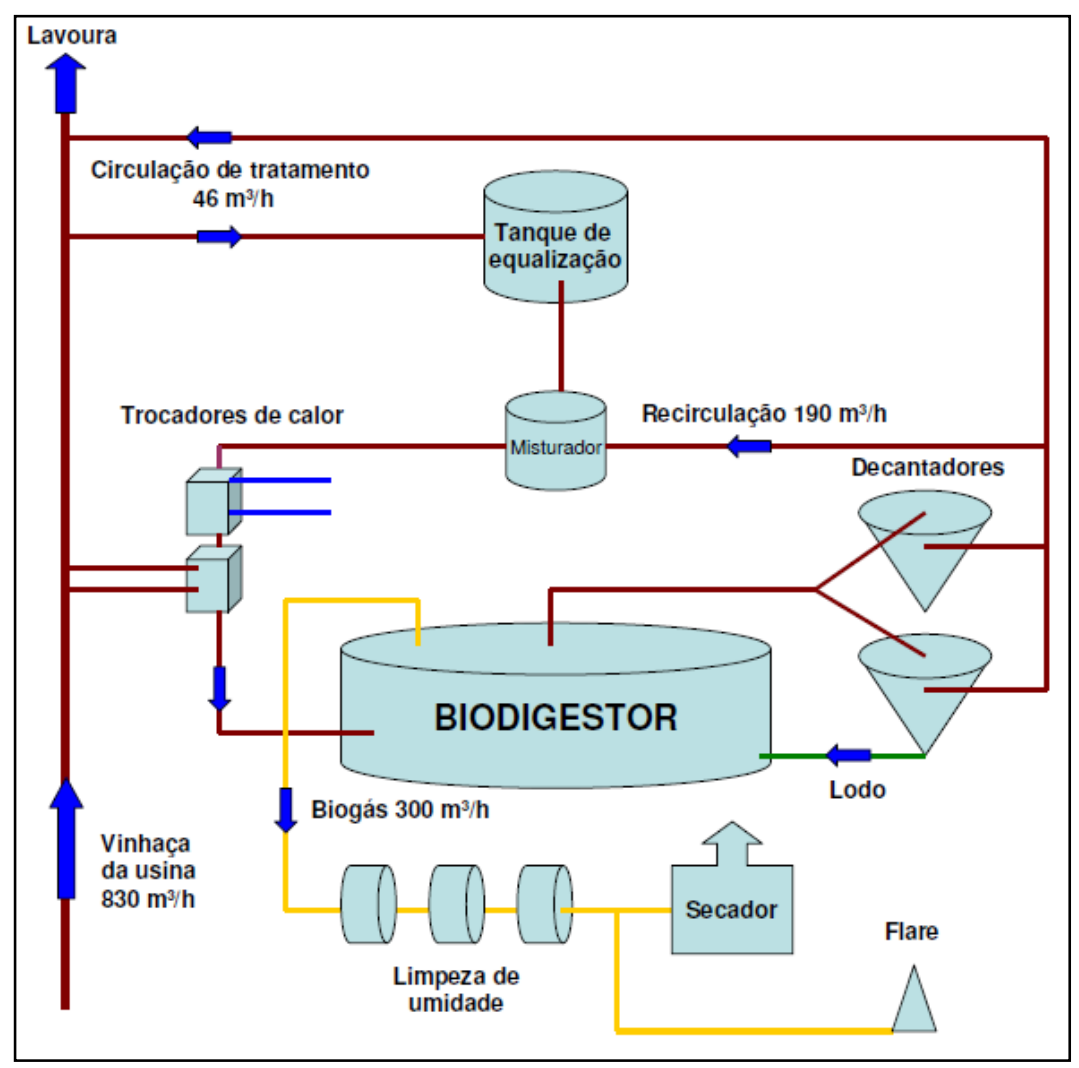

Figura 16. Esquema do processo do biodigestor da Usina São Martinho.

Fonte: Autor, a partir de visita de campo (2013). 
O maior problema de operação deste sistema é o controle do $\mathrm{pH}$, que limita a carga orgânica introduzida. A diminuição do $\mathrm{pH}$ pode ser realizada através do aumento da recirculação (diminuição da carga orgânica), ou introduzindo sosa cáustica, mas o uso deste insumo é limitado pelo custo. Outro fator para a baixa carga orgânica que suporta o biodigestor é devida à carência de micronutrientes contidos na vinhaça que limita a produção e a atividade dos microrganismos. Igualmente, a adição destes micronutrientes é inviabilizada pelos custos. Quando são aplicados antibióticos durante o processo de produção do etanol, a operação consiste em evitar a entrada da vinhaça no biodigestor durante 48 a 72 h depois da centrifugação das dornas.

Outro sistema recentemente instalado é a lagoa de alta taxa instalada na Usina Ester em Cosmópolis/SP. A empresa OMNIS Biotechnology S.A. desenvolveu este projeto de escala piloto com o financiamento da Companhia Paulista de Força e Luz (CPFL), empresa de distribuição de energia do interior de São Paulo.

Segundo os técnicos do sistema (OMNIS, 2013), a Usina Ester produz $600 \mathrm{~m}^{3} / \mathrm{h} \mathrm{de}$ vinhaça com 20 a $60 \mathrm{~kg}$ de $\mathrm{DQO} / \mathrm{m}^{3}$. Não existe tratamento químico da vinhaça antes da entrada no biodigestor, mas é resfriada da temperatura de chegada de $65^{\circ} \mathrm{C}$ até $50^{\circ} \mathrm{C}$ por meio de uma coluna de resfriamento, chegando ao reator a $38^{\circ} \mathrm{C}$. O esquema do processo é representado na Figura 17.

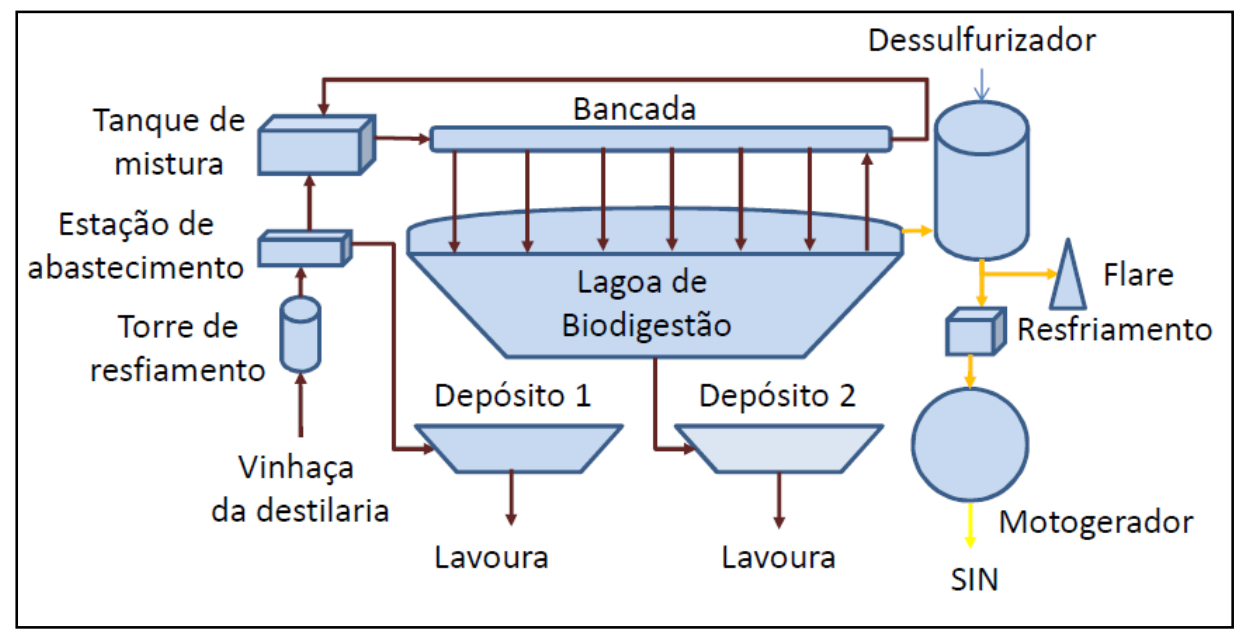

Figura 17. Esquema do processo do biodigestor da Usina Ester.

Fonte: Autor, a partir de visita de campo (2013).

A vinhaça resfriada passa para um tanque onde é misturada com vinhaça proveniente do reator, sendo diluída nesta com a consequente diminuição de temperatura e aumento do $\mathrm{pH}$. Depois, a vinhaça é injetada na parte inferior da lagoa em vários pontos (Figura 18). 


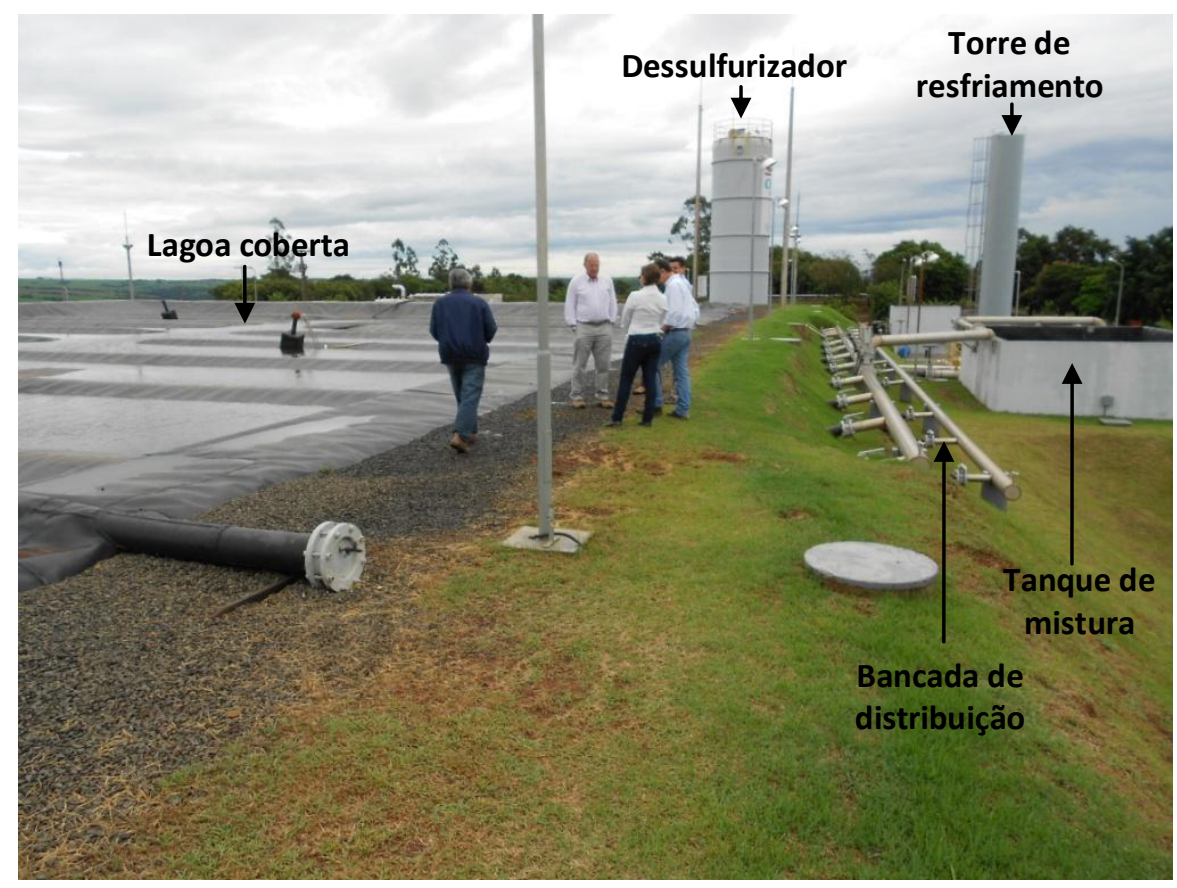

Figura 18. Imagem do sistema de biodigestão da Usina Ester.

Fonte: Autor, visita de campo (2013).

Como foi mencionado, o tipo de biodigestor utilizado é uma lagoa de alta taxa, com um volume de $15.000 \mathrm{~m}^{3}$, de dimensões $60 \times 40 \times 7 \mathrm{~m}$ e uma capacidade de tratamento de 2 $\mathrm{kgDQO} / \mathrm{m}^{3}$ dia. Com um tempo de residência de 12 dias foi informada uma eficiência de remoção de DQO em 95\% (OMNIS, 2013). Com relação à produção de biogás, o biodigestor consegue 0,2 $\mathrm{m}^{3}$ de biogás/ $\mathrm{kgDQO}$, variando de 4 a $12 \mathrm{~m}^{3}$ de biogás/ $\mathrm{m}^{3}$ de vinhaça, mas a empresa não informou a proporção de metano presente. O biogás passa por um processo biológico de dessulfurização, para ser resfriado e utilizado em um motogerador de $1 \mathrm{MW}_{\mathrm{e}}$. Segundo a OMNIS (2013), a lagoa tem potencial para gerar combustível para um sistema de até 1,5 $\mathrm{MW}_{\mathrm{e}}$. O consumo das cargas internas do sistema é de $4 \%$ da energia gerada.

Para a operação, é necessária uma comunicação entre a usina e a central de controle do biodigestor para alertar sobre o uso de antibióticos nas dornas. Durante as três safras de funcionamento, só teve um evento onde foi prejudicada a produção de biogás e ocorreu por 3 dias quando foram detectadas 10 ppm de antibiótico termoestável na vinhaça.

O modelo de negócio adotado consiste em que a usina leve uma porcentagem do lucro da venda de energia elétrica pelo fornecimento da vinhaça.

A Cetrel, em parceria com o Grupo JB, inaugurou em 2012 uma termoelétrica a partir de biogás de vinhaça. As instalações estão localizadas na unidade industrial da Companhia Alcoolquímica Nacional, usina do Grupo JB, em Vitória de Santo Antão/PE. Foram 
investidos R \$ 15 milhões e a potência instalada é de 0,85 MW com motogeradores tratando aproximadamente mil metros cúbicos de vinhaça/dia (DIARIO DE PERNAMBUCO, 2012) ${ }^{23}$.

O empreendimento de maior porte na atualidade é o da empresa GEO-Energética, que tem 4 MW elétricos instalados no Estado de Paraná. Depois de um amplo trabalho de pesquisa na geração de biogás, $\mathrm{R} \$ 55$ milhões de investimento e um difícil start-up no ano 2012, a planta está gerando energia elétrica firme (365 dias por ano), a partir de biogás de vinhaça e outros resíduos sólidos orgânicos do setor, sendo utilizados bagaço, palha e torta de filtro, sendo esta sua grande novidade em comparação aos outros sistemas que só utilizam a vinhaça (GEO-ENERGÉTICA, 2014) ${ }^{24}$.

\subsection{Combustão da vinhaça}

\subsubsection{Características da vinhaça como combustível}

A vinhaça in natura contém aproximadamente $95 \%$ de água, o que torna sua combustão impossível. Portanto, para viabilizar a queima é necessário aumentar a sua concentração até atingir suficiente teor de sólidos.

Segundo Rocha (2009), testes realizados indicam que a partir de $60 \%$ de sólidos a vinhaça já possui um poder calorífico suficiente para a queima. Por outro lado, determinar o teor de sólidos que torna a combustão economicamente viável deve ser considerado o balanço entre o consumo de energia para a concentração e a energia produzida pela incineração.

Avram et al. (2006) mediram a composição elementar, teor de água, cinzas e poderes caloríficos superior e inferior para uma vinhaça concentrada proveniente de mosto misto (Tabela 12). Com já foi mencionado, exististe uma variação importante entre as vinhaças produzidas nas destilarias e, por este motivo, o poder calorífico e a viscosidade dependerão do teor de sólidos e da proporção entre os constituintes (ROCHA, 2009).

Tabela 12. Parâmetros da vinhaça concentrada

\begin{tabular}{cccc}
\hline Parâmetro & $\begin{array}{c}\text { Vinhaça seca livre de } \\
\text { cinza }\end{array}$ & Vinhaça seca & $\begin{array}{c}\text { Vinhaça em forma de } \\
\text { combustível líquido 65 } \mathbf{~} \mathbf{B x}^{\mathbf{0}}\end{array}$ \\
\hline Carbono \% peso & 41,19 & 32,85 & 21,36 \\
Hidrogênio \% peso & 6,47 & 5,16 & 3,35 \\
Enxofre \% peso & 1,60 & 1,28 & 0,83 \\
Oxigênio \% peso & 48,30 & 38,52 & 25,04
\end{tabular}

\footnotetext{
${ }^{23}$ DIARIO DE PERNAMBUCO. Projeto em Vitória de Santo Antão tem investimento de R\$ 15 milhões e vai gerar 612 MWh/mês. Abril de 2012. Disponível em: < http://pedesenvolvimento.com/2012/04/05/energia-apartir-da-vinhaca/>. Acesso em: $10 \mathrm{Dez} 2014$.

${ }^{24} \mathrm{http}: / / \mathrm{www}$.geoenergetica.com.br/
} 


\begin{tabular}{cccc}
\hline Parâmetro & $\begin{array}{c}\text { Vinhaça seca livre de } \\
\text { cinza }\end{array}$ & Vinhaça seca & $\begin{array}{c}\text { Vinhaça em forma de } \\
\text { combustível líquido 65 }{ }^{\mathbf{B x}}\end{array}$ \\
\hline Nitrogênio \% peso & 2,44 & 1,95 & 1,26 \\
Cinzas \% peso & 0,00 & 20,24 & 13,16 \\
Água \% peso & 0,00 & 0,00 & 35,00 \\
PCS kJ/kg & 16.971 & 13.534 & 8.797 \\
PCI kJ/kg & 15.515 & 12.373 & 7.167 \\
\hline
\end{tabular}

Fonte: Avram et al. (2006).

\subsubsection{Características gerais do processo}

A combustão ou incineração da vinhaça é uma tecnologia que permite uma pratica eliminação dos potenciais impactos negativos da fertirrigação ao exaurir completamente o volume e a matéria orgânica do efluente, restando as cinzas potássicas que podem ser usadas como fertilizante.

O diagrama de fluxo da Figura 19, mostra o esquema básico de uma instalação térmica de concentração e combustão de vinhaça e geração de energia elétrica.

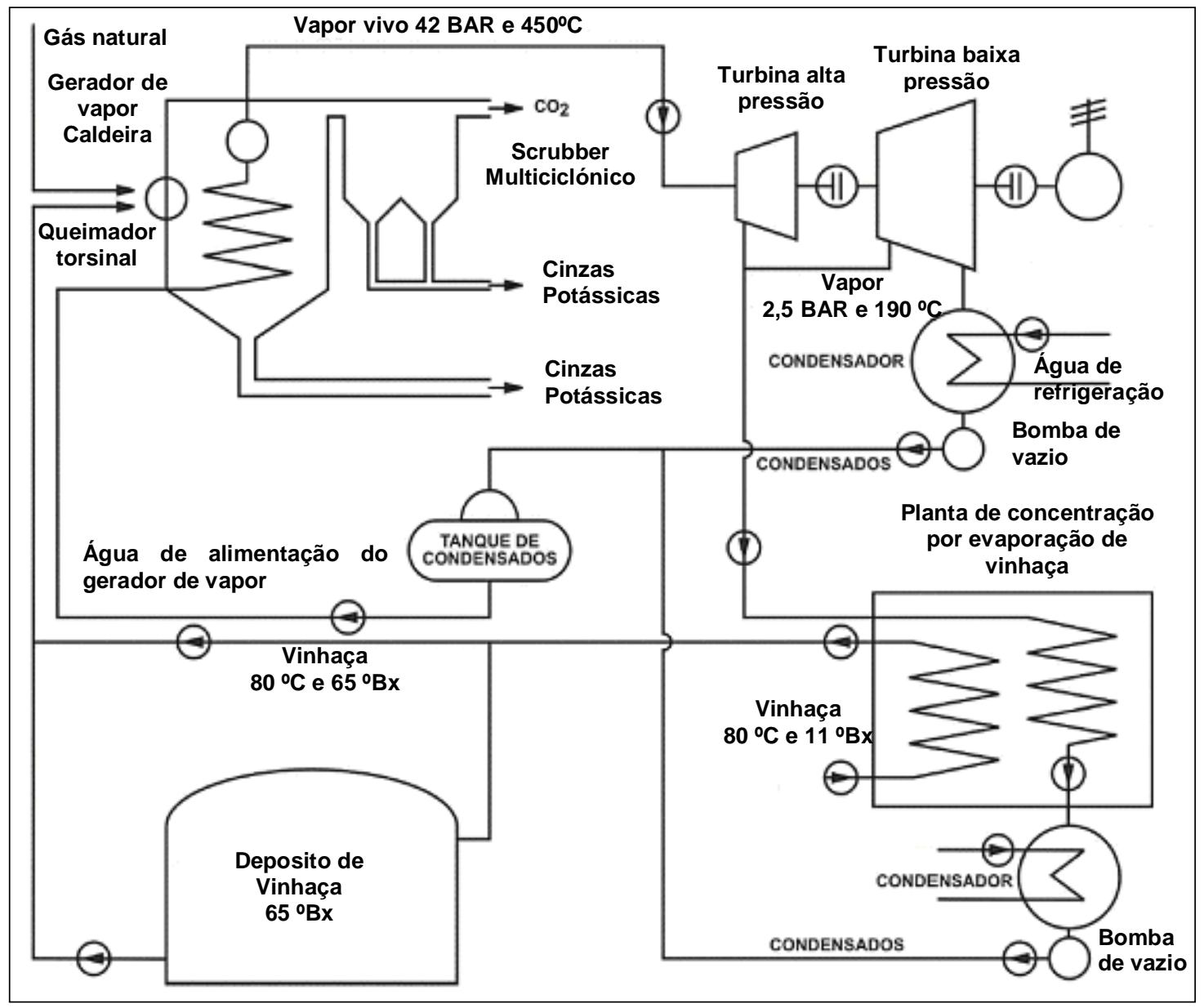

Figura 19. Esquema básico de Instalação Térmica de Concentração para Combustão de Vinhaça e Geração de Energia Elétrica. Fonte: Adaptado de Perera (2009). 
Uma característica importante da técnica da incineração de vinhaça é que há necessidade de um combustível suporte para dar estabilidade à chama e conseguir sua queima total. Cortez e Perez (1997) trabalharam com vinhaça concentrada misturada óleo combustível, mas existem diferentes alternativas de combustível suporte a ser usadas, como gás natural ou biomassa solida pulverizada. Na procura de evitar o uso de combustíveis fósseis e de utilizar os coprodutos da usina, pode ser proposto o uso de bagaço ou de palha pulverizados (SAACKE, 2013) ${ }^{25}$. Atualmente, só é utilizado gás natural nos incineradores de vinhaça devido a diversos problemas técnicos e econômicos que serão comentados no Capítulo 8 de resultados e discussão.

\subsubsection{Tecnologia de combustão de vinhaça}

A vinhaça in natura contém entre 3 a 5\% de sólidos (CETESB, 1982), sendo água o restante do volume. Para alcançar um valor mínimo requerido para a combustão estável, o efluente deve ser concentrado até $60-70 \%$ de sólidos por meio de evaporação. Depois a vinhaça concentrada é temporariamente armazenada em um tanque pulmão para assegurar o fornecimento à planta de incineração. Antes de ser atomizada a vinhaça deve ser pré-aquecida a $90^{\circ} \mathrm{C}$ para diminuir sua viscosidade (ROCHA, 2009).

Os líquidos residuais de baixo poder calorífico como a vinhaça, o melaço e o licor negro, podem ser queimados empregando um sistema de combustão com fluxo de vórtice e injeção tangencial, também denominado queimador torsional. Na Figura 20 se mostra este tipo de queimador específico.

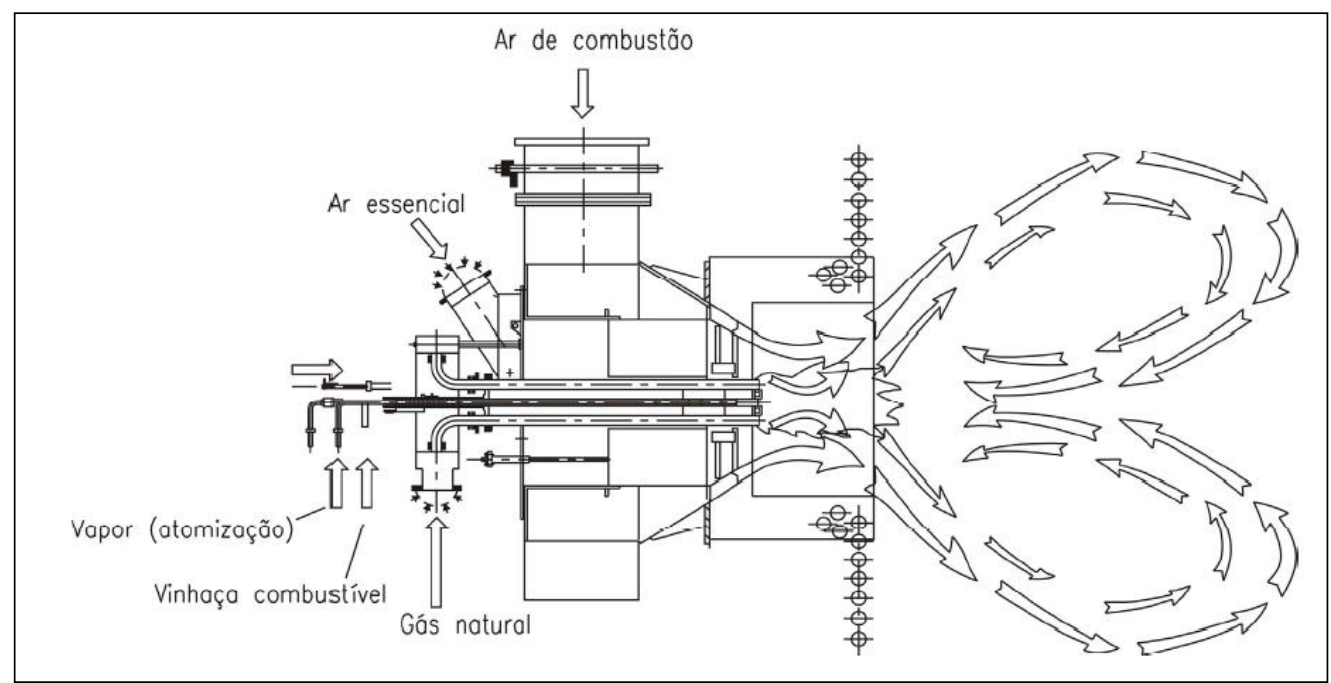

Figura 20. Queimador para queima de gás natural e vinhaça concentrada. Fonte: Schopf e Erbino (2006).

\footnotetext{
${ }^{25}$ SAACKE, comunicação pessoal, 2013.
} 
A combustão se inicia com um combustível líquido ou gasoso de alto poder calorífico até atingir uma temperatura que permita a combustão completa da vinhaça. Injeta-se depois a vinhaça concentrada, reduzindo gradualmente a proporção de combustível auxiliar até que um fluxo mínimo mantenha a estabilidade da chama e a combustão completa. O ar de combustão é tangencialmente subministrado. $\mathrm{O}$ ajuste das proporções das correntes deve ser feito para lograr uma combustão ótima e baixos valores de emissões. Segundo Rocha (2009), a temperatura máxima permitida é $600{ }^{\circ} \mathrm{C}$ pra que as cinzas não atinjam o ponto de fusão, formando um material vítreo que causaria uma a obstrução nos tubos. Os gases de exaustão deverão ser tratados para atingir os valores de emissões permitidos pela legislação ambiental.

A Figura 21 mostra um queimador torsional Saacke para vinhaça concentrada de melaço de soja, modelo SSB de $40 \mathrm{MW}_{\mathrm{t}}$, que emprega óleo combustível pulverizado como combustível auxiliar.

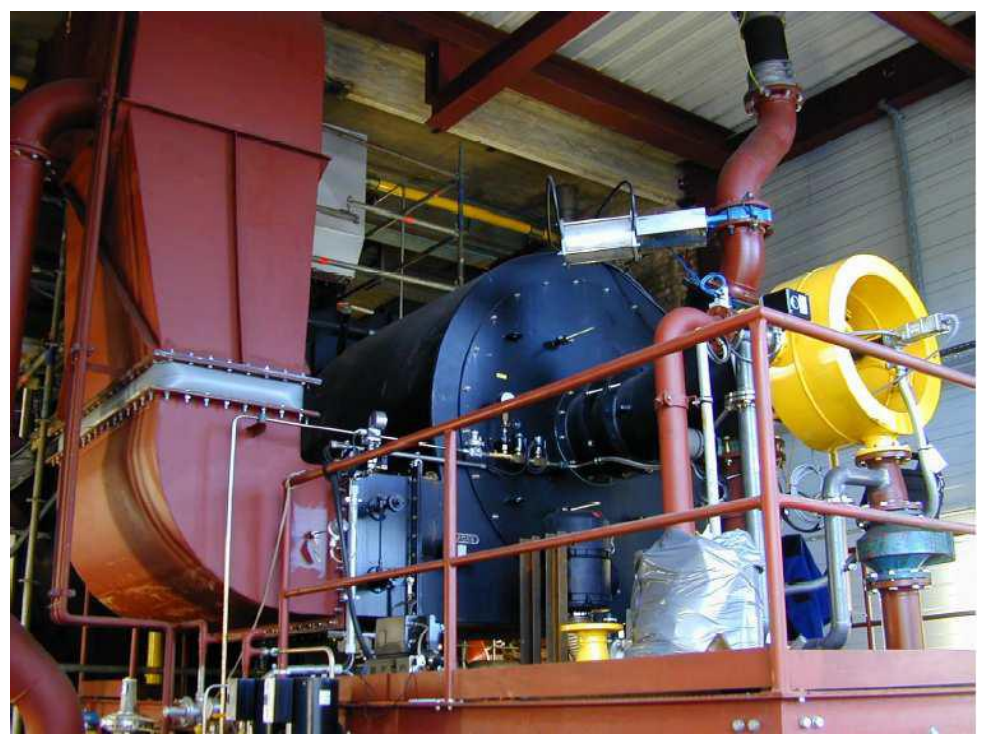

Figura 21. Queimador torsional Saacke para vinhaça concentrada de melaço, modelo SSB de $40 \mathrm{MW}_{\mathrm{t}}$. Fonte: SAACKE (2012)

Segundo Freire e Cortez (2000) outra forma de queimar a vinhaça é através da tecnologia de leito fluidizado, baseada fundamentalmente na circulação de sólidos juntamente com o fluido. Estes autores indicam que esta tecnologia não obteve êxito na incineração de vinhaça porque as suas propriedades críticas dificultaram muito a queima, além do elevado custo da planta.

O vapor saturado que sai da caldeira pode ser usado diretamente para evaporação, preaquecimento ou nos processos de destilação. Com a aplicação de um superaquecedor, o vapor superaquecido pode alimentar uma turbina de vapor de contrapressão que aciona um

\footnotetext{
${ }^{26}$ www.saacke.com.br/
} 
gerador elétrico para geração de eletricidade, como pode ser visto na Figura 22. A vantagem deste sistema de cogeração é que o vapor de exaustão da turbina pode ser usado na destilaria e na planta de concentração de vinhaça, após a geração de energia.

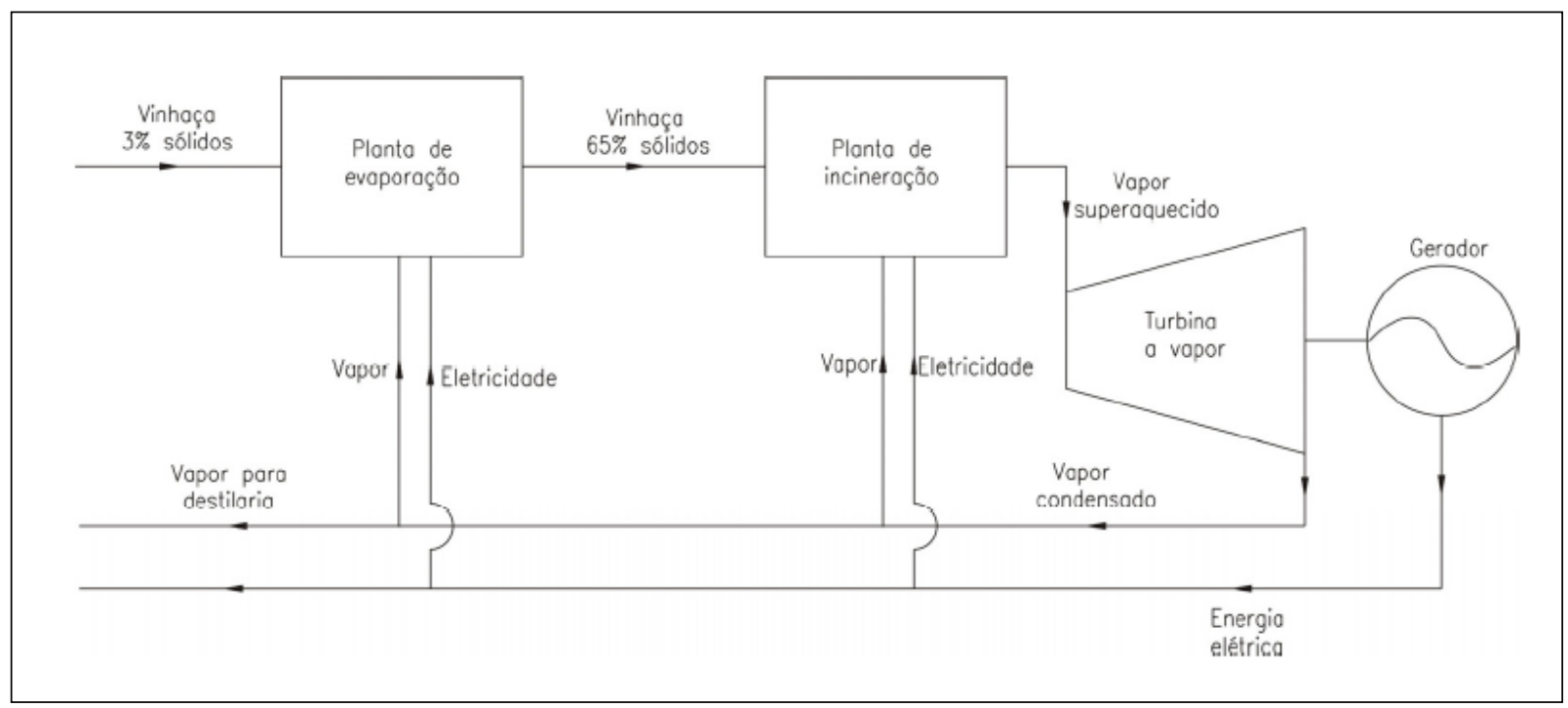

Figura 22. Recuperação de calor e potência na incineração de vinhaça.

Fonte: Rocha (2009).

As cinzas recuperadas podem ser vendidas ou utilizadas pela própria destilaria. Rocha (2009) afirma que as cinzas são diferentes para cada tipo de vinhaça, mas geralmente contém elevada quantidade de sais de potássio ${ }^{27}$, além de outros componentes como óxidos de cálcio $(\mathrm{CaO})$ e de magnésio $(\mathrm{MgO})$ que são solúveis em água e podem ser utilizados como fertilizante.

\subsubsection{Implantação da tecnologia e estudos de caso}

As experiências em laboratório que podem ser destacados são as de Gupta et al. (1968), que conduziram experimentos de queima vinhaça de $30-40^{\circ} \mathrm{Bx}$ em um leito fluidizado e pulverizada em um secador tipo spray drier. De outra forma, Dubey (1974) usou uma fornalha bicombustível com vinhaça a $60^{\circ}$ Bx e bagaço. Cortez e Perez (1997) estudaram a combustão de vinhaça de diferentes concentrações de sólidos e emulsões com óleo combustível.

De experiências de porte industrial, tem-se conhecimento de duas plantas de incineração foram instaladas em Pernambuco há 60 anos, mas ambas fecharam devido a problemas econômicos (MONTEIRO, 1975). Uma planta de combustão de vinhaça foi instalada na Tailândia pela destilaria Bangyikhan em 1986 e operou por 12 anos, até 1998 (NEM, 2007). A

\footnotetext{
${ }^{27}$ Sais de potássio encontradas nas cinzas da combustão de vinhaça: $\mathrm{K}_{2} \mathrm{SO}_{4}, \mathrm{KCl}$ e $\mathrm{K}_{2} \mathrm{CO}_{3}$.
} 
planta de concentração foi projetada pela Vogelbusch e a caldeira de combustão foi projetada pela empresa holandesa NEM. A capacidade da planta era de $6 \mathrm{t} / \mathrm{h}$ de vinhaça concentrada, enquanto seriam produzidos $15 \mathrm{t} / \mathrm{h}$ de vapor saturado. A Figura 23 ilustra a planta de concentração de vinhaça da destilaria Bangyikhan (Tailândia).

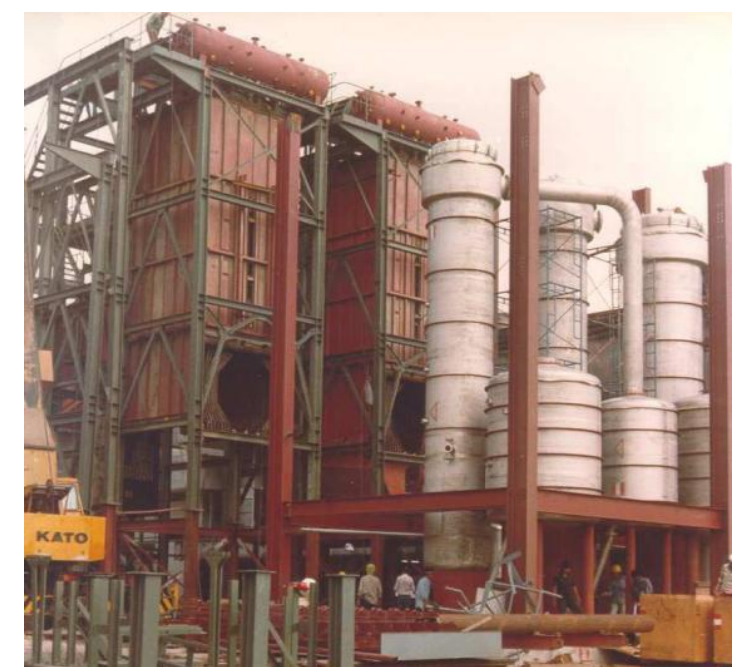

Figura 23. Planta de combustão da vinhaça da destilaria Bangyikhan (Tailândia). Fonte: NEM (2007).

Chaudhari, Mishra e Chandb (2008) apresentam em seu estudo que, na China, um grande número de destilarias usa evaporadores de múltiplo efeito para concentrar os efluentes e efetuar sua incineração, sendo recuperada a maior parte do conteúdo energético.

No Brasil operam atualmente dois sistemas de combustão de vinhaça concentrada em duas plantas da empresa IMCOPA, localizadas nos municípios de Araucária e Cambe do Estado do Paraná (PERERA, 2009). Esta vinhaça e produzida durante a destilação do etanol fabricado com soja.

Tabela 13. Sistemas instalados de combustão de vinhaça no Brasil.

\begin{tabular}{lll}
\hline Localização & Araucária, Paraná, Brasil & Cambe, Paraná, Brasil \\
Aplicação & Gerador de vapor acuo-tubular & Gerador de vapor acuo-tubular \\
Tipo & Desenho para biomassa & Desenho para biomassa \\
Capacidade & $60 \mathrm{t} / \mathrm{h}$ & $40 \mathrm{t} / \mathrm{h}$ \\
Pressão & $42 \mathrm{bar}$ & $42 \mathrm{bar}$ \\
Temperatura do vapor & $400^{\circ} \mathrm{C}$ & $400^{\circ} \mathrm{C}$ \\
Marca do queimador & Saacke GmbH \& Co. KG & Saacke GmbH \& Co. KG \\
Tipo de queimador & $2 \times \mathrm{SSBS}-\mathrm{LCG} 200$ & $\mathrm{SSBS}-\mathrm{LCG} 200$ \\
Potência equivalente & $2 \times 26 \mathrm{MW}$ & $35 \mathrm{MW}$ \\
Data de começo operação & Abril de 2007 & Abril de 2007 \\
\hline Fonte: Pera $(\mathbf{2 0 0 9})$ & &
\end{tabular}


Um projeto semelhante foi instalado em 2012 em Becej, Sérvia, diferenciando-se em relação aos casos brasileiros nas exigências ambientais mais rigorosas e ao investimento significativamente menor (SAACKE, 2013).

\subsection{Resultados da revisão do estado da arte dos tratamento da vinhaça.}

Como foi abordado neste capítulo, existem alternativas para o processamento da vinhaça que melhoram o desempenho ambiental, a gestão do resíduo e permitem o aproveitamento energético. Essas alternativas à fertirrigação com vinhaça in natura se encontram em diferentes níveis de desenvolvimento e de implantação.

O uso da tecnologia da concentração tem-se expandido nos últimos anos devido à necessidade de diminuir os custos de logística na fertirrigação e ao desenvolvimento de equipamentos com melhor desempenho operacional e menor consumo energético.

A biodigestão de vinhaça tem sido pesquisada no Brasil por mais de 30 anos, com experiências de porte industrial como resultado, mas que tem demonstrado na maioria dos casos pouca viabilidade e curta duração. Nos dias de hoje, existe um renovado interesse em aplicar esta tecnologia, sobretudo com o intuito de produzir energia elétrica através do biogás da vinhaça para sua comercialização.

A incineração se encontra em fase experimental, não havendo experiências no Brasil com a vinhaça de etanol de cana. Porém, as possíveis vantagens da recuperação energética e a quase total redução de volume de resíduo, fazem desta tecnologia uma alternativa a considerar.

Toda a informação contida no presente Capítulo fornece a base para a configuração dos cenários que serão definidos no Capítulo 4 e que, subsequentemente, permitirão a realização das comparações entre as tecnologias contempladas. Nos capítulos de balanço energético, impacto ambiental e avaliação econômica se aprofundará no estudo destes aspectos em cada uma das técnicas apresentadas. 


\section{CAPÍTULO 3. DESCRIÇÃO DOS CENÁRIOS A SEREM ANALISADOS PARA TRATAMENTO DA VINHAÇA E SEU BALANÇO ENERGÉTICO.}

No Capítulo 2 desta dissertação foram descritas as diferentes alternativas tecnológicas para o tratamento e processamento da vinhaça, dando um panorama sobre o estado da arte de cada técnica. Em continuidade a esta revisão bibliográfica, as informações levantadas serão utilizadas para configurar as principais características dos cenários que representam a cada possibilidade de processamento.

Para tal, serão analisados cinco cenários, a saber:

- Cenário 0 de referência: Fertirrigação com vinhaça in natura

- Cenário 1: Concentração evaporativa

- Cenário 2: Biodigestão anaeróbia com geração de eletricidade

- Cenário 3: Incineração com geração de eletricidade

- Cenário 4: Biodigestão com concentração e uso veicular

\subsection{Descrição dos cenários}

\subsubsection{Cenário 0 de referência: Fertirrigação com vinhaça in natura}

Neste cenário, analisa-se o armazenamento temporário da vinhaça em lagoas a céu aberto unido ao transporte e distribuição mediante canais e caminhões, para ser aplicada no canavial diretamente ou por aspersão. A caracterização do Cenário 0 é realizada por meio de uma revisão bibliográfica, uma vez que a fertirrigação com vinhaça é um assunto amplamente discutido na indústria e na Academia desde os anos 50, com abundantes referências sobre o uso desta técnica. Na Figura 24, mostra-se um diagrama esquemático do processo de fertirrigação que contém os principais valores assumidos neste estudo. As porcentagens de volume de vinhaça distribuído através de canais e caminhões são extraídas do trabalho de Macedo (2004).

Como mostra a figura, no cenário considerado é utilizado um modelo simplificado constituído por uma única lagoa de armazenamento, onde os caminhões são carregados com $29 \%$ do volume de vinhaça produzido e o restante é transportado por um único canal até o canavial. A realidade é muito mais complexam, pois existe uma infinidade de possibilidades geométricas para o sistema dependendo da localização da usina e das características do território onde se encontra. Normalmente, são encontrados exemplos de sistemas com várias 
lagoas principais e secundárias que se conectam por canais e tubulações pressurizadas, bem como com múltiplos pontos de carregamento para caminhões.

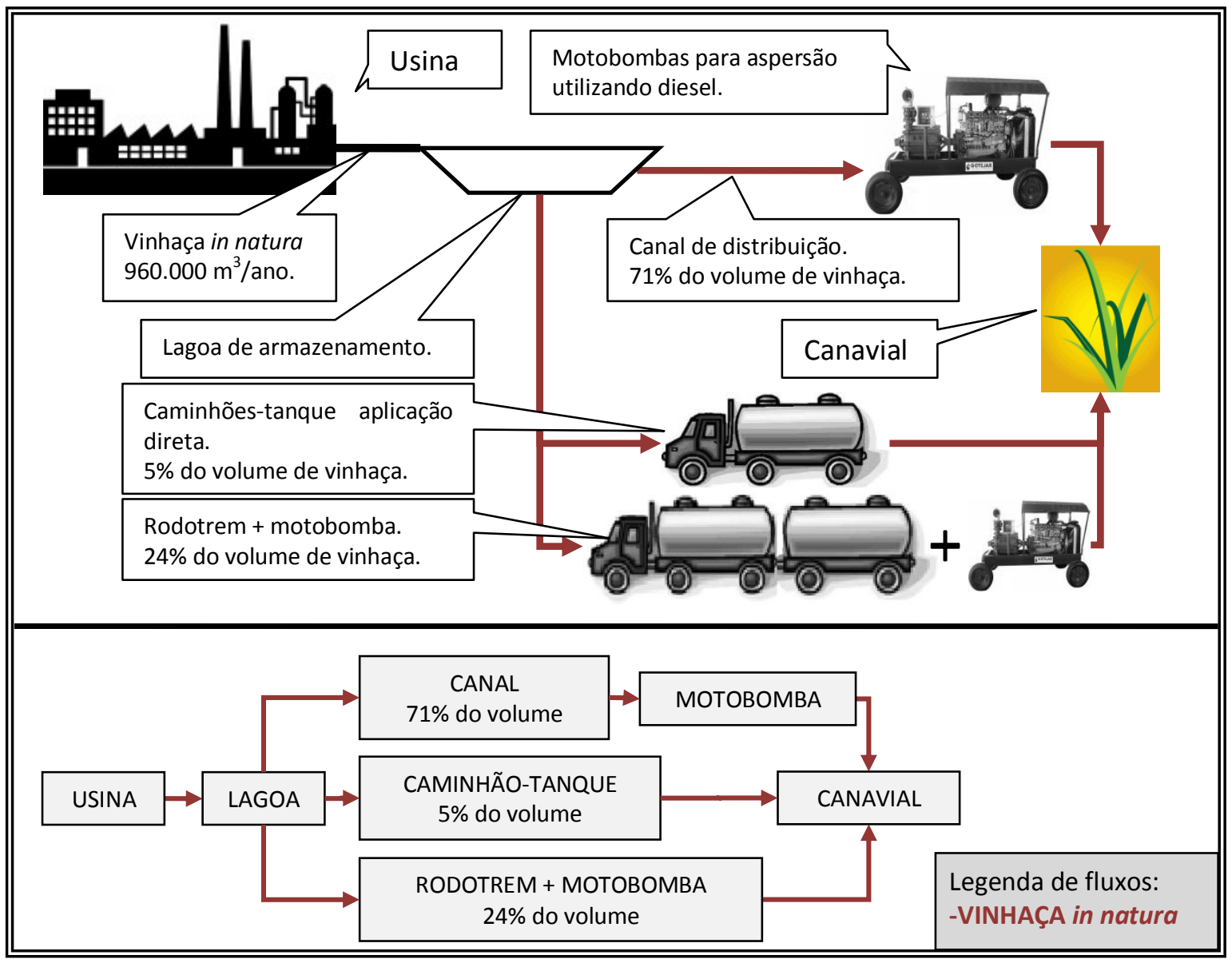

Figura 24. Diagrama ilustrativo e de fluxos do Cenário 0 de referência, Fertirrigação com vinhaça in natura. Fonte: Autor.

Como se especifica na Figura 24, do volume total da vinhaça $71 \%$ é captada do canal por uma motobomba a diesel e aplicada por aspersão, com a possibilidade de usar montagem direta ou carretel enrolador indistintamente. Com relação ao volume que é levado em caminhão, 5\% é aplicado com caminhões-tanque de $15 \mathrm{~m}^{3}$ diretamente sobre o canavial, e $24 \%$ é transportado por rodotrem de $30 \mathrm{~m}^{3}$ para ser aplicado por aspersão com motobomba. Todos estes equipamentos consomem diesel para seu funcionamento nas quantidades que são calculadas no Capítulo 5 de balanço energético.

\subsubsection{Cenário 1: Concentração evaporativa}

No Cenário 1, o volume de vinhaça que é transportado em caminhão no Cenário de referência passa previamente por um processo de concentração (Figura 25). A vinhaça in natura, que possui $4 \%$ de sólidos $\left(4^{\circ} \mathrm{Brix}\right.$ ou $\left.4^{\circ} \mathrm{Bx}\right)$ é concentrada até alcançar $20^{\circ} \mathrm{Bx}$ utilizando um evaporador de múltiplo efeito, para ser posteriormente transportada e aplicada 
com caminhões-tanque diretamente no canavial. O volume de vinhaça transportada no canal não é concentrado.

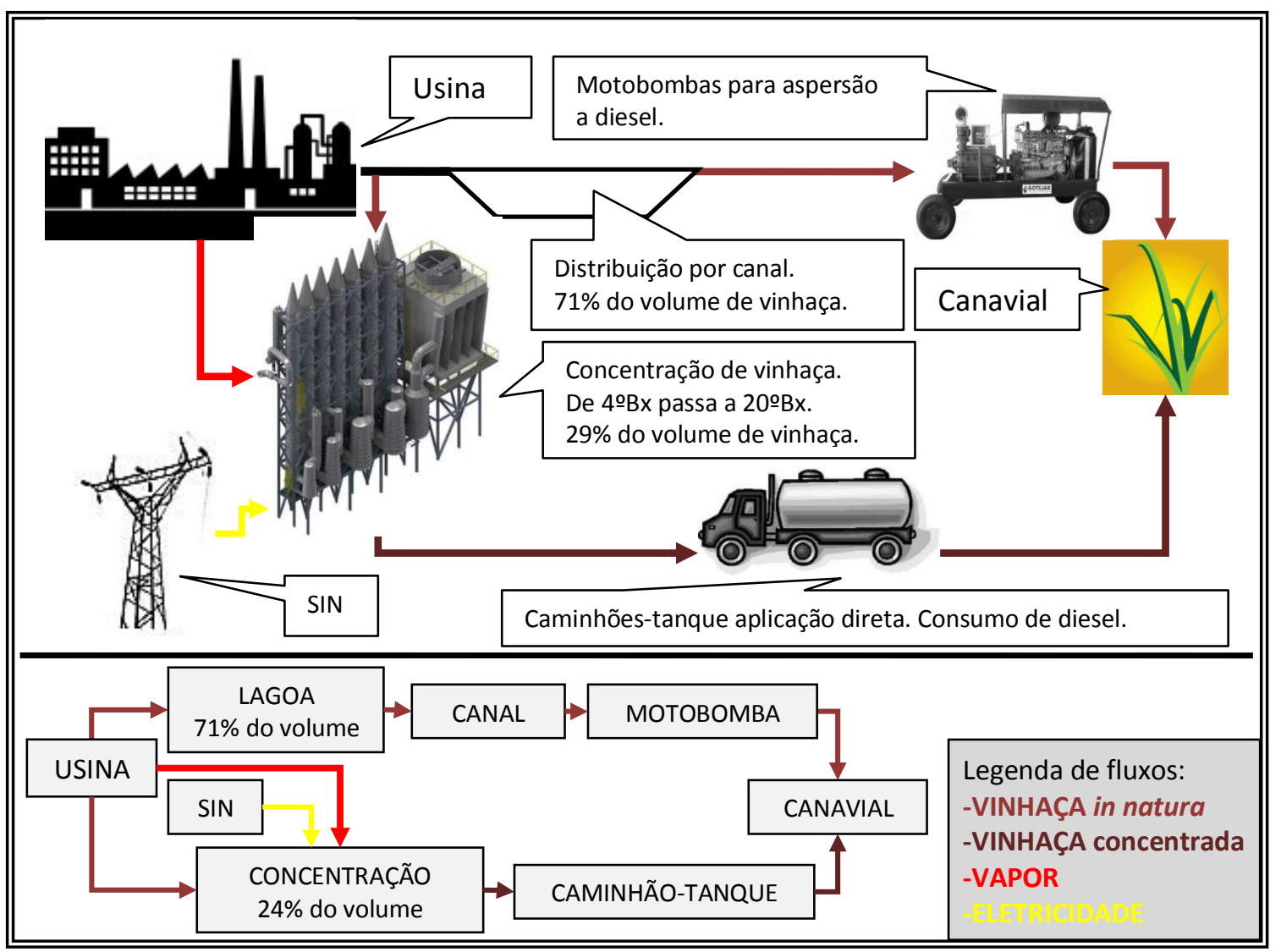

Figura 25. Diagrama explicativo e de fluxos do Cenário 1, Concentração evaporativa. Fonte: Autor.

Neste cenário, são utilizados os dados fornecidos pela Citrotec SL (2013), sendo este o fabricante nacional com maior participação no mercado de concentradores de vinhaça. Como mostrado na Figura 25, para a concentração é preciso o fornecimento de energia térmica, em forma de vapor de processo, além de eletricidade. Ambos os insumos são fornecidos pelo sistema de cogeração da usina, mas considera-se que a eletricidade consumida pelo sistema de concentração deixaria de ser exportada para o Sistema Interligado Nacional (SIN), sendo contabilizada como energia recebida desta rede.

\subsubsection{Cenário 2: Biodigestão anaeróbia com geração de eletricidade}

Neste cenário propõe-se tratar a vinhaça por meio de um biodigestor anaeróbio com produção e captura de biogás para geração de eletricidade. O efluente do biodigestor é utilizado como fertilizante na lavoura, sendo distribuído da mesma forma que no cenário de referência, uma vez que a biodigestão não produz redução do volume do efluente (Figura 26). 
$\mathrm{O}$ biogás obtido é tratado para reduzir a umidade e $\mathrm{o}_{2} \mathrm{~S}$, para ser utilizado como combustível em motogeradores termelétricos de combustão interna. Parte da eletricidade gerada é consumida nas cargas internas do biodigestor e o excedente exportado ao SIN. Foram utilizados tanto dados bibliográficos, como dados primários dos biodigestores da Usina São Martinho e da Usina Ester, assim como dados fornecidos pelos fabricantes de equipamentos.

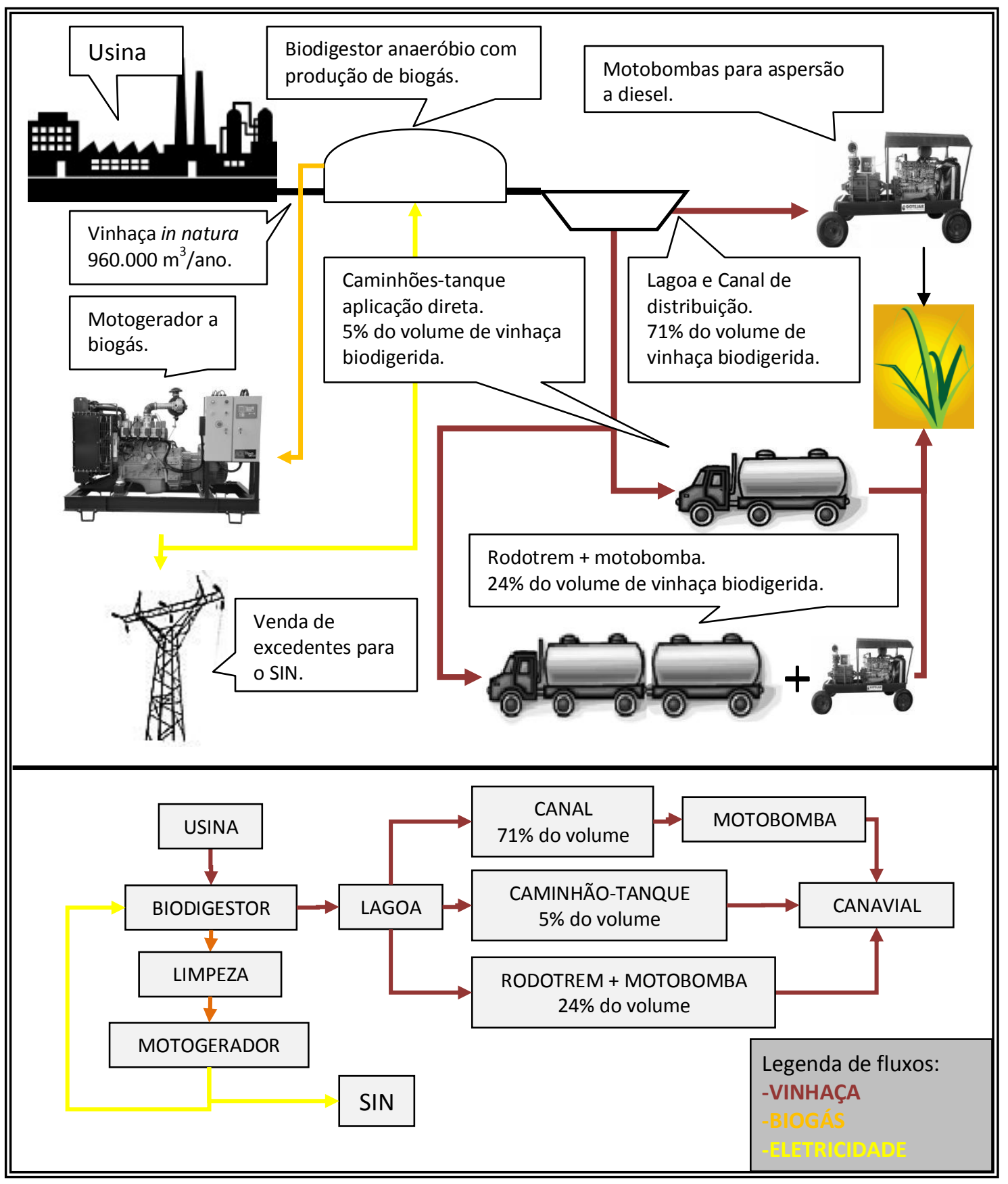

Figura 26. Diagrama explicativo e de fluxos do Cenário 2, Biodigestão anaeróbia com geração de eletricidade. Fonte: Autor. 


\subsubsection{Cenário 3: Incineração com geração de eletricidade}

Neste Cenário 3, primeiramente a vinhaça é concentrada mediante evaporação de múltiplo efeito até atingir $65^{\circ} \mathrm{Bx}$, concentração com a qual a vinhaça adquire suficiente PCI para ser incinerada na caldeira. Para que esta combustão seja completa e estável é necessário utilizar um combustível auxiliar de suporte, assumindo neste caso a utilização de gás natural. O calor desprendido na queima conjunta da vinhaça e do gás natural será utilizado para a geração de vapor e energia elétrica (Figura 27). O consumo térmico do sistema de concentração é suprido parcialmente com o vapor produzido no sistema de cogeração com vinhaça, e deve ser completado com vapor de processo proveniente da usina. A energia elétrica gerada abastece as cargas internas do sistema e o excedente é exportado para o SIN.

Neste caso, o volume de vinhaça é totalmente eliminado, evitando o sistema de transporte e distribuição do mesmo. O único resíduo do processo seriam as cinzas potássicas, utilizadas como fertilizante na lavoura. Os dados sobre a incineração foram obtidos do único fabricante com tecnologia testada para vinhaça, a SAACKE Boiler and Process Firing Systems, com duas plantas no estado do Paraná, Brasil, e outra na Sérvia (SAACKE, 2013).

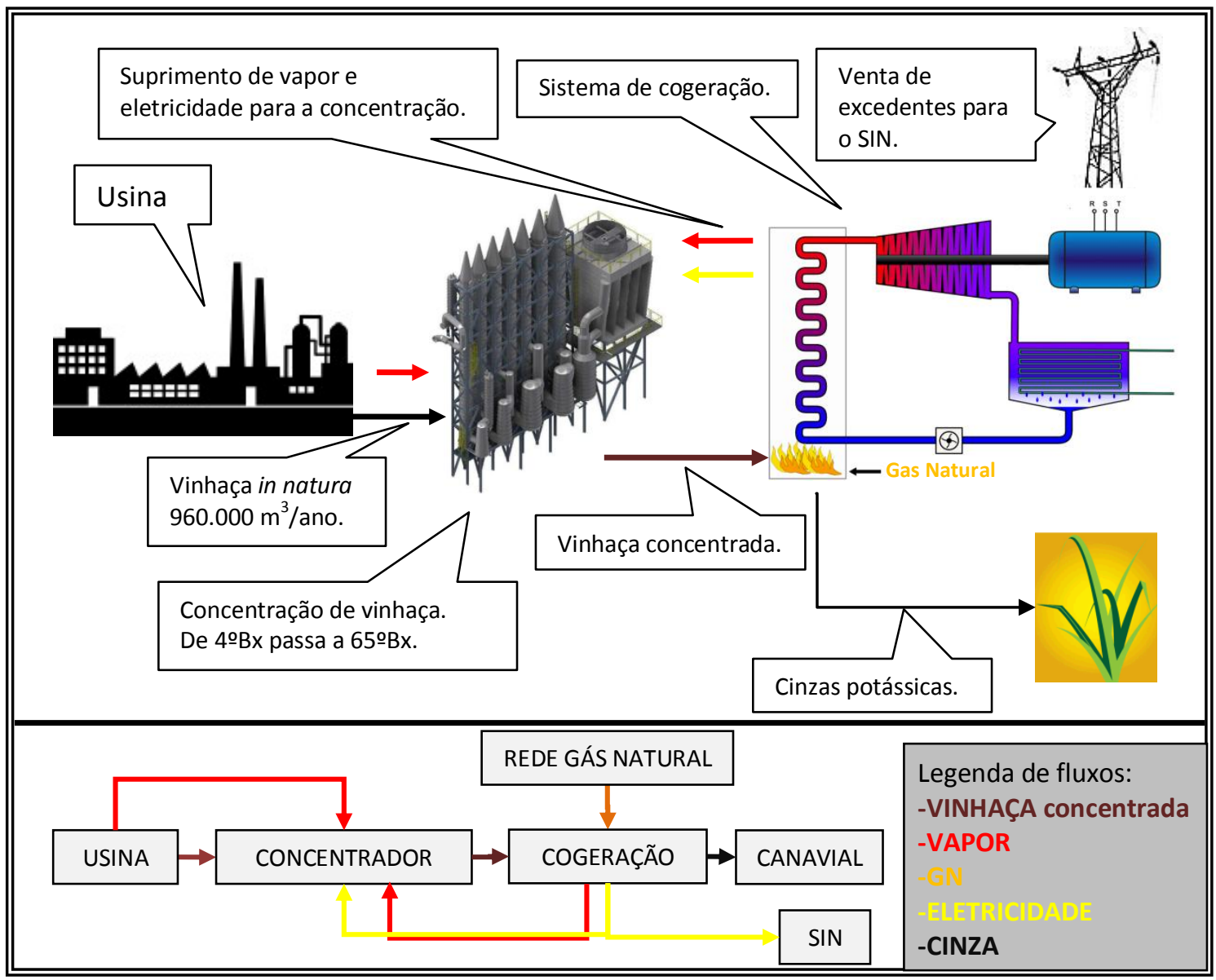

Figura 27. Diagrama explicativo e de fluxos do Cenário 3, Incineração com geração de eletricidade. Fonte: Autor. 


\subsubsection{Cenário 4: Biodigestão com concentração e uso veicular}

Este cenário propõe uma combinação dos Cenários 1 e 2, com a realização da biodigestão para depois concentrar o efluente tratado até alcançar $20^{\circ} \mathrm{Bx}$, distribuindo a vinhaça biodigerida e concentrada no canavial utilizando caminhões-tanque (Figura 28). Além disso, este cenário introduz uma substituição parcial do diesel consumido em todas as operações de campo com o biometano produzido a partir da vinhaça. Existe um exemplo de uso veicular na frota da Usina São João relatado na literatura (BARBERI, 1998). Ainda não existe um exemplo de implantação conjunta destas tecnologias que possa ser estudado como nos casos anteriores, então será utilizada a informação levantada para os Cenários 1 e 2.

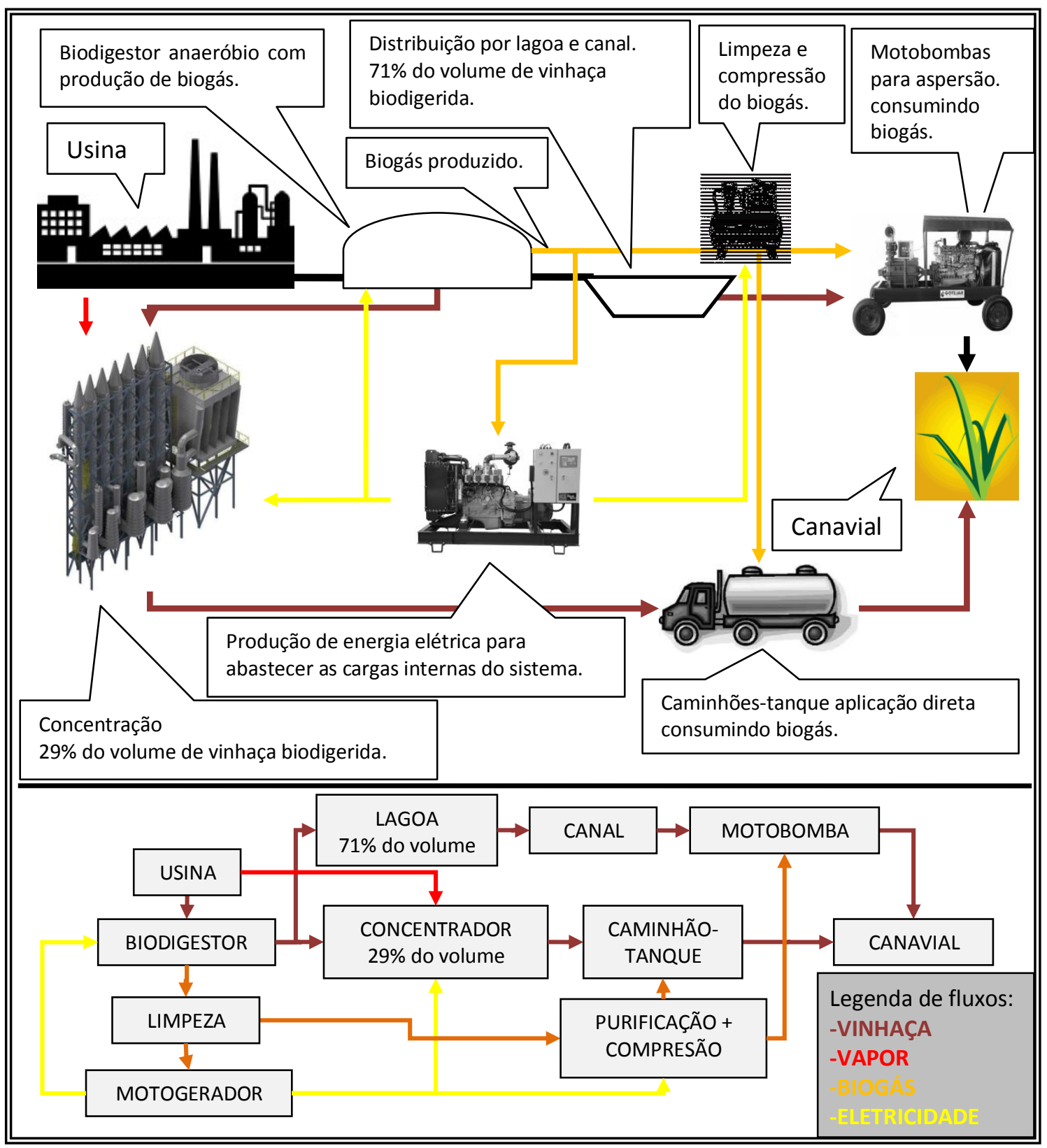

Figura 28. Diagrama explicativo e de fluxos do Cenário 4, Biodigestão com concentração e uso veicular. Fonte: Autor. 
Com a descrição destes cenários, definem-se os elementos que os compõem e estabelecem-se as premissas básicas que serão utilizadas como ponto de partida nos cálculos de balanço energético, e nos capítulos que tratam da avaliação de impacto ambiental e da análise de viabilidade econômica.

Importante ressaltar que estas alternativas não esgotam as possibilidades de processamento e de uso final da vinhaça, mas representam as tecnologias mais desenvolvidas que permitem o aproveitamento energético da mesma.

\subsection{Balanço Energético de cada Cenário}

A seguir, calculam-se os balanços energéticos para cada um dos cinco cenários propostos, isto é, a quantidade de cada tipo de energia consumida e produzida por cada sistema de processamento.

São diferenciados os consumos de energia térmica em forma de vapor de processo, de energia elétrica e de combustíveis fósseis, como o gás natural e o diesel. As premissas básicas foram estabelecidas no capítulo anterior por meio da descrição dos cenários; a seguir são somadas novas considerações que possibilitem a estimativa dos balanços energéticos. Em cada cenário são calculados, quando aplicáveis, os seguintes parâmetros:

a) Consumo e produção de energia elétrica

b) Consumo e produção de energia térmica

c) Consumo de combustível fóssil (diesel ou gás natural)

d) Produção de combustível renovável (biogás).

\subsubsection{Cenário 0 de referência: Fertirrigação com vinhaça in natura.}

Para o cenário de referência é contabilizada a energia consumida no bombeamento, transporte, distribuição e aplicação da vinhaça in natura. O diesel é considerado a única fonte de energia para realizar estas operações unidas à fertirrigação, sabendo que são pouco significativos os casos onde se utilizam motores elétricos para o acionamento de bombas de aspersão. Não foi incluída neste estudo a eletricidade gasta no bombeamento de recalque, necessário para elevar a vinhaça ate os reservatórios desde onde é distribuída por gravidade, por não ter conseguido acesso a este dado. Por tanto, no cenário de referência somente é contabilizado o diesel consumido na fertirrigação. 


\section{Consumo de combustivel na fertirrigação no Cenário 0:}

Para o cálculo do consumo de diesel são assumidos os valores expostos na Tabela 14, onde é definida a porcentagem de vinhaça que é dispersa mediante caminhão com aplicação direta na lavoura, caminhão com aspersão e a sucção desde canal por aspersão, sendo última esta a técnica mais estendida. Nesta tabela, também é indicada a porcentagem de área fertirrigada com cada método, a dosagem de vinhaça em $\mathrm{m}^{3} / \mathrm{ha}$, a distância média que percorrem os caminhões e, por fim, qual é consumo de diesel por $\mathrm{m}^{3}$ de vinhaça e por ha.

Tabela 14. Consumo de combustíveis na maquinaria empregada para fertirrigação.

\begin{tabular}{|c|c|c|c|c|c|c|c|c|}
\hline $\begin{array}{l}\text { Sistema de } \\
\text { transporte e } \\
\text { aplicação }\end{array}$ & Maquinaria & $\begin{array}{c}\% \text { de } \\
\text { volume } \\
\text { vinhaça }\end{array}$ & $\begin{array}{c}\% \text { da área } \\
\text { fertirrigada }\end{array}$ & $\begin{array}{c}\text { Dosagem } \\
\left(\mathbf{m}^{3} / \mathbf{h a}\right)\end{array}$ & $\begin{array}{c}\text { Distancia } \\
\text { media } \\
(\mathbf{k m})\end{array}$ & $\begin{array}{l}\text { Consumo. } \\
\text { diesel }\end{array}$ & $\begin{array}{c}\text { Consumo } \\
\text { diesel por } \\
\mathbf{m}^{3} \text { de } \\
\text { Vinhaça } \\
\left(1 / \mathbf{m}^{3}\right) \\
\end{array}$ & $\begin{array}{c}\text { Consumo } \\
\text { diesel. } \\
\text { (l/ha) } \\
\text { ponderado } \\
\text { por \% área } \\
\end{array}$ \\
\hline $\begin{array}{l}\text { Caminhão } \\
\text { aplicando } \\
\text { diretamente }\end{array}$ & $\begin{array}{l}\text { MB2318 com } \\
\text { tanque de } 15 \mathrm{~m}^{3}\end{array}$ & $5^{b}$ & $6^{a}$ & $100^{\mathrm{a}}$ & $7^{\mathrm{a}}$ & $2,2 \mathrm{~km} / 1^{\mathrm{a}}$ & $0,42^{\mathrm{b}}$ & $2,54^{\mathrm{a}}$ \\
\hline \multirow{2}{*}{$\begin{array}{l}\text { Caminhão com } \\
\text { aspersão } \\
\text { combinado com } \\
\text { motobomba }\end{array}$} & \multirow{2}{*}{$\begin{array}{l}\text { Caminhão } \\
\text { Volvo rodotrem } \\
\text { com dois tanques } \\
\text { de } 30 \mathrm{~m}^{3} / \text { cada e } \\
\text { motobomba. }\end{array}$} & \multirow{2}{*}{$24^{\mathrm{b}}$} & \multirow{2}{*}{$31^{\mathrm{a}}$} & \multirow{2}{*}{$100^{\mathrm{a}}$} & \multirow{2}{*}{$12^{\mathrm{a}}$} & $1,3 \mathrm{~km} / 1^{\mathrm{a}}$ & $0,31^{\mathrm{b}}$ & $9,55^{\mathrm{a}}$ \\
\hline & & & & & & $\begin{array}{c}7,5 \mathrm{~m}^{3} \\
\text { vinhaça/ }{ }^{\mathrm{a}}\end{array}$ & $0,13^{b}$ & $5,30^{\mathrm{b} 28}$ \\
\hline $\begin{array}{l}\text { Motobomba em } \\
\text { canal com } \\
\text { montagem } \\
\text { direta ou com } \\
\text { rolão }\end{array}$ & $\begin{array}{l}\text { Motor } \\
\text { MB-OM352 } \\
160 \mathrm{cv} \\
\text { Bomba } \\
\text { EQ } 90-48 \\
140 \mathrm{~m}^{3} / \mathrm{h}\end{array}$ & $71^{\mathrm{b}}$ & $63^{a}$ & $150^{a}$ & - & $\begin{array}{c}7,5 \mathrm{~m}^{3} \\
\text { vinhaça/l }\end{array}$ & $0,13^{b}$ & $12,60^{\mathrm{a}}$ \\
\hline \multicolumn{4}{|c|}{$\begin{array}{c}\text { Valores médios ponderados por \% } \\
\text { área fertirrigada }\end{array}$} & $131,5^{b}$ & - & - & - & $30,00^{b}$ \\
\hline
\end{tabular}

Fonte: a) Macedo et al. (2004); b) Calculado pelo autor.

Com estes dados, pode-se estimar a superfície de cultivo que é possível fertirrigar com a quantidade de vinhaça produzida. Para calcular a área total fertirrigada são adotados valores médios da produção anual de vinhaça in natura de $4^{\circ}$ Brix (doravante $\mathrm{V}_{4^{\circ} \mathrm{Bx}}{ }^{29}$ ) e da dose de vinhaça por hectare (Equação 1).

Para estimar qual seria a porcentagem do cultivo de cana que é fertirrigado, calcula-se a área coletada necessária correspondente à produção anual de etanol, tendo em conta a produção média de cana por hectare no Estado de São Paulo e a produtividade de etanol hidratado por tonelada de cana processada (Equação 2).

$$
\begin{gathered}
S_{F}=\frac{V_{4^{\circ} \mathrm{Bx} / \text { ano }}}{D_{4^{\circ} \mathrm{Bx}}} \\
S_{\mathrm{P}}=\frac{\mathrm{V}_{\mathrm{E} / \mathrm{ano}}}{\mathrm{V}_{\mathrm{E} / \mathrm{ha}}}
\end{gathered}
$$

Equação 1

Equação 2

\footnotetext{
${ }^{28}$ Macedo et al. (2004) consideraram unicamente o consumo de diesel do transporte em rodotrem, excluindo o consumo da motobomba (Macedo et al. (2004), Anexo 1, pag. 24, Memória de cálculo). No presente trabalho se inclui este consumo.

${ }^{29}$ Para fazer referência à Vinhaça de $\mathrm{X}^{\circ}$ Brix a nomenclatura adotada neste trabalho é $\mathrm{V}_{\mathrm{XBx}^{\circ}}$
} 
Onde:

\begin{tabular}{|c|c|c|c|}
\hline \multicolumn{4}{|c|}{ Dados de entrada } \\
\hline Símbolo & Significado & Valor & Fonte \\
\hline $\mathrm{D}_{4^{\circ} \mathrm{Bx}}$ & Dosagem média de fertirrigação com vinhaça $4^{\circ} \mathrm{Bx}$ & $131,5 \mathrm{~m}^{3} / \mathrm{ha}$ & Tabela 14 \\
\hline $\mathrm{V}_{4^{\circ} \mathrm{Bx} / \mathrm{ano}}$ & Volume de vinhaça $4^{\circ} \mathrm{Bx}$ produzido por ano & $960.000 \mathrm{~m}^{3} /$ ano & Tabela 2 \\
\hline $\mathrm{v}_{\mathrm{E} / \mathrm{ha}}$ & Volume de etanol produzido por ha & $6,7 \mathrm{~m}^{3} / \mathrm{ha}$ & Tabela 2 \\
\hline $\mathrm{V}_{\mathrm{E} / \mathrm{ano}}$ & Volume de etanol produzido por ano & $88.248 \mathrm{~m}^{3} /$ ano & Tabela 2 \\
\hline \multicolumn{4}{|c|}{ Resultados } \\
\hline $\mathrm{S}_{\mathrm{F}}$ & Superfície fertirrigada & $7.281 \mathrm{ha} / \mathrm{ano}$ & Equação 1 \\
\hline $\mathrm{S}_{\mathrm{P}}$ & Superfície coletada & 13.200 ha/ano & Equação 2 \\
\hline
\end{tabular}

Pode-se observar que, nas condições propostas, poderia ser fertirrigada mais da metade da área destinada à produção de etanol.

Com os valores obtidos, estima-se o consumo médio de diesel para distribuir $1 \mathrm{~m}^{3} \mathrm{da}$ vinhaça para fertirrigação (Equação 3). Multiplicando este consumo unitário pelo volume anual de vinhaça, obtém-se o consumo total de diesel neste cenário (Equação 4). Sabendo o PCI deste combustível, é calculada a energia térmica equivalente (Equação 5).

$$
\begin{array}{cc}
\mathrm{c}_{\text {diesel } / \mathrm{V} 4^{\circ} \mathrm{Bx}}=\frac{\mathrm{c}_{\text {diesel } / \mathrm{ha}}}{\mathrm{D}_{4^{\circ} \mathrm{Bx}}} & \text { Equação 3 } \\
\mathrm{C}_{\text {diesel } / \text { ano }}=\mathrm{c}_{\text {diesel } / \mathrm{V} 4^{\circ} \mathrm{Bx}} \times \mathrm{V}_{4^{\circ} \mathrm{Bx} / \text { ano }} & \text { Equação } 4 \\
\mathrm{Q}_{\text {diesel } / \text { ano }}=\mathrm{C}_{\text {diesel } / \text { ano }} \times \mathrm{PCI}_{\text {diesel }} & \text { Equação } 5
\end{array}
$$

\begin{tabular}{|c|c|c|c|}
\hline \multicolumn{4}{|c|}{ Dados de entrada } \\
\hline Símbolo & Significado & Valor & Fonte \\
\hline $\mathrm{D}_{4^{\circ} \mathrm{Bx}}$ & Dosagem media de fertirrigação com vinhaça $4^{\circ} \mathrm{Bx}$ & $131,5 \mathrm{~m}^{3} / \mathrm{ha}$ & Tabela 14 \\
\hline $\mathrm{V}_{4^{\circ} \mathrm{B} \times / \text { ano }}$ & Volume de vinhaça $4^{\circ} \mathrm{Bx}$ produzido por ano & $960.000 \mathrm{~m}^{3} / \mathrm{ano}$ & Tabela 2 \\
\hline $\mathrm{PCI}_{\text {diesel }}$ & Poder Calorífico Inferior do diesel & $36.031 \mathrm{~kJ} / \mathrm{l}$ & ANP, 2014 \\
\hline $\mathrm{c}_{\text {diesel/ha }}$ & Consumo de diesel por ha fertirrigada & $30 \mathrm{l} / \mathrm{ha}$ & Tabela 14 \\
\hline \multicolumn{4}{|c|}{ Resultados } \\
\hline $\mathrm{C}_{\text {diesel } / \mathrm{V} 4^{\circ} \mathrm{Bx}}$ & Consumo de diesel por $\mathrm{m}^{3}$ de vinhaça $4^{\circ} \mathrm{Bx}$ por ano & $0,228 \mathrm{~L} / \mathrm{m}^{3}$ & Equação 3 \\
\hline $\mathrm{C}_{\text {diesel/ano }}$ & Consumo de diesel anual & $219 \mathrm{~m}^{3} / \mathrm{ano}$ & Equação 4 \\
\hline $\mathrm{Q}_{\text {diesel/ano }}$ & Energia consumida proveniente de diesel por ano & $7,9 \mathrm{TJ} / \mathrm{ano}$ & Equação 5 \\
\hline
\end{tabular}

Onde:

Observa-se a significativa quantidade de diesel empregada na distribuição da vinhaça (219 $\left.\mathrm{m}^{3} / \mathrm{ano}\right)$. Este consumo energético do cenário de referência será comparado com o correspondente dos demais cenários.

\subsubsection{Cenário 1: Concentração evaporativa}

Nesta seção, calcula-se a energia consumida na concentração, considerando a energia térmica e elétrica necessária para a evaporação e, posteriormente, o consumo de combustível 
empregado nos equipamentos que distribuem o volume de vinhaça concentrada e in natura. Com esta finalidade, deve ser dimensionada a capacidade de evaporação necessária de um concentrador no caso estudado (Equação 6).

$$
\begin{array}{cr}
\mathrm{M}_{\text {evap } / \text { ano }}=\mathrm{V}_{\% \text { conc }} \times \mathrm{V}_{4^{\circ} \mathrm{Bx} / \text { ano }} \times \mathrm{m}_{\mathrm{evap} / \mathrm{V} 4^{\circ} \mathrm{Bx}} & \text { Equação } 6 \\
\mathrm{C}_{\text {evap }}=\frac{\mathrm{M}_{\text {evap } / \text { ano }}}{\mathrm{T}_{\mathrm{s}}} & \text { Equação } 7
\end{array}
$$

\begin{tabular}{|c|c|c|c|}
\hline \multicolumn{4}{|c|}{ Dados de entrada } \\
\hline Símbolo & Significado & Valor & Fonte \\
\hline $\mathrm{V}_{4^{\circ} \mathrm{B} \mathrm{B} / \mathrm{ano}}$ & Volume de vinhaça $4^{\circ} \mathrm{Bx}$ produzido por ano & $960.000 \mathrm{~m}^{3} / \mathrm{ano}$ & Tabela 2 \\
\hline $\mathrm{m}_{\text {evap } / \mathrm{V} 4^{\circ} \mathrm{Bx}}$ & Água evaporada por $\mathrm{m}^{3}$ de $\mathrm{V}_{4^{\circ} \mathrm{Bx}}$ concentrada até $\mathrm{V}_{20^{\circ} \mathrm{Bx}}$ & $811,2 \mathrm{~kg} / \mathrm{m}^{3}$ & Tabela 15 \\
\hline $\mathrm{V}_{\% \text { conc }}$ & Porcentagem de volume concentrado & $29 \%$ & Tabela 14 \\
\hline $\mathrm{T}_{\mathrm{s}}$ & Tempo de safra & $5.808 \mathrm{~h} / \mathrm{ano}$ & Tabela 2 \\
\hline \multicolumn{4}{|c|}{ Resultados } \\
\hline$M_{\text {evap/ano }}$ & Água evaporada por ano & $225.838 \mathrm{t} / \mathrm{ano}$ & Equação 6 \\
\hline $\mathrm{C}_{\text {evap }}$ & Capacidade do evaporador & $40 \mathrm{t} / \mathrm{h}$ & Equação 7 \\
\hline
\end{tabular}

Onde:

Como resultado obtém-se que, para a usina de porte médio proposta e a porcentagem de vinhaça destinada à concentração, seria necessário instalar, no mínimo, um concentrador com 40 t/h de capacidade de evaporação. Este evaporador pode ser considerado de baixa capacidade, pois no mercado existem concentradores de $250 \mathrm{t} / \mathrm{h}$ de capacidade de evaporação, não existindo uma limitação técnica neste aspecto para o cenário configurado.

\section{Consumo de energia elétrica na concentração no Cenário 1:}

Segundo os fornecedores de equipamentos, a potência instalada nos motores de um evaporador de $250 \mathrm{t} / \mathrm{h}$ de capacidade de evaporação seria de $800 \mathrm{~kW}_{\mathrm{e}}$ com demanda de $80 \%$, podendo-se assumir como consumo específico de eletricidade na concentração o valor de 2,6 $\mathrm{kWh}_{\mathrm{e}}$ por tonelada de evaporação. Neste caso o evaporador utilizado no Cenário 1 é de $40 \mathrm{t} / \mathrm{h}$ (Equação 7) de modo que a potência instalada proporcional deveria ser de $128 \mathrm{~kW}_{\mathrm{e}}$, tendo um consumo elétrico de $600 \mathrm{MWh}_{\mathrm{e}} / \mathrm{ano}$. Como foi indicado anteriormente, é considerado que a eletricidade consumida pelo sistema de concentração deixaria de ser exportada para o SIN porque seria proveniente dos excedentes produzidos pelo sistema de cogeração da usina, podendo ser contabilizada como energia retirada desta rede.

Consumo de energia térmica na concentração no Cenário 1:

Este fabricante de equipamentos Citrotec SL possui três modelos de evaporadores de múltiplo efeito. $\mathrm{O}$ modelo mais antigo é o Ecovin ${ }^{\circledR}$, um evaporador de 5 a 7 efeitos que 
utiliza vapor de processo de 1,5 bar (Tabela 7). A segunda opção é o EcovinJL®, que está acoplado às colunas de destilação, evitando o consumo adicional de vapor. Por último, a terceira opção é o Ecowaste® (ainda em fase de testes) que utiliza como fonte energética os gases de exaustão das caldeiras de bagaço e que permite, segundo o fabricante, a concentração sem consumo adicional de vapor. Neste estudo é utilizado o consumo de energia para um evaporador Ecovin® de 7 efeitos, cujo consumo é de $1 \mathrm{~kg}$ de vapor por 6,2 $\mathrm{kg}$ de evaporação, assumindo uma porcentagem de sólidos iniciais da $\mathrm{V}_{4^{\circ} \mathrm{Bx}}$. A Tabela 15 ilustra a evolução das características da solução, a quantidade de água a evaporar e o consumo de vapor necessário por cada $\mathrm{m}^{3}$ de $\mathrm{V}_{4^{\circ} \mathrm{Bx}}$, conforme a concentração final é incrementada. Os valores desta tabela foram calculados com base na concentração de soluto mostrada na Tabela 3, a densidade indicada na Tabela 6 e o consumo de vapor que aparece na Tabela 7.

Tabela 15. Quantidade de água a evaporar por $\mathbf{m}^{3}$ de $\mathrm{V}_{4^{\circ} \mathrm{Bx}}$ para atingir diferentes graus de concentração.

\begin{tabular}{|c|c|c|c|c|c|c|}
\hline $\begin{array}{c}\text { Concentração } \\
\left({ }^{\circ} \mathbf{B x}\right)\end{array}$ & $\begin{array}{c}\text { Massa de } \\
\text { Soluto } \\
\left(\mathrm{kg} / \mathrm{m}^{3} \text { de } V_{4^{\circ} \mathrm{Bx}}\right) \\
\end{array}$ & $\begin{array}{c}\text { Massa de } \\
\text { Água } \\
\left(\mathrm{kg} / \mathrm{m}^{3} \text { de } \mathbf{V}^{\circ} \mathrm{Bx}\right) \\
\end{array}$ & $\begin{array}{c}\text { Massa Total } \\
\left(\mathrm{kg} / \mathrm{m}^{3} \text { de } \mathbf{V}_{4^{\circ} \mathrm{Bx}}\right)\end{array}$ & $\begin{array}{c}\text { Densidade } \\
\left(\mathrm{kg} / \mathrm{m}^{3}\right)\end{array}$ & $\begin{array}{c}\text { Água } \\
\text { Evaporada } \\
\left(\mathrm{kg} / \mathrm{m}^{3} \text { de } \mathrm{V}_{\mathbf{4}^{\circ} \mathrm{Bx}}\right) \\
\end{array}$ & $\begin{array}{c}\text { Consumo de vapor } \\
\text { Ecovin } \\
\left(\mathrm{kg} / \mathrm{m}^{3} \text { de } \mathbf{V 4}^{\circ} \mathbf{B x}\right) \\
\end{array}$ \\
\hline 4 & 40,56 & 973,4 & 1014,0 & 1,01 & 0 & 0 \\
\hline 10 & 40,56 & 365,0 & 405,6 & 1,04 & 608,4 & 98,1 \\
\hline 20 & 40,56 & 162,2 & 202,8 & 1,07 & 811,2 & 130,8 \\
\hline 30 & 40,56 & 94,6 & 135,2 & 1,12 & 878,8 & 141,7 \\
\hline 40 & 40,56 & 60,8 & 101,4 & 1,16 & 912,6 & 147,2 \\
\hline 50 & 40,56 & 40,6 & 81,1 & 1,21 & 932,9 & 150,5 \\
\hline 60 & 40,56 & 27,0 & 67,6 & 1,26 & 946,4 & 152,6 \\
\hline 65 & 40,56 & 21,8 & 62,4 & 1,29 & 951,6 & 153,5 \\
\hline
\end{tabular}

Fonte: Cálculos do autor baseados nos dados da CETESB (1982), GEA (2007) e CITROTEC® (2013).

Neste Cenário 1 se estabelece que seja concentrada a fração do volume de vinhaça que precisa ser transportado em caminhão ( $29 \%$ do volume total de $\mathrm{V} 4^{\circ} \mathrm{Bx}$ ) até uma concentração final desejada de $20^{\circ} \mathrm{Bx}$, podendo ser estimado o consumo de vapor de processo (Equação 8).

Onde:

$$
\mathrm{M}_{\mathrm{vap} / \mathrm{ano}}=\mathrm{V}_{\% \text { conc }} \times \mathrm{V}_{4^{\circ} \mathrm{Bx} / \mathrm{ano}} \times \mathrm{m}_{\mathrm{vap} / \mathrm{V} 4^{\circ} \mathrm{Bx}} \quad \text { Equação } 8
$$

\begin{tabular}{llll}
\hline Símbolo & Significado & Dados de entrada & Falor \\
$\mathrm{V}_{4^{\circ} \mathrm{Bx} / \mathrm{ano}}$ & Volume de vinhaça $4^{\circ} \mathrm{Bx}$ produzido por ano & $960.000 \mathrm{~m}^{3} / \mathrm{ano}$ & Tabela 2 \\
$\mathrm{~m}_{\mathrm{vap} / \mathrm{V} 4^{\circ} \mathrm{Bx}}$ & Vapor consumido por $\mathrm{m}^{3}$ de $\mathrm{V}_{4^{\circ} \mathrm{Bx}}$ concentrada até $\mathrm{V}_{20^{\circ} \mathrm{Bx}}$ & $130,8 \mathrm{~kg} / \mathrm{m}^{3}$ & Tabela 15 \\
$\mathrm{~V}_{\% \text { conc }}$ & Porcentagem de volume concentrado & $29 \%$ & Tabela 14 \\
$\mathrm{M}_{\mathrm{vap} / \mathrm{ano}}$ & Resultados & & \\
\hline
\end{tabular}

Uma vez conhecida a quantidade de vapor necessária para realizar a concentração, calcula-se a energia e o combustível consumido para produzi-lo. Como foi definido 
anteriormente, este suprimento de vapor vem da usina que possui um sistema de cogeração (Figura 29).

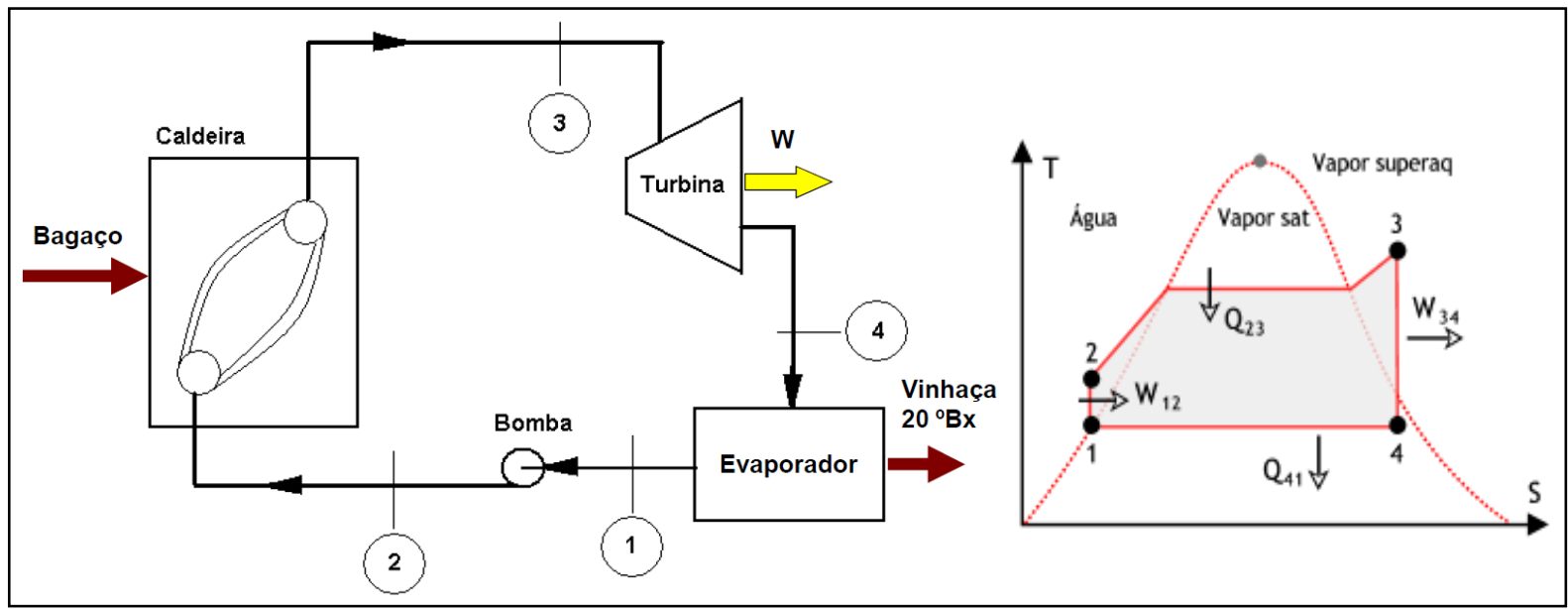

Figura 29. Representação do sistema de cogeração e diagrama termodinâmico ideal T-S do ciclo que supre o evaporador no Cenário 1. Fonte: Autor.

Este sistema funciona com uma caldeira de 42 bar de pressão manométrica, $400{ }^{\circ} \mathrm{C}$ e $\eta_{c}=0,8$ (rendimento da caldeira). O vapor é expandindo em uma turbina com $\eta_{\mathrm{t}}=0,8$ (rendimento da turbina isentrópico). O vapor de processo deve ser tratado como um insumo, mas a energia elétrica gerada (W) por este sistema de cogeração não é inserida como produto no balanço energético deste cenário, pois não é decorrente do tratamento da vinhaça.

O calor que deve ser fornecido pelo combustível na caldeira vem determinado pela quantidade de vapor consumida no evaporador e sua entalpia de entrada e de saída. Observase que o evaporador funciona como condensador deste ciclo Rankine. Na Tabela 16 se resumem os parâmetros termodinâmicos que caracterizam os pontos do ciclo, considerando-se que a pressão manométrica do vapor do processo é 1,5 bar.

Tabela 16. Parâmetros termodinâmicos do ciclo de cogeração do Cenário 1.

\begin{tabular}{|c|c|c|c|c|c|c|c|c|c|}
\hline Ponto & Tabela & $\begin{array}{l}\text { Pressão } \\
\text { (MPa) }\end{array}$ & $\begin{array}{c}\text { Temper. } \\
\left({ }^{\circ} \mathrm{C}\right)\end{array}$ & $\begin{array}{c}\text { Entalpia } \\
\text { especifica } \\
\text { "h" } \\
(\mathrm{kJ} / \mathrm{kg})\end{array}$ & $\begin{array}{c}\text { Entropia } \\
\text { especifica } \\
\text { "s" } \\
(\mathrm{kJ} / \mathrm{kg} \mathrm{K})\end{array}$ & $\begin{array}{c}S_{L} \\
(\mathrm{~kJ} / \mathrm{kg} \mathrm{K})\end{array}$ & $\begin{array}{c}S_{V} \\
(\mathrm{~kJ} / \mathrm{kg} \mathrm{K})\end{array}$ & $\begin{array}{c}\mathbf{h}_{\mathbf{L}} \\
(\mathbf{k J} / \mathbf{k g})\end{array}$ & $\begin{array}{c}\mathbf{h}_{\mathbf{V}} \\
(\mathrm{kJ} / \mathrm{kg})\end{array}$ \\
\hline 1 & água saturada & $0,25^{\mathrm{a}}$ & $126,8^{b}$ & $535,34^{b}$ & - & $1,6072^{b}$ & - & $535,34^{b}$ & - \\
\hline 2 & água saturada & - & $126,8^{b}$ & $535,34^{b}$ & - & - & - & - & - \\
\hline 3 & vapor superaquecido & $4,3^{\mathrm{a}}$ & $400^{\mathrm{a}}$ & $3209,1^{b}$ & $6,7319^{b}$ & - & - & - & - \\
\hline 4 & vapor saturado & $0,25^{\mathrm{a}}$ & $126,8^{b}$ & $2712,56^{*}$ & $6,7319^{b}$ & - & $7,0526^{\mathrm{b}}$ & - & $2716,9^{b}$ \\
\hline
\end{tabular}

Fonte:

a) Valor preestabelecido no cenário.

b) Valor tabelado obtido em http://www.steamtablesonline.com/ (acessado em 2014)

c) Valor calculado (Equação 11)

Com os valores da Tabela 16, é calculado o título isentrópico do vapor na entrada do evaporador (Equação 9), assim como a entalpia isentrópica (Equação 10) e a real (Equação 
11). O calor a ser fornecido pela caldeira vem definido pela Equação 12. Considerando o rendimento da caldeira, o calor a ser fornecido pelo combustível é calculado na Equação 13. Esta energia térmica necessária se traduz no consumo anual de bagaço calculado na Equação 14.

$$
\begin{aligned}
& \mathrm{X}_{4 \text { iso }}=\frac{\mathrm{S}_{4}-\mathrm{S}_{\mathrm{L}}}{\mathrm{S}_{\mathrm{V}}-\mathrm{S}_{\mathrm{L}}} \\
& \mathrm{h}_{4 \text { iso }}=\mathrm{X}_{4 \text { iso }} \times \mathrm{h}_{\mathrm{V}}+\left(1-\mathrm{X}_{4}\right) \times \mathrm{h}_{\mathrm{L}} \\
& \text { Equação } 10 \\
& \mathrm{~h}_{4}=\eta_{\mathrm{t}} \times\left(\mathrm{h}_{4 \text { iso }}-\mathrm{h}_{3}\right)+\mathrm{h}_{3} \\
& \text { Equação } 11 \\
& \mathrm{Q}_{\mathrm{c} / \mathrm{ano}}=\mathrm{M}_{\mathrm{vap} / \mathrm{ano}} \times\left(\mathrm{h}_{4}-\mathrm{h}_{1}\right) \\
& \mathrm{Q}_{\text {comb/ano }}=\frac{\mathrm{Q}_{\mathrm{c} / \mathrm{ano}}}{\eta_{\mathrm{c}}} \\
& \mathrm{M}_{\text {bagaço/ano }}=\frac{\mathrm{Q}_{\text {comb/ano }}}{\mathrm{PCI}_{\text {bagaço }}}
\end{aligned}
$$

\begin{tabular}{|c|c|c|c|}
\hline \multicolumn{4}{|c|}{ Dados de entrada } \\
\hline Símbolo & Significado & Valor & Fonte \\
\hline $\mathrm{h}_{4 \text { iso }}$ & Entalpia específica isotrópica do vapor no ponto 4 & $2588,42 \mathrm{~kJ} / \mathrm{kg}$ & Tabela 2 \\
\hline $\mathrm{h}_{\mathrm{L}}$ & Entalpia específica da água saturada & $535,34 \mathrm{~kJ} / \mathrm{kg}$ & Tabela 16 \\
\hline$h_{V}$ & Entalpia específica do vapor saturado & $2716,9 \mathrm{~kJ} / \mathrm{kg}$ & Tabela 16 \\
\hline $\mathrm{h}_{\mathrm{x}}$ & Entalpia específica do vapor no ponto $\mathrm{x}$ & $x=1,3$ e 4 & Tabela 16 \\
\hline $\mathrm{M}_{\mathrm{vap} / \mathrm{ano}}$ & Vapor consumido por ano no evaporador & $36,3 \times 10^{6} \mathrm{~kg} / \mathrm{ano}$ & Equação 8 \\
\hline $\mathrm{PCI}_{\text {bagaço }}$ & Poder calorífico do bagaço com $50 \%$ de umidade & $9,6 \mathrm{~kJ} / \mathrm{kg}$ & \\
\hline $\mathrm{S}_{4}$ & Entropia específica do vapor no ponto 4 & $6,7319 \mathrm{~kJ} / \mathrm{kg} \mathrm{K}$ & Tabela 16 \\
\hline $\mathrm{S}_{\mathrm{L}}$ & Entropia específica da água saturada ${ }^{*}$ & $1,6072 \mathrm{~kJ} / \mathrm{kg} \mathrm{K}$ & Tabela 16 \\
\hline $\mathrm{S}_{\mathrm{V}}$ & Entropia específica do vapor saturado & $7,0526 \mathrm{~kJ} / \mathrm{kg} \mathrm{K}$ & Tabela 16 \\
\hline$\eta_{\mathrm{c}}$ & Rendimento da caldeira & 0,8 & \\
\hline$\eta_{t}$ & Rendimento da turbina & 0,8 & \\
\hline \multicolumn{4}{|c|}{ Resultados } \\
\hline $\mathrm{X}_{4 \text { iso }}$ & Título isentrópico do vapor no ponto 4 & 0,94 & Equação 9 \\
\hline $\mathrm{Q}_{\mathrm{c} / \mathrm{ano}}$ & Calor a ser fornecido pela caldeira por ano & $72 \mathrm{TJ}$ & Equação 12 \\
\hline $\mathrm{Q}_{\text {comb./ano }}$ & Calor a ser fornecido pelo combustível por ano & $90,2 \mathrm{TJ}$ & Equação 13 \\
\hline $\mathrm{M}_{\text {bagaço/ano }}$ & Bagaço consumido pela caldeira por ano & $9,4 \times 10^{3} \mathrm{t}$ & Equação 14 \\
\hline
\end{tabular}

Onde:

${ }^{*} \mathrm{~T}=126,8^{\circ} \mathrm{C} ; \mathrm{P}=0,25 \mathrm{MPa}$

Por último, o fabricante indica que com os sistemas EcovinJL® e Ecowaste ${ }^{\circledR}$, este consumo poderia ser considerado praticamente nulo, não existindo necessidade adicional de vapor de processo por aproveitar o calor residual da usina. 


\section{Consumo de combustível no transporte no Cenário 1:}

Para o cálculo do consumo de diesel na distribuição da vinhaça concentrada, considerase que deve ser mantida a mesma dosagem de sólidos por ha que no cenário de referência. Utilizando os valores calculados na Tabela 15, pode-se calcular que uma dose de $100 \mathrm{~m} / \mathrm{ha}$ com $\mathrm{V}_{4^{\circ} \mathrm{Bx}}$ seria equivalente a $19 \mathrm{~m}^{3} /$ ha com $\mathrm{V}_{20^{\circ} \mathrm{Bx}}$ depois da concentração (Equação 15).

$$
\mathrm{d}_{\mathrm{V} 20^{\circ} \mathrm{Bx}}=\frac{[\mathrm{S}]_{\mathrm{V}^{4} \mathrm{Bx}}}{[\mathrm{S}]_{\mathrm{V} 20^{\circ} \mathrm{Bx}}} \times \mathrm{d}_{\mathrm{V} 4^{\circ} \mathrm{Bx}} \quad \text { Equação } 15
$$

Onde:

\begin{tabular}{|c|c|c|c|}
\hline \multicolumn{4}{|c|}{ Dados de entrada } \\
\hline Símbolo & Significado & Valor & Fonte \\
\hline$[\mathrm{S}]_{\mathrm{V} 4^{\circ} \mathrm{Bx}}$ & Concentração de soluto em $\mathrm{V}_{4^{\circ} \mathrm{Bx}}$ & $40 \mathrm{~kg} / \mathrm{m}^{3}$ & Tabela 15 \\
\hline$[\mathrm{S}]_{\mathrm{V} 20^{\circ} \mathrm{Bx}}$ & Concentração de soluto em $\mathrm{V}_{20^{\circ} \mathrm{Bx}}$ & $215 \mathrm{~kg} / \mathrm{m}^{3}$ & Tabela 15 \\
\hline $\mathrm{d}_{\mathrm{V} 4^{\circ} \mathrm{Bx}}$ & Dosagem de $\mathrm{V}_{4^{\circ} \mathrm{Bx}}$ por ha & $100 \mathrm{~m}^{3} / \mathrm{ha}$ & Tabela 14 \\
\hline \multicolumn{4}{|c|}{ Resultados } \\
\hline $\mathrm{d}_{\mathrm{V} 20^{\circ} \mathrm{Bx}}$ & Dosagem de $\mathrm{V}_{20^{\circ} \mathrm{Bx}}$ por ha & $19 \mathrm{~m}^{3} / \mathrm{ha}$ & Equação 15 \\
\hline
\end{tabular}

Por outro lado, com o aumento da viscosidade provocado pela concentração (GEA WIEGAND GMBH, 2007), os sistemas baseados na aspersão são inviabilizados, devendo ser substituída a aspersão que utiliza o rodo-trem e a motobomba pela aplicação direta da vinhaça. Isto implica em um aumento na distância media e em variações no consumo de diesel, sendo mostrados os resultados dos cálculos na Tabela 17.

Tabela 17. Consumo de diesel na fertirrigação com vinhaça concentrada e in natura.

\begin{tabular}{|c|c|c|c|c|c|c|c|c|}
\hline $\begin{array}{l}\text { Sistema de } \\
\text { transporte e } \\
\text { aplicação }\end{array}$ & Maquinaria & $\begin{array}{c}\% \text { de } \\
\text { vinhaça }\end{array}$ & $\begin{array}{c}\% \text { da área } \\
\text { fertirrigada }\end{array}$ & $\begin{array}{c}\text { Dosagem } \\
\left(\mathbf{m}^{3} / \mathbf{h a}\right)\end{array}$ & $\begin{array}{l}\text { Distan. } \\
\text { media } \\
(\mathbf{k m})\end{array}$ & $\begin{array}{l}\text { Consumo } \\
\text { unitário } \\
\text { de diesel }\end{array}$ & $\begin{array}{c}\text { Consumo diesel } \\
\text { por } \mathbf{m}^{3} \text { de } \\
\text { Vinhaça } \\
\left(1 / \mathbf{m}^{3}\right)\end{array}$ & $\begin{array}{c}\text { Consumo } \\
\text { diesel } \\
\text { ponderado } \\
\text { (l/ha) }\end{array}$ \\
\hline $\begin{array}{l}\text { Caminhão } \\
\text { aplicando } \\
\text { diretamente } \\
\text { concentrada }\end{array}$ & $\begin{array}{l}\text { MB2318 com } \\
\text { tanque de } 15 \mathrm{~m}^{3}\end{array}$ & $29 \%$ & $37 \%$ & $\begin{array}{c}19 \\
\left(\mathrm{~V}_{20^{\circ} \mathrm{Bx}}\right)\end{array}$ & 11,19 & $2,20 \mathrm{~km} / 1$ & 0,13 & 4,74 \\
\hline $\begin{array}{l}\text { Sistema de } \\
\text { aspersão } \\
\text { aplicando } \\
\text { in natura }\end{array}$ & $\begin{array}{l}\text { Motobomba em } \\
\text { canal com } \\
\text { montagem } \\
\text { direta ou rolão }\end{array}$ & $71 \%$ & $63 \%$ & $\begin{array}{c}150 \\
\left(\mathrm{~V}_{4^{\circ} \mathrm{Bx}}\right)\end{array}$ & - & $\begin{array}{c}7,5 \mathrm{~m}^{3} \\
\text { vinhaça/1 }\end{array}$ & 0,13 & 12,6 \\
\hline TOTAL & & $100 \%$ & $100 \%$ & $\begin{array}{l}131,5 \\
\left(V_{4^{\circ} \mathrm{Bx}}\right)\end{array}$ & - & - & - & 17,34 \\
\hline
\end{tabular}

Fonte: Calculado pelo autor baseado em dados de Macedo et al. (2004).

Estima-se que o consumo médio de diesel para a fertirrigação neste cenário seja de 17,34 1/ha, o que significaria um montante de $126 \mathrm{~m}^{3}$ de diesel por ano (Equação 16).

$$
\begin{array}{cc}
\mathrm{C}_{\text {diesel/ano }}=\mathrm{c}_{\text {diesel } / \text { ha }} \times \mathrm{S}_{\mathrm{F}} & \text { Equação } 16 \\
\mathrm{Q}_{\text {diesel } / \text { ano }}=\mathrm{C}_{\text {diesel/ano }} \times \mathrm{PCI}_{\text {diesel }} & \text { Equação } 17
\end{array}
$$


Onde:

\begin{tabular}{|c|c|c|c|}
\hline \multicolumn{4}{|c|}{ Dados de entrada } \\
\hline Símbolo & Significado & Valor & Fonte \\
\hline $\mathrm{PCI}_{\text {diesel }}$ & Poder Calorífico Inferior do diesel & $36.031 \mathrm{~kJ} / \mathrm{L}$ & \\
\hline $\mathrm{c}_{\text {diesel/ha }}$ & Consumo de diesel por ha fertirrigada & $17,34 \mathrm{~L} / \mathrm{ha}$ & Tabela 17 \\
\hline $\mathrm{S}_{\mathrm{F}}$ & Superfície fertirrigada & $7.281 \mathrm{ha} / \mathrm{ano}$ & Equação 1 \\
\hline \multicolumn{4}{|c|}{ Resultados } \\
\hline $\mathrm{C}_{\text {diesel/ano }}$ & Consumo de diesel anual & $126 \mathrm{~m}^{3} /$ ano & Equação 16 \\
\hline $\mathrm{Q}_{\text {diesel/ano }}$ & Energia consumida proveniente de diesel por ano & $4,5 \mathrm{TJ} / \mathrm{ano}$ & Equação 17 \\
\hline
\end{tabular}

Dessa forma, pode-se concluir que o consumo de diesel de 219 mªno no cenário de referência se reduziria a $126 \mathrm{~m}^{3}$, o que significa 43\% de redução do consumo de diesel com a concentração de $29 \%$ do volume de vinhaça e mantendo a mesma dosagem de nutrientes.

\subsubsection{Cenário 2: Biodigestão anaeróbia com geração de eletricidade}

Neste caso, o balanço energético incorpora o consumo do sistema de biodigestão e da fertirrigação. Por outro lado, há uma produção de biogás que é utilizado para alimentar motogeradores e produzir energia elétrica, suprindo as cargas internas do biodigestor e exportando o excedente no SIN.

Consumo de eletricidade na biodigestão e dessulfurização no Cenário 2:

Segundo o fabricante de reatores IC, para tratar $4.200 \mathrm{~m}^{3}$ de vinhaça por dia com uma carga de DQO $40 \mathrm{~kg} / \mathrm{m}^{3}$ seria necessário instalar $150 \mathrm{~kW}$ em cargas internas. Por outro lado, a potência elétrica instalada de um biodigestor UASB para tratar $5.000 \mathrm{~m} 3 /$ dia e de um sistema de dessulfurização do biogás somam 250 kW (SALOMON, 2007). Baseado nestes dados, assume-se uma potência elétrica instalada de $200 \mathrm{~kW}_{\text {e }}$ para um biodigestor de $4.000 \mathrm{~m}^{3}$ /dia incluindo o dessulfurizador. A energia consumida em todo o período da safra é calculada na Equação 18.

$$
\mathrm{C}_{\text {e.biod/ano }}=\mathrm{P}_{\text {e.biod. }} \times \mathrm{T}_{\mathrm{s}} \quad \text { Equação } 18
$$

Onde:

\begin{tabular}{llll}
\hline Símbolo & Significado & \multicolumn{1}{c}{ Dados de entrada } & \\
$\mathrm{P}_{\text {e.biod }}$ & Potência elétrica instalada no biodigestor & Valor & Fonte \\
$\mathrm{T}_{\mathrm{s}}$ & \multicolumn{1}{c}{ Duração da safra } & $200 \mathrm{~kW}_{\mathrm{e}}$ & \\
& & $5.808 \mathrm{~h} / \mathrm{ano}$ & Tabela 2 \\
& & & \\
$\mathrm{C}_{\text {e.biod./ano }}$ & Consumo anual de eletricidade na biodigestão & $1,2 \mathrm{GWh}_{\mathrm{e}} / \mathrm{ano}$ & Equação 18 \\
\hline
\end{tabular}

Essa energia consumida pelas cargas internas do processo é incluída no balanço energético, sendo subtraída da energia gerada pelo motogerador a biogás. 
Consumo de combustível no transporte no Cenário 2:

Como a biodigestão não altera de forma significativa o volume de vinhaça, o consumo na fertirrigação seria muito próximo ao calculado no cenário de referência, que foi estimado em $219 \mathrm{~m}^{3}$ de diesel por ano.

Produção de biogás e energia elétrica no Cenário 2:

Para calcular a produção de biogás foram levantados dados dos biodigestores das usinas Ester e São Martinho, bem como os fornecidos pelos fabricantes e os encontrados na bibliografia. Na Tabela 18 são resumidos os resultados deste levantamento, onde se apresentam dados sobre o tipo de reator empregado, os parâmetros que definem sua dimensão e operação, capacidade de tratamento de DQO, produtividade e eficiência na conversão da matéria orgânica em biogás, e finalmente a porcentagem de metano contida no mesmo.

Tabela 18. Biogás produzido com vinhaça.

\begin{tabular}{|c|c|c|c|c|c|c|c|c|}
\hline Referência & $\begin{array}{l}\text { Tipo de } \\
\text { reator }\end{array}$ & $\begin{array}{c}\mathrm{kg} \\
\mathrm{DQO} / \mathrm{m}^{3} \\
\text { vinhaça }\end{array}$ & $\begin{array}{c}\text { Taxa de } \\
\text { carregamento } \\
\text { orgânico } \\
\left(\mathrm{kg} \mathrm{DQO} / \mathrm{m}^{3} \mathrm{de}\right. \\
\text { reator.dia) }\end{array}$ & $\begin{array}{l}\text { Tempo de } \\
\text { Retenção } \\
\text { Hidráulica } \\
\text { (h) }\end{array}$ & $\begin{array}{c}\text { Taxa de } \\
\text { remoção } \\
\text { DQO } \\
(\%)\end{array}$ & $\begin{array}{c}\text { Produção de } \\
\text { gás } \\
\left(\mathrm{m}^{3} \text { de gás/ }\right. \\
\text { kg de DQO } \\
\text { alimentada) }\end{array}$ & $\begin{array}{c}\mathrm{Nm}^{3} \text { de } \\
\text { biogás/m } \\
\text { de } \\
\text { vinhaça }\end{array}$ & $\begin{array}{l}\mathrm{CH}_{4} \\
(\%)\end{array}$ \\
\hline SOUZA (1992) & $\begin{array}{l}\text { UASB } \\
\left(75 \mathrm{~m}^{3}\right)\end{array}$ & 31,8 & 26,5 & 10,8 & 72 & 0,37 & 11,8 & 60 \\
\hline $\begin{array}{l}\text { Destilaria Central } \\
\text { Jacques Richer } \\
\text { CAMPOS (1981) }\end{array}$ & $\begin{array}{l}\text { UASB } \\
\left(330 \mathrm{~m}^{3}\right)\end{array}$ & - & - & 10 & 62 & - & 16,5 & 55 \\
\hline $\begin{array}{l}\text { Usina São João. } \\
\text { PINTO (1999) }\end{array}$ & $\begin{array}{c}\text { UASB } \\
\left(1.000 \mathrm{~m}^{3}\right)\end{array}$ & - & - & - & 85 & - & $\begin{array}{c}\text { Média de } \\
4,3 \\
(\operatorname{Max} 7,2)\end{array}$ & 60 \\
\hline $\begin{array}{c}\text { Usina Ester, Omnis } \\
\text { Biotechnology } \\
(2013)\end{array}$ & $\begin{array}{c}\text { Lagoa } \\
\left(15.000 \mathrm{~m}^{3}\right)\end{array}$ & $20-60$ & 2,0 & 288,0 & 95 & 0,20 & $4,0-12,0$ & - \\
\hline $\begin{array}{c}\text { Usina São } \\
\text { Martinho (2013) }\end{array}$ & $\begin{array}{c}\text { UASB } \\
\left(5.000 \mathrm{~m}^{3}\right)\end{array}$ & $20-30$ & 6,0 & 100,0 & 70 & 0,24 & 6,0 & 50 \\
\hline $\begin{array}{c}\text { Fabricante de IC } \\
\text { (2014) }\end{array}$ & $\begin{array}{c}\text { IC } \\
\left(2.520 \mathrm{~m}^{3}\right)\end{array}$ & $20-25$ & 22,2 & 24,3 & 65 & 0,29 & 6,4 & $60-65$ \\
\hline
\end{tabular}

Fonte: Autor.

As características do biogás produzido na usina São Martinho são mostradas na Tabela 19, sendo estes valores muito conservadores. Em vista da grande variabilidade nos valores obtidos, foram escolhidos primeiramente para o cálculo os dados provenientes da usina São Martinho, por ser um projeto com porte industrial e longo tempo de funcionamento, além de constituir um dado primário.

Tabela 19. Parâmetros da Planta de Biodigestão de São Martinho.

\begin{tabular}{lc}
\hline \multicolumn{1}{c}{ Parâmetro } & Valor \\
\hline Vazão de vinhaça & $50 \mathrm{~m}^{3} / \mathrm{h}^{\mathrm{a}}$ \\
DQO & $25 \mathrm{~g} / \mathrm{l}^{\mathrm{a}}$ \\
Produção de biogás diária de biogás & $300 \mathrm{Nm}^{3} / \mathrm{h}^{\mathrm{a}}$ \\
\hline
\end{tabular}




\begin{tabular}{lc}
\hline \multicolumn{2}{c}{ Composição e características do biogás } \\
\hline $\mathrm{CH}_{4}$ & $50 \%{ }^{\mathrm{a}}$ \\
$\mathrm{CO}_{2}$ & $50 \%^{\mathrm{a}}$ \\
$\mathrm{H}_{2} \mathrm{~S}$ & $<1 \%{ }^{\mathrm{a}}$ \\
$\mathrm{PCI}$ do $\mathrm{CH}_{4}$ & $35.530 \mathrm{~kJ} / \mathrm{Nm}^{3 \mathrm{~b}}$ \\
$\mathrm{PCI}$ do biogás & $17.765 \mathrm{~kJ} / \mathrm{Nm}^{3 \mathrm{c}}$ \\
\hline
\end{tabular}

\section{Fontes:}

a) São Martinho, 2013. b) Salomon, 2007. c) Calculada: 50\% do PCI do $\mathrm{CH}_{4}$

Com estes dados, obtém-se a produção anual de $\mathrm{CH}_{4}$ (Equação 19). Supondo uma perda de biogás por vazamento de $5 \%$ no sistema de biodigestão, e considerando a geração de energia elétrica por meio de um motor de combustão interna de eficiência termelétrica de $29 \%$, pode ser calculada a energia térmica e elétrica disponível por safra proveniente do biogás (Equação 20 e Equação 21), assim como a potência de geração elétrica que deveria ser instalada (Equação 22).

$$
\begin{gathered}
\mathrm{V}_{\text {biogás } / \text { ano }}=\mathrm{V}_{\text {biogás } / \mathrm{V} 4^{\circ} \mathrm{Bx}} \times \mathrm{V}_{4^{\circ} \mathrm{Bx} / \text { ano }} \\
\mathrm{Q}_{\text {biogás/ano }}=\mathrm{V}_{\text {biogás/ano }} \times\left(1-\mathrm{V}_{\mathrm{ovaz}}\right) \times \mathrm{PCI}_{\text {biogás }} \\
\mathrm{E}_{\mathrm{e} / \text { ano }}=\left(\mathrm{Q}_{\text {biogás/ano }} \times \eta_{\mathrm{e} / \mathrm{t}}\right)-\mathrm{C}_{\text {e.biod/ano }} \\
\mathrm{P}_{\mathrm{g}}=\frac{\mathrm{Q}_{\text {biogás/ano }} \times \eta_{\mathrm{e} / \mathrm{t}}}{\mathrm{T}_{\mathrm{s}}}
\end{gathered}
$$

Equação 19

Equação 20

\begin{tabular}{|c|c|c|c|}
\hline \multicolumn{4}{|c|}{ Dados de entrada } \\
\hline Símbolo & Significado & Valor & Fonte \\
\hline $\mathrm{C}_{\text {e.biod./ano }}$ & Consumo anual de eletricidade na biodigestão & $1.162 \mathrm{MWh}_{\mathrm{e}}$ & Equação 18 \\
\hline $\mathrm{T}_{\mathrm{s}}$ & Duração da safra & $5.808 \mathrm{~h}$ & Tabela 2 \\
\hline $\mathrm{V}_{4^{\circ} \mathrm{Bx} / \mathrm{ano}}$ & Volume de vinhaça $4^{\circ} \mathrm{Bx}$ produzido por ano & $960.000 \mathrm{~m}^{3} /$ ano & Tabela 2 \\
\hline $\mathrm{V}_{\% \mathrm{vaz}}$ & Porcentagem de volume de biogás vazado & $5 \%$ & \\
\hline $\mathrm{V}_{\text {biogás} / \mathrm{V} 4^{\circ} \mathrm{Bx}}$ & Volume de biogás produzido por cada $\mathrm{m}^{3}$ de vinhaça & $6 \mathrm{Nm}^{3} / \mathrm{m}^{3}$ & Tabela 18 \\
\hline $\mathrm{PCI}_{\text {biogás }}$ & Poder Calorífico Inferior do biogás & $17.765 \mathrm{~kJ} / \mathrm{Nm}^{3}$ & Tabela 19 \\
\hline$\eta_{\mathrm{e} / \mathrm{t}}$ & Rendimento de termoelétrico do motor & 0,29 & \\
\hline \multicolumn{4}{|c|}{ Resultados } \\
\hline $\mathrm{V}_{\text {biogás/ano }}$ & Volume de biogás produzido por ano & $5.745 .000 \mathrm{Nm}^{3} /$ ano & Equação 19 \\
\hline Q biogás/ano & Energia térmica produzida com biogás por ano & $97 \mathrm{TJ} / \mathrm{ano}$ & Equação 20 \\
\hline $\mathrm{E}_{\mathrm{e} / \mathrm{ano}}$ & Energia elétrica exportada por ano & $6,6 \mathrm{GWh}_{\mathrm{e}} / \mathrm{ano}$ & Equação 21 \\
\hline $\mathrm{P}_{\mathrm{g}}$ & Potência elétrica de geração instalada & $1,3 \mathrm{MW}_{\mathrm{e}}$ & Equação 22 \\
\hline
\end{tabular}

Equação 21

Equação 22

Onde:

A energia produzida pelos geradores seria de aproximadamente 7,8 $\mathrm{GWh}_{\mathrm{e}} / \mathrm{ano}$, do que deve ser subtraído o consumido nas cargas internas do biodigestor e sistema de 
dessulfurização. Em definitivo, tem-se um balanço positivo de geração de energia elétrica de 6,6 GWhe/ano (Equação 21) que pode ser exportada para o SIN.

\subsubsection{Cenário 3: Incineração com geração de eletricidade}

Para efetuar o balanço energético da incineração, deve ser calculado por um lado, o consumo de energia do sistema de concentração que leva a vinhaça a uma condição favorável para sua queima, e por outro, a energia produzida nesta queima.

Será considerado o consumo de gás natural como combustível suporte que é misturado e incinerado junto a vinhaça concentrada mediante um queimador torsional. Esta combustão se produz dentro de uma caldeira de 42 bar de pressão manométrica, $400{ }^{\circ} \mathrm{C}$ e $\eta_{\mathrm{c}}=0,8$. O vapor passará por uma turbina de contrapressão de fluxo direto com $\eta_{t}=0,6$ acoplada a um gerador de $\eta_{\mathrm{g}}=0,9 . \mathrm{O}$ vapor extraído da turbina e a eletricidade gerada no sistema de concentração de vinhaça são utilizados para fornecer a demanda de energia do sistema de concentração.

A incineração elimina totalmente o volume de vinhaça, deixando unicamente como resíduo sólido as cinzas potássicas que seriam distribuídas como fertilizante. O consumo energético provocado por esta distribuição não é incluído no balanço energético deste cenário, por ser realizado junto à sulcação ${ }^{30}$ e adubação, sendo esta uma prática cultural realizada independentemente do tratamento da vinhaça.

Consumo de energia elétrica do sistema de concentração no Cenário 3:

Para calcular a energia elétrica consumida pelo concentrador é estimada a capacidade que deveria ter este equipamento (Equação 24).

$$
\begin{gathered}
\mathrm{M}_{\text {evap } / \mathrm{ano}}=\mathrm{V}_{4^{\circ} \mathrm{Bx} / \mathrm{ano}} \times \mathrm{m}_{\text {evap } / \mathrm{V} 4^{\circ} \mathrm{Bx}} \\
\mathrm{C}_{\text {evap }}=\frac{\mathrm{M}_{\text {evap } / \mathrm{ano}}}{\mathrm{T}_{\mathrm{s}}}
\end{gathered}
$$

Equação 24

\begin{tabular}{|c|c|c|c|}
\hline \multicolumn{4}{|c|}{ Dados de entrada } \\
\hline Símbolo & Significado & Valor & Fonte \\
\hline $\mathrm{V}_{4^{\circ} \mathrm{Bx} / \mathrm{ano}}$ & Volume de vinhaça $4^{\circ} \mathrm{Bx}$ produzido por ano & $960.000 \mathrm{~m}^{3} / \mathrm{ano}$ & Tabela 2 \\
\hline $\mathrm{m}_{\text {evap } / \mathrm{V} 4^{\circ} \mathrm{Bx}}$ & Água evaporada por $\mathrm{m}^{3}$ de $\mathrm{V}_{4^{\circ} \mathrm{Bx}}$ concentrada até $\mathrm{V}_{65^{\circ} \mathrm{Bx}}$ & $951,6 \mathrm{~kg} / \mathrm{m}^{3}$ & Tabela 15 \\
\hline $\mathrm{T}_{\mathrm{s}}$ & Tempo de safra & $5.808 \mathrm{~h} / \mathrm{ano}$ & Tabela 2 \\
\hline \multicolumn{4}{|c|}{ Resultados } \\
\hline$M_{\text {evap/ano }}$ & Água evaporada por ano & $911 \times 10^{3}$ t/ano & Equação 23 \\
\hline $\mathrm{C}_{\text {evap }}$ & Capacidade do evaporador & $160 \mathrm{t} / \mathrm{h}$ & Equação 24 \\
\hline
\end{tabular}

Onde:

\footnotetext{
${ }^{30}$ Fazer sulcos para realizar o plantio da cultura.
} 
Considerando o consumo específico de eletricidade na concentração igual a 2,6 kWh por tonelada de evaporação, estima-se que esta instalação consome 2,3 $\mathrm{GWh}_{\mathrm{e}} /$ ano.

\section{Consumo de energia térmica do sistema de concentração no Cenário 3:}

A seguir, calcula-se a quantidade de vapor de processo necessária a um concentrador para levar vinhaça in natura de $4^{\circ} \mathrm{Bx}$ até uma concentração final de $65^{\circ} \mathrm{Bx}$ (Equação 25).

$$
\mathrm{M}_{\mathrm{vap} / \mathrm{ano}}=\mathrm{V}_{4^{\circ} \mathrm{Bx} / \mathrm{ano}} \times \mathrm{m}_{\mathrm{vap} / \mathrm{V} 4^{\circ} \mathrm{Bx}} \quad \text { Equação } 25
$$

Onde:

\begin{tabular}{|c|c|c|c|}
\hline \multicolumn{4}{|c|}{ Dados de entrada } \\
\hline Símbolo & Significado & Valor & Fonte \\
\hline $\mathrm{m}_{\mathrm{vap} / \mathrm{V} 4^{\circ} \mathrm{Bx}}$ & Vapor consumido por $\mathrm{m}^{3}$ de $\mathrm{V}_{4^{\circ} \mathrm{Bx}}$ concentrada até $\mathrm{V}_{65^{\circ} \mathrm{Bx}}$ & $153,5 \mathrm{~kg} / \mathrm{m}^{3}$ & Tabela 15 \\
\hline $\mathrm{V}_{4^{\circ} \mathrm{Bx} / \mathrm{ano}}$ & Volume de vinhaça $4^{\circ} \mathrm{Bx}$ produzido por ano & $960.000 \mathrm{~m}^{3} / \mathrm{ano}$ & Tabela 2 \\
\hline \multicolumn{4}{|c|}{ Resultados } \\
\hline $\mathrm{M}_{\text {vap/ano }}$ & Vapor consumido pelo evaporador por ano & $147 \times 10^{6} \mathrm{~kg} / \mathrm{ano}$ & Equação 25 \\
\hline
\end{tabular}

O vapor de processo vem do sistema de cogeração representado na Figura 30. O vapor é gerado em uma caldeira alimentada com vinhaça e gás natural, posteriormente expandido em uma turbina e finalmente condensado no evaporador que concentra a vinhaça.

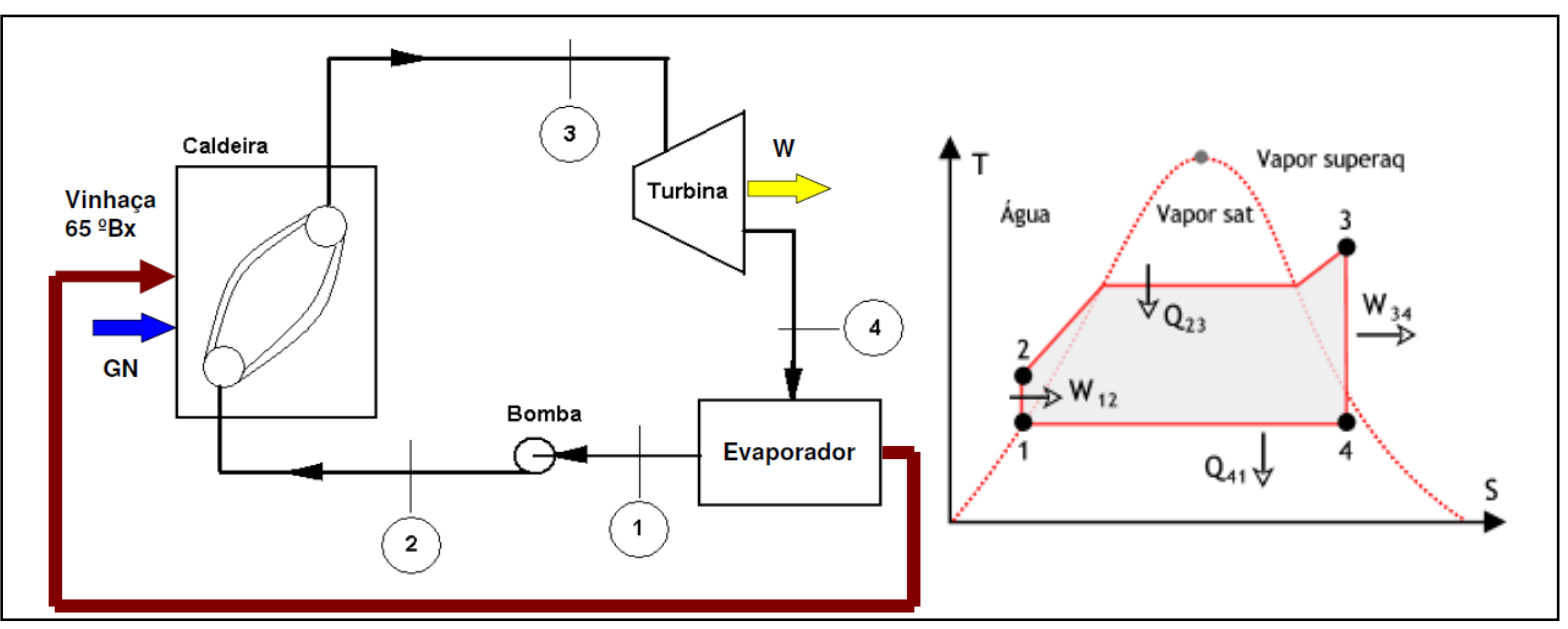

Figura 30. Representação do sistema de cogeração e diagrama termodinâmico ideal T-S do ciclo que supre o evaporador no Cenário 4. Fonte: Autor.

Os parâmetros termodinâmicos que caracterizam os pontos do ciclo representado são iguais aos que aparecem na Tabela 16, visto que as pressões de entrada e de saída da turbina são idênticas. $\mathrm{O}$ único parâmetro que varia é $\mathrm{h}_{4}$ devido ao rendimento da turbina ser de 0,6 , por se tratar de um sistema de pequeno porte e de menor rendimento. Com os valores termodinâmicos da Tabela 16, calcula-se a entalpia real de saída da turbina. O calor a ser fornecido pela caldeira vem definido pela Equação 27, e o calor a ser fornecido pelo 
combustível (mistura de vinhaça concentrada e gás natural) é calculado considerando o rendimento da caldeira (Equação 28).

$$
\begin{array}{cc}
\mathrm{h}_{4}=\eta_{\mathrm{t}} \times\left(\mathrm{h}_{4 \text { iso }}-\mathrm{h}_{3}\right)+\mathrm{h}_{3} & \text { Equação 26 } \\
\mathrm{Q}_{\mathrm{c} / \mathrm{ano}}=\mathrm{M}_{\mathrm{vap} / \mathrm{ano}} \times\left(\mathrm{h}_{4}-\mathrm{h}_{1}\right) & \text { Equação 27 } \\
\mathrm{Q}_{\mathrm{comb} / \mathrm{ano}}=\frac{\mathrm{Q}_{\mathrm{c} / \mathrm{ano}}}{\eta_{\mathrm{c}}} & \text { Equação 28 }
\end{array}
$$

\begin{tabular}{|c|c|c|c|}
\hline \multicolumn{4}{|c|}{ Dados de entrada } \\
\hline Símbolo & Significado & Valor & Fonte \\
\hline $\mathrm{h}_{4 \text { iso }}$ & Entalpia específica isotrópica do vapor no ponto 4 & $2588,42 \mathrm{~kJ} / \mathrm{kg}$ & Tabela 16 \\
\hline$h_{x}$, & Entalpia específica do vapor no ponto $\mathrm{x}$ & $x=1$ e 3 & Tabela 16 \\
\hline $\mathrm{M}_{\mathrm{vap} / \text { ano }}$ & Vapor consumido por ano no evaporador & $147 \times 10^{6} \mathrm{~kg} / \mathrm{ano}$ & Equação 25 \\
\hline$\eta_{\mathrm{c}}$ & Rendimento da caldeira & 0,8 & \\
\hline$\eta_{\mathrm{t}}$ & Rendimento da turbina & 0,6 & \\
\hline \multicolumn{4}{|c|}{ Resultados } \\
\hline $\mathrm{h}_{4}$ & Entalpia específica do vapor no ponto 4 & $2.836,7 \mathrm{~kJ} / \mathrm{kg}$ & Equação 26 \\
\hline $\mathrm{Q}_{\mathrm{c} / \mathrm{ano}}$ & Calor a ser fornecido pela caldeira por ano & $393 \mathrm{TJ} / \mathrm{ano}$ & Equação 27 \\
\hline $\mathrm{Q}_{\text {comb./ano }}$ & Calor a ser fornecido pelo combustível por ano & $491 \mathrm{TJ} / \mathrm{ano}$ & Equação 28 \\
\hline
\end{tabular}

Onde:

Como resultado, obtém-se que o calor a ser fornecido pelo combustível para concentrar todo o volume de vinhaça até $65^{\circ} \mathrm{Bx}$ é $491 \mathrm{TJ} / \mathrm{ano}$. A seguir, busca-se verificar se a incineração da vinhaça junto ao gás natural proporciona completamente esta demanda térmica ou se pelo contrário, o balanço energético é negativo.

\section{Produção de energia térmica na incineração no Cenário 3:}

Nesta secção, calcula-se o volume de vinhaça que será necessário incinerar (Equação 29) conhecendo a massa de $\mathrm{V}_{65^{\circ} \mathrm{Bx}}$ que pode ser obtida de cada $\mathrm{m}^{3}$ de $\mathrm{V}_{4^{\circ} \mathrm{Bx}}$ (Tabela 15). Com este valor e o PCI da $\mathrm{V}_{65^{\circ} \mathrm{Bx}}$, calcula-se a energia térmica gerada com sua queima (Equação 30). Sendo conhecida a proporção de gás e de vinhaça concentrada que deve ser introduzida na caldeira para assegurar sua combustão, pode-se estimar a quantidade de gás natural necessária anualmente (Equação 31) e a energia liberada na sua queima (Equação 32). Finalmente, obtem-se o calor desprendido através da queima conjunta destes combustíveis (Equação 33)

$$
\begin{gathered}
\mathrm{M}_{65^{\circ} \mathrm{Bx} / \mathrm{ano}}=\mathrm{V}_{4^{\circ} \mathrm{Bx} / \mathrm{ano}} \times \mathrm{m}_{65^{\circ} \mathrm{Bx} / \mathrm{V} 4^{\circ} \mathrm{Bx}} \\
\mathrm{Q}_{65^{\circ} \mathrm{Bx} / \mathrm{ano}}=\mathrm{M}_{65^{\circ} \mathrm{Bx} / \mathrm{ano}} \times \mathrm{PCI}_{65^{\circ} \mathrm{Bx}} \\
\mathrm{V}_{\mathrm{GN} / \mathrm{ano}}=\mathrm{M}_{65^{\circ} \mathrm{Bx} / \mathrm{ano}} \times \mathrm{V}_{\mathrm{GN} / \mathrm{kg} 65^{\circ} \mathrm{Bx}}
\end{gathered}
$$

Equação 29

Equação 30

Equação 31 


$$
\begin{gathered}
\mathrm{Q}_{\mathrm{GN} / \mathrm{ano}}=\mathrm{V}_{\mathrm{GN} / \mathrm{ano}} \times \mathrm{PCI}_{\mathrm{GN}} \\
\mathrm{Q}_{\text {total } / \mathrm{ano}}=\mathrm{Q}_{65^{\circ} \mathrm{Bx} / \mathrm{ano}}+\mathrm{Q}_{\mathrm{GN} / \mathrm{ano}} \sim \mathrm{Q}_{\mathrm{comb} / \mathrm{ano}} \\
\mathrm{P}_{\mathrm{t}}=\mathrm{Q}_{\text {total } / \mathrm{ano}} / \mathrm{T}_{\mathrm{s}}
\end{gathered}
$$

\begin{tabular}{|c|c|c|c|}
\hline \multicolumn{4}{|c|}{ Dados de entrada } \\
\hline Símbolo & Significado & Valor & Fonte \\
\hline $\mathrm{V}_{4^{\circ} \mathrm{B} x / \mathrm{ano}}$ & Volume de vinhaça $4^{\circ} \mathrm{Bx}$ produzido por ano & $960.000 \mathrm{~m}^{3}$ & Tabela 2 \\
\hline $\mathrm{m}_{65^{\circ} \mathrm{Bx} / \mathrm{V} 4^{\circ} \mathrm{Bx}}$ & Massa de vinhaça com $65^{\circ} \mathrm{Bx}$ por $\mathrm{m}^{3}$ de vinhaça $4^{\circ} \mathrm{Bx}$ & $62,4 \mathrm{~kg} / \mathrm{m}^{3}$ & Tabela 15 \\
\hline $\mathrm{PCI}_{65^{\circ} \mathrm{Bx}}$ & Poder Calorífico Inferior da vinhaça com $65^{\circ} \mathrm{Bx}$ & $7.167 \mathrm{~kJ} / \mathrm{kg}$ & $\begin{array}{l}\text { AVRAM et al., } \\
2006\end{array}$ \\
\hline $\mathrm{PCI}_{\mathrm{GN}}$ & Poder Calorífico Inferior do gás natural & $35.530 \mathrm{~kJ} / \mathrm{Nm}^{3}$ & Tabela 19 \\
\hline $\mathrm{V}_{\mathrm{GN} / \mathrm{kg} 65^{\circ} \mathrm{Bx}}$ & Volume de GN por cada $\mathrm{kg}$ de vinhaça com $65^{\circ} \mathrm{Bx}$ & $0,02 \mathrm{Nm}^{3} / \mathrm{kg}$ & SAACKE, 2013 \\
\hline $\mathrm{Q}_{\text {comb./ano }}$ & Calor a ser fornecido pelo combustível por ano & 491 TJ/ano & Equação 28 \\
\hline $\mathrm{T}_{\mathrm{s}}$ & Tempo de safra & $5.808 \mathrm{~h} / \mathrm{ano}$ & Tabela 2 \\
\hline \multicolumn{4}{|c|}{ Resultados } \\
\hline $\mathrm{M}_{65^{\circ} \mathrm{Bx} / \mathrm{ano}}$ & Massa de vinhaça com $65^{\circ} \mathrm{Bx}$ por ano & 60.000 t/ano & Equação 29 \\
\hline $\mathrm{V}_{\mathrm{GN} / \text { ano }}$ & Volume de gás natural consumido por ano & $1,2 \times 10^{6} \mathrm{Nm}^{3}$ & Equação 30 \\
\hline $\mathrm{Q}_{65^{\circ} \mathrm{Bx} / \mathrm{ano}}$ & Energia térmica produzida com vinhaça $65^{\circ} \mathrm{Bx}$ por ano & $429 \mathrm{TJ} / \mathrm{ano}$ & Equação 31 \\
\hline $\mathrm{Q}_{\mathrm{GN} / \text { ano }}$ & Energia térmica produzida com gás natural por ano & $42 \mathrm{TJ} / \mathrm{ano}$ & Equação 32 \\
\hline $\mathrm{Q}_{\text {total/ano }}$ & Energia térmica produzida com vinhaça e gás natural & $471 \mathrm{TJ} / \mathrm{ano}$ & Equação 33 \\
\hline $\mathrm{P}_{\mathrm{t}}$ & Potencia térmica instalada & $22,5 \mathrm{MW}_{\mathrm{t}}$ & Equação 34 \\
\hline
\end{tabular}

Onde:

Somando a energia da queima da vinhaça com a do gás natural, obtém-se 470 TJ/ano, potência muito próxima à demandada para a concentração de 491 TJ/ano (Equação 33). Deve-se ter em conta que existem tecnologias de aproveitamento de calor residual (Ex: EcovinJL® e Ecowaste $\left.{ }^{\circledR}\right)$, o que reduz significativamente o consumo de vapor, dispensando a necessidade do fornecimento adicional de vapor por parte da caldeira da usina ou de gás natural.

\section{Energia elétrica gerada no Cenário 3:}

Para estimar o potencial de produção de energia elétrica a partir da incineração, assumese que o vapor gerado na caldeira é expandido em uma turbina até a pressão de processo, sendo posteriormente utilizado no evaporador (Figura 30). Para o cálculo da potência fornecida pela turbina aplica-se a Equação 36. Aplicando o rendimento do gerador, calcula-se a energia elétrica produzida por ano (Equação 37) e também a potência instalada (Equação $38)$.

$$
\begin{array}{cc}
\mathrm{M}_{\mathrm{vap} / \mathrm{ano}}=\mathrm{M}_{\mathrm{t} / \text { ano }} & \text { Equação } 35 \\
-\mathrm{W}_{\mathrm{t} / \text { ano }}=\mathrm{M}_{\mathrm{t} / \text { ano }} \mathrm{x}\left(\mathrm{h}_{4}-\mathrm{h}_{3}\right) & \text { Equação } 36
\end{array}
$$




$$
\begin{array}{cc}
\mathrm{E}_{\mathrm{e} / \mathrm{ano}}=\left(\mathrm{W}_{\mathrm{t} / \mathrm{ano}} \times \eta_{\mathrm{g}}\right)-\mathrm{C}_{\text {e.conc./ano }} & \text { Equação } 37 \\
\mathrm{P}_{\mathrm{g}}=\frac{\mathrm{W}_{\mathrm{t} / \text { ano }} \times \eta_{\mathrm{g}}}{\mathrm{T}_{\mathrm{s}}} & \text { Equação } 38
\end{array}
$$

\begin{tabular}{|c|c|c|c|}
\hline \multicolumn{4}{|c|}{ Dados de entrada } \\
\hline Símbolo & Significado & Valor & Fonte \\
\hline $\mathrm{m}_{\mathrm{vap} / \mathrm{ano}}$ & Vapor consumido pelo evaporador por ano & $147 \times 10^{6} \mathrm{~kg} / \mathrm{ano}$ & Equação 25 \\
\hline $\mathrm{T}_{\mathrm{s}}$ & Duração da safra & $5.808 \mathrm{~h} / \mathrm{ano}$ & Tabela 2 \\
\hline $\mathrm{h}_{\mathrm{x}}$ & Entalpia específica do vapor no ponto $\mathrm{x}$ & $x=3$ e 4 & Tabela 16 \\
\hline$\eta_{\mathrm{g}}$ & Rendimento do gerador & 0,9 & \\
\hline $\mathrm{C}_{\text {e.conc./ano }}$ & Consumo anual de eletricidade na concentração & 2,3 $\mathrm{GWh}_{\mathrm{e}} / \mathrm{ano}$ & \\
\hline \multicolumn{4}{|c|}{ Resultados } \\
\hline $\mathrm{m}_{\mathrm{t} / \text { ano }}$ & Vapor consumido pela turbina por ano & $147 \times 10^{6} \mathrm{~kg} / \mathrm{ano}$ & Equação 35 \\
\hline $\mathrm{W}_{\mathrm{t} / \mathrm{ano}}$ & Energia mecânica gerada pela turbina ao ano & $52 \mathrm{TJ} / \mathrm{ano}$ & Equação 36 \\
\hline $\mathrm{E}_{\mathrm{e} / \mathrm{ano}}$ & Energia elétrica exportada por ano & $10,8 \mathrm{GWh}_{\mathrm{e}} /$ ano & Equação 37 \\
\hline $\mathrm{P}_{\mathrm{g}}$ & Potência elétrica de geração instalada & $2,3 \mathrm{MW}_{\mathrm{e}}$ & Equação 38 \\
\hline
\end{tabular}

Onde:

A energia elétrica exportada anualmente pelo sistema de incineração é $10,8 \mathrm{GWh}_{\mathrm{e}}$, sendo superior à produzida mediante biogás e calculada no cenário anterior $\left(6,6 \mathrm{GWh}_{\mathrm{e}}\right)$.

\subsubsection{Cenário 4: Biodigestão com concentração e uso veicular}

O Cenário 4 combina várias tecnologias apresentadas nos cenários anteriores, especificamente a concentração, a biodigestão e a geração elétrica com biogás, que será usada neste caso para suprir as cargas internas do sistema. Além disso, é incorporado um sistema de upgrading para a retirada do $\mathrm{CO}_{2}$ do biogás e um sistema de compressão para adequar o biometano extraído às características necessárias para seu uso veicular. Com esta combinação de tecnologias, é necessário o estudo do balanço energético global do sistema.

\section{Consumo elétrico na biodigestão e dessulfurifização no Cenário 4:}

O consumo elétrico do sistema de biodigestão e dessulfurização é idêntico ao calculado no Cenário 2, sendo de 1,2 $\mathrm{GWh}_{\mathrm{e}}$ no longo da safra (Equação 18).

Consumo elétrico purificação e compressão do biogás no Cenário 4::

A vazão de biogás saindo do biodigestor é de aproximadamente $1.000 \mathrm{Nm} 3 / \mathrm{h}$. Uma planta purificadora de biogás tipo water scrubber com esta capacidade tem uma potência instalada de $0,25 \mathrm{kWh} / \mathrm{m}^{3}$ de biogás (URBAN et al, 2009), consumindo no processo um máximo de $1.452 \mathrm{MWh} / \mathrm{ano}$. No que respeita à energia consumida para a compressão, um 
compressor de gás natural com pressão de entrada 4 bar e saída de 250 bar, com vazão de 735 $\mathrm{Nm}^{3} / \mathrm{h}$, precisa de um motor de $149 \mathrm{~kW}$ (GNC, 2014). Em consequência, por cada $\mathrm{Nm}^{3}$ comprimido são necessários $0,2 \mathrm{kWh}$. A partir desta referência, estima-se um consumo na compressão de $440 \mathrm{MWh}_{\mathrm{e}} / \mathrm{ano}$.

Consumo elétrico na concentração no Cenário 4:

O consumo elétrico da planta de concentração é idêntico ao calculado no Cenário 1, de $600 \mathrm{MWh}_{\mathrm{e}} / \mathrm{ano}$, por ter mesma capacidade.

\section{Consumo térmico na concentração no Cenário 4:}

Os gastos térmicos da concentração de vinhaça são os mesmos que no Cenário 1, utilizando as mesmas premissas para o sistema de evaporação. Como foi calculado anteriormente, o evaporador precisa 90,2 TJ/ano.

Consumo de combustível no transporte no Cenário 4:

Este consumo seria praticamente idêntico ao do Cenário 1, pois como já foi indicado, a biodigestão não reduz o volume. Assim, o consumo de combustível no transporte foi estimado em $126 \mathrm{~m}^{3}$ de diesel/ano ou 4,5 TJ/ano.

\section{Produção de biogás no Cenário 4:}

O volume de biogás produzido seria mesmo que no Cenário 2, estimado em 5,8 milhões de $\mathrm{Nm}^{3}$ biogás/ano. Parte deste biogás é destinado à produção de energia elétrica para suprir as cargas dos sistemas de biodigestão, concentração e tratamento do biogás (limpeza, purificação e compressão). Dessa forma, precisa-se calcular a quantidade necessária de biogás para abastecer um motogerador de $\eta_{\mathrm{e} / \mathrm{t}}=0,29$ (Equação 39).

$$
\frac{\left(\mathrm{C}_{\text {e.biod/ano }}+\mathrm{C}_{\text {e.purif/ano }}+\mathrm{C}_{\text {e.comp/ano }}+\mathrm{C}_{\text {e.conc/ano }}\right) / \eta_{\mathrm{e} / \mathrm{t}}}{\mathrm{PCI}_{\text {biogás }}}=
$$

\begin{tabular}{|c|c|c|c|}
\hline \multicolumn{4}{|c|}{ Dados de entrada } \\
\hline Símbolo & Significado & Valor & Fonte \\
\hline $\mathrm{C}_{\text {e.biod/ano }}$ & Consumo anual de eletricidade na biodigestão & 1.200 $\mathrm{MWh}_{\mathrm{e}} / \mathrm{ano}$ & Equação 18 \\
\hline $\mathrm{C}_{\text {e.purif/ano }}$ & Consumo anual de eletricidade na purificação & $1.452 \mathrm{MWh}_{\mathrm{e}} /$ ano & $\begin{array}{l}\text { URBAN et } \\
a l, 2009\end{array}$ \\
\hline $\mathrm{C}_{\text {e.comp/ano }}$ & Consumo anual de eletricidade na compressão & $581 \mathrm{MWh}_{\mathrm{e}} /$ ano & GNC, 2014 \\
\hline
\end{tabular}

Onde: 


\begin{tabular}{|c|c|c|c|}
\hline $\mathrm{C}_{\text {e.conc/ano }}$ & Consumo anual de eletricidade na concentração & $600 \mathrm{MWh}_{\mathrm{e}} /$ ano & Cenário 1 \\
\hline $\mathrm{PCI}_{\text {biogás }}$ & Poder Calorífico Inferior do biogás & $17.765 \mathrm{~kJ} / \mathrm{Nm}^{3}$ & Tabela 19 \\
\hline$\eta_{\mathrm{e} / \mathrm{t}}$ & Rendimento termoelétrico do gerador & 0,29 & \\
\hline \multicolumn{4}{|c|}{ Resultados } \\
\hline $\mathrm{C}_{\text {biogas.e/ano }}$ & Consumo anual de biogás na geração de eletricidade & $2.445 .000 \mathrm{Nm}^{3} / \mathrm{ano}$ & Equação 39 \\
\hline
\end{tabular}

Portanto, dos 5,8 milhões de $\mathrm{Nm}^{3}$ biogás/ano, praticamente 2,4 milhões seriam para a produção de energia elétrica consumida pelo próprio sistema e os 3,4 milhões restantes seriam destinados à compressão para suprir o consumo das operações de campo. Segue adiante o calculo da quantidade de diesel poderia ser substituído pelo biometano produzido (Equação 41).

$$
\begin{array}{cc}
\mathrm{Q}_{\text {biogás/ano }}= & \frac{\mathrm{V}_{\text {biogás/ano }}\left(1-\mathrm{V}_{\text {\%vaz }}\right)-\mathrm{C}_{\text {biogas.e/ano }}}{\mathrm{PCI}_{\text {biogás }}} \\
\mathrm{V}_{\text {diesel/ano }}=\frac{\mathrm{Q}_{\text {biogás/ano }}}{\mathrm{PCI}_{\text {diesel }}} & \text { Equação } 40
\end{array}
$$

\begin{tabular}{|c|c|c|c|}
\hline \multicolumn{4}{|c|}{ Dados de entrada } \\
\hline Símbolo & Significado & Valor & Fonte \\
\hline $\mathrm{PCI}_{\text {biogás }}$ & Poder Calorífico Inferior do biogás & $17.765 \mathrm{~kJ} / \mathrm{Nm}^{3}$ & Tabela 19 \\
\hline $\mathrm{PCI}_{\text {diesel }}$ & Poder Calorífico Inferior do diesel & $36.031 \mathrm{~kJ} / 1$ diesel & ANP, 2014 \\
\hline $\mathrm{V}_{\% \mathrm{vaz}}$ & Porcentagem de biogás vazado & $5 \%$ & \\
\hline $\mathrm{V}_{\text {biogás/ano }}$ & Volume de biogás produzido por ano & $5.800 .000 \mathrm{Nm}^{3} /$ ano & Equação 19 \\
\hline $\mathrm{C}_{\text {biogas.e/ano }}$ & Consumo anual de biogás na geração de eletricidade & $2.445 .000 \mathrm{Nm}^{3} /$ ano & Equação 39 \\
\hline \multicolumn{4}{|c|}{ Resultados } \\
\hline Q biogás/ano & Energia térmica do biogás disponível & $54 \mathrm{TJ} / \mathrm{ano}$ & Equação 40 \\
\hline $\mathrm{V}_{\text {diesel/ano }}$ & Volume equivalente de diesel produzido & $1.485 \mathrm{~m}^{3} /$ ano & Equação 41 \\
\hline
\end{tabular}

Onde:

Observa-se a importante quantidade de diesel que poderia ser substituída pelo biogás, quase $1500 \mathrm{~m} 3 / \mathrm{ano}$, onde o consumo de diesel para fertirrigação no cenário de referência (219 $\mathrm{m}^{3}$ de diesel/ano) seria $15 \%$ deste potencial.

\subsection{Resultados do balanço energético dos cenários considerados}

Os resultados obtidos nos cálculos do balanço energético nos diferentes cenários estão resumidos na Tabela 20. Esta tabela mostra o balanço térmico e elétrico em cada cenário, além do consumo de combustíveis, distinguindo sua origem fóssil ou renovável. Estes valores correspondem a uma usina de porte médio (Tabela 2), e com eles foram calculados os consumos específicos de energia por $\mathrm{m}^{3}$ de vinhaça, representados na Figura 31. 
No cenário de referência existe apenas o consumo de diesel. Este consumo de combustível fóssil é reduzido consideravelmente com a introdução da concentração, porém existe um importante consumo térmico na evaporação da água da vinhaça. Esta demanda térmica é suprida com vapor de processo ou com calor residual da usina e, em ambos os casos, o calor é produzido na caldeira alimentada com bagaço, sendo combustível renovável. O consumo de energia elétrica no concentrador não parece ser um fator importante, já que estes equipamentos precisam fundamentalmente de grande quantidade de energia térmica. Diante disso, a fonte desta energia é determinante para a viabilidade desta alternativa de tratamento

Tabela 20. Balanço energético em cada cenário para uma usina média $\left(960.000 \mathrm{~m}^{3}\right.$ de vinhaça/ano).

\begin{tabular}{lcccc}
\hline \multicolumn{1}{c}{ Cenário } & $\begin{array}{c}\text { Energia } \\
\text { térmica } \\
\text { (TJ/ano) }\end{array}$ & $\begin{array}{c}\text { Energia elétrica } \\
(\mathbf{G W h} / \mathbf{a n o})\end{array}$ & $\begin{array}{c}\text { Combustível fóssil } \\
\text { (TJ/ano) }\end{array}$ & $\begin{array}{c}\text { Combustível renovável } \\
\text { (TJ/ano) }\end{array}$ \\
\hline $\begin{array}{l}\text { 0. Fertirrigação in } \\
\text { natura }\end{array}$ & 0,0 & 0,0 & $-7,9$ & 0,0 \\
$\begin{array}{l}\text { 1. Concentração } \\
\begin{array}{l}\text { 2. Biodigestão }+ \\
\text { eletricidade }\end{array}\end{array}$ & $-90,2$ & $-0,6$ & $-4,5$ & $-90,2$ \\
$\begin{array}{l}\text { 3. Incineração + } \\
\text { eletricidade }\end{array}$ & $-21,0$ & 6,6 & $-7,9$ & 0,0 \\
$\begin{array}{l}\text { 4. Biodigestão }+ \\
\text { concentração }+\end{array}$ & $-90,2$ & 10,1 & $-42,0$ & 429,0 \\
uso veicular & 0,0 & & 54,0 \\
\hline
\end{tabular}

Fonte: Autor.

Nos cenários onde é produzida energia elétrica excedente para a sua comercialização, a incineração tem quase duas vezes mais produção do que a biodigestão. Na biodigestão tem-se o mesmo consumo de diesel do cenário de referência, já na incineração este consumo é totalmente eliminado. Apesar disso, na incineração é necessário um consumo de energia fóssil quase 7 vezes superior ao cenário de referência, por ser utilizado gás natural na queima da vinhaça. Ainda assim, a incineração possibilita o aproveitamento da vinhaça como combustível, gerando grande quantidade de energia térmica de origem renovável, que é aproveitada na própria concentração da vinhaça e na geração de energia elétrica. $O$ balanço energético do sistema de concentração - incineração não esta muito longe do equilíbrio, sendo levemente negativo, o que pode ser compensado com um aporte de calor residual por parte da usina. 
O cenário de uso veicular do biogás é o único dos cenários que não tem consumo de combustíveis fósseis. Além de gerar toda a energia elétrica para suprir as cargas internas do sistema de processamento, a produção de biometano é suficiente para abastecer os equipamentos utilizados nos trabalhos de fertirrigação e para substituir parte do consumo de diesel no restante das atividades relativas ao cultivo e transporte da cana-de-açúcar.

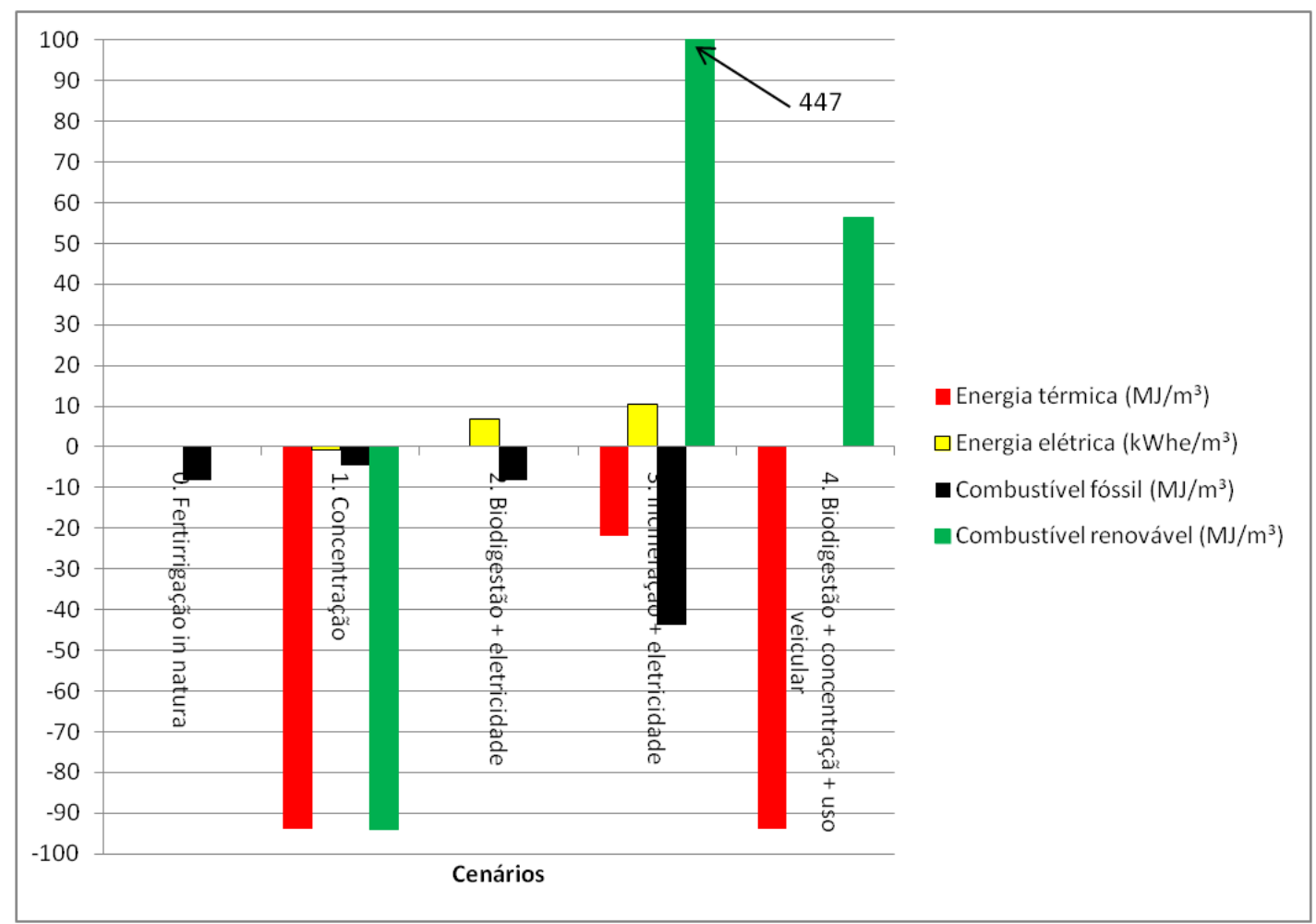

Figura 31. Balanço energético em cada cenário de tratamento da vinhaça em usinas de etanol de cana. Fonte: Autor.

Conclui-se que, do ponto de vista energético, o cenário mais recomendável é o Cenário 4, pela sua característica de ser $100 \%$ renovável. O biogás é utilizado para abastecer os veículos, o que melhora o balanço energético do etanol de cana-de-açúcar, chegando muito perto da completa independência dos combustíveis fósseis na sua produção.

Os resultados obtidos acima são utilizados no capítulo seguinte que estuda o impacto ambiental, pois com os valores calculados tanto de consumo de combustível fóssil e renovável, como de eletricidade e energia térmica, é possível calcular as emissões de GEEs e outros poluentes. Da mesma forma, os dados de produção e consumo de energia são fatores fundamentais a serem inseridos na avaliação econômica. 


\section{CAPÍTULO 4. AVALIAÇÃO DE IMPACTO AMBIENTAL}

O objetivo do presente capítulo é discutir os impactos mais importantes sobre o solo, a água e a atmosfera, que estariam atrelados aos diferentes cenários definidos no Capítulo 3. Para isso, foi realizada uma pesquisa bibliográfica aprofundando nos aspectos ambientais da fertirrigação, completando neste âmbito a descrição da técnica realizada no Capítulo 2. Partindo do cenário de referência, estudam-se quais são os benefícios ou os possíveis problemas ambientais que acompanham a implantação de cada uma das alternativas de processamento, inserindo os ganhos da produção energética na avaliação. Através da análise qualitativa e quantitativa, pretende-se comparar o desempenho ambiental dos diferentes cenários, com o intuito de determinar qual a tecnologia que implique maior mitigação de impactos com respeito ao cenário de referência da fertirrigação com vinhaça in natura.

\subsection{Solo e água}

\subsubsection{Cenário 0 de referência: Fertirrigação com vinhaça in natura}

Existem ainda dúvidas e controvérsias com relação aos impactos ambientais do uso da vinhaça in natura para fertirrigação, devido aos possíveis efeitos da vinhaça sobre o solo e a qualidade das águas subterrâneas quando usada em excesso. Nos estudos existentes há resultados variáveis em consequência da grande diversidade de solos e de composição das vinhaças, assim como de sua dosagem (SILVA et al., 2007).

Até o final dos anos setenta, a vinhaça era lançada nos corpos de água superficiais, esgotando o oxigênio dissolvido na água, destruindo os ecossistemas aquáticos e prejudicando o abastecimento de água, além de agravar endemias como a malária, a amebíase e a esquistossomose (ALMEIDA et al., 1950). Com o crescimento da produção nacional de etanol nos anos setenta e o aumento dos impactos ambientais, sociais e econômicos produzidos pelo despejo descontrolado de vinhaça nos rios, o governo instaurou a Portaria MINTER n ${ }^{\circ} 323$ de 29/11/1978, que proibia o lançamento (direto ou indireto) da vinhaça nos mananciais superficiais, obrigando as destilarias a apresentar projetos para implantação de sistemas de tratamento e/ou utilização da vinhaça (BRASIL, 1978). Nessa mesma direção, foi aprovada a resolução CONAMA n 0002 de 05/06/1984, que determinava a necessidade de realizar estudos para controle da poluição causada pelos efluentes das destilarias de álcool e pelas águas de lavagem da cana (CONAMA, 1984). Esta legislação permitiu o 
desenvolvimento de práticas mais razoáveis para a destinação da vinhaça, sendo desenvolvida a tecnologia nos anos seguintes para seu aproveitamento como fertilizante.

Outra destinação da vinhaça eram as chamadas "áreas de sacrifício", terrenos que recebiam enormes quantidades de vinhaça in natura. Como indica o termo, as "áreas de sacrifício" tornam-se completamente inutilizáveis para quaisquer outras finalidades, devido à salinização do solo. Além do impacto sobre o solo, esta prática pode causar a contaminação do lençol freático devido a possíveis infiltrações de substâncias poluentes, especialmente sais (potássio e nitratos).

Com relação à proteção dos aquíferos diante desta potencial contaminação, não foi encontrada legislação federal que regule o tratamento de efluentes industriais, tal como a vinhaça. Na esfera estadual, existe a Lei nº 6.134 de 02/06/1988, do Estado de São Paulo, que em seu art. $5^{\circ}$ estabelece que "os resíduos líquidos, provenientes de atividades industriais ou de qualquer outra natureza, só poderão ser conduzidos ou lançados de forma a não poluírem as águas subterrâneas" (SÃO PAULO, 1988). Em Minas Gerais foi aprovada a Deliberação Normativa do Conselho de Política Ambiental (COPAM) n. ${ }^{\circ}$ 012/86, a qual estabelece critérios para o armazenamento dos efluentes das destilarias e para a disposição de vinhaça no solo, fixando limites às doses de aplicação dependendo da origem do resíduo: caldo direto, melaço ou caldo misto de melaço e caldo de cana (COPAM, 1986). Esta legislação, foi aprovada depois de pesquisas como a de Glória e Magro (1977), que recomendaram dosagens controladas para o uso fertilizante de acordo com o teor de potássio $(\mathrm{K})$ contido na vinhaça e as condições dos solos e da cultura.

A CETESB, no Estado de São Paulo, regulamentou a fertirrigação com vinhaça através da Norma P4.231 (CETESB, 2006), estabelecendo os critérios e procedimentos para o armazenamento, transporte e aplicação. A Norma CETESB P4.231 inclui um conjunto de diretrizes que permitem orientar os produtores na aplicação da vinhaça nos solos de forma mais adequada e correta, no que tange à prevenção de impactos ambientais e à proteção ambiental, em especial, em relação às águas subterrâneas, ao solo, às Área de Preservação Permanente, às Áreas de Reserva Legal e aos núcleos urbanos próximos ao local (KLEIN et al., 2008). Posteriormente, em Minas Gerais, foi aprovada a Deliberação Normativa COPAM nº164, de 30 de março de 2011 (COPAM, 2011), sendo muito semelhante à Norma P4.231.

A Norma P4.231 estabelece o procedimento para calcular a dosagem máxima de vinhaça que pode receber uma determinada área, considerando a Capacidade de Troca 
Catiônica (CTC) ${ }^{31}$ do solo e a quantidade de potássio presente tanto no solo como no efluente. As restrições de dosagem podem ser um problema para as destilarias, que vêm incrementado o custo de dispersão da vinhaça, dado que devem de ampliar o seu raio de transporte.

Na Figura 32, representa-se o efeito da Norma P4.231, onde, na situação inicial, só seria atendida a necessidade de minimizar os custos de fertirrigação, sendo efetuada nos cultivos situados dentro de um pequeno raio de distribuição ou nas áreas onde sua dispersão for mais econômica, o que resulta em grandes doses de aplicação. Com a implantação da Norma P4.231 a dose passa a ser controlada e diminuída, incrementando o raio de distribuição e a superfície fertirrigada.

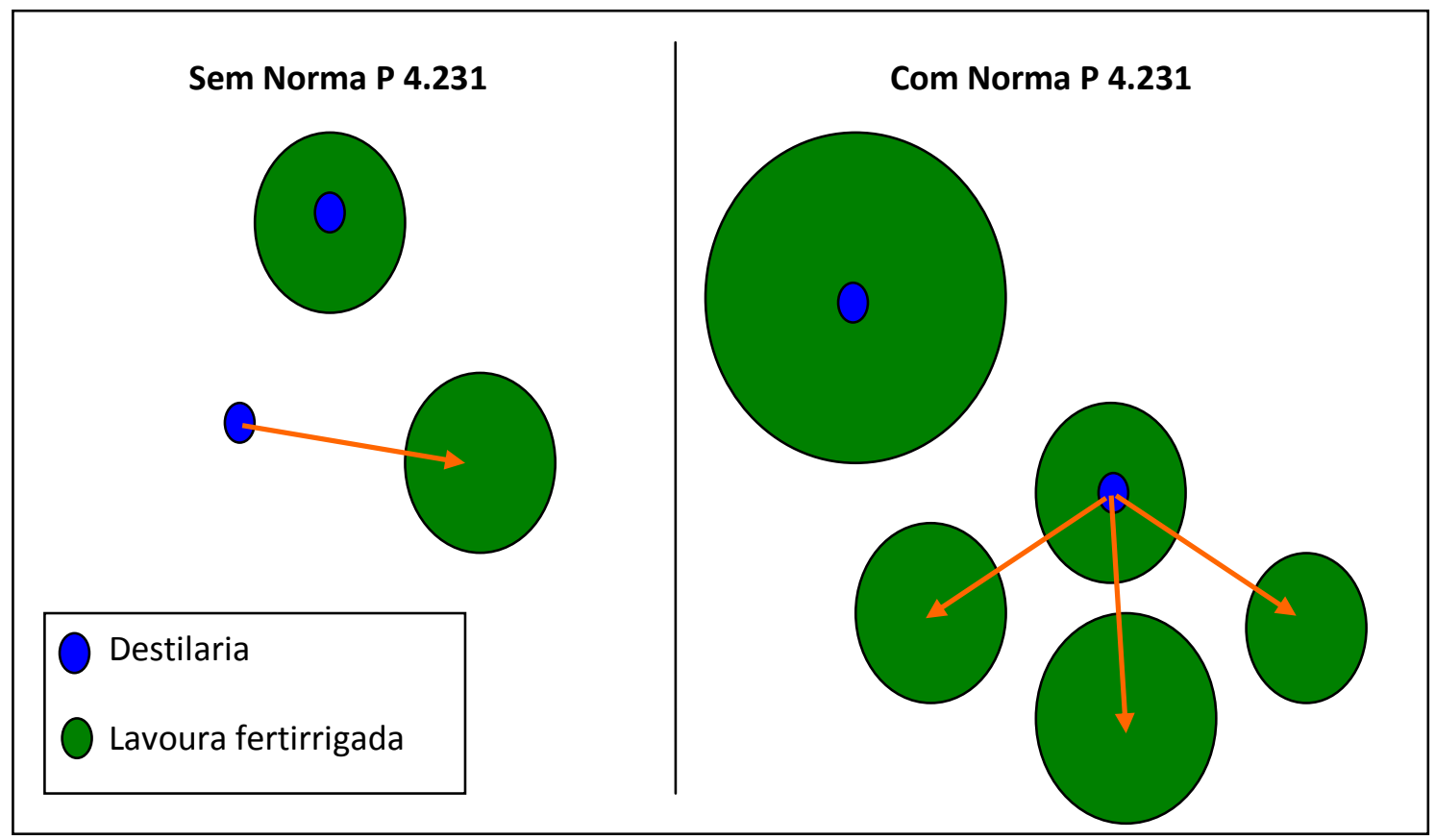

Figura 32. Representação esquemática do efeito da Norma P4.231 sobre a fertirrigação com vinhaça. Fonte: Autor.

Muitos autores estudaram os efeitos da vinhaça nos solos ao longo do tempo, concluindo que a vinhaça eleva o pH dos solos (ALMEIDA, 1950), aumenta a CTC pelo grande aporte de matéria orgânica (GLÓRIA; ORLANDO FILHO, 1983), fornece e aumenta a disponibilidade de alguns macronutrientes (BARROS et al., 2010), melhora a estrutura do solo, incrementa a retenção de água e amplia a atividade biológica promovendo maior número de insetos, minhocas, bactérias e fungos (FERREIRA \& MONTEIRO, 1987). Portanto, a vinhaça pode melhorar as características físico-químicas dos solos elevando sua fertilidade e produtividade de muitos solos cultivados com cana (WORKSHOP VINHAÇA, 2007).

\footnotetext{
${ }^{31}$ A Capacidade de Troca de Cátions (CTC) é o número total de cátions que o solo pode reter, o que depende da quantidade de cargas negativas presentes. Quanto maior é o número de cargas negativas de um solo, maior é a sua capacidade de troca de cátions ou de reter cátions.
} 
Apesar destes impactos positivos observados, quando a fertirrigação é realizada de forma inadequada pode ser um fator de vulnerabilidade para os aquíferos próximos da superfície. Com os enormes volumes manejados e transportados, a despesa da fertirrigação é determinante para a viabilidade econômica da produção de etanol, estimulando os usineiros a diminuir o raio de dispersão e produzindo uma excessiva dosagem nas áreas próximas à destilaria. Hassuda (1989), Cruz (1991), Righetto et alii. (1991) e Gloeden et alii. (1991) realizaram estudos sobre as possibilidades de contaminação das águas subterrâneas. Os resultados desses estudos indicam lixiviação de nutrientes da vinhaça em direção ao lençol freático, principalmente de nitratos, existindo um perigo de degradação futura desses aquíferos (CORAZZA, 2006).

O nitrato tem uma notória tendência de aumento nos Aquíferos Bauru, Pré-Cambriano e Serra Geral, desde o final dos anos noventa (Figura 33), sendo que o Bauru é o aquífero com maior concentração de nitrato (CETESB, 2013a), mas a relação entre este aumento dos níveis de nitrato e a prática da fertirrigação não foi estabelecida. Dessa forma, são necessários mais estudos para estabelecer correlações entre as concentrações de nitrato identificadas em poços e o uso e ocupação do solo.

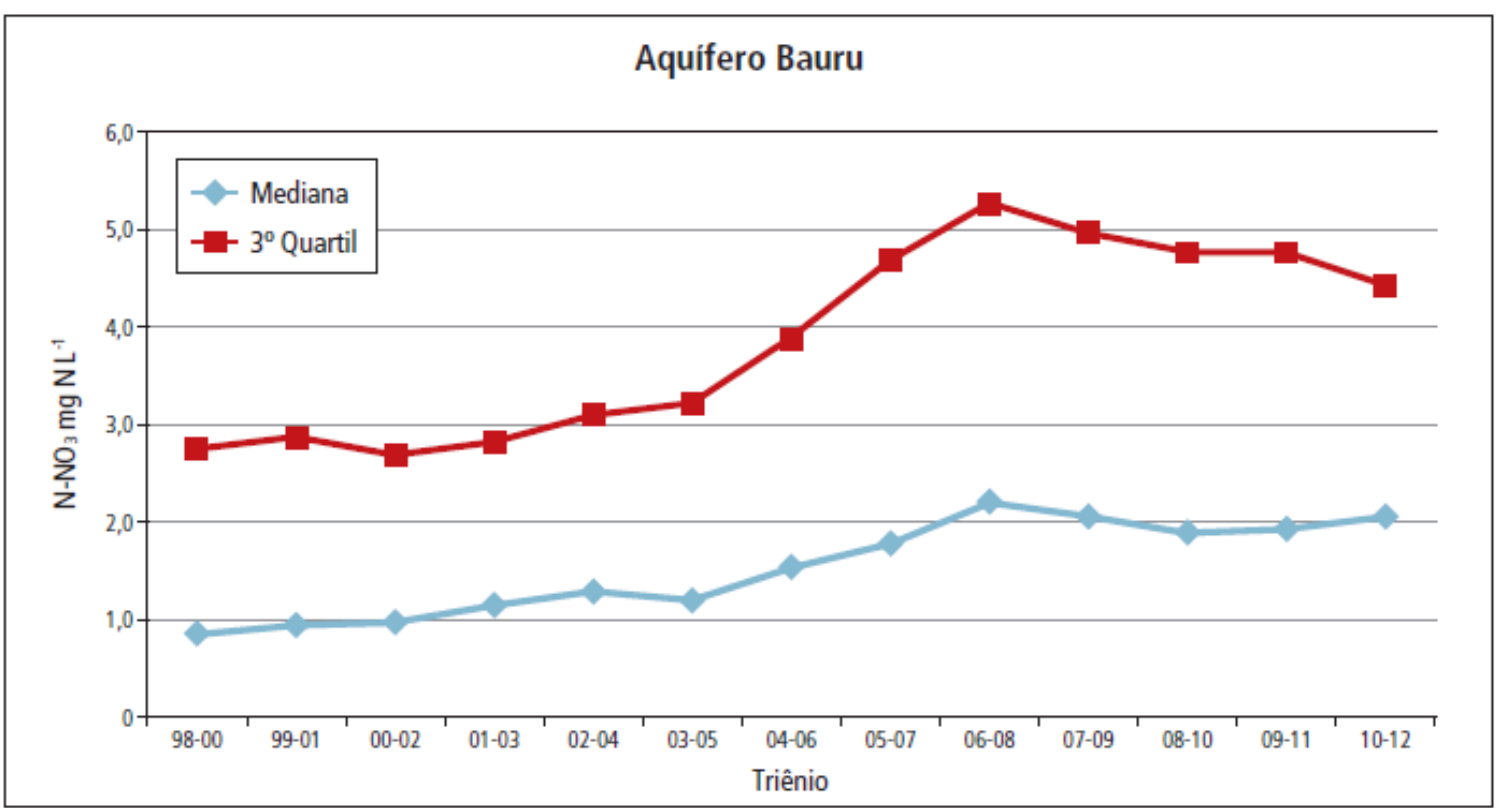

Figura 33. Tendência das concentrações de nitrato no Aquífero Bauru, no período de 1998 a 2012. Fonte: CETESB (2013).

No que tange a seu potencial como fertilizante, a vinhaça consegue suprir a necessidade de potássio da cana, mas não a de nitrogênio. Consequentemente, seu emprego reduz a depleção de recursos minerais necessária para a fertilização química, mas não a elimina totalmente. 
Aspectos pouco documentados são a presença de antibióticos ativos na vinhaça e os impactos que isto pode ocasionar no meio ambiente. $\mathrm{O}$ uso de antibióticos na produção de álcool tem sido a medida adotada pela indústria para controlar as infecções ocorridas nas dornas durante o processo de fermentação do caldo. Estas infecções são produzidas por bactérias provenientes do campo e transportadas junto com a cana. Estes microrganismos competem com a levedura pelo açúcar, comprometendo o rendimento da fermentação. Os tipos de antibióticos utilizados são em sua maioria resistentes à temperatura de destilação (termoestáveis), encontrando-se ativos depois do processo de destilação na vinhaça. $\mathrm{O}$ fato de que os antibióticos termoestáveis são os de uso mais difundido deve-se a sua maior economicidade se comparados aos termoláveis (BRASMETANO, 2011).

Na pesquisa realizada pela Brasmetano Ind. Com. Ltda. (2011) foram levantados os produtos utilizados no controle de infecção das dornas de fermentação que interferem no processo de produção do etanol (Tabela 21), constatando que a maioria destas substâncias tinha caráter termoestável.

Tabela 21. Tipos de antibióticos utilizados na fabricação do etanol

\begin{tabular}{llc}
\hline Produto & Classificação & $\begin{array}{c}\text { Temperatura de } \\
\text { Decomposição }{ }^{\circ} \mathbf{C}\end{array}$ \\
\hline Kamoran & Termoestável & 120 \\
Spectran 100E & Termoestável & 110 \\
HJ Gold & Termoestável & 120 \\
Kamoran WP & Termoestável & 110 \\
Kamoran HJ & Termoestável & 110 \\
Busan 978 & Termoestável & 120 \\
Busan 989 & Termoestável & 110 \\
AB 1030 & Termoestável & 120 \\
SM 3 & Termoestável & 120 \\
Kamoran & Termoestável & 110 \\
HJ Gold & Termoestável & 110 \\
Corstan & Termoestável & 110 \\
PVPOX 40 & Termolável & 65 \\
Spectran 100E & Termolável & 50 \\
Lúpulo Beta Ácido 45\% & Termolável & 55 \\
\hline
\end{tabular}

Fonte: Brasmetano Ind. Com. Ltda. (2011).

A dispersão de antibióticos no campo enseja a mutação dos microrganismos pela sobrevivência e pode produzir seletividade e resistência (BRASMETANO, 2011). A geração de microrganismos resistentes aos antibióticos disponíveis traz consequências significativas, tal como uma perda de eficiência no emprego destas substâncias para o controle biológico da fermentação. 


\subsubsection{Cenário 1: Concentração evaporativa}

A implantação da concentração da vinhaça mitiga alguns dos impactos produzidos pela fertirrigação, devido fundamentalmente à redução do seu volume.

Com a concentração reduz-se a necessidade de grandes depósitos para a vinhaça. Este armazenamento representa um perigo para o solo e para os corpos de água, considerando a possível percolação da vinhaça no sobsolo e, também, o rompimento acidental dos reservatórios que ocasiona graves impactos ambientais. Além de permitir a diminuição em 10 vezes o volume de armazenamento, a vinhaça concentrada não se deteriora em função de seu alto teor de sólidos solúveis, o que lhe confere um alto potencial osmótico impossibilitando sua biodegradabilidade (SILVA, 2012).

Ao diminuir o volume de vinhaça, existe uma necessidade menor no fluxo de caminhões e também uma redução das dimensões dos sistemas de deposito e canalização para o transporte, evitando movimento de terra para a construção desses sistemas e diminuindo o risco de rompimentos, vazamentos, e percolação.

A vinhaça concentrada é aplicada junto à linha de plantio, o que pode aumentar a eficiência da adubação caso a cana seja recém-plantada. Esta suposição assume que, caso as raízes não estejam desenvolvidas em toda a superfície do cultivo, a falta de absorção radicular permitiria uma maior percolação de nutrientes na entrelinha. Nesta condição, a perda do potássio e do nitrogênio parece mais provável com a aspersão realizada em toda a extensão que com a aplicação de vinhaça concentrada junto à linha de plantio.

Como tem sido indicado anteriormente, com a diminuição do volume se evitam perdas por vazamentos em lagoas e canais, o que aumentaria o controle na fertilização e o aproveitamento do adubo. Por outro lado, caso a distribuição da vinhaça concentrada aumente o trânsito de caminhões-tanque de elevado peso dentro do canavial, pode-se promover uma maior compactação do solo quando comparado com o sistema hidroroll. Deve-se resaltar que as suposições anteriores não estão fundamentadas em medições, fazendo-se necessária a sua verificação experimental.

Talvez um ponto fundamental para a expansão do uso de concentradores é que esta tecnologia possibilita a reutilização da água do condensado para a produção do álcool, diminuindo o consumo da planta e assim seu impacto ambiental. Com a atual preocupação no Estado de São Paulo ante a escassez de água e a ampliação da regulação pelo seu consumo no Brasil, a economia obtida com a implantação do processo de concentração surge como um dos principais benefícios dessa tecnologia, sendo importante incluir esta variável na análise de 
viabilidade do investimento em concentração (SANTA CRUZ, 2012). Este condensado possui concentrações mensuráveis de ácidos orgânicos, nitrogênio nítrico e amoniacal, assim como etanol, não podendo ser reutilizado como água de composição da caldeira de alimentação. Como esta água de reuso tem $\mathrm{pH}$ ácido, atualmente está sendo utilizada nas dornas de fermentação pelas suas propriedades antissépticas, diminuindo o consumo de antibióticos.

O Cenário 1 poderia diminuir a captação de água da usina em mais de 10\% (Equação 42 e Equação 43) com respeito do cenário de referência, considerando os dados de Santa Cruz (2012) acerca da captação de água e o reúso da totalidade do condensado obtido na evaporação da vinhaça.

$$
\begin{array}{cc}
\mathrm{V}_{\text {água/ano }}=\mathrm{m}_{\text {cana/ano }} \times \mathrm{V}_{\text {água/tcana }} & \text { Equação } 42 \\
\mathrm{~m}_{\text {cond/ano }}=\mathrm{V}_{\% \text { conc }} \times \mathrm{V}_{4^{\circ} \text { Bx } / \text { ano }} \times \mathrm{m}_{\text {cond } / \mathrm{V} 4^{\circ} \mathrm{Bx}} & \text { Equação } 43
\end{array}
$$

\begin{tabular}{|c|c|c|c|}
\hline \multicolumn{4}{|c|}{ Dados de entrada } \\
\hline Símbolo & Significado & Valor & Fonte \\
\hline $\mathrm{V}_{4^{\circ} \mathrm{Bx} / \mathrm{ano}}$ & Volume de vinhaça $4^{\circ} \mathrm{Bx}$ produzido por ano & $960.000 \mathrm{~m}^{3} /$ ano & Tabela 2 \\
\hline $\mathrm{m}_{\mathrm{cond} / \mathrm{V} 4^{\circ} \mathrm{Bx} \mathrm{l}}$ & Água condensada por $\mathrm{m}^{3}$ de $\mathrm{V}_{4^{\circ} \mathrm{Bx}}$ concentrada até $\mathrm{V}_{20^{\circ} \mathrm{Bx}}$ & $811,2 \mathrm{~kg} / \mathrm{m}^{3}$ & Tabela 15 \\
\hline $\mathrm{V}_{\% \text { conc }}$ & Porcentagem de volume concentrado & $29 \%$ & Tabela 14 \\
\hline $\mathrm{V}_{\text {água/tcana }}$ & Volume de água captada por tonelada de cana & $1,85 \mathrm{~m}^{3}$ & $\begin{array}{l}\text { Santa Cruz, } \\
2012\end{array}$ \\
\hline $\mathrm{m}_{\text {cana/ano }}$ & Massa de cana processada por ano & $1.160 .000 \mathrm{t}$ & Tabela 2 \\
\hline \multicolumn{4}{|c|}{ Resultados } \\
\hline $\mathrm{V}_{\text {água/ano }}$ & Volume de água captada por ano & $2.150 .000 \mathrm{~m}^{3} / \mathrm{ano}$ & Equação 42 \\
\hline $\mathrm{m}_{\text {con/ano }}$ & Vapor condensado por ano & $226.000 \mathrm{~m}^{3} /$ ano & Equação 43 \\
\hline
\end{tabular}

Onde:

Considerando que na região sudeste do país a cana não é irrigada e tem como única fonte de água a precipitação natural da região e a vinhaça, deve ser apontado que a fertirrigação pode ser importante para o plantio em determinados momentos de escassez de chuva como recurso para realizar a chamada "irrigação de salvamento"32.

\subsubsection{Cenário 2: Biodigestão anaeróbia com geração de eletricidade}

Como foi mencionado anteriormente, uma das vantagens da biodigestão da vinhaça é que seu potencial de fertilização continua sendo praticamente o mesmo após o processo, fazendo com que a vinhaça biodigerida possa ser levada ao campo para a fertirrigação. Por esta conservação dos nutrientes, principalmente do conteúdo de potássio, fósforo e nitrogênio, evita-se a aplicação de fertilizantes minerais. Estudos indicam que potencial fertilizador da

\footnotetext{
${ }^{32}$ Irrigação realizada após a colheita ou plantio da cultura.
} 
vinhaça não só se mantém, como também aumenta, dado que a vinhaça digerida tem uma maior proporção de nitrogênio amoniacal. Sparks (1995) apud Jadoski et al. (2010) descreve que para o nitrogênio na forma de amônio $\left(\mathrm{NH}^{4+}\right)$, a lixiviação é reduzida pela adsorção deste cátion no complexo de cargas negativas do solo.

Por outro lado, neste processo se perderiam os benefícios mencionados sobre a incorporação de matéria orgânica no solo, produzida com a fertirrigação com vinhaça in natura, pois o processo de biodigestão elimina a maior parte da mesma. Desse modo, quando se pensa na aplicação no solo, a diminuição da carga orgânica é uma desvantagem para a fertilização.

A acidificação temporária do solo produzida com a fertirrigação com vinhaça in natura pode ser evitada com a biodigestão, dado que se produz um aumento importante do $\mathrm{pH}$ da vinhaça que atinge valor neutro.

Um impacto colateral positivo a ser considerado é a necessidade de eliminar o uso de antibióticos termoestáveis no controle da fermentação alcoólica, com o fim de viabilizar o processo de biodigestão da vinhaça. Supondo que os ganhos econômicos derivados da produção e do uso de biogás fossem superiores aos custos de substituição de antibióticos termostáveis, a biodigestão seria uma opção para evitar a emissão desses compostos ativos na natureza. No presente estudo, não foi incluída uma análise de viabilidade econômica desta substituição pela dificuldade de se obter dados reais sobre o uso de antibióticos, tais como quantidades ou compostos aplicados.

Depois da biodigestão, o volume de vinhaça continua sendo o mesmo e em consequência, mantêm-se os impactos produzidos pelo seu transporte. Para evitar a concentração de nutrientes, tais como o potássio, nas imediações das usinas e para o cumprimento da Norma CETESB P4.231 Dez/2006, é necessária a criação de um sistema de distribuição de vinhaça a longas distâncias, com os movimentos de terra necessários para a construção de lagoas de armazenamento e canais de distribuição. O perigo de salinização de solos e aquíferos continua presente, pois as quantidades de potássio permanecem na biodigestão. Observa-se que a eliminação da carga orgânica não é total, possuindo ainda potencial poluidor de águas.

\subsubsection{Cenário 3: Incineração com geração de eletricidade}

Com o processo da incineração de vinhaça, evitam-se todos os problemas associados à distribuição da vinhaça, assim como os possíveis riscos de contaminação de corpos de água e do lençol freático, eliminando-se totalmente a necessidade de verter um efluente líquido com 
alto DQO e conteúdo em sais no meio ambiente. Com esta tecnologia se obtém um fertilizante sólido constituído por sais de potássio solúveis, facilmente transportável e aplicável, evitando a compra de fertilizantes químicos.

Um ganho importante associado a este sistema é devido à concentração da vinhaça necessária para sua combustão, pois a água proveniente dos condensadores pode ser reutilizada no processo de fabricação do etanol, diminuindo significativamente o consumo de água por parte da usina. Neste cenário concentra-se $100 \%$ da vinhaça até atingir $65^{\circ} \mathrm{Bx}$, o que significa que, para a usina modelo, existe uma disponibilidade de água de reúso de 913.536 $\mathrm{m}^{3}$ /ano. Utilizando o dado de consumo de $1,85 \mathrm{~m}^{3} / \mathrm{t}$ de cana (SANTA CRUZ, 2012), chega-se a um volume de reúso calculado de $42 \%$ da água captada pela usina.

Finalmente, com a incineração, eliminam-se totalmente os resíduos de antibióticos ativos presentes na vinhaça e seus impactos potenciais atrelados.

\subsubsection{Cenário 4: Biodigestão com concentração e uso veicular}

Com esta solução combinada, unem-se o desempenho ambiental da biodigestão com o da concentração. Com a concentração, diminui-se o volume da vinhaça, facilitando sua distribuição a longas distâncias e, com a biodigestão, reduz-se a carga orgânica. Por tanto, este sistema controla simultaneamente a concentração de potássio no entorno das usinas, favorecendo assim o cumprimento da Norma CETESB P4.231, e a possibilidade de contaminação da água com matéria orgânica.

Possibilita-se também a reutilização da água na produção do álcool ou no processo da biodigestão. Além dos benefícios anteriores, a vinhaça biodigerida e concentrada tem boas características para seu uso fertilizante, eliminando parcialmente a aplicação de adubos minerais.

É fundamental que a vinhaça in natura não contenha antibióticos ativos que prejudiquem a biodigestão. Sendo assim, a implantação deste sistema incentiva a substituição de antibióticos termoestáveis por técnicas menos perigosas para o meio ambiente.

\subsection{Emissões de GEEs}

A fertirrigação com vinhaça possui um alto potencial de emissão de GEEs (MCTI, 2013), devido ao seu importante conteúdo em carbono e em nutrientes, sendo microbiologicamente ativa por sua DBO e por seu conteúdo em nitrogênio. Como a vinhaça é armazenada em lagoas e transportada em canais a céu aberto, existem emissões de metano em consequência à decomposição anaeróbia desta matéria orgânica. Apesar disto, no balanço de 
GEEs realizado para o etanol de cana-de-açúcar por Macedo et al. (2008), os autores consideram que devido à vinhaça não permanecer em lagoas e ao volume de aplicação no campo ser controlado, não se promovem condições anaeróbicas. Portanto, os autores assumem que as emissões de metano não são significativas, sendo excluídas de seu cálculo.

Em outro trabalho sobre balanço de GEEs para etanol de cana-de-açúcar, elaborado por Soares (2009), indica-se que na época não existiam ainda dados sobre a emissão de $\mathrm{CH}_{4}$ produzida durante o tratamento de vinhaça por fertirrigação. Porém, este mesmo autor assinala que, devido à significativa quantidade de material orgânico e de nutrientes carregado na vinhaça, assim como à sua mistura com a água da lavagem da cana que é contaminada com algo de açúcar, poderia resultar em emissões de $\mathrm{CH}_{4}$. Levando isso em conta, Soares (2009) considera que, após a aplicação da vinhaça na lavoura, não se espera emissão de $\mathrm{CH}_{4}$ do solo, mas inclui no cálculo um valor de emissão de $\mathrm{CH}_{4}$ nos canais de distribuição de $0,2 \%$ do carbono contido na vinhaça.

Com a finalidade de obter dados empiricos sobre emissões de $\mathrm{CH}_{4}$ durante o processo de fertirrigação têm sido realizados diversos estudos. Nas medições realizadas pela Embrapa Agrobiologia (BODDEY, 2009) foram constatadas emissões de metano em um canal de distribuição de vinhaça, chegando a 185,5 $\mathrm{g} \mathrm{CH}_{4} / \mathrm{m}^{2}$ hora. As medições de Paredes (2011) monstraram que o armazenamento e a distribuição de vinhaça por lagoas e canais podem ser fontes de $\mathrm{CH}_{4}$, sendo os canais de terra a principal via de perda. Esses dados também indicam que o percentual de carbono presente na vinhaça emitido na forma de $\mathrm{CH}_{4}$ pode chegar a $33 \%$, sendo que a presença de lodo acumulado nos reservatórios tem efeito na amplificação das emissões. Como pode ser observado, o valor obtido por Paredes (2011) está bem acima do estimado por Soares et al. (2009). Oliveira (2010) corroborou sua hipótese de que a vinhaça é uma fonte de GEEs ao medir emissões de $\mathrm{CH}_{4}$ no canal de até $1.684 \mathrm{mg}$ de $\mathrm{CH}_{4} / \mathrm{m}^{2}$ hora.

Apesar de serem estudos pontuais, de escassa representatividade, com poucas medições e com grande variação nos resultados quantitativos, os estudos citados apontam na mesma direção, corroborando a hipótese de que em lagoas e canais provavelmente são promovidas condições de anaerobiose, com uma significativa emissão de $\mathrm{CH}_{4}$ que não esta sendo considerada no inventário de GEEs do setor do etanol.

Nesta seção, realiza-se uma estimativa das emissões de GEEs em cada cenário, calculando as emissões evitadas com a implantação de cada uma das tecnologias avaliadas. Este cálculo só contabilizará as emissões de $\mathrm{CO}_{2}$ provenientes de combustíveis fósseis e as de 
$\mathrm{CH}_{4}$ relativas ao tratamento e à distribuição da vinhaça, não incluindo as emissões de oxido nitroso $\left(\mathrm{N}_{2} \mathrm{O}\right)$ existentes em lagoas e canais.

A decisão de não incluir esta emissão de $\mathrm{N}_{2} \mathrm{O}$ tem dois motivos. $\mathrm{O}$ primeiro é que, segundo dados de Oliveira (2010), o $\mathrm{CH}_{4}$ é responsável por 99,84\% da emissão do $\mathrm{CO}_{2} \mathrm{eq}$ produzida no sistema de distribuição, deixando ao $\mathrm{N}_{2} \mathrm{O}$ uma participação considerada insignificante. Por outro lado, não existem dados disponíveis de emissão de $\mathrm{N}_{2} \mathrm{O}$ quando se distribui vinhaça biodigerida ${ }^{33}$.

Neste estudo tampouco foram consideradas as emissões de $\mathrm{CH}_{4}$ e $\mathrm{N}_{2} \mathrm{O}$ produzidas no solo da lavoura. Com relação às emissões de $\mathrm{CH}_{4}$ provenientes do solo fertirrigado, existem evidências que corroboram a hipótese de que a aplicação de vinhaça geralmente não resulta em emissões significativas de $\mathrm{CH}_{4}$ (PAREDES, 2011; CARMO et al. ,2013; OLIVEIRA et al., 2013), indicando que a matéria orgânica é descomposta no solo em condições aeróbicas.

No que se refere às emissões de $\mathrm{N}_{2} \mathrm{O}$ no solo, existem resultados controversos sobre os fatores de emissão do nitrogênio presente na vinhaça. Lisboa et al. (2011) e Carmo et al. (2013) encontraram fatores de emissão superiores ao valor de $1 \%$ considerado pelo IPCC, enquanto as medições de Oliveira et al. (2013) indicaram o contrário. Em qualquer caso, os resultados mostram maior importância relativa das emissões de $\mathrm{CH}_{4}$ em lagoas e canais quando comparadas às emissões de $\mathrm{N}_{2} \mathrm{O}$ no solo, até o ponto em que estas se tornam desprezíveis.

Por outro lado, devido à falta de dados acerca da fertirrigação empregando vinhaça concentrada ou biodigerida, não é possível realizar uma comparação entre estes tratamentos. Portanto, será assumido que todos os cenários têm a mesma emissão de $\mathrm{N}_{2} \mathrm{O}$ no solo, não afetando a comparação.

Por estas razões, no presente trabalho serão analisadas apenas as emissões de $\mathrm{CH}_{4}$ provenientes das lagoas e canais, assunto ainda não considerado com detalhe na literatura, de modo que nãoformam encontradas publicações revisadas.

\subsubsection{Cenário 0 de referência: Fertirrigação com vinhaça in natura}

As emissões de GEEs produzidas neste cenário são tomadas como linha de base para o cálculo de reduções nos demais casos estudados. Neste cálculo são contabilizadas as emissões de $\mathrm{CH}_{4}$ que se produzem em lagoas de armazenamento e canais de distribuição, assim como as emissões de $\mathrm{CO}_{2}$ provenientes do consumo de diesel na distribuição de vinhaça.

\footnotetext{
${ }^{33}$ Esta dissertação se baseia em dados de revisão bibliográfica.
} 
Emissões de $\mathrm{CH}_{4}$ em lagoas e canais no Cenário 0 :

Para estimar as emissões produzidas em lagoas e canais, são utilizados dados não submetidos a ampla revisão, usando como referências dissertações de mestrado ao carecer de outras fontes disponíveis.

Nos estudos de Paredes (2011) e de Oliveira (2010), realizou-se amostragem e caracterização química da vinhaça em diferentes pontos de um canal de distribuição. Em ambos os estudos, observou-se uma queda acentuada nos valores de DBO e DQO da vinhaça com o aumento da distância percorrida no canal condutor. Esta diminuição na quantidade de carbono orgânico é um indicativo das reações de decomposição, que ocasionaram emissões gasosas de $\mathrm{CO}_{2}$ e $\mathrm{CH}_{4}$. Esta diminuição é especialmente significativa entre o ponto do canal anterior à lagoa e o posterior, indicando que existe uma maior decomposição de matéria orgânica nos lugares de armazenamento. As medições de Oliveira (2010) mostram que a DQO da vinhaça se reduz em $29 \%$ no passo pela lagoa (Tabela 22). Além disso, nas lagoas existe maior possibilidade de anaerobiose, já que estes reservatórios chegam a ter profundidades de até 5 metros, existindo acumulação de lodo no fundo, além de possuir uma temperatura propícia para microrganismos termofílicos e mesofílicos.

No presente estudo, utilizam-se os dados coletados por Oliveira (2010) para contabilizar a diminuição de carbono orgânico da vinhaça no sistema de distribuição (Tabela 22). Observa-se uma diminuição na concentração de potássio nas amostras, o que significa que a vinhaça está sendo diluída no percurso, pois o potássio se encontra dissolvido e não é sedimentado ou retirado de nenhuma forma. Uma explicação para esta diluição pode ser a captação de água de chuva no canal proveniente do escoamento superficial. Esta diluição é calculada para cada secção do canal, considerando que a concentração de potássio se deveria manter constante em todos eles se a captação de água não se produzisse.

Tabela 22. Composição da vinhaça $\mathrm{kg} / \mathrm{m}^{3}$ em diferentes secções do canal.

\begin{tabular}{lccccc}
\hline & DBO & DQO & C & K & $\begin{array}{c}\text { Fator de } \\
\text { Diluição* }\end{array}$ \\
\hline Seção inicial & 14,97 & 31,15 & 10,17 & 3,28 & 1,00 \\
Secção depois da lagoa & 3,57 & 11,06 & 3,47 & 1,65 & 1,99 \\
Secção final & 1,48 & 6,86 & 1,42 & 0,84 & 3,91 \\
\hline
\end{tabular}

Fonte: Oliveira (2010).

* Calculado pelo autor considerando a concentração de potássio. 
Utilizando o coeficiente de diluição calculado, pode-se corrigir a estimativa da quantidade de carbono orgânico que é perdido na passagem pela lagoa e no percurso do canal, assim como sua porcentagem, resultados mostrados na Tabela 23.

Tabela 23. Composição da vinhaça $\mathrm{kg} / \mathrm{m}^{3} \mathrm{em}$ diferentes secções do canal ajustando a diluição.

\begin{tabular}{lccccc}
\hline & DBO & DQO & C & K & $\begin{array}{c}\text { Fator de } \\
\text { Diluição }\end{array}$ \\
\hline Tramo inicial & 14,97 & 31,15 & 10,17 & 3,28 & 1,00 \\
Tramo depois da lagoa & 7,10 & 22 & 6,9 & 3,28 & 1,00 \\
Tramo final & 5,81 & 26,83 & 5,54 & 3,28 & 1,00 \\
\hline
\end{tabular}

Fonte: Cálculo do autor baseado nos dados de Oliveira (2010).

A questão central que deve ser esclarecida é sobre quanto carbono contido é emitido em forma de $\mathrm{CH}_{4}$. A diversidade de configurações e dimensões que podem ter as lagoas e os canais de distribuição dificulta a tarefa de dar uma porcentagem representativa de matéria orgânica emitida como $\mathrm{CH}_{4}$. Para dar uma estimativa da emissão deste gás na lagoa, é utilizada a metodologia ACM0014 "Treatment of wastewater",34.

Segundo esta metodologia, o cálculo das emissões de $\mathrm{CH}_{4}$ nas lagoas é baseado na DQO utilizando os parâmetros da Equação 45. A DQO eliminada na lagoa depende de vários fatores, tais como as dimensões da lagoa, o tempo de residência, a carga orgânica de entrada, a temperatura ambiente e da vinhaça, etc. Como foi indicado anteriormente, no caso particular estudado por Oliveira (2010), a DQO da vinhaça se reduz em 29\%. Seguindo esta referência por falta de estudos mais abrangentes, assume-se que a vinhaça é descarregada na lagoa com $31,15 \mathrm{~kg}$ de DQO $/ \mathrm{m}^{3}$ de vinhaça, saindo deste armazenamento com $22 \mathrm{~kg}$ de $\mathrm{DQO} / \mathrm{m}^{3}$ (Tabela 23). Desse modo, são eliminados $9,15 \mathrm{~kg}$ de DQO $/ \mathrm{m}^{3}$ de vinhaça durante o tempo de residência na lagoa. Por outro lado, considera-se uma capacidade de produção máxima de metano de 0,21 kg CH$/ \mathrm{kg}$ DQO (CLNSA, 2009). Para o cálculo de $\mathrm{F}_{\mathrm{DQO} / \mathrm{CH} 4}$ (Equação 44), utilizam-se os valores indicados na metodologia ACM0014, que toma como 50\% a fração de degradação sob condições anaeróbicas, existentes em lagoas de profundidade maior a 1,5 m. Esta metodologia assume uma reação anaeróbia completa com valores superiores a $30^{\circ} \mathrm{C}$, sendo este o caso da vinhaça. Inclui-se no cálculo um fator de incerteza conservador de 0,89 . Com estes valores, pode ser estimada a emissão de $\mathrm{CH}_{4}$ de $0,86 \mathrm{~kg} \mathrm{CH}_{4} / \mathrm{m}^{3}$ de vinhaça (Equação 45).

\footnotetext{
${ }^{34}$ Metodologia aprovada pela UNFCCC (ONU, 2012).
} 


$$
\begin{array}{ll}
\mathrm{F}_{\mathrm{DQO} / \mathrm{CH} 4}=0,5 \times 1 \times 0,89=0,45 & \text { Equação } 44 \\
\mathrm{CH}_{4}=\mathrm{DQO}_{\mathrm{e}} \times \mathrm{B}_{\mathrm{o}} \times \mathrm{F}_{\mathrm{DQO} / \mathrm{CH} 4} & \text { Equação } 45
\end{array}
$$

\begin{tabular}{|c|c|c|c|}
\hline \multicolumn{4}{|c|}{ Dados de entrada } \\
\hline Símbolo & Significado & Valor & Fonte \\
\hline $\mathrm{B}_{\mathrm{o}}$ & Capacidade de produção máxima de metano & $0,21 \mathrm{~kg} \mathrm{CH}_{4} / \mathrm{kg}$ DQO & $\begin{array}{l}\text { CLNSA, } \\
2009\end{array}$ \\
\hline $\mathrm{DQO}_{\mathrm{e}}$ & DQO eliminada por $\mathrm{m}^{3}$ de vinhaça na lagoa & $9,15 \mathrm{~kg} / \mathrm{m}^{3}$ & \\
\hline \multicolumn{4}{|c|}{ Resultados } \\
\hline $\mathrm{F}_{\mathrm{DQO} / \mathrm{CH} 4}$ & Fator de conversão da DQO em metano & 0,45 (Adimensional) & Equação 44 \\
\hline $\mathrm{CH}_{4}$ & Emissão de $\mathrm{CH}_{4}$ por cada $\mathrm{m}^{3}$ de vinhaça & $0,86 \mathrm{~kg} / \mathrm{m}^{3}$ & Equação 45 \\
\hline
\end{tabular}

Onde:

Considerando as massas atômicas do metano e do carbono ${ }^{35}$, dos $0,86 \mathrm{~kg} \mathrm{CH}_{4} / \mathrm{m}^{3}$ de vinhaça, 0,65 kg correspondem à massa do carbono. Como pode ser deduzido dos dados do carbono presente na vinhaça (Tabela 23), existe uma perda deste elemento de $3,2 \mathrm{~kg} \mathrm{C} / \mathrm{m}^{3}$ de vinhaça durante a residência na lagoa. Desta perda, $0,65 \mathrm{~kg}$ são emitidos na forma de $\mathrm{CH}_{4}$, e o restante é emitido na forma de $\mathrm{CO}_{2}$ ou fixado na biomassa dos microrganismos. Portanto, o valor da emissão de carbono na forma de $\mathrm{CH}_{4}$ representa 6,4\% do Carbono inicialmente presente na vinhaça.

Quanto à emissão de $\mathrm{CH}_{4}$ produzida no canal, assume-se o valor estimado por Oliveira (2010), de $0,11 \mathrm{~kg} \mathrm{CH} / \mathrm{m}^{3}$ de vinhaça, equivalendo a $0,08 \mathrm{~kg} \mathrm{C} / \mathrm{m}^{3}$ de vinhaça, o que representa $0,8 \%$ do carbono inicialmente presente na vinhaça.

Os fatores calculados acima são resumidos na Tabela 24, onde pode ser observado que a emissão na lagoa é significativa.

Tabela 24. Carbono eliminado da vinhaça e emitido na forma de $\mathrm{CH}_{4} \mathrm{em}$ lagoas e canais.

\section{\% de Carbono eliminado \% de Carbono emitido na forma de $\mathrm{CH}_{4}$}

$\begin{array}{lll}\text { Lagoa } & 32,2 & 6,4\end{array}$
Canal
13,3
0,8

Fonte: Autor.

Aplicando estes coeficientes de emissão e o valor médio de $10 \mathrm{~kg}$ de carbono $/ \mathrm{m}^{3} \mathrm{de}$ vinhaça (Tabela 3), obtêm-se a emissão por $\mathrm{m}^{3}$ de vinhaça na lagoa e no canal (Equação 47).

\footnotetext{
${ }^{35}\left[\mathrm{CH}_{4}\right]=16 \mathrm{~g} / \mathrm{mol} ;[\mathrm{C}]=12 \mathrm{~g} / \mathrm{mol}$
} 
Para saber qual é a emissão de GEEs deste cenário, deve-se considerar que 29\% da vinhaça é transportada em caminhão, evitando-se a emissão de $\mathrm{CH}_{4}$ nos canais. Assim, calcula-se a quantidade de $\mathrm{CO}_{2}$ equivalente emitido por $\mathrm{m}^{3}$ de vinhaça no Cenário 0 (Equação $46 \mathrm{e}$ Equação 47):

$$
\begin{array}{cc}
\mathrm{m}_{\mathrm{CH} 4 / \mathrm{V} 4^{\circ} \mathrm{Bx}}=\mathrm{m}_{\mathrm{C} / \mathrm{V} 4^{\circ} \mathrm{Bx}} \times \mathrm{F}_{\mathrm{C} / \mathrm{CH} 4} \times \frac{\mathrm{M}_{\mathrm{CH} 4}}{\mathrm{M}_{\mathrm{C}}} & \text { Equação } 46 \\
\mathrm{CO}_{2} \mathrm{eq}_{\mathrm{ano}}=\left(1-\mathrm{V}_{\% \mathrm{cam}}\right) \times \mathrm{m}_{\mathrm{CH} 4 / \mathrm{V} 4^{\circ} \mathrm{Bx}} \times \mathrm{F}_{\mathrm{CH} 4 / \mathrm{CO} 2 \mathrm{eq}} & \text { Equação } 47
\end{array}
$$

\begin{tabular}{|c|c|c|c|}
\hline \multicolumn{4}{|c|}{ Dados de entrada } \\
\hline Símbolo & Significado & Valor & Fonte \\
\hline $\mathrm{m}_{\mathrm{C} / \mathrm{V} 4^{\circ} \mathrm{Bx}}$ & Carbono contido por $\mathrm{m}^{3}$ vinhaça & $10 \mathrm{~kg}$ & Tabela 3 \\
\hline $\mathrm{M}_{\mathrm{C}}$ & Massa molecular do carbono & $12 \mathrm{~g} / \mathrm{M}$ & \\
\hline $\mathrm{M}_{\mathrm{CH} 4}$ & Massa molecular do metano & $14 \mathrm{~g} / \mathrm{M}$ & \\
\hline $\mathrm{F}_{\mathrm{C} / \mathrm{CH} 4}$ & Fator de conversão do carbono em metano & $\begin{array}{l}\text { lagoa: } 6,4 \% \text {; } \\
\text { canal: } 0,8 \%\end{array}$ & Tabela 24 \\
\hline $\mathrm{F}_{\mathrm{CH} 4 / \mathrm{CO} 2 \mathrm{eq}}$ & Fator de conversão do $\mathrm{CH}_{4} \mathrm{em} \mathrm{CO}{ }_{2} \mathrm{eq}$ & 21 & IPCC, 2006 \\
\hline $\mathrm{V}_{\text {\%cam. }}$ & Volume de vinhaça transportado em caminhão & $\begin{array}{l}\text { lagoa: } 0 \% ; \\
\text { canal: } 29 \%\end{array}$ & Tabela 5 \\
\hline \multicolumn{4}{|c|}{ Resultados } \\
\hline $\mathrm{m}_{\mathrm{CH} 4 / \mathrm{V} 4^{\circ} \mathrm{Bx}}$ & Metano emitido por $\mathrm{m}^{3}$ vinhaça & $\begin{array}{l}\text { lagoa: } 0,86 \mathrm{~kg} / \mathrm{m}^{3} \\
\text { canal: } 0,11 \mathrm{~kg} / \mathrm{m}^{3}\end{array}$ & Equação 46 \\
\hline $\mathrm{CO}_{2} \mathrm{eq}_{\mathrm{ano}}$ & Emissão anual por $\mathrm{m}^{3}$ de vinhaça & $\begin{array}{l}\text { lagoa } 17,86 \mathrm{~kg} / \mathrm{m}^{3} \text { ano; } \\
\text { canal } 1,58 \mathrm{~kg} / \mathrm{m}^{3} \text { ano } \\
\text { Total: } 19,44 \mathrm{~kg} / \mathrm{m}^{3} \text { ano }\end{array}$ & Equação 47 \\
\hline
\end{tabular}

Onde:

Com estes resultados, observa-se a significativa emissão de $\mathrm{CO}_{2} \mathrm{eq}$ que pode ser produzida por ano pela vinhaça em forma de $\mathrm{CH}_{4}$. Estendendo este resultado a uma usina média das características descritas na Tabela 2, a emissão seria de $18.700 \mathrm{tCO}_{2} \mathrm{eq} / \mathrm{ano}$, e para todo o setor sucroalcooleiro no Estado de São Paulo, seria de quase 3 milhões de $\mathrm{tCO}_{2} \mathrm{eq} / \mathrm{ano}$, se os dados da literatura aqui utilizados puderem ser generalizados.

Emissão de $\mathrm{CO}_{2}$ por consumo de combustíveis fósseis no Cenário 0:

Como foi calculado anteriormente no balanço energético, na fertirrigação são consumidos $30 \mathrm{~L}$ de diesel /ha ou $0,228 \mathrm{~L} / \mathrm{m}^{3}$ de vinhaça. Tomando a emissão total no ciclo de vida do diesel, dada por Macedo et al. (2004), e a densidade do diesel, obtém-se a emissão causada pelos motores diesel (Equação 48). 


$$
\mathrm{CO}_{2} \mathrm{eq}_{\text {diesel/ano }}=\mathrm{C}_{\text {diesel } / \mathrm{V} 4^{\circ} \mathrm{Bx}} \times \rho_{\text {diesel }} \times \mathrm{CO}_{2} \mathrm{eq}_{\text {diesel }} \quad \text { Equação } 48
$$

Onde:

\begin{tabular}{|c|c|c|c|}
\hline \multicolumn{4}{|c|}{ Dados de entrada } \\
\hline Símbolo & Significado & Valor & Fonte \\
\hline $\mathrm{C}_{\text {diesel/V4} 4^{\circ} \mathrm{Bx}}$ & Consumo de diesel por $\mathrm{m}^{3}$ de vinhaça $4^{\circ} \mathrm{Bx}$ por ano & $0,228 \mathrm{~L} / \mathrm{m}^{3}$ ano & Equação 3 \\
\hline$\rho_{\text {diesel }}$ & Densidade do diesel & $840 \mathrm{~kg} / \mathrm{m}^{3}$ & BEN, 2006 \\
\hline $\mathrm{CO}_{2} \mathrm{eq}_{\text {diesel }}$ & Emissão de $\mathrm{CO}_{2}$ eq por kg de diesel & $3,49 \mathrm{kgCO}_{2} \mathrm{eq} / \mathrm{kg}_{\text {diesel }}$ & $\begin{array}{l}\text { Macedo et } \\
\text { al., } 2004\end{array}$ \\
\hline \multicolumn{4}{|c|}{ Resultados } \\
\hline $\mathrm{CO}_{2} \mathrm{eq}_{\text {diesel } / \mathrm{m}^{3}}$ & $\begin{array}{l}\text { Emissão de } \mathrm{CO}_{2} \text { eq por } \mathrm{m}^{3} \text { de vinhaça proveniente } \\
\text { do diesel }\end{array}$ & $0,668 \mathrm{kgCO}_{2} \mathrm{eq} / \mathrm{m}^{3}$ & Equação 48 \\
\hline
\end{tabular}

Com o resultado obtido, calcula-se que uma usina média com consumo anual de 219 $\mathrm{m}^{3}$ de diesel para realizar a fertirrigação, emitiria $642 \mathrm{tCO}_{2} \mathrm{eq}$, valor insignificante quando comparado à emissão obtida para as lagoas.

\subsubsection{Cenário 1: Concentração evaporativa}

\section{Emissões de $\mathrm{CH}_{4}$ em lagoas e canais no Cenário 1:}

Neste cenário, o volume de vinhaça que chega até à lagoa é diminuído, já que parte do mesmo é encaminhado na usina para ser submetido a sua concentração e seu transporte por caminhão. Considera-se que a vinhaça concentrada e transportada em caminhão não sofre decomposição e, dessa forma, a redução de emissões de $\mathrm{CH}_{4}$ é proporcional à porcentagem do volume que receve tratamento. No modelo proposto, $71 \%$ do volume continuaria indo para a lagoa, assim esperar-se uma redução de $29 \%$ nas emissões produzidas por esta fonte. As emissões do canal permanecem idênticas que no Cenário de referência, pois o volume de vinhaça transportado por eles continua sendo o mesmo. Isto significa que, no Cenário 1, são emitidas $13,80 \mathrm{kgCO}{ }_{2} \mathrm{eq} / \mathrm{m}^{3}$ em lagoas e canais, ou $13.250 \mathrm{tCO}_{2} \mathrm{eq} / \mathrm{m}^{3}$ ano em uma usina média.

\section{Emissão de $\mathrm{CO}_{2}$ por consumo de combustíveis fósseis no Cenário 1:}

No Cenário 1 ocorre uma redução do uso de diesel empregado no transporte da vinhaça, visto que com a concentração o volume a transportar é menor. Como foi calculado no balanço energético, para uma usina média no Cenário 0 são consumidos por ano $219 \mathrm{~m}^{3}$ de diesel, enquanto no Cenário 1 o consumo anual é de $126 \mathrm{~m}^{3}$ de diesel. Esta diferença de $93 \mathrm{~m}^{3}$ de 
diesel/ano significa uma redução de $43 \%$, passando de $0,668 \mathrm{kgCO}_{2} \mathrm{eq} / \mathrm{m}^{3}$ para 0,386 $\mathrm{kgCO}{ }_{2} \mathrm{eq} / \mathrm{m}^{3}$ de vinhaça.

Emissão de GEEs por consumo de eletricidade no Cenário 1:

Segundo os cálculos realizados no Capítulo 5 de balanço energético, é necessário reduzir $0,625 \mathrm{kWh} / \mathrm{m}^{3}$ a exportação para o SIN, sendo esta a energia produzida no sistema de cogeração da usina e consumida pelo concentrador. Considerando uma Intensidade de Carbono na Geração Elétrica Brasileira (ICGEB) de $82 \mathrm{kgCO}_{2} \mathrm{eq} / \mathrm{MWh}^{36}$, as emissões por conta desta eletricidade que deixaria de ser exportada - passando a ser suprida pelo SIN - são de $0,051 \mathrm{kgCO}{ }_{2} \mathrm{eq} / \mathrm{m}^{3}$ de vinhaça.

\subsubsection{Cenário 2: Biodigestão anaeróbia com geração de eletricidade}

\section{Emissões de $\mathrm{CH}_{4}$ em lagoas e canais no Cenário 2:}

Neste cenário são considerados os dados levantados por Cortez et al. (1998), na Usina São Martinho, onde a vinhaça entra com 29 g/l de DQO e o efluente de saída possui 9 g/l, o que significa uma redução do $65 \%$ da matéria orgânica. Admite-se que, após a digestão anaeróbia no reator, a vinhaça biodigerida praticamente cessa de emitir $\mathrm{CH}_{4}$, a não ser aquele que se encontra dissolvido na mesma, uma vez que o carbono orgânico passível de transformação é consumido durante a biodigestão.

A quantidade de $\mathrm{CH}_{4}$ dissolvido e que está presente nas amostras de vinhaça tomadas por Paredes (2011) foi em média de 2,55 $\mathrm{g} \mathrm{CH}_{4} / \mathrm{m}^{3}$ de vinhaça ou $0,054 \mathrm{kgCO}_{2} \mathrm{eq} / \mathrm{m}^{3}$. Estes valores são pouco significativos, a pesar da consideração de que todo o $\mathrm{CH}_{4}$ dissolvido fosse emitido. Por outro lado, o vazamento do biodigestor possui pode possuir relevância, aplicando um fator de $5 \%$ da produção total de $\mathrm{CH}_{4}$. Segundo foi determinado no balanço energético, a produção no biodigestor é de $3 \mathrm{Nm}^{3}$ de $\mathrm{CH}_{4}$ por cada $\mathrm{m}^{3}$ de vinhaça, e consequentemente a perda por vazamento é de $0,15 \mathrm{Nm}^{3}$ de $\mathrm{CH}_{4}$ ou $2,268 \mathrm{kgCO}_{2} \mathrm{eq} / \mathrm{m}^{3}$ de vinhaça.

Emissão de $\mathrm{CO}_{2}$ por consumo de combustíveis fósseis no Cenário 2:

Como foi visto no balanço energético, o consumo de diesel na distribuição da vinhaça no Cenário 2 seria idêntico ao produzido no cenário de referência, portanto, 0,668 $\mathrm{kgCO}{ }_{2} \mathrm{eq} / \mathrm{m}^{3}$ de vinhaça.

\footnotetext{
${ }^{36}$ Dado referente a 2012 (BEN, 2013).
} 
Emissão de GEEs evitada por produção de energia elétrica:

Utilizando o valor de produção de eletricidade calculada no balanço energético e a ICGEB de $82 \mathrm{kgCO}_{2}$ eq/MWh (BEN, 2013), tem-se uma redução de emissões de 0,564 $\mathrm{kgCO}_{2} \mathrm{eq} / \mathrm{m}^{3}$ de vinhaça.

\subsubsection{Cenário 3: Incineração com geração de eletricidade}

Emissões de CH4 em lagoas e canais no Cenário 3:

Neste cenário, as emissões em lagoas e canais são evitadas por ser eliminado completamente o volume da vinhaça. Assume-se que todo seu conteúdo em matéria orgânica é transformado em $\mathrm{CO}_{2}$ através da combustão, desta forma seria eliminada praticamente a emissão de $\mathrm{CH}_{4}$ quando comparada à do Cenário de referência. $\mathrm{O} \mathrm{CO}_{2}$ emitido na combustão da vinhaça não é contabilizado, já que, ao ser incinerada matéria orgânica fixada previamente pela cana de açúcar, o ciclo do carbono é fechado.

Emissão de $\mathrm{CO}_{2}$ por consumo de combustíveis fósseis no Cenário 3:

Da mesma forma, a distribuição por caminhão seria desnecessária, evitando-se também a emissão proveniente do diesel. Conforme indicado anteriormente, a distribuição das cinzas resultantes da incineração é realizada junto à sulcação e à adubação, sendo esta uma operação agrícola independente do tratamento da vinhaça. Por outro lado, ao ser utilizado o gás natural como combustível suporte para a queima da vinhaça, devem ser contabilizadas suas emissões. Adotando o valor das emissões do IPCC (2006) de 64,2 $\mathrm{tCO}_{2} \mathrm{eq} / \mathrm{TJ}$ e aplicando o valor obtido no balanço energético para o consumo de gás natural, tem-se uma emissão de 2,85 $\mathrm{kgCO}_{2} \mathrm{eq} / \mathrm{m}^{3}$ de vinhaça.

Emissão de GEEs evitada por produção de energia elétrica no Cenário 3:

Utilizando o mesmo método do Cenário 2, pode-se calcular que, com a energia elétrica produzida no sistema de cogeração e exportada para o SIN, seria evitada a emissão de 0,923 $\mathrm{kgCO}_{2} \mathrm{eq} / \mathrm{m}^{3}$ de vinhaça.

\subsubsection{Cenário 4: Biodigestão com concentração e uso veicular}

Este cenário agrega a redução de emissões obtidas nos Cenários 1 e 2, incluindo também a substituição do diesel por $\mathrm{CH}_{4}$ proveniente do biogás na frota da usina. 
Emissões de $\mathrm{CH}_{4}$ no Cenário 4:

Neste Cenário 4 tem-se as mesmas perdas fugitivas de $\mathrm{CH}_{4}$ no biodigestor que no Cenário 2, de 2,268 $\mathrm{kgCO}_{2} \mathrm{eq} / \mathrm{m}^{3}$ de vinhaça.

Emissão de $\mathrm{CO}_{2}$ evitado por produção de metano para uso veicular no Cenário 4:

A emissão proveniente do consumo de diesel é eliminada, consequência tanto da diminuição do volume distribuído, obtido pela concentração, quanto da substituição do diesel por biometano procedente do biogás. Se este biometano for utilizado como combustível veicular nas atividades de cultivo e de transporte da cana, obtém-se uma redução de 4,535 $\mathrm{kgCO}_{2} \mathrm{eq} / \mathrm{m}^{3}$ de vinhaça.

\subsection{Emissões de $\mathrm{NO}_{x}$ e $\mathrm{SO}_{\mathrm{x}}$}

Os óxidos de nitrogênio e enxofre $\left(\mathrm{NO}_{\mathrm{x}}\right.$ e $\left.\mathrm{SO}_{\mathrm{x}}\right)$ liberados nos processos de combustão nas caldeiras industriais, nas usinas termelétricas e nos motores de veículos, são considerados agentes da chuva ácida. Pela sua importância no rol das emissões antropogênicas no mundo, decidiu-se incorporar neste estudo as estimativas de $\mathrm{NO}_{\mathrm{x}}$ e $\mathrm{SO}_{\mathrm{x}}$ produzidas pelos equipamentos de combustão, tais como os motores a diesel e a biogás e como o incinerador de vinhaça, utilizadas nos respectivos cenários, complementando o cálculo das emissões de GEEs.

\subsubsection{Cenário 0 de referência: Fertirrigação com vinhaça in natura}

Para o cálculo da emissão de $\mathrm{NO}_{\mathrm{x}}$, aplicam-se os fatores para veículos com motor de ciclo diesel em 2009 (CETESB, 2013) e os valores definidos na Tabela 5, que descreve os sistemas de aplicação de vinhaça nas lavouras de cana-de-açúcar do Estado de São Paulo. No cenário de referência são utilizados caminhões semipesados, pesados e motores estacionários para bombear a vinhaça, sendo calculadas suas emissões de $\mathrm{NO}_{\mathrm{x}}$ na Tabela 25.

A concentração de óxidos de enxofre no gás de escape é diretamente proporcional ao teor de enxofre presente no óleo diesel. A concentração de $\mathrm{SO}_{2}$ pode ser calculada, com uma boa exatidão, pelo consumo de combustível e seu teor de enxofre. Durante a combustão, todo o enxofre contido no óleo diesel é oxidado. Quase tudo é emitido como $\mathrm{SO}_{2}$, mas uma pequena fração (2 a 3\%) é convertida em trióxido de enxofre $\left(\mathrm{SO}_{3}\right)$ no escapamento, o qual reage facilmente com a água para formar o ácido sulfúrico $\left(\mathrm{H}_{2} \mathrm{SO}_{4}\right)$ (CAPANA, 2008). 
Tabela 25. Cálculo das emissões de $\mathrm{NO}_{\mathrm{x}}$ no Cenário 0 de referência.

\begin{tabular}{|c|c|c|c|c|c|c|c|}
\hline $\begin{array}{l}\text { Sistema de } \\
\text { transporte e } \\
\text { aplicação }\end{array}$ & Maquinaria & $\begin{array}{c}\% \text { de } \\
\text { Volumen de } \\
\text { vinhaça }\end{array}$ & $\begin{array}{c}\text { Volume de } \\
\text { vinhaça }\end{array}$ & $\begin{array}{c}\text { Distância } \\
\text { média ou } \\
\text { tempo de } \\
\text { funcionamento }\end{array}$ & $\begin{array}{c}\text { Distância total } \\
\text { ou energia } \\
\text { consumida }\end{array}$ & $\begin{array}{c}\text { Fator de } \\
\text { emissão de NO} \mathrm{O}_{\mathbf{x}} \\
(\mathrm{g} / \mathbf{k m} \text { ou } \\
\mathrm{g} / \mathbf{k W h})\end{array}$ & $\begin{array}{l}\text { Emissão de } \\
\text { NO }_{x}(\text { t/ano })\end{array}$ \\
\hline $\begin{array}{l}\text { Caminhão } \\
\text { Semipesado } \\
\text { aplicando } \\
\text { diretamente }\end{array}$ & $\begin{array}{l}\text { MB2318 com } \\
\text { tanque de } 15 \mathrm{~m}^{3}\end{array}$ & $5 \%{ }^{a}$ & $48.000^{c}$ & $7 \mathrm{~km}^{\mathrm{a}}$ & $44.800 \mathrm{~km}^{\mathrm{c}}$ & $5,23 \mathrm{~g} / \mathrm{km}^{\mathrm{b}}$ & $0,23^{\mathrm{c}}$ \\
\hline \multirow{2}{*}{$\begin{array}{l}\text { Caminhão } \\
\text { Pesado com } \\
\text { aspersão } \\
\text { combinado com } \\
\text { motobomba }\end{array}$} & $\begin{array}{l}\text { Volvo rodotrem } \\
\text { com dois tanques } \\
\text { de } 30 \mathrm{~m}^{3} / \text { cada }^{\text {a }}\end{array}$ & \multirow[t]{2}{*}{$24 \%^{a}$} & \multirow[t]{2}{*}{$230.400^{\mathrm{c}}$} & $12 \mathrm{~km}^{\mathrm{a}}$ & $184.320 \mathrm{~km}^{\mathrm{c}}$ & $5,14 \mathrm{~g} / \mathrm{km}^{\mathrm{b}}$ & $0,95^{\mathrm{c}}$ \\
\hline & $\begin{array}{l}\text { Motobomba } \\
120 \mathrm{~kW}\end{array}$ & & & $1.646 \mathrm{~h}^{\mathrm{c}}$ & $197.486 \mathrm{kWh}^{\mathrm{c}}$ & $4,72 \mathrm{~g} / \mathrm{kWh}^{\mathrm{b}}$ & $0,93^{\mathrm{c}}$ \\
\hline $\begin{array}{l}\text { Sistema de } \\
\text { aspersão } \\
\text { aplicando }\end{array}$ & $\begin{array}{l}\text { Motobomba } 120 \\
\mathrm{~kW} \text { em canal com } \\
\text { montagem direta } \\
\text { ou com rolão }^{\mathrm{a}}\end{array}$ & $71 \%^{\mathrm{a}}$ & $681.600^{\mathrm{c}}$ & $4.869 \mathrm{~h}^{\mathrm{c}}$ & $584.229 \mathrm{kWh}^{\mathrm{c}}$ & $4,72 \mathrm{~g} / \mathrm{kWh}^{\mathrm{b}}$ & $2,76^{\mathrm{c}}$ \\
\hline TOTAL & & $100 \%$ & $960.000^{d}$ & & - & & $4,87^{c}$ \\
\hline
\end{tabular}

Fonte: a) Tabela 5; b) CETESB (2013); c) Calculado pelo autor; d) Tabela 2.

Atualmente, os tipos de óleo diesel comercializados no território nacional são diferenciados basicamente pelos teores máximos de enxofre: S50 (50 ppm de enxofre) e S500 (500 ppm de enxofre). Nas áreas rurais, onde se encontram as usinas, é comercializado o S500. Deste modo, para o cálculo das emissões de $\mathrm{SO}_{\mathrm{x}}$, considera-se que $500 \mathrm{mg}$ de enxofre são emitidos como consequência do consumo de um kg de diesel.

$$
\mathrm{SO}_{2 \text { diesel } / \mathrm{m}^{3}}=\mathrm{C}_{\text {diesel } / \mathrm{V} 4^{\circ} \mathrm{Bx}} \times \rho_{\text {diesel }} \times \mathrm{S}_{\text {diesel }} \times \frac{\mathrm{M}_{\mathrm{S}}}{\mathrm{M}_{\mathrm{SO} 2}} \quad \text { Equação } 49
$$

Onde:

\section{Dados de entrada}

$\begin{array}{llll}\text { Símbolo } & \text { Significado } & \text { Valor } & \text { Fonte } \\ \mathrm{C}_{\text {diesel/V44Bx }} & \text { Consumo de diesel por } \mathrm{m}^{3} \text { de vinhaça } 4^{\circ} \mathrm{Bx} \text { por ano } & 0,228 \mathrm{~L} / \mathrm{m}^{3} \text { ano } & \text { Equação 3 } \\ \rho_{\text {diesel }} & \text { Densidade do diesel } & 840 \mathrm{~kg} / \mathrm{m}^{3} & \text { BEN, 2006 } \\ \mathrm{S}_{\text {diesel }} & \text { Quantidade de enxofre por kg de diesel } & 500 \mathrm{mg} / \mathrm{kg}_{\text {diesel }} & \\ \mathrm{M}_{\mathrm{S}} & \text { Massa molecular do enxofre } & 32 \mathrm{~g} / \mathrm{M} & \\ \mathrm{M}_{\mathrm{SO} 2} & \text { Massa molecular do } \mathrm{SO}_{2} & 64 \mathrm{~g} / \mathrm{M} & \end{array}$

\section{Resultados}

$\mathrm{SO}_{2 \text { diesel } / \mathrm{m}^{3}} \quad$ Emissão de $\mathrm{SO}_{2}$ por $\mathrm{m}^{3}$ de vinhaça proveniente do diesel

$\mathrm{Na}$ Tabela 26, aparecem resumidas as emissões do Cenário 0 por cada $\mathrm{m}^{3}$ de vinhaça tratada e as produzidas anualmente pela usina de referência, diferenciando a fonte de emissão e, posteriormente, agregando-as para ser calculado o balanço resultante. 
Tabela 26. Emissões gasosas no Cenário 0

\begin{tabular}{|c|c|c|c|c|c|c|}
\hline \multirow[b]{2}{*}{ Fonte } & \multicolumn{2}{|c|}{$\mathrm{CO}_{2} \mathrm{eq}$} & \multicolumn{2}{|c|}{$\mathrm{NO}_{\mathrm{x}}$} & \multicolumn{2}{|c|}{$\mathbf{S O}_{\mathrm{x}}$} \\
\hline & $\begin{array}{c}\text { Por } \mathrm{m}^{3} \text { de } \\
\text { vinhaça } \\
(\mathrm{kg})\end{array}$ & $\begin{array}{c}\text { Anual } \\
(t)\end{array}$ & $\begin{array}{c}\text { Por } \mathbf{m}^{3} \text { de } \\
\text { vinhaça } \\
(\mathrm{g})\end{array}$ & $\begin{array}{c}\text { Anual } \\
(\mathbf{t})\end{array}$ & $\begin{array}{c}\text { Por } \mathbf{m}^{3} \text { de } \\
\text { vinhaça } \\
\text { (g) }\end{array}$ & $\begin{array}{c}\text { Anual } \\
(t)\end{array}$ \\
\hline Lagoas e canais & 19,44 & $18.700,00$ & 0,00 & 0,00 & 0,00 & 0,00 \\
\hline Motores diesel & 0,67 & 642,00 & 5,10 & 4,87 & 0,19 & 0,18 \\
\hline TOTAL & 20,11 & $19.342,00$ & 5,10 & 4,87 & 0,19 & 0,18 \\
\hline
\end{tabular}

Fonte: Autor.

\subsubsection{Cenário 1: Concentração evaporativa}

De forma similar ao cálculo da emissão de NOx que foi realizado no cenário de referência, aplicam-se os fatores para veículos com motor de ciclo diesel em 2009 (CETESB, 2013b) e os valores definidos na Tabela 17 que descrevem a aplicação de vinhaça no Cenário 1. Neste cenário são utilizados caminhões semipesados que aplicam a vinhaça concentrada $20^{\circ} \mathrm{Bx}$ e motores estacionários para bombear a vinhaça in natura. O cálculo das emissões de NOx destes equipamentos é mostrado na Tabela 27.

Tabela 27. Calculo das emissões de $\mathrm{NO}_{\mathrm{x}}$ no Cenário 1.

\begin{tabular}{|c|c|c|c|c|c|c|c|}
\hline $\begin{array}{l}\text { Sistema de } \\
\text { transporte e } \\
\text { aplicação }\end{array}$ & Maquinaria & $\begin{array}{c}\% \text { de } \\
\text { Volume de } \\
\text { vinhaça }\end{array}$ & $\begin{array}{l}\text { Volume de } \\
\text { vinhaça }\end{array}$ & $\begin{array}{l}\text { Distância média } \\
\text { ou tempo de } \\
\text { funcionamento }\end{array}$ & $\begin{array}{c}\text { Distáncia } \\
\text { total ou } \\
\text { energia } \\
\text { consumida }\end{array}$ & $\begin{array}{c}\text { Fator de } \\
\text { emissão de NO } \\
(\mathrm{g} / \mathbf{k m} \text { ou } \\
\text { g/kWh })\end{array}$ & $\begin{array}{l}\text { Emissão de } \\
\text { NO }_{x}(\text { t/ano })\end{array}$ \\
\hline $\begin{array}{l}\text { Caminhão } \\
\text { Semipesado } \\
\text { aplicando } \\
\text { diretamente }\end{array}$ & $\begin{array}{l}\text { MB2318 com } \\
\text { tanque de } 15 \mathrm{~m}^{3}\end{array}$ & $29 \%$ & $\begin{array}{l}52.400 \\
\left(\mathrm{~V}_{20^{\circ} \mathrm{Bx}}\right)\end{array}$ & $11,19 \mathrm{~km}$ & $78.181 \mathrm{~km}$ & $5,23 \mathrm{~g} / \mathrm{km}$ & 0,41 \\
\hline $\begin{array}{l}\text { Sistema de } \\
\text { aspersão }\end{array}$ & $\begin{array}{l}\text { Motobomba } 120 \\
\mathrm{~kW} \text { em canal com } \\
\text { montagem direta } \\
\text { ou com rolão }\end{array}$ & $71 \%$ & $\begin{array}{l}681.600 \\
\left(\mathrm{~V}_{4^{\circ} \mathrm{Bx}}\right)\end{array}$ & $4.869 \mathrm{~h}$ & $\begin{array}{l}584.229 \\
\mathrm{kWh}\end{array}$ & $4,72 \mathrm{~g} / \mathrm{kWh}$ & 2,76 \\
\hline TOTAL & & $100 \%$ & - & - & - & & 3,17 \\
\hline
\end{tabular}

Fonte: Autor.

Com respeito às emissões de SOx, utilizando a Equação 49 e o consumo de diesel deste cenário, tem-se uma emissão de 105,8 $\mathrm{kgSO}_{2} /$ ano ou $110,26 \mathrm{mgSO} / \mathrm{m}^{3}$ de vinhaça.

Além destas emissões, deve ser incrementado o valor de $600 \mathrm{MWh}_{\mathrm{e}}$ correspondente ao consumo de energia elétrica proveniente da rede. Utilizando os dados da Tabela 28, chega-se à emissão de $54 \mathrm{kgNO}_{\mathrm{x}} / \mathrm{ano}$ e de $230 \mathrm{kgSO}_{\mathrm{x}} / \mathrm{ano}$ por conta do consumo elétrico no concentrador. 
Tabela 28. Emissão de $\mathrm{NO}_{\mathrm{x}}$ e $\mathrm{SO}_{\mathrm{x}}$ da geração elétrica do Brasil.

\begin{tabular}{ccc}
\hline Poluente & Emissão total $(\mathbf{t})$ & Emissão especifica $(\mathbf{g} / \mathbf{M W h})^{*}$ \\
\hline $\mathrm{NO}_{\mathrm{x}}$ & 17.823 & 89,29 \\
$\mathrm{SO}_{\mathrm{x}}$ & 76.481 & 383,17 \\
\hline
\end{tabular}

Fonte de dados: Eletrobrás (2012), ano base 2011.

*Cálculo utilizando a geração líquida no Brasil de 2011 (199.601.937 MWh, Eletrobrás, 2012)

Na Tabela 29, aparecem resumidas as emissões do Cenário 1, da mesma forma como foi feito no Cenário 0.

Tabela 29. Emissões gasosas no Cenário 1

\begin{tabular}{|c|c|c|c|c|c|c|}
\hline \multirow[b]{2}{*}{ Fonte } & \multicolumn{2}{|c|}{$\mathrm{CO}_{2} \mathrm{eq}$} & \multicolumn{2}{|c|}{$\mathrm{NO}_{\mathrm{x}}$} & \multicolumn{2}{|c|}{ SO $_{\mathbf{x}}$} \\
\hline & $\begin{array}{l}\text { Por } \mathrm{m}^{3} \text { de } \\
\text { vinhaça } \\
(\mathrm{kg})\end{array}$ & $\underset{\text { (t) }}{\text { Anual }}$ & $\begin{array}{c}\text { Por } \mathrm{m}^{3} \text { de } \\
\text { vinhaça } \\
(\mathrm{kg})\end{array}$ & $\underset{(t)}{\text { Anual }}$ & $\begin{array}{c}\text { Por } \mathrm{m}^{3} \text { de } \\
\text { vinhaça } \\
(\mathrm{kg})\end{array}$ & $\underset{(t)}{\text { Anual }}$ \\
\hline Lagoas e canais & 13,80 & 13.250 & 0,00 & 0,00 & 0,00 & 0,00 \\
\hline Motores diesel & 0,39 & 370,56 & 3,30 & 3,17 & 0,11 & 0,11 \\
\hline Eletricidade & 0,05 & 48,96 & 0,06 & 0,05 & 0,02 & 0,23 \\
\hline TOTAL & 14,24 & $13.669,52$ & 3,36 & 3,18 & 0,13 & 0,34 \\
\hline
\end{tabular}

Fonte: Autor.

\subsubsection{Cenário 2: Biodigestão anaeróbia com geração de eletricidade}

Devido ao sistema de distribuição da vinhaça ser o mesmo do cenário de referência, tem-se a mesma emissão de $\mathrm{NO}_{\mathrm{x}}$ e $\mathrm{SO}_{\mathrm{x}}$ nos motores diesel. Esta emissão precisa ser incrementada com a emissão do motogerador a biogás, que é calculada a seguir. Utilizando um fator de emissão de $\mathrm{NO}_{\mathrm{x}}$ para motogeradores a biogás, pode ser calculada a emissão anual deste poluente (Equação 50).

$$
\mathrm{NO}_{\mathrm{x} / \mathrm{ano}}=\mathrm{Q}_{\text {biogás/ano }} \times \mathrm{F}_{\mathrm{NOx}}
$$

Equação 50

Onde:

\begin{tabular}{|c|c|c|c|}
\hline \multicolumn{4}{|c|}{ Dados de entrada } \\
\hline Símbolo & Significado & Valor & Fonte \\
\hline$Q_{\text {biogás/ano }}$ & Energia térmica produzida com biogás por ano & $97 \mathrm{TJ} / \mathrm{ano}$ & Equação 20 \\
\hline $\mathrm{F}_{\mathrm{NOx}}$ & Fator de emissão de NOx do motogerador a biogás & $232,16 \mathrm{kgNOx} / \mathrm{TJ}$ & CEC, 2009 \\
\hline \multicolumn{4}{|c|}{ Resultados } \\
\hline $\mathrm{NO}_{\mathrm{x} / \mathrm{ano}}$ & Emissão de $\mathrm{NO}_{2}$ por ano no motogerador a biogás & $22,52 \mathrm{tNO}_{\mathrm{x}} /$ ano & Equação 50 \\
\hline
\end{tabular}

Portanto, a emissão do motogerador é mais significativa que a produzida na frota de $4,87 \mathrm{tNO}_{\mathrm{x}} / \mathrm{ano}$. 
No que diz respeito ao $\mathrm{SO}_{\mathrm{x}}$, supõe-se que todo o enxofre presente no biogás se oxida no motor $^{37}$, pois esta reação se produz em taxas elevadas com este tipo de equipamento. Sabendo que o biogás contém $75 \mathrm{ppm}$ de $\mathrm{H}_{2} \mathrm{~S}^{38}$ na entrada (saída do dessulfurificador), podese calcular a emissão de $\mathrm{SO}_{\mathrm{x}}$.

$$
\mathrm{SO}_{\mathrm{x} / \mathrm{ano}}=\mathrm{V}_{\text {biogás/ano }} \times\left(1-\mathrm{V}_{\% \mathrm{vaz}}\right) \times\left[\mathrm{H}_{2} \mathrm{~S}\right] \times \frac{\mathrm{M}_{\mathrm{SO} 2}}{\mathrm{M}_{\mathrm{H} 2 \mathrm{~S}}} \quad \text { Equação } 51
$$

Onde:

\begin{tabular}{llll}
\hline & \multicolumn{2}{c}{ Dados de entrada } & \\
Símbolo & Significado & Valor & Fonte \\
$\mathrm{V}_{\text {biogás/ano }}$ & Volume de biogás produzido por ano & $5.745 .000 \mathrm{Nm}^{3} /$ ano & Equação 19 \\
$\mathrm{V}_{\% \text { vaz }}$ & Porcentagem de volume de biogás vazado & $5 \%$ & \\
{$\left[\mathrm{H}_{2} \mathrm{~S}\right]$} & Concentração de $\mathrm{H}_{2} \mathrm{~S}$ no biogás & $113 \mathrm{mg} / \mathrm{m}^{39}$ & PAQUES, 2014 \\
$\mathrm{M}_{\mathrm{H} 2 \mathrm{~S}}$ & Massa molecular do $\mathrm{H}_{2} \mathrm{~S}$ & $34,08 \mathrm{~g} / \mathrm{M}$ & \\
$\mathrm{M}_{\mathrm{SO} 2}$ & Massa molecular do $\mathrm{SO}_{2} \quad$ Resultados & $64,06 \mathrm{~g} / \mathrm{M}$ & \\
& & & \\
$\mathrm{SO}_{2 / \text { ano }}$ & Emissão de $\mathrm{SO}_{2}$ por ano no motogerador a biogás & $1,6 \mathrm{tSO}_{2} /$ ano & Equação 51 \\
\hline
\end{tabular}

Emissão de $\mathrm{NO}_{x}$ e $\mathrm{SO}_{x}$ evitada por produção de energia elétrica no Cenário 2:

Utilizando os dados da Tabela 28 e o valor da produção de eletricidade com o motogerador a biogás, podem ser calculadas as emissões evitadas de $\mathrm{NO}_{\mathrm{x}}$ e $\mathrm{SO}_{\mathrm{x}}$. A Tabela 30 resume os resultados para o Cenário 2.

Tabela 30. Emissões gasosas no Cenário 2

\begin{tabular}{|c|c|c|c|c|c|c|}
\hline \multirow[b]{2}{*}{ Fonte } & \multicolumn{2}{|c|}{$\mathrm{CO}_{2} \mathrm{eq}$} & \multicolumn{2}{|c|}{$\mathbf{N O}_{\mathbf{x}}$} & \multicolumn{2}{|c|}{$\mathbf{S O}_{\mathbf{x}}$} \\
\hline & $\begin{array}{l}\text { Por } \mathbf{m}^{3} \text { de } \\
\text { vinhaça } \\
(\mathrm{kg})\end{array}$ & $\begin{array}{c}\text { Anual } \\
(t)\end{array}$ & $\begin{array}{c}\text { Por } \mathbf{m}^{3} \text { de } \\
\text { vinhaça } \\
\text { (g) }\end{array}$ & $\begin{array}{c}\text { Anual } \\
(\mathbf{t})\end{array}$ & $\begin{array}{l}\text { Por } \mathbf{m}^{3} \text { de } \\
\text { vinhaça } \\
(\mathrm{g})\end{array}$ & $\begin{array}{c}\text { Anual } \\
(t)\end{array}$ \\
\hline Biodigestor & 2,27 & $2.177,28$ & 0,00 & 0,00 & 0,00 & 0,00 \\
\hline Motores diesel & 0,67 & 642,00 & 5,10 & 4,87 & 0,11 & 0,12 \\
\hline Motogerador & 0,00 & 0,00 & 23,46 & 22,52 & 1,67 & 1,60 \\
\hline Eletricidade & $-0,56$ & $-541,44$ & $-0,61$ & $-0,59$ & $-2,63$ & $-2,53$ \\
\hline TOTAL & 2,43 & $2.277,84$ & 27,95 & 26,80 & $-0,85$ & $-0,81$ \\
\hline
\end{tabular}

Fonte: Autor.

\subsubsection{Cenário 3: Incineração com geração de eletricidade}

No referente às emissões de $\mathrm{NO}_{\mathrm{x}}$, o fabricante de queimadores garante que o nível das emissões de $\mathrm{NO}_{\mathrm{x}}$ pode ser reduzido até $200 \mathrm{mg} / \mathrm{Nm}^{3}$ nos gases de exaustão, com uma adequada operação da caldeira (SAACKE, 2014). Assim, deve ser estimada a vazão total de

\footnotetext{
${ }^{37}$ No motor pode se dar a seguinte reação de oxidação: $2 \mathrm{H}_{2} \mathrm{~S}+3 \mathrm{O}_{2}=2 \mathrm{SO}_{2}+2 \mathrm{H}_{2} \mathrm{O}$

${ }^{38}$ Valor da saída de $\mathrm{H}_{2} \mathrm{~S}$ do dessulfurizador (PAQUES, 2014).

$3975 \mathrm{ppm}$ de $\mathrm{H}_{2} \mathrm{~S}$ é equivalente a $113 \mathrm{mgH}_{2} \mathrm{~S} / \mathrm{m}^{3}$ de biogás.
} 
gases produzidos pela queima da vinhaça concentrada na caldeira. Este cálculo, detalhado no Anexo A, é baseado na composição da vinhaça concentrada e do gás natural.

Considerando o volume total de gases de exaustão e a proporção de $\mathrm{NO}_{\mathrm{x}}$ dada pelo fabricante, pode-se estimar a emissão deste poluente. Os resultados dos cálculos do Anexo A aparecem na Tabela 31. Para o cálculo da emissão do $\mathrm{SO}_{\mathrm{x}}$, considera-se que todo o enxofre presente na vinhaça é oxidado durante a combustão.

Tabela 31. Emissão de $\mathrm{NO}_{x}$ e $\mathrm{SO}_{x}$ do incinerador de vinhaça.

\begin{tabular}{|c|c|c|c|c|c|}
\hline Poluente & $\begin{array}{c}\text { Emissão sem } \\
\text { tratamento por } \mathbf{m}^{3} \\
\text { vinhaça }(\mathrm{g})\end{array}$ & $\begin{array}{c}\text { Emissão com } \\
\text { tratamento por } \mathbf{m}^{3} \\
\text { vinhaça }(\mathrm{g})\end{array}$ & $\begin{array}{c}\text { Emissão específica } \\
\text { sem tratamento } \\
(\mathrm{g} / \mathrm{MWh})^{*}\end{array}$ & $\begin{array}{l}\text { Emissão específica } \\
\text { com tratamento } \\
(\mathrm{g} / \mathrm{MWh})^{*}\end{array}$ & $\begin{array}{c}\text { Emissão específica } \\
\text { termoelétrica no } \\
\text { Brasil (g/MWh)* }\end{array}$ \\
\hline $\mathrm{NO}_{\mathrm{x}}$ & 42,94 & 2,15 & $3.816,67$ & 190,83 & 89,29 \\
\hline $\mathrm{SO}_{2}$ & $1.035,84$ & 51,75 & 92.075 & $4.603,75$ & 383,17 \\
\hline
\end{tabular}

Fonte de dados: Autor. *Cálculo utilizando $960.000 \mathrm{~m}^{3}$ de vinhaça/ano

A Tabela 31 mostra os valores de emissão com e sem tratamento dos gases da combustão da vinhaça. Sistemas como a dessulfurização por via úmida, que neutralizam o $\mathrm{SO}_{\mathrm{x}}$ por meio da injeção de reagentes básicos como magnésio, amônia ou calcários, e sistemas $\mathrm{DeNO}_{\mathrm{x}}$ tipo SCR-Selective Catalyst Reduction, são altamente eficientes abatendo mais do 95\% das emissões. Neste trabalho, contempla-se a implementação de um sistema de dessulfurização do gás de exaustão. Apesar da instalação da limpeza de gases, as emissões continuam sendo elevadas devido, fundamentalmente, à vinhaça possuir grande quantidade de enxofre e nitrogênio. Ainda assim, existem condições técnicas para o cumprimento da Resolução CONAMA 382/06 onde foram estabelecidos limites de emissão para fontes fixas (CONAMA, 2006).

Emissão de $\mathrm{NO}_{x}$ e $\mathrm{SO}_{x}$ evitada por produção de energia elétrica no Cenário 3:

Para calcular as emissões evitadas de $\mathrm{NO}_{\mathrm{x}}$ e $\mathrm{SO}_{\mathrm{x}}$ pela geração de eletricidade, são utilizados os dados da Tabela 28 os da produção de eletricidade com o sistema de cogeração alimentado com vinhaça concentrada e com gás natural. $\mathrm{O}$ resumo dos resultados aparece na Tabela 32.

Tabela 32. Emissões gasosas no Cenário 3.

\begin{tabular}{|c|c|c|c|c|c|c|}
\hline \multirow[b]{2}{*}{ Fonte } & \multicolumn{2}{|c|}{$\mathrm{CO}_{2} \mathrm{eq}$} & \multicolumn{2}{|c|}{$\mathbf{N O}_{\mathbf{x}}$} & \multicolumn{2}{|c|}{$\mathbf{S O}_{\mathbf{x}}$} \\
\hline & $\begin{array}{c}\text { Por } \mathbf{m}^{3} \text { de } \\
\text { vinhaça (kg) }\end{array}$ & $\begin{array}{c}\text { Anual } \\
(t)\end{array}$ & $\begin{array}{c}\text { Por } \mathbf{m}^{3} \text { de } \\
\text { vinhaça }(\mathrm{g})\end{array}$ & $\underset{(t)}{\text { Anual }}$ & $\begin{array}{c}\text { Por }^{3} \text { de } \\
\text { vinhaça }(g)\end{array}$ & $\underset{(t)}{\text { Anual }}$ \\
\hline Incinerador & 2,85 & $2.736,00$ & 42,94 & 41,22 & 51,75 & 49,68 \\
\hline Eletricidade & $-0,92$ & $-883,20$ & $-1,00$ & $-0,96$ & $-4,31$ & $-4,14$ \\
\hline TOTAL & 1,93 & 1852,80 & 41,94 & 40,26 & 47,44 & 45,54 \\
\hline
\end{tabular}

Fonte: Autor. 


\subsubsection{Cenário 4: Biodigestão com concentração e uso veicular}

Igualmente ao que foi feito anteriormente para o $\mathrm{CO}_{2}$, para o cálculo das emissões de $\mathrm{NO}_{\mathrm{x}}$ e $\mathrm{SO}_{\mathrm{x}}$, considerado que uma parte da frota da usina com motores diesel será transformada para uso de gás. Portanto, as emissões do diesel serão em parte evitadas, mas deverão ser contabilizadas as emissões dos motores que funcionam com biometano.

Quando se considera o ciclo de vida completo dos combustíveis, a redução de emissão de $\mathrm{NO}_{\mathrm{x}}$ chega a $40 \%$ com a introdução de motores GNV, segundo um estudo da Argonne National Labs (2000). Este último estudo citado comparava diesel com gás natural, em consequência o beneficio utilizando biogás pode ser ainda maior por ser um combustível produzido na própria usina, evitando a necessidade de seu transporte. Baseado nesta porcentagem de redução e utilizando a produção de diesel equivalente obtida com biometano, calcula-se a emissão de $\mathrm{NO}_{\mathrm{x}}$ do Cenário 4.

Para estimar a emissão de $\mathrm{SO}_{\mathrm{x}}$, considera-se que, por um lado, se evita a queima do enxofre do diesel. Por outro lado, será emitido o enxofre remanescente na forma de $\mathrm{H}_{2} \mathrm{~S}$ contido no biogás depois da dessulfurização. Com os valores da quantidade de enxofre, presente no diesel e no biogás, e supondo que todo o enxofre destes combustíveis se oxida no motor, pode ser calculada a emissão de $\mathrm{SO}_{\mathrm{x}}$ do Cenário 4. Os resultados deste cálculo se encontram resumidos na Tabela 33 .

Tabela 33. Emissões gasosas no Cenário 4.

\begin{tabular}{|c|c|c|c|c|c|c|}
\hline \multirow[b]{2}{*}{ Fonte } & \multicolumn{2}{|c|}{$\mathrm{CO}_{2} \mathrm{eq}$} & \multicolumn{2}{|c|}{$\mathrm{NO}_{\mathrm{x}}$} & \multicolumn{2}{|c|}{$\mathbf{S O}_{\mathbf{x}}$} \\
\hline & $\begin{array}{c}\text { Por } \mathrm{m}^{3} \text { de } \\
\text { vinhaça } \\
(\mathrm{kg})\end{array}$ & $\begin{array}{c}\text { Anual } \\
\text { (t) }\end{array}$ & $\begin{array}{c}\text { Por m }^{3} \text { de } \\
\text { vinhaça } \\
\text { (g) }\end{array}$ & $\underset{(t)}{\text { Anual }}$ & $\begin{array}{c}\text { Por } \mathrm{m}^{3} \text { de } \\
\text { vinhaça } \\
(\mathrm{g})\end{array}$ & $\underset{(t)}{\text { Anual }}$ \\
\hline Biodigestor & 2,27 & $2.177,28$ & 0,00 & 0,00 & 0,00 & 0,00 \\
\hline Motores diesel & $-4,54$ & $-4.353,60$ & $-38,92$ & $-37,36$ & 1,30 & 1,25 \\
\hline Motores biogás & 0,00 & 0,00 & 23,35 & 22,42 & 1,67 & 1,60 \\
\hline Total & $-2,267$ & $-2176,32$ & $-15,57$ & $-14,94$ & 2,97 & 2,85 \\
\hline
\end{tabular}

Fonte: Autor.

\subsection{Resultados da avaliação de impacto ambiental dos cenários considerados}

\subsubsection{Solo e água}

A seguir, são resumidos os principais impactos sobre o solo e sobre a água encontrados em cada cenário realizando uma comparação com o Cenário 0 de referência. 
Tabela 34. Potenciais impactos dos Cenários sobre o solo e a água.

\begin{tabular}{|c|c|c|c|c|}
\hline Impacto & 1. Concentração & $\begin{array}{l}\text { 2. Biodigestão + } \\
\text { Eletricidade }\end{array}$ & $\begin{array}{l}\text { 3. Incineração + } \\
\text { Eletricidade }\end{array}$ & $\begin{array}{c}\text { Biodigestão + } \\
\text { Concentração + Uso } \\
\text { Veicular }\end{array}$ \\
\hline $\begin{array}{l}\text { Salinização do solo } \\
\text { e água (nitratos e } \\
\text { potássio) }\end{array}$ & $\begin{array}{l}\text { Facilita a dispersão dos } \\
\text { sais. }\end{array}$ & $\begin{array}{l}\text { Permanece o problema do } \\
\text { transporte dos sais a } \\
\text { longas distâncias. }\end{array}$ & $\begin{array}{l}\text { Elimina totalmente o } \\
\text { problema da dispersão } \\
\text { dos sais. }\end{array}$ & $\begin{array}{l}\text { Facilita a dispersão dos } \\
\text { sais. }\end{array}$ \\
\hline $\begin{array}{l}\text { Aumento da matéria } \\
\text { orgânica no solo }\end{array}$ & $\begin{array}{l}\text { Semelhante aumento da } \\
\text { matéria orgânica no solo. }\end{array}$ & $\begin{array}{l}\text { Menor quantidade de } \\
\text { matéria orgânica } \\
\text { incorporada ao solo. }\end{array}$ & $\begin{array}{l}\text { Elimina totalmente o } \\
\text { aumento, por incinerar a } \\
\text { matéria orgânica. }\end{array}$ & $\begin{array}{l}\text { Menor quantidade de } \\
\text { matéria orgânica } \\
\text { incorporada ao solo. }\end{array}$ \\
\hline $\begin{array}{l}\text { Alteração do pH do } \\
\text { solo. }\end{array}$ & $\begin{array}{l}\text { Igual à fertirrigação in } \\
\text { natura, existe uma } \\
\text { redução inicial do } \mathrm{pH} \mathrm{e} \\
\text { posterior elevação. }\end{array}$ & $\begin{array}{l}\text { Não existe uma redução } \\
\text { inicial do } \mathrm{pH} \text {. }\end{array}$ & $\begin{array}{l}\text { Não existe nenhuma } \\
\text { alteração no } \mathrm{pH} \text {. }\end{array}$ & $\begin{array}{l}\text { Não existe uma redução } \\
\text { inicial do } \mathrm{pH} \text {. }\end{array}$ \\
\hline $\begin{array}{l}\text { Redução de uso de } \\
\text { fertilizantes de } \\
\text { origem mineral. }\end{array}$ & $\begin{array}{l}\text { Melhora da eficiência da } \\
\text { fertirrigação por evitar } \\
\text { vazamentos em lagoas e } \\
\text { canais. }\end{array}$ & $\begin{array}{l}\text { Melhora das } \\
\text { características } \\
\text { fertilizantes, pelo } \\
\text { nitrogênio }\left(\mathrm{NH}^{+4}\right) \text { estar } \\
\text { mais disponível à planta. }\end{array}$ & $\begin{array}{l}\text { Melhora da eficiência da } \\
\text { fertirrigação por evitar } \\
\text { vazamentos em lagoas e } \\
\text { canais. }\end{array}$ & $\begin{array}{l}\text { Melhora da eficiência da } \\
\text { fertirrigação e das } \\
\text { características do } \\
\text { fertilizante. (Soma de } \\
\text { vantagens Cenário } 1 \text { e 2) }\end{array}$ \\
\hline $\begin{array}{l}\text { Alteração da } \\
\text { população } \\
\text { microbiana. }\end{array}$ & $\begin{array}{l}\text { Semelhante à fertirrigação } \\
\text { in natura, favorecendo o } \\
\text { desenvolvimento. }\end{array}$ & $\begin{array}{l}\text { Evita a dispersão de } \\
\text { antibióticos ativos no } \\
\text { meio, por ser } \\
\text { incompatível com a } \\
\text { biodigestão. }\end{array}$ & $\begin{array}{l}\text { Evita a dispersão de } \\
\text { antibióticos no meio. }\end{array}$ & $\begin{array}{l}\text { Evita a dispersão de } \\
\text { antibióticos ativos no } \\
\text { meio por ser incompatível } \\
\text { com a biodigestão. }\end{array}$ \\
\hline $\begin{array}{l}\text { Compactação do } \\
\text { solo }\end{array}$ & $\begin{array}{l}\text { Possível aumento da } \\
\text { compactação do solo nas } \\
\text { áreas com aplicação } \\
\text { direta. }\end{array}$ & $\begin{array}{l}\text { Igual ao cenário de } \\
\text { referência. }\end{array}$ & $\begin{array}{l}\text { Evita totalmente o trânsito } \\
\text { para fertirrigação dentro } \\
\text { do canavial. }\end{array}$ & $\begin{array}{l}\text { Possível aumento da } \\
\text { compactação do solo nas } \\
\text { áreas com aplicação } \\
\text { direta. }\end{array}$ \\
\hline $\begin{array}{l}\text { Movimento de } \\
\text { terras }\end{array}$ & $\begin{array}{l}\text { Menor ao cenário de } \\
\text { referência. }\end{array}$ & $\begin{array}{l}\text { Igual ao cenário de } \\
\text { referência. }\end{array}$ & $\begin{array}{l}\text { Evita a construção de } \\
\text { lagoas e canais. }\end{array}$ & $\begin{array}{l}\text { Menor ao cenário de } \\
\text { referência. }\end{array}$ \\
\hline $\begin{array}{l}\text { Aproveitamento da } \\
\text { água. }\end{array}$ & $\begin{array}{l}\text { Possibilita parcialmente o } \\
\text { uso da água da vinhaça. }\end{array}$ & $\begin{array}{l}\text { Não possibilita uso da } \\
\text { água da vinhaça. }\end{array}$ & $\begin{array}{l}\text { Possibilita utilizar quase a } \\
\text { totalidade da água da } \\
\text { vinhaça. }\end{array}$ & $\begin{array}{l}\text { Possibilita parcialmente o } \\
\text { uso da água da vinhaça. }\end{array}$ \\
\hline
\end{tabular}

Fonte: Autor a partir dos resultados obtidos durante a revisão bibliográfica.

Como pode ser observado na Tabela 34, a incineração é o sistema que mais reduz os impactos negativos sobre o solo e a água, por eliminar totalmente o volume de vinhaça e os impactos atrelados à sua distribuição. Também, este sistema permite uma maior quantidade de uso da água na usina proveniente da vinhaça. Este sistema permite, também, maior quantidade de água proveniente da vinhaça para reúso na usina. Por outro lado, esta água pode ser fundamental em circunstancias de seca como irrigação de salvamento.

Um cenário interessante é o que combina a biodigestão com a concentração, por reunir as vantagens do tratamento biológico do efluente e com a redução do volume e a recuperação parcial da água a partir do processo de concentração.

\subsubsection{Emissões de GEEs, $\mathrm{NO}_{x}$ e SO}

Os resultados obtidos nos balanços das emissões atmosféricas nos diferentes cenários estão resumidos na Tabela 35. 
Tabela 35. Emissões atmosféricas associadas aos Cenários.

\begin{tabular}{|c|c|c|c|c|c|c|}
\hline \multirow[b]{2}{*}{ Cenário } & \multicolumn{2}{|c|}{$\mathrm{CO}_{2} \mathrm{eq}$} & \multicolumn{2}{|c|}{ NO $_{x}$} & \multicolumn{2}{|c|}{$\mathbf{S O}_{\mathbf{x}}$} \\
\hline & $\begin{array}{c}\text { Por } \mathbf{m}^{3} \text { de } \\
\text { vinhaça } \\
\text { (kg) }\end{array}$ & $\begin{array}{c}\text { Anual } \\
(\mathrm{t})\end{array}$ & $\begin{array}{l}\text { Por } \mathbf{m}^{3} \text { de } \\
\text { vinhaça } \\
\text { (g) }\end{array}$ & $\begin{array}{c}\text { Anual } \\
(\mathbf{t})\end{array}$ & $\begin{array}{c}\text { Por } \mathbf{m}^{3} \text { de } \\
\text { vinhaça } \\
\text { (g) }\end{array}$ & $\underset{(t)}{\text { Anual }}$ \\
\hline 0 & 20,11 & $19.342,00$ & 5,10 & 4,87 & 0,19 & 0,18 \\
\hline 1 & 14,24 & $13.669,52$ & 3,30 & 3,18 & 0,13 & 0,34 \\
\hline 2 & 2,43 & $2.277,84$ & 27,95 & 26,80 & $-0,85$ & $-0,81$ \\
\hline 3 & 1,93 & 1852,80 & 41,94 & 40,26 & 47,44 & 45,54 \\
\hline 4 & $-2,267$ & $-2176,32$ & $-15,57$ & $-14,94$ & 2,97 & 2,85 \\
\hline
\end{tabular}

Fonte: Autor.

A emissão de GEEs mostrada na Tabela 35 é representada na Figura 34.

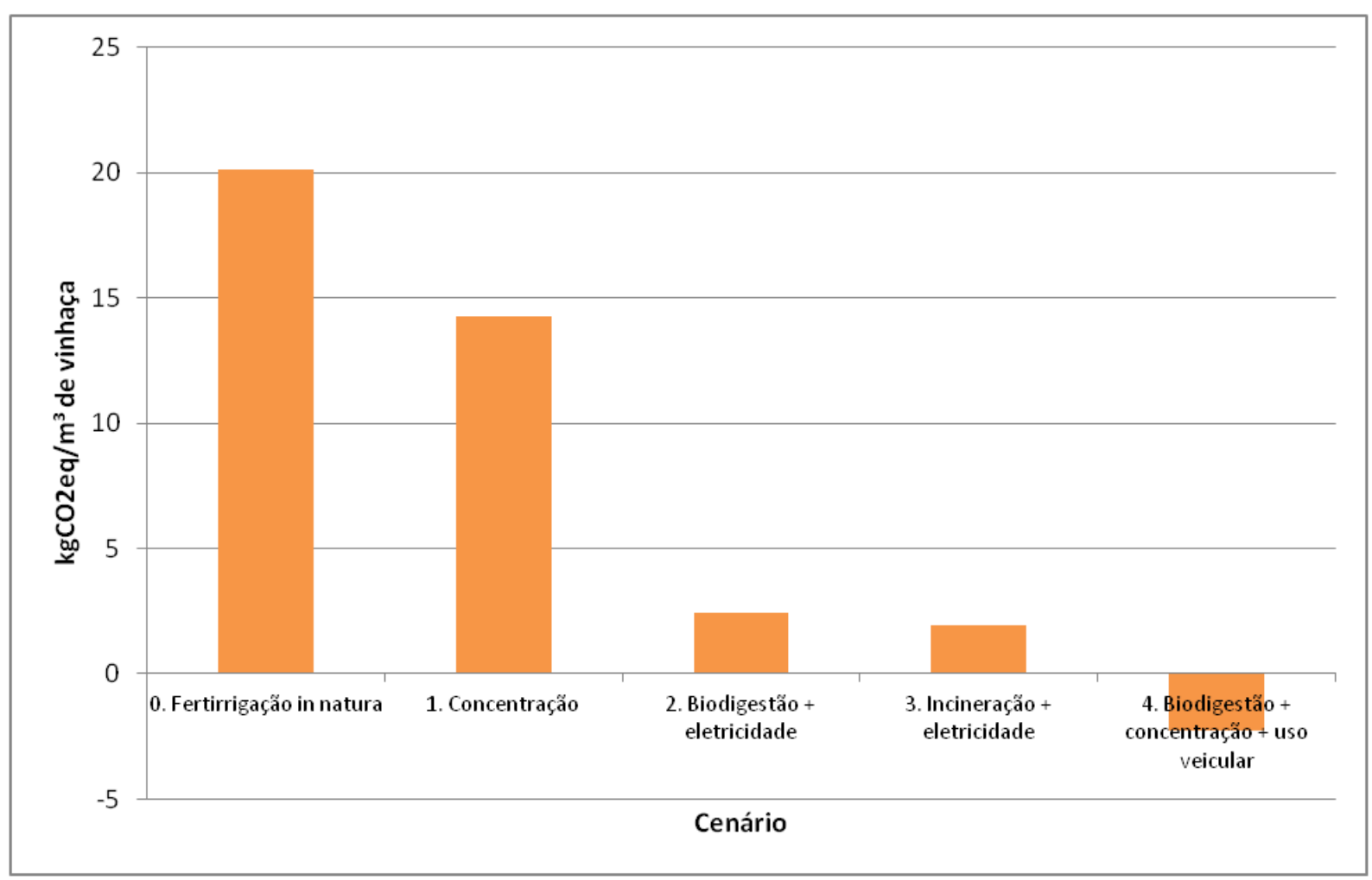

Figura 34. Balanço de emissões de GEEs dos cenários.

Fonte: autor.

Observa-se que o Cenário 4 é o mais vantajoso em termos de emissões calculadas de GEEs, pois este chega a ter um balanço negativo de emissões com respeito ao cenário de referência. Nos cenários com produção de eletricidade, a biodigestão e incineração tem um desempenho semelhante na redução de emissões de GEEs, sendo esta muito significativa. No Cenário 2, a redução de emissões é proporcional à porcentagem de volume de vinhaça concentrado. 
A Figura 35 mostra as emissões produzidas e evitadas em cada cenário diferenciando sua fonte.

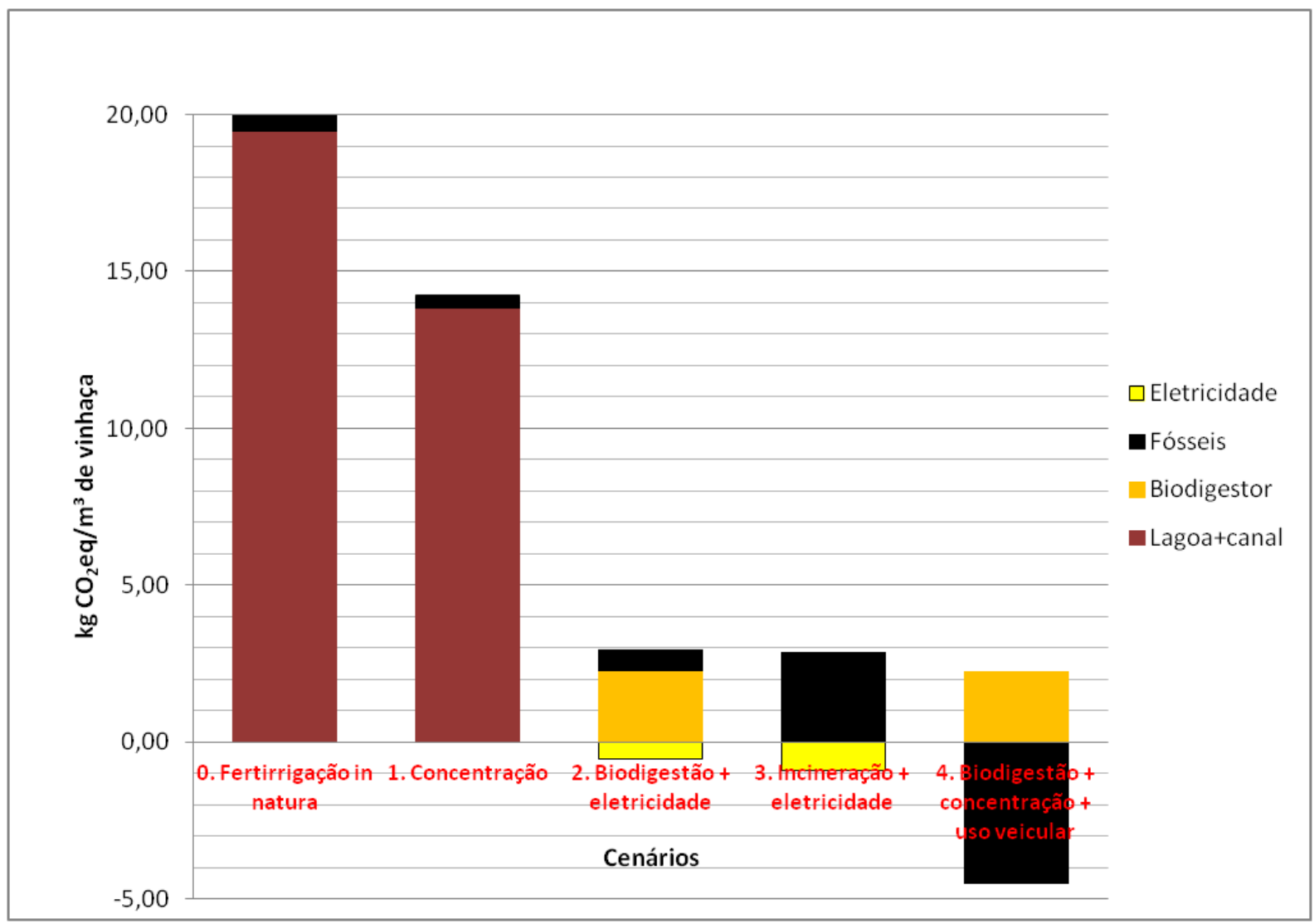

Figura 35. Emissões por fonte nos diferentes cenários.

Fonte: Autor.

No Cenário 1 destacam as emissões produzidas em lagoas de armazenamento e canais. Este resultado pode apresentar ampla variação, pois as emissões de $\mathrm{CH}_{4}$ em lagoas e canais dependem em grande parte das dimensões, da geometria e do revestimento destas estruturas (Paredes, 2011), assim como do teor de matéria orgânica da vinhaça que varia ao longo da safra. Também, este resultado pode ser influenciado pela porcentagem de vinhaça que é transportada em caminhão.

A implantação de concentradores no Cenário 1 não produz uma redução importante do GEEs, visto que é concentrado somente o volume transportado em caminhões. A redução no consumo de diesel é significativa, porém, com relação às emissões, continua ocorrendo a produção de $\mathrm{CH}_{4}$ em lagoas e canais.

No Cenário 3, a remoção da fração da matéria orgânica que pode ser degradada biologicamente, reduz expressivamente as emissões de $\mathrm{CH}_{4}$, mostrando a importância da implementação da biodigestão como método para a redução de GEEs no setor 
sucroalcooleiro. Por outro lado, a eletricidade produzida a partir do biogás capturado não tem um impacto importante na mitigação, devido à magnitude de seu potencial de geração e ao fato de que o 76,9\% da matriz no Brasil é hidroelétrica (BEN, 2013), fazendo com que a ICGEB seja de apenas $82 \mathrm{kgCO} 2 \mathrm{eq} / \mathrm{MWh}$ (BEN, 2013).

O Cenário 3 obteve, também, uma importante mitigação de emissões com a incineração, uma vez que todo o carbono orgânico presente na vinhaça é convertido em $\mathrm{CO}_{2}$ mediante combustão, fechando o ciclo do carbono fixado previamente pela cana. A energia elétrica produzida pode chegar a ser o dobro da produzida no Cenário 2, entretanto, o Cenário 3 é o que apresenta mais consumo de combustíveis de origem fóssil, devido ao uso de gás natural na combustão, afetando o balanço energético do etanol.

O Cenário 4 é o de menor emissão e uso de combustíveis fósseis, o que melhora o balanço energético do etanol. A biodigestão retira a matéria orgânica, evitando as emissões do efluente destinado a fertirrigação. A concentração diminui o consumo de combustível e evita parcialmente a distribuição por canais. Contabilizando as emissões de GEEs, o uso do biogás como substituto do diesel é muito mais conveniente que seu emprego em geração de eletricidade, devido ao caráter pouco intensivo em carbono da matriz elétrica brasileira. A emissão de $\mathrm{NO}_{\mathrm{x}}$ e $\mathrm{SO}_{\mathrm{x}}$ da Tabela 35 é representada na Figura 36.

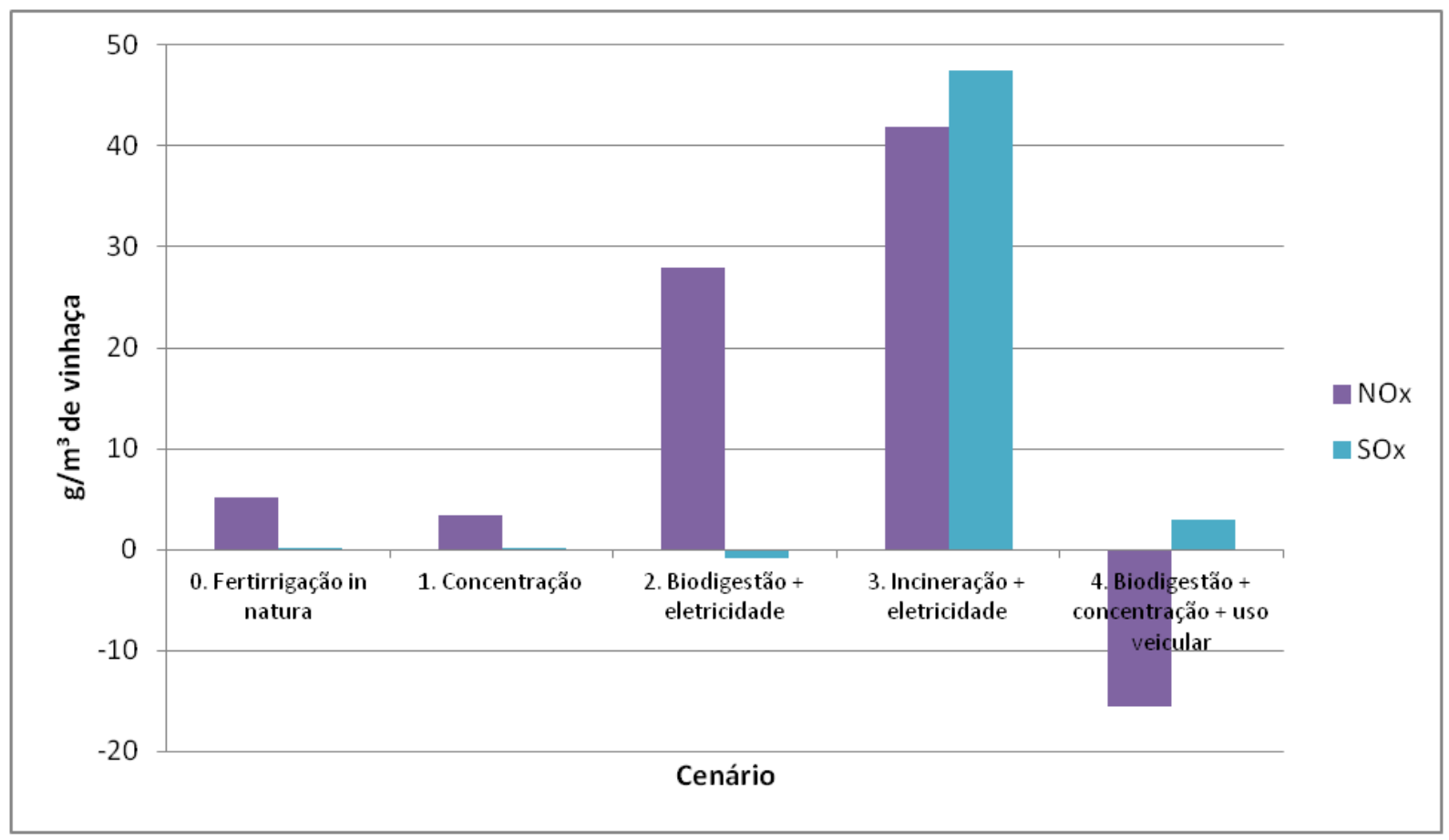

Figura 36. Balanço de emissões de $\mathrm{NO}_{\mathrm{x}}$ e $\mathrm{SO}_{\mathrm{x}}$ dos Cenários. Fonte: autor. 
As emissões de óxidos de nitrogênio e de enxofre são mais elevadas na incineração que nos demais cenários, existindo um significativo incremento delas com respeito ao cenário de referência. Estas emissões representadas na Figura 36, incluem um lavador de gases para o $\mathrm{SO}_{\mathrm{x}}$ mas não um sistema $\mathrm{DeNO}_{\mathrm{x}}$. Com a instalação do Cenário 2, de geração de eletricidade por meio de motor a biogás, o incremento de emissões também é considerável. O cenário com maior redução de emissões de $\mathrm{NO}_{\mathrm{x}}$ é o Cenário 4, onde se produz um balanço negativo dessas emissões.

Estes resultados são discutidos com maior detalhe no Capítulo 6. Ainda, no Capítulo 5, são utilizados os valores de redução de emissões de GEEs para avaliar o impacto que a valorização econômica dos serviços ambientais poderia ter sobre a viabilização econômica dos distintos tratamentos. 


\section{CAPÍTULO 5. AVALIAÇÃO ECONÔMICA}

Neste capítulo será avaliada a viabilidade econômica dos distintos cenários, tendo em vista o custo da fertirrigação, os custos de instalação, de operação e manutenção das diferentes tecnologias alternativas, o preço de venda da energia elétrica, assim como do diesel e do gás natural. Desta forma, pretende-se responder se o processamento da vinhaça com aproveitamento energético é um investimento atrativo nas condições atuais. No caso de resposta negativa, será feita uma análise incluindo a mitigação de impactos ambientais tais como o consumo de água e as emissões de GEEs, com o intuito de observar como afetaria a bonificação desta redução na viabilidade econômica dos cenários. Finalmente, em cada caso será determinado o preço que deveria ter a energia e qual seria o pagamento pela redução de impactos que fariam os investimentos serem interessantes para o setor.

Os indicadores calculados para a avaliação econômica de cada cenário são o Valor Presente Líquido (VLP), o PayBack descontado e a Taxa Interna de Retorno (TIR). Para o cálculo destes indicadores é necessária a elaboração do fluxo de caixa ${ }^{40}$ das tecnologias propostas no estudo. O objetivo principal dos indicadores econômicos, resumidos a seguir, é auxiliar na decisão de alocação de recursos financeiros a uma determinada tecnologia.

a) Valor Presente Líquido (VPL): O valor presente líquido relaciona o custo inicial de investimento $\left(\mathrm{FC}_{0}\right)$ de um projeto com seus fluxos de caixa futuros $\left(\mathrm{FC}_{\mathrm{j}}\right)$, sendo esses últimos descontados por uma taxa (taxa de juros). Quando o VPL > 0 é um indicativo de que o investimento no projeto poderá dar rentabilidade ao investidor, sendo a quantia do lucro o próprio VPL em valores absolutos.

$$
\mathrm{VPL}=\sum_{j=1}^{n} \frac{\mathrm{FC}_{\mathrm{j}}}{(1-i)^{j}}-\mathrm{FC}_{0}
$$

Onde:

\begin{tabular}{lll}
\hline Símbolo & Significado & Dados de entrada \\
$\mathrm{FC}_{0}$ & Custo inicial de investimento & $\mathrm{R} \$$ \\
$\mathrm{FC}_{\mathrm{j}}$ & $\begin{array}{l}\text { Entradas (receitas) e saídas (custos) previsto para } \\
\text { cada período futuro }\end{array}$ & $\mathrm{R} \$$ \\
$\mathrm{i}$ & Taxa de juros ou taxa de desconto & $\%$ \\
$\mathrm{j}$ & Período de tempo & anos \\
$\mathrm{n}$ & Vida útil do projeto $\quad$ Resultado & anos \\
& \multicolumn{2}{c}{$\mathrm{R} \$$} \\
\hline
\end{tabular}

${ }^{40} \mathrm{O}$ fluxo de caixa resume as entradas (receitas) e saídas (custos) de capital ao longo da vida útil de um projeto. 
b) Payback descontado: É o período de tempo necessário para recuperar o investimento inicial de um projeto, a partir do fluxo de caixa descontado por uma taxa.

c) Taxa Interna de Retorno (TIR): Taxa de desconto (juros) que torna o Valor Presente Líquido do investimento igual a zero.

Os resultados oferecidos com o cálculo destes indicadores estão sujeitos a variações futuras uma vez que existem consideráveis incertezas, tais como a variação nos preços da energia, dos insumos e das taxas cambiais.

Para o cálculo dos indicadores foi utilizada uma taxa de desconto de $15 \%$, considerando que a Taxa SELIC ${ }^{41}$ em 12/2014 tinha um valor de $11,65 \%$ ao ano ${ }^{42}$, possibilitando, assim, uma margem de mais de 3\% para as flutuações futuras desta taxa, para a porcentagem de lucro do banco prestamista e para a inflação contra a rentabilidade do projeto.

Também, o valor adotado para a vida útil do projeto foi de 18 anos, sendo que, após esse período, os equipamentos não teriam valor residual.

O levantamento do preço dos equipamentos, assim como seus custos de operação e manutenção, foi realizado mediante uma revisão bibliográfica e junto os seguintes fabricantes e fornecedores: Citrotec $\AA^{43}$, Dedini S/A Indústrias de Base $^{44}$, L\&M Engenharia ${ }^{45}$, SotreqCaterpillar ${ }^{46}$, Paques Environmental Technology Shanghai Co. $\operatorname{Ltd}^{47}, \mathrm{DMT}^{48}$, Saacke $^{49}$ e Brasmetano Ind. Com. Ltda. ${ }^{50}$.

\subsection{Cenário 0 de referência: Fertirrigação com vinhaça in natura}

Neste cenário de referência, não são considerados os custos de instalação dado que a fertirrigação já se encontra amplamente implantada atualmente nas usinas. No caso da construção de uma nova usina, este custo de instalação deveria ser incluído para poder

\footnotetext{
${ }^{41}$ A Taxa referencial do Sistema Especial de Liquidação e de Custódia (SELIC) é também conhecida como a taxa básica de juros da economia brasileira. É a menor taxa de juros do país e serve de referência nos empréstimos feitos entre os bancos e também nas aplicações realizadas por estas instituições bancárias em títulos públicos federais.

${ }^{42}$ Banco Central do Brasil. Histórico das taxas de juros. Disponível em http://www.bcb.gov.br/Pec/Copom/Port/taxaSelic.asp; acessado em 06/12/2014.

43 citrotec.com.br/

${ }^{44}$ codistil.com.br/

45 lmengenharia.com.br/

46 sotreq.com.br/

${ }^{47}$ br.paques.nl/

48 dirkse-milieutechniek.com

${ }^{49}$ saacke.com.br/

${ }^{50}$ brasmetano.com.br/
} 
comparar com os demais cenários. Portanto, neste caso, são contabilizados exclusivamente os custos de operação e manutenção.

Os custos da fertirrigação são enormemente variáveis, dependendo da localização da usina e lavoura, do volume de produção, assim como de fatores como o relevo e as técnicas utilizadas no transporte e na aplicação. No presente estudo é utilizado um custo para a fertirrigação de $\mathrm{R} \$ 4 / \mathrm{m}^{3}$ de vinhaça (JORNALCANA, 2007), sendo este considerado um valor médio no setor. Multiplicando este custo médio pela produção anual de vinhaça, obtém-se o custo da fertirrigação para a usina modelo (Equação 53):

$$
\text { Cost }_{\text {fertirrigação/ano }}=\mathrm{V}_{4^{\circ} \mathrm{Bx} / \text { ano }} \times \mathrm{P}_{\text {fertirrigação }} \quad \text { Equação } 53
$$

Onde:

\begin{tabular}{|c|c|c|c|}
\hline \multicolumn{4}{|c|}{ Dados de entrada } \\
\hline Símbolo & Significado & Valor & Fonte \\
\hline $\mathrm{V}_{4^{\circ} \mathrm{B} \times / \text { ano }}$ & Volume de vinhaça $4^{\circ} \mathrm{Bx}$ produzido por ano & $960.000 \mathrm{~m}^{3} /$ ano & Tabela 2 \\
\hline $\mathrm{P}_{\text {fertiririgação }}$ & Custo unitário de fertirrigação & $\mathrm{R} \$ 4 / \mathrm{m}^{3}$ & $\begin{array}{l}\text { (JORNALCANA, } \\
\text { 2007) }\end{array}$ \\
\hline \multicolumn{4}{|c|}{ Resultados } \\
\hline $\operatorname{Cost}_{\text {fertirrigacão }}$ & Custo anual da fertirrigação & $\mathrm{R} \$ 3.840 .000 / \mathrm{ano}$ & Equação 53 \\
\hline
\end{tabular}

Observa-se que, para uma usina de porte médio, o uso da vinhaça na fertirrigação pode custar aproximadamente $\mathrm{R} \$ 4.000 .000 / a n o$, podendo este valor ser superior em condições adversas de relevo, quando há necessidade da diminuição na dose por hectare em função da saturação por potássio ou se as lavouras se encontram fora do raio econômico da dispersão. Por esta razão, é necessário dar alternativas para o setor no tratamento da vinhaça.

\subsection{Cenário 1: Concentração evaporativa}

Foram levantados, a partir de consulta aos fabricantes os custos relativos à instalação, à operação e à manutenção dos concentradores evaporativos encontrados no mercado brasileiro. Com estas informações, são calculados os custos de um concentrador de $40 \mathrm{t} / \mathrm{h}$ de capacidade de evaporação (Tabela 36). Na operação, não é contabilizado o uso de vapor, uma vez que o calor residual da destilação é aproveitado, sendo isto determinante para a viabilidade econômica do empreendimento. Na operação destes condensadores é recomendada a limpeza semanal circulando $35 \mathrm{~m}^{3}$ de dissolução de soda cáustica de $0,5 \%$, incluindo o custo do consumo deste reagente na operação. Também, é recomendada a limpeza com hidrojateamento na entressafra. 
Tabela 36. Custos no Cenário 1.

\begin{tabular}{llll}
\hline & Preço unitário & Unidades & Total \\
\hline $\begin{array}{l}\text { Instalação } \\
\text { Concentrador }\end{array}$ & $\mathrm{R} \$ 80.000 /(\mathrm{t} / \mathrm{h})$ & $40 \mathrm{t} / \mathrm{h}$ & $\mathrm{R} \$ 3.200 .000$ \\
\hline $\begin{array}{l}\text { Operação } \\
\text { Energia elétrica }\end{array}$ & $\mathrm{R} \$ 202 / \mathrm{MWh}$ & $600 \mathrm{MWhe} / \mathrm{ano}$ & $\mathrm{R} \$ 121.470 / \mathrm{ano}$ \\
\cline { 2 - 4 } $\begin{array}{l}\text { Energia térmica } \\
\text { Soda Caustica }\end{array}$ & $\mathrm{R} \$ 0$ & 0 & $\mathrm{R} \$ 0 / \mathrm{ano}$ \\
\cline { 2 - 4 } $\begin{array}{l}\text { Manutenção } \\
\text { Hidrojateamento }\end{array}$ & $\mathrm{R} 800 / \mathrm{t}$ & $2 \mathrm{t} / \mathrm{semana}$ & $\mathrm{R} \$ 55.000 /$ ano \\
\hline Custo anual O\&M & $\mathrm{R} \$ 50.000$ & $1 / \mathrm{ano}$ & $\mathrm{R} \$ 50.000 / \mathrm{ano}$ \\
\hline
\end{tabular}

Fonte: Autor baseado em dados dos fabricantes de equipamentos.

Para suprir o consumo de energia elétrica do concentrador, considera-se o fornecimento pelo sistema de cogeração da usina, deixando de ser exportada esta energia para a rede. Como preço da eletricidade vendida pela usina é tomado o valor de $\mathrm{R} \$ 202,45 / \mathrm{MWh}$, preço médio para as térmicas de bagaço de cana no $20^{\circ}$ Leilão de Energia Nova ${ }^{51}$.

Considera-se que a diminuição do custo em fertirrigação é proporcional à redução de volume conseguida com a concentração. Dessa forma, no Cenário 1 o volume evaporado é de $226.000 \mathrm{~m}^{3}$ e visto que o custo médio da fertirrigação é aproximadamente de $\mathrm{R} \$ 4 / \mathrm{m}^{3}$, obtémse uma economia de R $\$ 904.000 / a n o$. Introduzindo esta diminuição do volume de vinhaça como ganho na operação e a correspondente redução no custo de referência para seu tratamento, o investimento neste Cenário 1 apresenta os valores e indicadores financeiros apresentados na Tabela 37.

Tabela 37. Indicadores financeiros do investimento no Cenário 1

\begin{tabular}{ll}
\hline Investimento inicial & $\mathrm{R} \$ 3.200 .000^{\mathrm{a}}$ \\
Custo anual O\&M & $\mathrm{R} \$ 226.470 / \mathrm{ano}^{\mathrm{a}}$ \\
Diminuição do custo em fertirrigação & $\mathrm{R} \$ 904.000 / \mathrm{ano}^{\mathrm{b}}$ \\
Vida útil & $18 \mathrm{anos}^{\mathrm{c}}$ \\
Taxa de desconto & $15 \%^{\mathrm{c}}$ \\
VPL & $\mathrm{R} \$ 951.880^{\mathrm{b}}$ \\
Payback Descontado & $9 \mathrm{anos}^{\mathrm{b}}$ \\
TIR & $21 \%^{\mathrm{b}}$ \\
\hline
\end{tabular}

Fonte: a) Tabela 36; b) Calculado pelo autor; c) Valores preestabelecidos no estudo.

\footnotetext{
${ }^{51}$ Realizado no 28/11/2014 (INSTITUTO ACENDE BRASIL, 2014)
} 
Nas condições atuais, observa-se a atratividade deste investimento, o que explica a expansão na implantação desta tecnologia acontecida no setor a partir de 2009. Ressalta-se a condição de que a energia térmica para a evaporação deve ser fornecida sem consumo adicional de vapor, aproveitando o calor residual das colunas de destilação, tal e como foi comprovado no estudo realizado por Silva (2012).

\subsection{Cenário 2: Biodigestão anaeróbia com geração de eletricidade}

Para estudar a viabilidade econômica da instalação do Cenário 2, foram levantados os custos relativos a um sistema de reatores IC, por ser esta a mais eficiente tecnologia disponível no mercado, com respeito à remoção de matéria orgânica e à produção de biogás, tal como foi visto no Capítulo 2. Também foram levantados os custos associados a um lavador biológico de gás, sendo este tipo de sistema de limpeza recomendado para a quantidade de $\mathrm{H}_{2} \mathrm{~S}$ presente no biogás, para a escala de produção manejada e para o tipo de uso final (FNR, 2010). Quanto à geração elétrica, esta é realizada através de motogeradores de combustão interna, devido a sua economia frente a outras tecnologias tais como as microturbinas (COELHO et al, 2006, e SALOMON, 2007). Assim, para um sistema de biodigestão com capacidade de tratar $4.000 \mathrm{~m}^{3} / \mathrm{dia}$ de vinhaça com $29 \mathrm{~kg} \mathrm{DQO} / \mathrm{m}^{3}$ e que possua uma produção de biogás de $1.000 \mathrm{~m}$ 3/h, os custos de biodigestão, de limpeza do biogás e de geração elétrica a partir do mesmo são os apresentado na Tabela 38.

Tabela 38. Custos no Cenário 2.

\begin{tabular}{llll}
\hline & Preço unitário & Unidades & Total \\
\hline $\begin{array}{llll}\text { Instalação } \\
\text { Biodigestor }\end{array}$ & $\mathrm{R} \$ 110 /(\mathrm{kg} \mathrm{DQO} / \mathrm{dia})$ & $116.000 \mathrm{~kg} \mathrm{DQO} / \mathrm{dia}$ & $\mathrm{R} \$ 12.760 .000$ \\
\cline { 2 - 4 } $\begin{array}{l}\text { Dessulfurificador } \\
\text { Motogerador }\end{array}$ & $\mathrm{R} \$ 1.330 /\left(\mathrm{m}^{3} / \mathrm{h}\right)$ & $1.000 \mathrm{~m} / \mathrm{h}$ & $\mathrm{R} \$ 1.330 .000$ \\
\cline { 2 - 4 } Custo total de instalação & $\mathrm{R} \$ 2.000 / \mathrm{kW}$ & $1.300 \mathrm{~kW}$ & $\mathrm{R} \$ 2.600 .000$ \\
\hline $\begin{array}{l}\text { Operação e Manutenção } \\
\begin{array}{l}\text { Biodigestor }+ \\
\text { dessulfurificador }\end{array}\end{array}$ & $\mathrm{R} \$ 0,018 \mathrm{~kg}$ de DQO & $27.840 .000 \mathrm{~kg}$ & $\mathrm{R} \$ 16.690 .000$ \\
Motogerador & $\mathrm{R} \$ 40,00 / \mathrm{MWh}$ & $\mathrm{DQO} / \mathrm{ano}$ & \\
\hline Custo anual O\&M & & $7.550,4 \mathrm{MWh} / \mathrm{ano}$ & $\mathrm{R} \$ 302.016 / \mathrm{ano}$ \\
\hline
\end{tabular}

Fonte: Autor baseado em dados dos fabricantes de equipamentos. 
Utilizando os valores da Tabela 38 e a quantidade de produção de energia elétrica calculada anteriormente, é aproximado o custo de geração do $M W h_{e}$ neste cenário. Este custo de produção é determinado procurando o valor que faça nulo o VPL do investimento.

Tabela 39. Indicadores financeiros do investimento no Cenário 2

\begin{tabular}{ll}
\hline Investimento inicial & $\mathrm{R} \$ 16.690 .000^{\mathrm{a}}$ \\
Custo anual O\&M & $\mathrm{R} \$ 803.136 / \mathrm{ano}^{\mathrm{a}}$ \\
Eletricidade vendida & $6,6 \mathrm{GWh} / \mathrm{ano}^{\mathrm{d}}$ \\
Vida útil & $18 \mathrm{anos}^{\mathrm{c}}$ \\
Taxa de desconto & $15 \%^{\mathrm{c}}$ \\
Custo de produção da eletricidade & $\mathrm{R} \$ 540 / \mathrm{MWh}^{\mathrm{b}}$ \\
\hline
\end{tabular}

Fonte: a) Tabela 38; b) Calculado pelo autor; c) Valores preestabelecidos no estudo; d) Equação 21.

Observa-se um alto custo de produção de energia elétrica no Cenário 2. Isto se deve aos valores conservadores de produção de biogás baseados na experiência do biodigestor da usina São Martinho. Na Tabela 40, calcula-se este preço de produção assumindo valores mais otimistas dados pelos fabricantes de equipamentos, aumentando a proporção de metano no biogás, o rendimento do gerador e a produção de biogás por cada $\mathrm{m}^{3}$ de vinhaça.

Tabela 40. Custo de produção da eletricidade gerada com biogás de vinhaça.

\begin{tabular}{|c|c|c|}
\hline & Conservador & Otimista \\
\hline \% metano no biogás & $50^{\mathrm{a}}$ & $65^{\mathrm{c}}$ \\
\hline Rendimento do motogerador & $0,29^{\mathrm{b}}$ & $0,35^{\mathrm{b}}$ \\
\hline $\mathbf{m}^{3}$ biogás / $\mathbf{m}^{3}$ vinhaça & $6^{\mathrm{a}}$ & $9^{c}$ \\
\hline Eletricidade produzida $/ \mathrm{m}^{3}$ vinhaça & $6,9 \mathrm{kWh}_{\mathrm{e}} / \mathrm{m}^{3 \mathrm{~d}}$ & $20,3 \mathrm{kWh}_{\mathrm{e}} / \mathrm{m}^{3 \mathrm{~d}}$ \\
\hline Potência instalada & $1,3 \mathrm{MW}^{\mathrm{e}}$ & $3,36 \mathrm{MW}^{\mathrm{d}}$ \\
\hline Eletricidade vendida & $6,6 \mathrm{GWh}_{\mathrm{e}} / \mathrm{ano}^{\mathrm{f}}$ & $19,5 \mathrm{GWh}_{\mathrm{e}} / \mathrm{ano}^{\mathrm{d}}$ \\
\hline Investimento inicial* & $\mathrm{R} \$ 16.690 .000^{\mathrm{g}}$ & $\mathrm{R} \$ 20.833 .802^{\mathrm{g}}$ \\
\hline Custo anual $O \& M^{*}$ & $\mathrm{R} \$ 803.136 / \mathrm{ano}^{\mathrm{g}}$ & $\mathrm{R} \$ 1.284 .480 / \mathrm{ano}^{\mathrm{g}}$ \\
\hline Custo de produção do MWh & $\mathrm{R} \$ 540 / \mathrm{MWh}_{\mathrm{e}}{ }^{\mathrm{d}}$ & $\mathrm{R} \$ 240 / \mathrm{MWh}_{\mathrm{e}}{ }^{\mathrm{d}}$ \\
\hline
\end{tabular}

* No caso do cenário otimista, o investimento inicial e o custo de O\&M são incrementados devido à maior potencia instalada.

Fonte: a) Tabela 19; b) Valores preestabelecidos no estudo; c)Tabela 18; d) Calculado pelo autor;

e) Equação 22; f) Equação 21; g) Tabela 38; 
Com este exercício, pode-se ver a importância da melhora da eficiência do processo de biodigestão na produção de biogás. Ainda assim, em um cenário otimista o preço da energia elétrica gerada com biogás de vinhaça é pouco competitivo se comparado com o preço indicado anteriormente de $\mathrm{R} \$ 202,45 / \mathrm{MWh}$ para as térmicas de bagaço.

Até este ponto da análise, não foi contabilizada economicamente a redução de emissões de GEEs que a implantação da biodigestão produz, uma vez que atualmente o preço do Certificate Emission Reduction (CER) é praticamente nulo ${ }^{52}$. A seguir, realiza-se o exercício de calcular os preços que deveriam ter o $\mathrm{MWh}_{\mathrm{e}}$ e o CER, para que a implantação desta tecnologia fosse economicamente atrativa, com um valor mínimo da TIR $=21 \%$, pois foi esta a taxa encontrada no Cenário 1.

Na Figura 37 pode ser observada a relação que existe entre o preço do MWhe e da tCO2eq evitada, para obter um investimento com uma TIR $=21 \%$. Esta função indica os valores que devem adquirir as duas variáveis para manter atrativa a geração de eletricidade com biogás de vinhaça, desde o ponto de vista econômico.

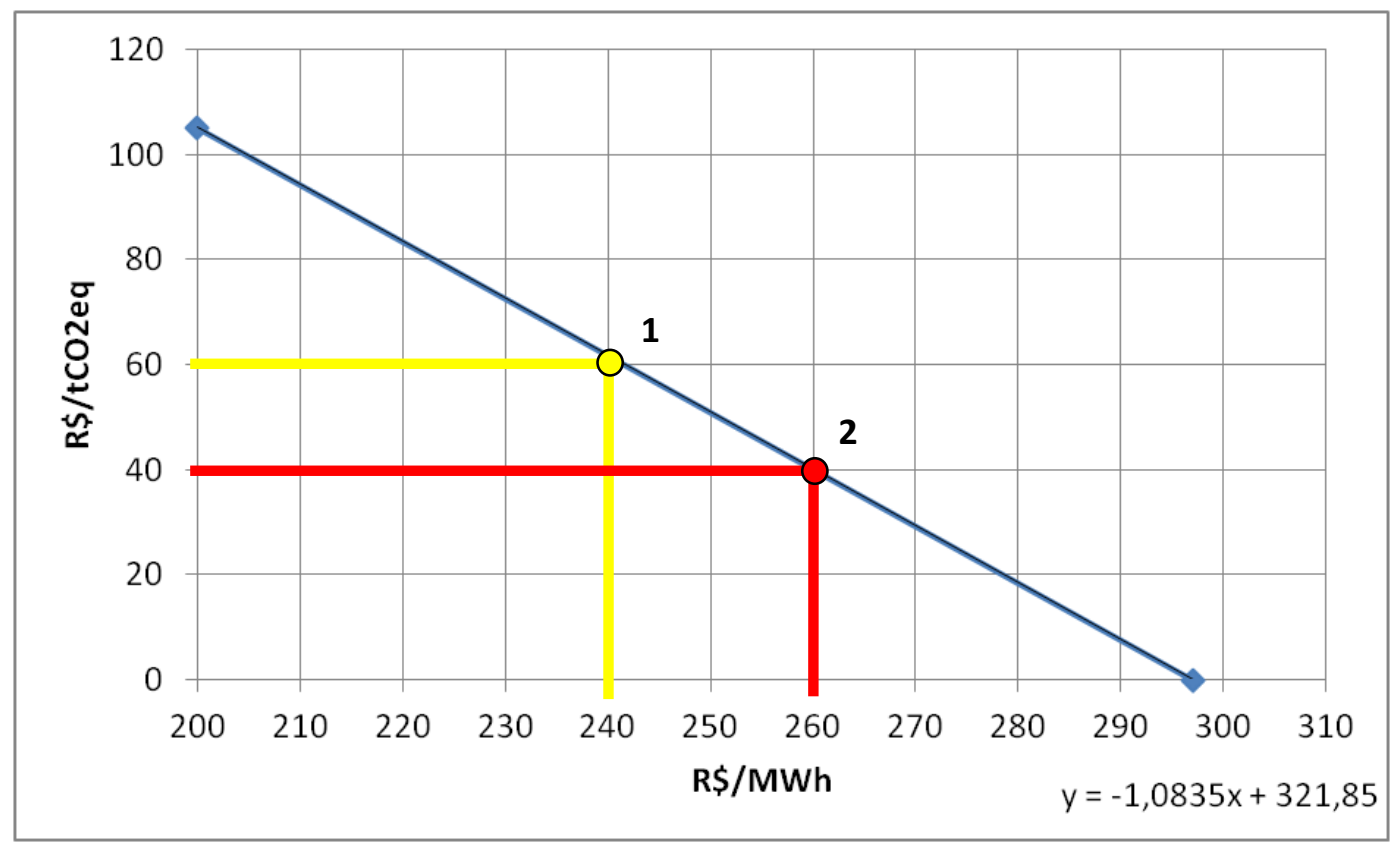

Figura 37. Relação entre o preço da eletricidade e do CER para que o Cenário 2 tenha uma TIR $=21 \%$. Fonte: Autor.

Na Figura 37, foram tomados como exemplo dois pontos que fazem com que a TIR do investimento seja igual a $21 \%$. No ponto número 1 , a eletricidade teria um preço de $\mathrm{R} \$ 240 / \mathrm{MWh}$, sendo necessário que o CER atinja os $\mathrm{R} \$ 60 / \mathrm{tCO}_{2}$ eq. No ponto número 2, o

\footnotetext{
${ }^{52}$ O preço médio do CER em dezembro de 2014 foi de $0,08 €$ no mercado Spot (sendeco2.com)
} 
preço da eletricidade seria de $\mathrm{R} \$ 260 / \mathrm{MWh}$, correspondendo a um preço do CER de aproximadamente $\mathrm{R} \$ 40 / \mathrm{tCO}_{2}$ eq para que o projeto tenha atratividade.

Em definitivo, a regulação do preço da eletricidade e das emissões no entorno destes valores criaria um cenário no qual o investimento na biodigestão com geração de eletricidade seria atrativo, como mostra a Tabela 41.

Tabela 41. Variação dos indicadores financeiros no Cenário 2 em função do preço da eletricidade e das CERs.

\begin{tabular}{lcc}
\hline Investimento inicial & \multicolumn{2}{c}{$\mathrm{R} \$ 20.833 .802^{\mathrm{a}}$} \\
Custo anual O\&M & $\mathrm{R} \$ 1.284 .480 / \mathrm{ano}^{\mathrm{a}}$ \\
Vida útil & $18 \mathrm{anos}^{\mathrm{b}}$ \\
Taxa de desconto & $15 \%^{\mathrm{b}}$ \\
TIR & 1 & $21 \%^{\mathrm{c}}$ \\
Ponto da Figura 37 & $\mathrm{R} \$ 240 / \mathrm{MW}_{\mathrm{e}}^{\mathrm{c}}$ & 2 \\
Preço da eletricidade & $\mathrm{R} \$ 60 / \mathrm{tCO}_{2} \mathrm{eq}^{\mathrm{c}}$ & $\mathrm{R}^{\mathrm{c}} / 260 \mathrm{MW}_{\mathrm{e}}{ }^{\mathrm{c}}$ \\
Preço da CER & $\mathrm{R} \$ 6.872 .708^{\mathrm{c}}$ & $\mathrm{R}^{\mathrm{c}} \$ 40 / \mathrm{tCO}_{2} \mathrm{eq}^{\mathrm{c}}$ \\
VPL & $9 \operatorname{anos}^{\mathrm{c}}$ & $\mathrm{R}^{\mathrm{c}} \$ 6.872 .708^{\mathrm{c}}$ \\
Payback descontado & & $9 \mathrm{anos}^{\mathrm{c}}$ \\
\hline
\end{tabular}

Fonte: a) Tabela 40; b) Valores preestabelecidos no estudo; c) Calculado pelo autor.

Esta tecnologia não está muito longe da viabilidade econômica, mas para fazer o investimento atrativo ainda seriam necessários a intervenção no preço pago pela eletricidade e um mercado de carbono registrando um valor próximo a $€ 20 / \mathrm{tCO}_{2} \mathrm{eq}^{53}$, valores unicamente atingidos durante o ano 2008 (Figura 38).

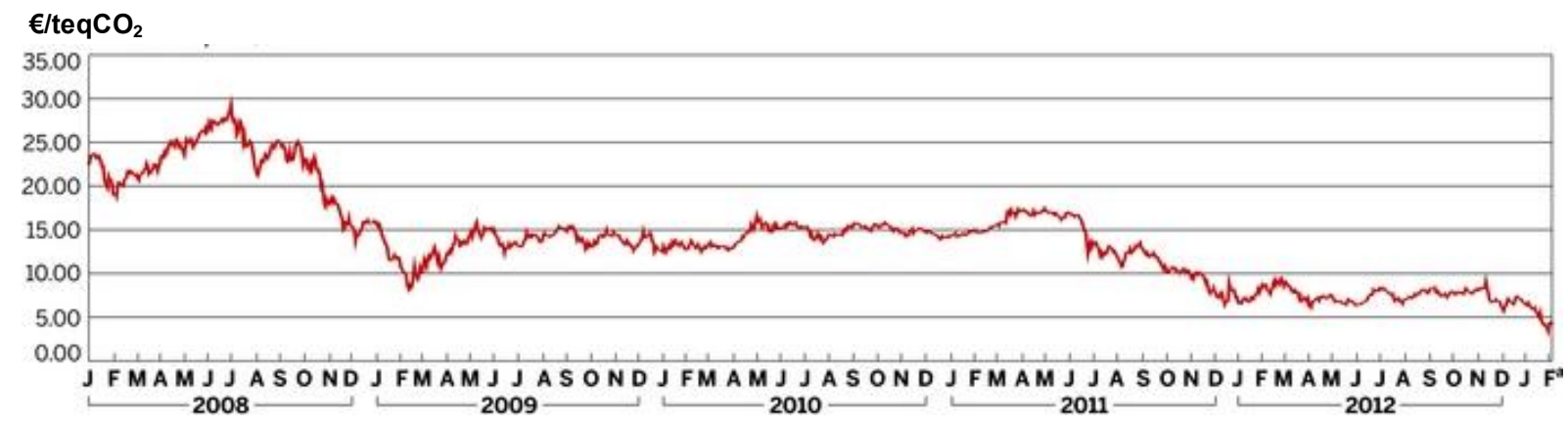

Figura 38. Histórico do preço das CER.

Fonte: Thomson Reuters Point Carbon, 2014 ${ }^{54}$.

\footnotetext{
${ }^{53}$ Taxa de cambio no 08/12/14: $€ 1=\mathrm{R} \$ 3,18$ (BANCO CENTRAL DO BRASIL, 2014).

${ }^{54} \mathrm{http}$ ///financial.thomsonreuters.com/
} 


\subsection{Cenário 3: Incineração com geração de eletricidade}

Para este cenário foram considerados, por um lado, os custos correspondentes a uma planta de concentração de vinhaça e, por outro, uma central de cogeração termoelétrica de ciclo Rankine com queimadores torsionais de vinhaça atomizada e de gás natural. $\mathrm{O}$ concentrador evaporativo deve ser capaz de tratar toda a vinhaça produzida pela destilaria, atingindo uma concentração de $65^{\circ} \mathrm{Bx}$. Por isso a capacidade desta instalação é 4 vezes superior à do Cenário 1. É esperado um aumento na necessidade de limpeza e manutenção devido às altas concentrações da vinhaça que favorecem incrustações, encarecendo, assim a operação.

O custo específico por $\mathrm{kW}$ instalado de uma central termoelétrica a biomassa depende da sua potencia nominal, como mostra a Tabela 42 .

Tabela 42. Custo de instalação de pequenas centrais de biomassa.

\begin{tabular}{cc}
\hline $\begin{array}{c}\text { Potência instalada } \\
(\mathbf{k W})\end{array}$ & $\begin{array}{c}\text { Custos de referência } \\
(\mathbf{\$ U S} / \mathbf{k W})\end{array}$ \\
\hline 1.000 & 2.588 \\
1.600 & 2.004 \\
3.000 & 1.568 \\
5.000 & 1.383 \\
\hline
\end{tabular}

Fonte: Eletrobrás (1985).

Utilizando os custos de referência da Tabela 42, para uma potência elétrica de geração instalada 2,3 $\mathrm{MW}_{\mathrm{e}}$ (Equação 38) foi assumido o valor $\mathrm{R} \$ 4.000 / \mathrm{kW}$. Este valor pode ser ainda superior considerando as características especiais da instalação, tais como a necessidade de um elevado numero de sopradores de cinzas, de um tratamento de gases de exaustão para abater a significativa formação de $\mathrm{NO}_{\mathrm{x}}$ e $\mathrm{SO}_{\mathrm{x}}$, e de os queimadores especiais referidos anteriormente. Os custos estimados para o Cenário 3 são apresentados na Tabela 43.

Tabela 43. Custos no Cenário 3.

\begin{tabular}{llll}
\hline & Preço unitário & Unidades & Total \\
\hline Instalação & & & \\
Concentrador & $\mathrm{R} \$ 80.000 /(\mathrm{t} / \mathrm{h})$ & $160 \mathrm{t} / \mathrm{h}$ & $\mathrm{R} \$ 12.800 .000$ \\
Termoelétrica a vapor & $\mathrm{R} \$ 4.000 / \mathrm{kW}$ & $2.300 \mathrm{~kW}$ & $\mathrm{R} \$ 9.200 .000$ \\
\hline Custo total de instalação & & & $\mathrm{R} \$ 22.000 .000$ \\
\hline
\end{tabular}




\begin{tabular}{llll}
\hline Operação & & & \\
Soda Cáustica & $\mathrm{R} \$ 800 / \mathrm{t}$ & $8 \mathrm{t} / \mathrm{semana}$ & $\mathrm{R} \$ 221.000$ /ano \\
Gás natural & $\mathrm{R} \$ 1,4 / \mathrm{m}^{3}$ & $1.200 .000 \mathrm{~m}^{3}$ & $\mathrm{R} \$ 1.680 .000 /$ ano \\
Mão de obra & $\mathrm{R} \$ 35.000 /$ operário & 3 operários & $\mathrm{R} \$ 105.000 / \mathrm{ano}$ \\
Insumos + administração & & & $\mathrm{R} \$ 60.000 /$ ano \\
\hline Manutenção & $\mathrm{R} \$ 300.000$ & $1 / \mathrm{ano}$ & $\mathrm{R} \$ 300.000 /$ ano \\
Hidrojateamento & & $\mathrm{R} \$ 350.000 /$ ano \\
Mão de Obra e Materiais & & $\mathrm{R} \$ 2.716 .000 / \mathrm{ano}$ \\
\hline Custo anual O\&M & & \\
\hline
\end{tabular}

Fonte: Autor baseado em dados dos fabricantes de equipamentos.

Somando os custos de ambas as instalações e tomando os valores mostrados na Tabela 44, calcula-se o custo de produção da eletricidade da mesma forma que foi feito para o cenário anterior.

Tabela 44. Indicadores financeiros do investimento no Cenário 3

\begin{tabular}{ll}
\hline Investimento inicial & $\mathrm{R} \$ 22.000 .000^{\mathrm{a}}$ \\
Custo anual O\&M & $\mathrm{R} \$ 2.716 .000 / \mathrm{ano}^{\mathrm{a}}$ \\
Eletricidade vendida & $10,8 \mathrm{GWh}_{\mathrm{e}} / \mathrm{ano}^{\mathrm{b}}$ \\
Economia operacional na fertirrigação & $\mathrm{R} \$ 3.840 .000 / \mathrm{ano}^{\mathrm{c}}$ \\
Economia de água & $\mathrm{R} \$ 913.536 / \mathrm{ano}^{\mathrm{c}}$ \\
Vida útil & $18 \mathrm{anos}^{\mathrm{d}}$ \\
Taxa de desconto & $15 \%{ }^{\mathrm{d}}$ \\
\cline { 2 - 2 } Custo de produção da eletricidade & $\mathrm{R} \$ 580 / \mathrm{MWh}^{\mathrm{c}}$ \\
& $\mathrm{R} \$ 230 / \mathrm{MWh}\left(\operatorname{com}\right.$ economia na fertirrigação) ${ }^{\mathrm{c}}$ \\
& $\mathrm{R} \$ 145 / \mathrm{MWh}(\text { com economia de água })^{\mathrm{c}}$ \\
\hline
\end{tabular}

Fonte: a) Tabela 43; b) Equação 37 c) Calculado pelo autor; d) Valores preestabelecidos no estudo.

Observa-se um alto custo de produção da eletricidade de $\mathrm{R} \$ 580 / \mathrm{MWh}$, mas neste valor não foi contabilizando a anulação do custo em fertirrigação devido à eliminação total do volume de vinhaça, o qual representa uma economia operacional para a usina de $\mathrm{R} \$ 3.840 .000 /$ ano. Portanto, incluindo este valor como um ganho na produção de eletricidade, atinge-se um valor de $\mathrm{R} \$ 230 / \mathrm{MWh}$. Os custos com fertilização química não são incrementados, pois se considera a recuperação completa do potássio da vinhaça por meio das cinzas resultantes da sua combustão.

Tampouco foi contabilizado o custo da água economizada com a implantação da incineração, porque não existe hoje um pagamento por parte das usinas no uso deste recurso. Caso fosse exigido este pagamento, e estabelecendo como referência o preço de $R \$ 1 / \mathrm{m}^{3}$ de 
água, a economia seria de $\mathrm{R} \$ 913.536 /$ ano. Incluindo isto como um ganho, o preço de produção cairia até $\mathrm{R} \$ 145 / \mathrm{MWh}$, observando-se o grande impacto que pode ter o custo da captação de água na viabilização desta tecnologia.

Por outro lado, foi contabilizado neste cálculo o custo do volume de gás natural consumido para a incineração, mas não o de seu transporte por meio de gasoduto ou caminhão. Sem dúvida, este pode ser um fator limitante para a instalação deste tipo de sistema naquelas localizações longe da rede de abastecimento.

A seguir, é feita a mesma análise que no cenário anterior, contabilizando economicamente a redução de emissões de GEEs que produz a implantação da incineração, e determinando os preços que deveriam ter a eletricidade e o CER para obter um valor mínimo da $\mathrm{TIR}=21 \%$. Esta taxa foi encontrada no Cenário $1 \mathrm{e}$, por isto, também foi usada como referência nos cenários 2 e 3 .

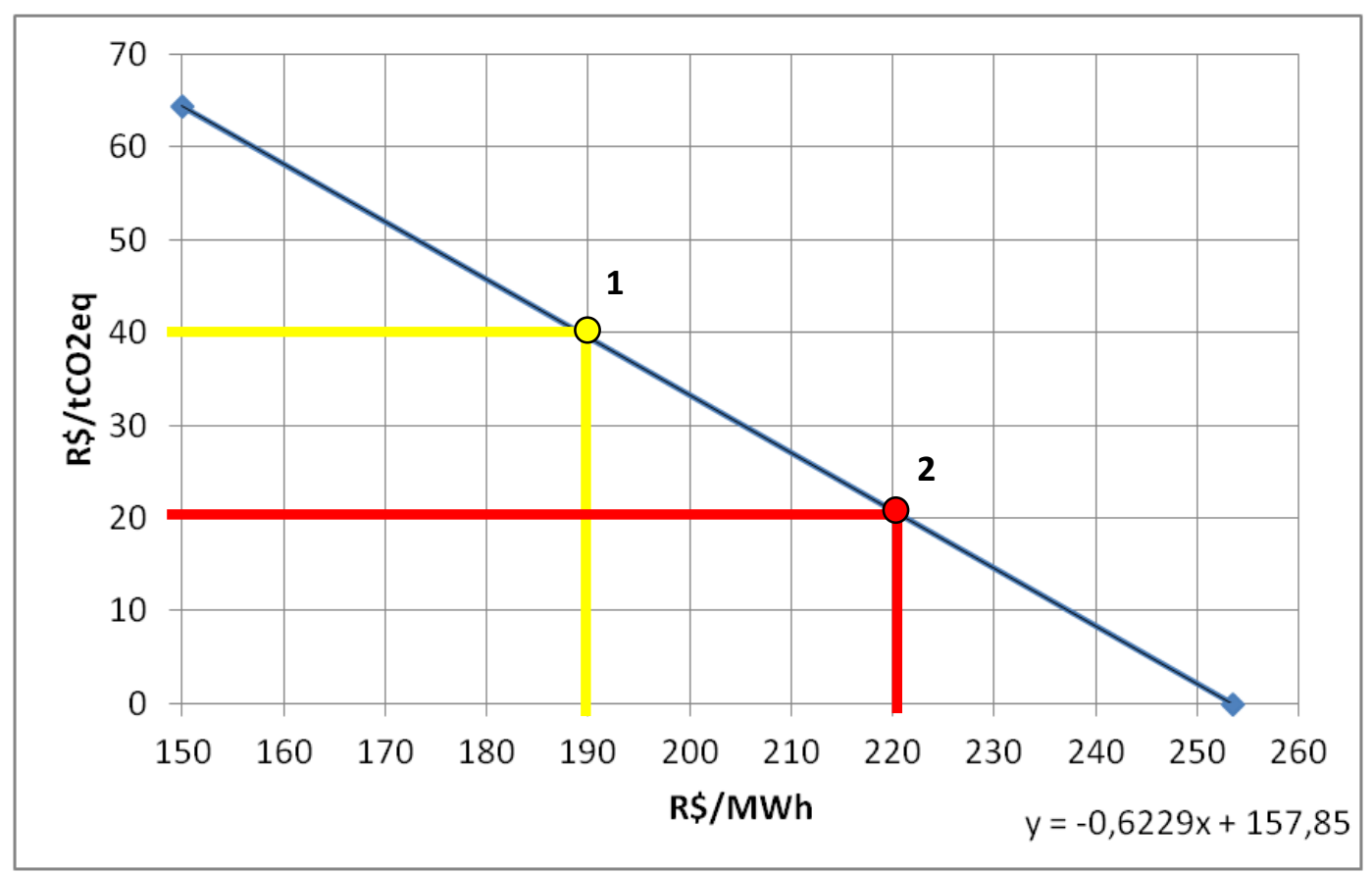

Figura 39. Relação entre o preço da eletricidade e do CER para que o Cenário 3 tenha uma TIR $=21 \%$. Fonte: Autor.

$\mathrm{Na}$ Figura 39 pode ser observada a relação do preço do $\mathrm{MWh}_{\mathrm{e}}$ e da $\mathrm{tCO}_{2}$ eq evitada, para obter um investimento com uma TIR $=21 \%$. Esta função indica os valores que devem adquirir as duas variáveis para manter atrativa a geração de eletricidade incinerando a vinhaça, a partir do ponto de vista econômico. Como exemplo, no ponto número 1 , a eletricidade tem um preço de $\mathrm{R} \$ 190 / \mathrm{MWh}$, sendo necessário que o CER tenha um preço de $\mathrm{R} \$ 40 / \mathrm{tCO}_{2}$ eq. No ponto número 2, a eletricidade tem um preço de $\mathrm{R} \$ 220 / \mathrm{MWh}$,correspondendo a um preço do CER de $\mathrm{R} \$ 20 / \mathrm{tCO}_{2}$ eq. 
Neste Cenário 3, a regulação do preço da eletricidade e das emissões em valores próximos aos indicados criaria um cenário onde seria atrativo o investimento na incineração conjunta de vinhaça e gás natural com geração de eletricidade, como mostra a Tabela 45. Ainda assim, no Brasil, não existem instalações de porte industrial funcionando com vinhaça de etanol de cana de açúcar e, portanto, os custos operacionais e de manutenção são unicamente aproximações. A magnitude destes custos é de vital importância, pois a produção de vinhaça de $65^{\circ} \mathrm{Bx}$ acarretará problemas de incrustações nos últimos efeitos do evaporador, e seu elevado teor de cinzas pode ocasionar problemas na caldeira. Por isso, seria necessária sua implantação em escala piloto.

Tabela 45. Variação dos indicadores financeiros no Cenário 3 em função do preço da eletricidade e do CER.

\begin{tabular}{lcc}
\hline Investimento inicial & \multicolumn{2}{c}{$\mathrm{R} \$ 22.000 .000^{\mathrm{a}}$} \\
Custo anual O\&M & $\mathrm{R} \$ 2.716 .000 / \mathrm{ano}^{\mathrm{a}}$ \\
Economia operacional na fertirrigação & $\mathrm{R} \$ 3.840 .000 / \mathrm{ano}^{\mathrm{b}}$ \\
Economia de água & $\mathrm{R} \$ 913.536 / \mathrm{ano}^{\mathrm{b}}$ \\
Vida útil & $18 \mathrm{anos}^{\mathrm{c}}$ \\
Taxa de desconto & $15 \%^{\mathrm{c}}$ & \\
TIR & $21 \%^{\mathrm{c}}$ & \\
Ponto daFigura 39 & 1 & 2 \\
Preço da eletricidade & $\mathrm{R} \$ 190 / \mathrm{MW}_{\mathrm{e}}{ }^{\mathrm{b}}$ & $\mathrm{R} \$ 220 / \mathrm{MW}_{\mathrm{e}}{ }^{\mathrm{b}}$ \\
Preço do CER & $\mathrm{R} \$ 40 / \mathrm{tCO}_{2} \mathrm{eq}{ }^{\mathrm{b}}$ & $\mathrm{R} \$ 20 / \mathrm{tCO}_{2} \mathrm{eq}^{\mathrm{b}}$ \\
VPL & $\mathrm{R} \$ 7.258 .165^{\mathrm{b}}$ & $\mathrm{R} \$ 7.258 .165^{\mathrm{b}}$ \\
Payback descontado & $9^{\mathrm{b}}$ & $9^{\mathrm{b}}$ \\
\hline
\end{tabular}

Fonte: a) Tabela 43; b) Calculado pelo autor; c) Valores preestabelecidos no estudo.

Comparado com o cenário da biodigestão, observa-se que os preços da eletricidade e da CER devem ser inferiores para dar viabilidade ao investimento. Esta situação favorável é devida à eliminação total das despensas em fertirrigação e a hipotética cobrança da captação de água, sendo estas vantagens que não possui a biodigestão.

\subsection{Cenário 4: Biodigestão com concentração e uso veicular}

Neste último cenário considerado, pretende-se avaliar tanto o uso veicular do biometano extraído do biogás de vinhaça, como a inclusão do uso da concentração pode influenciar no desempenho econômico do sistema de processamento. Para este fim, o Cenário 4 é desdobrado em duas possibilidades: uma sem a instalação do concentrador e a outra incluindo esta tecnologia. No primeiro caso, são contabilizados os custos do sistema de biodigestão tipo 
IC, do dessulfurificador, de uma planta para a separação do $\mathrm{CO}_{2}$ tipo water scrubber utilizada na purificação do biogás até um 98\% metano (upgrading) e de uma estação de Gás Natural Veicular (GNV) com compressão até 220 bar. Também é adicionada a compra de um motogerador a biogás dimensionado para suprir, a partir do biogás, as cargas internas de todos estes sistemas. O valor destes equipamentos, dimensionados para o caso estudado, aparece na Tabela 46.

Tabela 46. Custos no Cenário 4 sem concentração.

\begin{tabular}{llll}
\hline & Preço unitário & Unidades & Total \\
\hline Instalação & $\mathrm{R} \$ 110 /(\mathrm{kg} \mathrm{DQO} / \mathrm{dia})$ & $116.000 \mathrm{~kg} \mathrm{DQO} / \mathrm{dia}$ & $\mathrm{R} \$ 12.760 .000$ \\
Biodigestor & $\mathrm{R} \$ 1.330 .000$ & $1.000 \mathrm{Nm} 3 / \mathrm{h}$ & $\mathrm{R} \$ 1.330 .000$ \\
Dessulfurificador & $\mathrm{R} \$ 5.100 .000$ & $1.000 \mathrm{Nm}^{3} / \mathrm{h}$ & $\mathrm{R} \$ 5.100 .000$ \\
Upgrading & $\mathrm{R} \$ 500.000$ & $300 \mathrm{Nm}^{3} / \mathrm{h}$ & $\mathrm{R} \$ 500.000$ \\
Compressor & $\mathrm{R} \$ 2.000 / \mathrm{kW}$ & $500 \mathrm{~kW}$ & $\mathrm{R} \$ 1.000 .000$ \\
Motogerador & & & $\mathrm{R} \$ 20.690 .000$ \\
\hline Custo total de instalação & $\mathrm{R} \$ 0,018 \mathrm{~kg} \mathrm{de} \mathrm{DQO}$ & $27.840 .000 \mathrm{~kg}$ & $\mathrm{R} \$ 501.000 / \mathrm{ano}$ \\
\hline $\begin{array}{l}\text { Operação } \\
\text { Biodigestor }+ \\
\text { dessulfurificador }\end{array}$ & & $\mathrm{DQO} / \mathrm{ano}$ & $\mathrm{R} \$ 150.000 / \mathrm{ano}$ \\
Upgrading & & $1.000 \mathrm{Nm} 3 / \mathrm{h}$ & $\mathrm{R} \$ 50.000 / \mathrm{ano}$ \\
Compressor & $\mathrm{R} \$ 40,00 / \mathrm{MWh}$. & $\mathrm{R} \$ 116.000 / \mathrm{ano}$ \\
\hline Motogerador & & $2.904 \mathrm{MWh} / \mathrm{ano}$ & $\mathrm{R} \$ 817.000 / \mathrm{ano}$ \\
\hline Custo anual O\&M & & & \\
\hline
\end{tabular}

Fonte: Autor baseado em dados dos fabricantes de equipamentos.

A seguir é calculado o custo da segunda possibilidade, integrando a concentração no sistema (Tabela 47). É considerado que os custos de instalação do concentrador se reduziriam um $20 \%$ ao antepor o sistema de biodigestão. Esta consideração se baseia no fato de que o pH da vinhaça passaria a ser neutro, o que permitiria empregar tipos de aço mais econômicos na construção dos concentradores ${ }^{55}$. Igualmente, entende-se que os custos de operação e manutenção do concentrador também cairiam devido à diminuição da corrosão e da presença de sólidos que promovem incrustações e obrigam a limpezas frequentes. Por isto, é assumido $30 \%$ de redução nestas despesas. Estas afirmações precisam ser testadas porque ainda não existem sistemas integrados de biodigestão e concentração instalados.

\footnotetext{
55 Atualmente é utilizado aço austenítico tipo 304L para suportar a corrosão.
} 
Tabela 47. Custos no Cenário 4 com concentração.

\begin{tabular}{llll}
\hline & Preço unitário & Unidades & Total \\
\hline Instalação & $\mathrm{R} \$ 64.000 /(\mathrm{t} / \mathrm{h})$ & $40 \mathrm{t} / \mathrm{h}$ & $\mathrm{R} \$ 2.560 .000$ \\
Concentrador & $\mathrm{R} \$ 110 /(\mathrm{kg} \mathrm{DQO} / \mathrm{dia})$ & $116.000 \mathrm{~kg} \mathrm{DQO} / \mathrm{dia}$ & $\mathrm{R} \$ 12.760 .000$ \\
Biodigestor & $\mathrm{R} \$ 1.330 .000$ & $1.000 \mathrm{Nm} / \mathrm{h}$ & $\mathrm{R} \$ 1.330 .000$ \\
Dessulfurificador & $\mathrm{R} \$ 5.100 .000$ & $1.000 \mathrm{Nm}^{3} / \mathrm{h}$ & $\mathrm{R} \$ 5.100 .000$ \\
Upgrading & $\mathrm{R} \$ 500.000$ & $300 \mathrm{Nm}^{3} / \mathrm{h}$ & $\mathrm{R} \$ 500.000$ \\
Compressor & $\mathrm{R} \$ 2.000 / \mathrm{kW}$ & $600 \mathrm{~kW}$ & $\mathrm{R} \$ 1.200 .000$ \\
Motogerador & & & $\mathrm{R} \$ 23.500 .000$ \\
\hline Custo total de instalação & & & $\mathrm{R} \$ 73.500 / \mathrm{ano}$ \\
\hline Operação & & $27.840 .000 \mathrm{~kg} \mathrm{DQO} / \mathrm{ano}$ & $\mathrm{R} \$ 501.120 / \mathrm{ano}$ \\
Concentrador & $\mathrm{R} \$ 0,018 \mathrm{~kg} \mathrm{de} \mathrm{DQO}$ & $1.000 \mathrm{Nm} / \mathrm{h}$ & $\mathrm{R} \$ 150.000 / \mathrm{ano}$ \\
$\begin{array}{l}\text { Biodigestor }+ \\
\text { dessulfurificador }\end{array}$ & $\mathrm{R} \$ 5.100 .000$ & $300 \mathrm{Nm} / \mathrm{h}$ & $\mathrm{R} \$ 50.000 / \mathrm{ano}$ \\
$\begin{array}{l}\text { Upgrading } \\
\text { Compressor }\end{array}$ & $\mathrm{R} \$ 40,00 / \mathrm{MWh}$. & $\mathrm{R} \$ 140.000 / \mathrm{ano}$ \\
\hline Motogerador & & $\mathrm{R} \$ 915.000 / \mathrm{ano}$ \\
\hline Custo anual O\&M & & $\mathrm{MWh} / \mathrm{ano}$ & \\
\hline
\end{tabular}

Fonte: Autor baseado em dados dos fabricantes de equipamentos.

Uma vez conhecidos os custos destas instalações, avalia-se qual seria o custo do biometano comprimido com especificações para seu uso veicular. O custo do biometano é expressado em R\$ por "litro de diesel equivalente", sendo esta medida definida como o custo de produzir uma quantidade de metano capaz de proporcionar a mesma energia térmica que um litro de diesel fóssil ${ }^{56}$. Utilizando os valores da Tabela 48, é calculado um custo de produção do "litro de diesel equivalente" de $\mathrm{R} \$ 2,79 / 1$ no caso de não incorporar concentração, e de $\mathrm{R} \$ 2,59 / 1$ se este for instalado.

Tabela 48. Custo de produção do litro diesel equivalente no cenário 3

\begin{tabular}{|c|c|c|}
\hline & $\begin{array}{l}\text { Biodigestão + } \\
\text { Uso veicular }\end{array}$ & $\begin{array}{c}\text { Biodigestão + } \\
\text { Concentração + } \\
\text { Uso veicular }\end{array}$ \\
\hline Investimento inicial & $\mathrm{R} \$ 20.690 .000^{\mathrm{a}}$ & $\mathrm{R} \$ 23.500 .000^{\mathrm{b}}$ \\
\hline Custo anual O\&M & $\mathrm{R} \$ 817.000 / \mathrm{ano}^{\mathrm{a}}$ & $\mathrm{R} \$ 914.020 / \mathrm{ano}^{\mathrm{b}}$ \\
\hline Diminuição do custo em fertirrigação & $\mathrm{R} \$ 0 / \mathrm{ano}^{\mathrm{c}}$ & $\mathrm{R} \$ 904.000 / \mathrm{ano}^{\mathrm{c}}$ \\
\hline Diminuição do custo na captação de água & $\mathrm{R} \$ 0 / \mathrm{ano}^{\mathrm{c}}$ & $\mathrm{R} \$ 226.000 /$ ano $^{\mathrm{c}}$ \\
\hline Produção de volume de diesel equivalente & $1.545 \mathrm{~m}^{3} / \mathrm{ano}^{\mathrm{d}}$ & $1.485 \mathrm{~m}^{3} / \mathrm{ano}^{\mathrm{d}}$ \\
\hline Vida útil & $18 \operatorname{anos}^{\mathrm{e}}$ & $18 \operatorname{anos}^{\mathrm{e}}$ \\
\hline Taxa de desconto & $15 \%^{\mathrm{e}}$ & $15 \%^{\mathrm{e}}$ \\
\hline Custo de produção do "litro de diesel equivalente" & $\mathrm{R} \$ 2,79 / 1^{\mathrm{c}}$ & $\mathrm{R} \$ 2,43 / 1^{\mathrm{c}}$ \\
\hline
\end{tabular}

Fonte: a) Tabela 46; b) Tabela 47; c) Calculado pelo autor; d) Equação 41; e) Valores preestabelecidos no estudo.

\footnotetext{
${ }^{56}$ Utilizando os valores correspondentes do PCI do diesel e do metano, pode ser calculado que $1,014 \mathrm{Nm}^{3} \mathrm{de}$ $\mathrm{CH}_{3}$ produz a mesma energia térmica que um litro de diesel.
} 
Contabilizado o custo da água economizada com a implantação do concentrado a um preço de $\mathrm{R} \$ 1 / \mathrm{m}^{3}$ de água, o ganho seria de $\mathrm{R} \$ 226.000 /$ ano, o que diminuiria o custo do "litro de diesel equivalente" até $\mathrm{R} \$ 2,43 / 1$. Justamente, este último valor de produção coincide com o preço médio do diesel na bomba no Estado de São Paulo ${ }^{57}$, fazendo com que o investimento não seja interessante economicamente.

Em nenhum dos dois casos foram contabilizados os custos de transformação dos veículos para uso de GNV. Este custo de transformação se encontra entre $R \$ 2.000$ e $R \$ 3.000$ para veículos leves, sendo superior para veículos médios. Para veículos pesados como os treminhões, onde se encontra o grosso do consumo de combustível da usina, não é possível a conversão, necessitando uma renovação da frota em bicombustível para poder utilizar GNV. Se a usina não estiver planejando renovar sua frota se requereria incluir este custo no investimento inicial, agravando a inviabilidade econômica do projeto.

A seguir, será feita uma análise semelhante a dos cenários anteriores, neste caso variando o preço do diesel fóssil na bomba e o do CER, procurando os valores que fazem com que a TIR do investimento seja igual a $21 \%$. Também será incluído um custo de renovação parcial da frota para o uso bicombustível de 5 milhões de reais.

NaFigura 40. Figura 40, mostra-se a relação que existe entre o preço do litro de diesel e da $\mathrm{tCO}_{2}$ eq evitada, para obter um investimento com uma $\mathrm{TIR}=21 \%$.

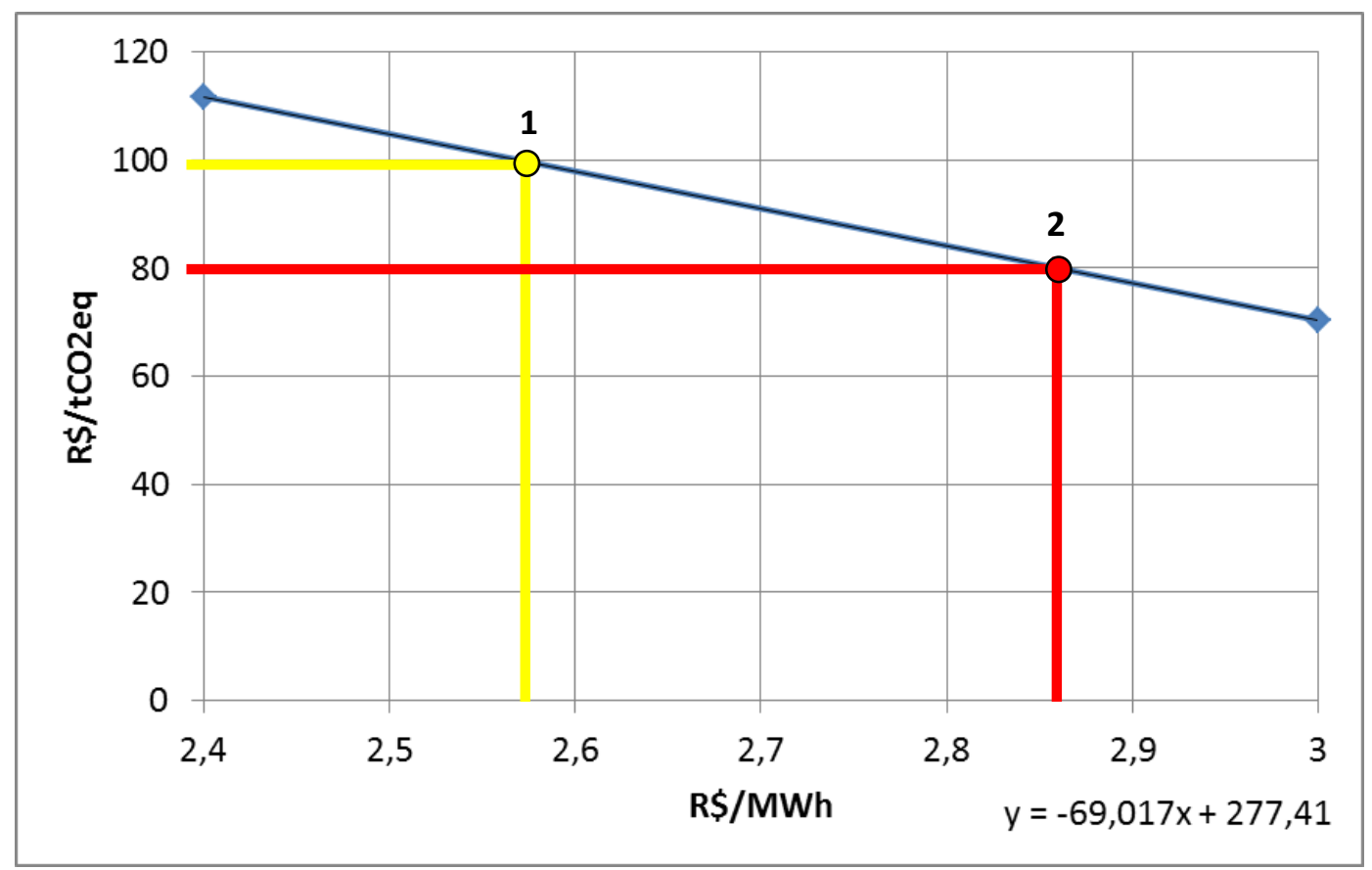

Figura 40. Relação entre o preço da eletricidade e do CER para que o Cenário 4 tenha uma TIR = 21\%. Fonte: Autor

\footnotetext{
${ }^{57}$ Síntese dos Preços Praticados - SÃO PAULO Resumo I - Diesel R\$/1 Período : De 19/10/2014 a 25/10/2014
} 
Esta função indica os valores que devem adquirir as duas variáveis para manter atrativo desde o ponto de vista econômico o uso veicular do biogás de vinhaça substituindo o diesel. Neste Cenário 4, o preço do diesel na bomba deveria atingir valores no entorno de $\mathrm{R} \$ 2,7 / 1$ e um mercado de carbono registrando valores de $€ 30 / t$ para criar um cenário no qual o investimento seria atrativo, como mostra a Tabela 49.

Tabela 49. Variação dos indicadores financeiros no Cenário 4 em função do preço do diesel e do CER.

\begin{tabular}{|c|c|c|}
\hline Investimento inicial & \multicolumn{2}{|c|}{$\mathrm{R} \$ 28.500 .000^{\mathrm{a}}$} \\
\hline Custo anual O\&M & \multicolumn{2}{|c|}{$\mathrm{R} \$ 914.020 / \mathrm{ano}^{\mathrm{a}}$} \\
\hline Economia operacional na fertirrigação & \multicolumn{2}{|c|}{$\mathrm{R} \$ 904.000 / \mathrm{ano}^{\mathrm{b}}$} \\
\hline Economia de água & \multicolumn{2}{|c|}{$\mathrm{R} \$ 226.000 / \mathrm{ano}^{\mathrm{b}}$} \\
\hline Vida útil & \multicolumn{2}{|c|}{$18 \operatorname{anos}^{c}$} \\
\hline Taxa de desconto & \multicolumn{2}{|c|}{$15 \%^{\mathrm{c}}$} \\
\hline TIR & \multicolumn{2}{|c|}{$21 \%^{\mathrm{c}}$} \\
\hline Ponto da Figura 40 & 1 & 2 \\
\hline Preço do diesel & $\mathrm{R} \$ 2,57 / 1^{\mathrm{b}}$ & $\mathrm{R} \$ 2,86 / 1^{\mathrm{b}}$ \\
\hline Preço do CER & $\mathrm{R} \$ 100 / \mathrm{tCO}_{2} \mathrm{eq}^{\mathrm{b}}$ & $\mathrm{R} \$ 80 / \mathrm{tCO}_{2} \mathrm{eq}^{\mathrm{b}}$ \\
\hline VPL & $\mathrm{R} \$ 9.402 .336^{\mathrm{b}}$ & $\mathrm{R} \$ 9.402 .336^{\mathrm{b}}$ \\
\hline Payback descontado & 9 anos $^{b}$ & 9 anos $^{b}$ \\
\hline
\end{tabular}

Fonte: a) Tabela 47; b) Calculado pelo autor; c) Valores preestabelecidos no estudo.

Como pode ser observado, o fator fundamental para a viabilização econômica do uso veicular do biogás é o preço do diesel. Na situação atual, os incentivos para a diminuição de emissões de GEEs e para a melhora do balanço energético do etanol seriam fundamentais para conseguir implantar esta tecnologia. É importante, também, a questão da mudança da frota para bicombustível, pois existem kits no mercado para a conversão de veículos leves e médios relativamente econômicos, mas não para os pesados, o que força a esperar a renovação da frota.

\subsection{Resultados da avaliação econômica}

Na Tabela 50 são resumidos os resultados da avaliação econômica com respeito ao cenário de referência. Nesta tabela pode ser observado que o único cenário viável economicamente, nas condições atuais, é o cenário da concentração. Para serem atrativos os demais casos, seriam necessárias bonificações pela diminuição de emissões de GEEs e da captação de água, como também seriam indispensáveis preços regulados da eletricidade e do diesel. Como já foi comentado anteriormente, esta pode ser a explicação de que a tecnologia 
da concentração é a que vem sendo instalada nas usinas do país, enquanto as outras opções permanecem inviáveis.

O investimento inicial varia muito entre as alternativas, com destaque para o cenário da biodigestão com concentração e uso veicular do biogás, pois, além de ser uma combinação que requer numerosos equipamentos, inclui também uma conversão e uma renovação parcial da frota para bicombustível. Com relação aos custos de operação e manutenção, os custos anuais da incineração são importantes, por incluir um concentrador de alta capacidade e uma caldeira com queimadores especiais adaptados para a operação com um combustível de baixo poder calorífico e de alto teor de cinzas.

A incineração elimina totalmente as despesas com a fertirrigação, mas os custos da operação são elevados. A alternativa seria a concentração com posterior uso fertilizante da vinhaça, dado que este sistema oferece os benefícios da redução de volume sem elevados custos operacionais, sempre e quando o calor necessário para a evaporação não dependa do consumo adicional de vapor em grandes quantidades. A biodigestão por si só não oferece nenhuma vantagem na diminuição dos custos da fertirrigação, diante disso a despesa continuaria sendo a mesma que no cenário de referência.

Tabela 50. Resultados da avaliação econômica.

\begin{tabular}{lcccc}
\hline & 1. Concentração & $\begin{array}{c}\text { 2. Biodigestão } \\
\text { + Eletricidade }\end{array}$ & $\begin{array}{c}\text { 3. Incineração + } \\
\text { Eletricidade }\end{array}$ & $\begin{array}{c}\text { 4. Biodigestão + } \\
\text { Concentração + } \\
\text { Uso veicular }\end{array}$ \\
\hline $\begin{array}{l}\text { Investimento inicial } \\
\text { Custo anual de O\&M }\end{array}$ & $\mathrm{R} \$ 3.200 .000$ & $\mathrm{R} \$ 16.690 .000$ & $\mathrm{R} \$ 22.000 .000$ & $\mathrm{R} \$ 28.500 .000$ \\
$\begin{array}{l}\text { Diminuição do custo em } \\
\text { fertirrigação }\end{array}$ & $\mathrm{R} \$ 904.000 / \mathrm{ano} / \mathrm{ano}$ & $\mathrm{R} \$ 803.136 / \mathrm{ano}$ & $\mathrm{R} \$ 2.716 .000 / \mathrm{ano}$ & $\mathrm{R} \$ 914.020 / \mathrm{ano}$ \\
$\begin{array}{l}\text { Diminuição da captação } \\
\text { de água }\end{array}$ & $\mathrm{R} \$ 0 / \mathrm{ano}$ & $\mathrm{R} \$ 0 / \mathrm{ano}$ & $\mathrm{R} \$ 913.536 / \mathrm{ano}$ & $\mathrm{R} \$ 226.000 / \mathrm{ano}$ \\
$\begin{array}{l}\text { Taxa de desconto } \\
\text { TIR }\end{array}$ & $15 \%$ & $15 \%$ & $\mathrm{R} \$ 3.840 .000 / \mathrm{ano}$ & $\mathrm{R} \$ 904.000 / \mathrm{ano}$ \\
$\begin{array}{l}\text { Preço do diesel ou da } \\
\text { eletricidade }\end{array}$ & $21 \%$ & $21 \%$ & $15 \%$ & $15 \%$ \\
$\begin{array}{l}\text { Preço da CER } \\
\text { VPL }\end{array}$ & 0 & $\mathrm{R} \$ 240 / \mathrm{MW}_{\mathrm{e}}$ & $\mathrm{R} \$ 190 / \mathrm{MW}_{\mathrm{e}}$ & $\mathrm{R} \$ 2,86 / 1$ \\
\begin{tabular}{l} 
Payback descontado \\
\hline
\end{tabular} & $\mathrm{R} \$ 1.071 .192$ & $\mathrm{R} \$ 6.872 .708$ & $\mathrm{R} \$ 7.258 .165$ & $\mathrm{R} \$ 9.402 .336$ \\
\hline
\end{tabular}

Fonte: Resumo dos indicadores financeiros contidos na Tabela 37, Tabela 41, Tabela 45 e Tabela 49. 
Os valores de Investimento inicial, Custo anual de O\&M e VPL, mostrados na Tabela 50, são representados na Figura 41.

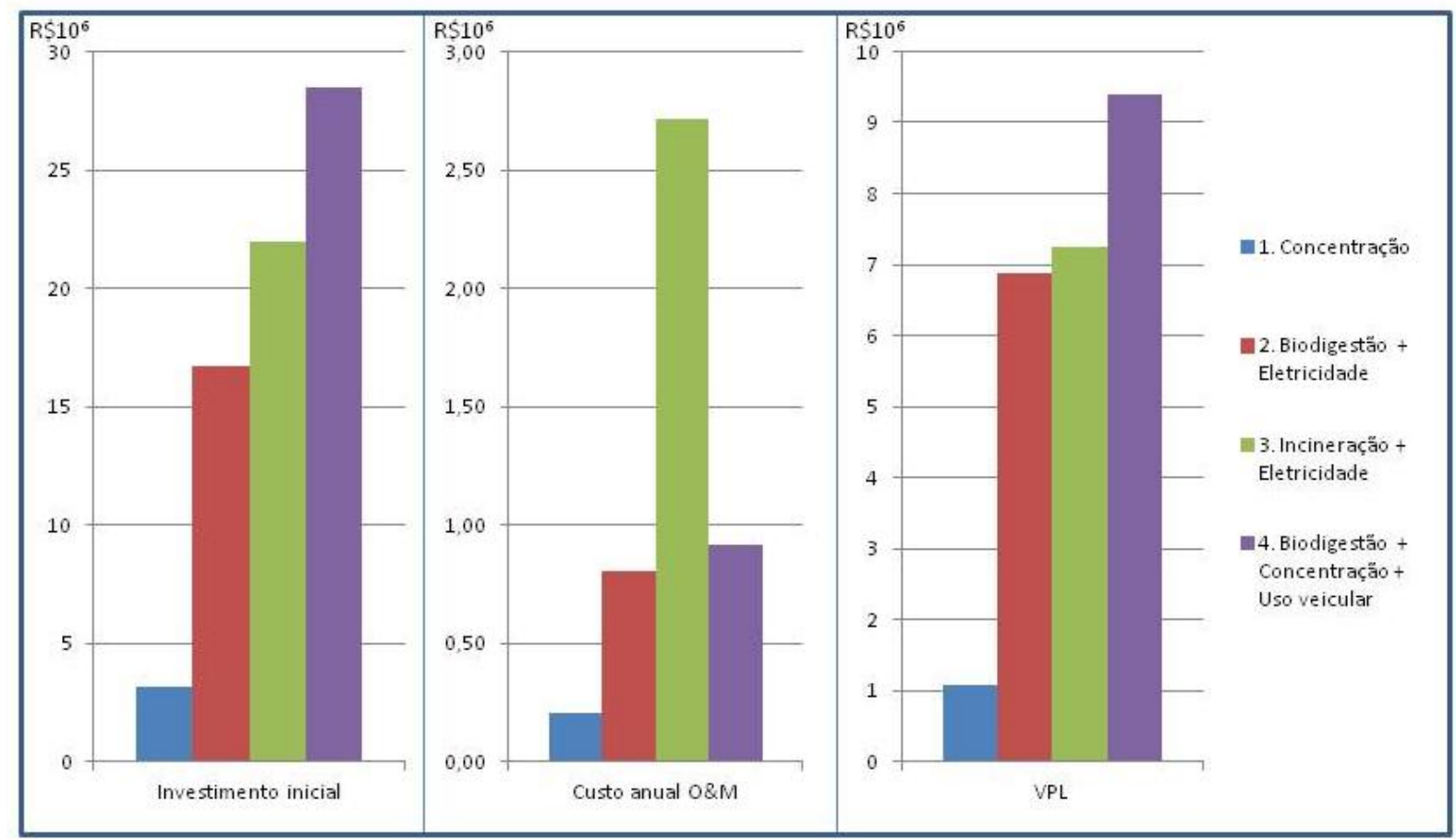

Figura 41. Investimento inicial, Custo anual O\&M e VPL (TIR = 21\%) nos diferentes cenários. Fonte Autor.

Em termos de produção e venda de energia elétrica, a biodigestão se mostrou pouco viável quando não são incorporadas medidas de eficiência na produção de biogás a partir da vinhaça. Em um cenário otimista, utilizando dados dos fabricantes de equipamentos, chegouse ao custo de produção de $\mathrm{R} \$ 240 / \mathrm{MWh}_{\mathrm{e}}$, pouco competitivo para entrar no mercado. Para obter um investimento com uma TIR $=21 \%$, seria necessário que o preço da eletricidade atingisse $\mathrm{R} \$ 240 / \mathrm{MWh}_{\mathrm{e}}$ e que o valor do CER estivesse em torno de $\mathrm{R} \$ 60 / \mathrm{tCO}_{2}$ eq. A incineração só apresenta vantagens frente à biodigestão quando contabilizada a redução de despesas na fertirrigação e na captação de água. Embutindo estes ganhos, a incineração seria viável com preços da eletricidade de $\mathrm{R} \$ 190 / \mathrm{MW}_{\mathrm{e}}$ e com o CER vendido a $\mathrm{R} \$ 40 / \mathrm{tCO} \mathrm{C}_{2} \mathrm{eq}$, valores bem inferiores aos requeridos pela biodigestão.

$\mathrm{Na}$ situação atual, a opção da produção de combustível veicular para abastecimento da própria frota aparece longe da viabilidade. Foi calculado um custo de produção do "litro de diesel equivalente" de $\mathrm{R} \$ 2,79 / 1$, superior ao encontrado atualmente na bomba para o diesel derivado do petróleo. Somente incorporando os benefícios econômicos da concentração e o pagamento pela redução de emissões de GEEs, que esta tecnologia poderia ser atrativa para o setor. 
Como conclusões deste capítulo são colocadas as seguintes afirmações:

- A concentração é viável e atrativa economicamente na situação atual, sempre e quando se aproveite o calor residual do processo da usina e não dependa de consumo de vapor adicional.

- A viabilização dos demais processos para o tratamento da vinhaça com aproveitamento energético está subordinada à valorização dos benefícios ambientais que estas tecnologias trazem. Sem o incentivo para a redução da captação de água e de emissões de GEEs, ou para a substituição de combustíveis fósseis por fontes renováveis, estas tecnologias não serão a preferência da iniciativa privada nas condições atuais. 


\section{CAPÍTULO 6. RESULTADOS E DISCUSSÃO}

Nos capítulos anteriores foi discutido o estado da arte das tecnologias para o processamento da vinhaça, o balanço energético de cada alternativa, bem como os fatores ambientais e econômicos. A seguir, os resultados dos anteriores capítulos são analisados, resumidos e discutidos, para atingir os objetivos gerais e específicos deste estudo, como passo prévio à apresentação das conclusões e considerações finais.

\subsection{Cenário 0 de referência: Fertirrigação com vinhaça in natura}

A prática da fertirrigação está amplamente estendida, pois contribui para reduzir o problema da disposição da vinhaça e para diminuir o consumo de fertilizantes. A dificuldade desta técnica se encontra nos custos do transporte, que estimulam a excessiva dosagem nos cultivos próximos à destilaria. Souza (2005) relata que a aplicação média era de 131,5 m³/ha, sendo esta dose quase o dobro da estritamente necessária para o cultivo ${ }^{58}$. Com a entrada da Norma P4.231 no ano 2006, esta dosagem praticada deve ser diminuída (CETESB, 2006), incrementando os custos na logística da fertirrigação que são atualmente da ordem de $\mathrm{R} \$ 4 / \mathrm{m}^{3}$ de vinhaça (JORNALCANA, 2007). Desse modo, apesar do valor do raio econômico de fertirrigação se encontrar próximo aos $30 \mathrm{~km}$ (ELIA NETO et al.,2008), atualmente uma parte do volume de vinhaça tem que ser transportado a distâncias superiores a $60 \mathrm{~km}$ em alguns casos (USINA VISTA ALEGRE, 2014) ${ }^{59}$. Um fator a considerar na avaliação de impacto ambiental é a grande escala de aplicação da fertirrigação, que dificulta a fiscalização do cumprimento da Norma P4.231.

O consumo de diesel no cenário atual já é importante, com 30 1/ha fertirrigada (Tabela 14), e a diminuição da dosagem indicada anteriormente tende a incrementá-lo. Todas as alternativas de tratamento oferecem uma redução na demanda deste combustível com exceção da biodigestão, que mantém o mesmo nível de despesa.

Com relação às emissões, as que são provenientes do diesel podem ser insignificantes quando comparadas às acentuadas emissões das lagoas de armazenamento e canais. Segundo Pires (informação verbal) ${ }^{60}$, estes depósitos funcionam em muitos casos como lagoas de estabilização com tempo de detenção hidráulica de alguns dias e com quedas importantes na DQO da vinhaça. Como foi levantado nos trabalhos de Oliveira (2009) e Paredes (2011), as

\footnotetext{
${ }^{58}$ A cultura de cana extrai $185 \mathrm{kgK}_{2} \mathrm{O} /$ ha ano (CETESB, 2006) e a concentração media de potássio na vinhaça é de $2,6 \mathrm{~kg} / \mathrm{m}^{3}$, portanto a dosagem deveria ser aproximar a $72 \mathrm{~m} 3 /$ ha, podendo variar com cada tipo de solo.

${ }^{59}$ Visita à Usina Vista Alegre, Itapetininga /SP, novembro de 2014.

${ }^{60}$ Informação dada pelo Prof. Dr. Eduardo Cleto Pires, durante o exame de qualificação da presente dissertação, São Paulo, agosto de 2014
} 
principais emissões de GEEs se produzem em forma de $\mathrm{CH}_{4}$. Nos resultados obtidos no presente estudo, observa-se que aproximadamente $7 \%$ do carbono contido na vinhaça é emitido em forma de $\mathrm{CH}_{4}$, sendo significativamente superior ao valor de $0,2 \%$ utilizado por Soares et al. (2009) no cálculo do balanço de emissões de GEEs do uso de etanol da cana-deaçúcar. Ainda assim, este valor é conservador se comparado com o valor de $33 \%$ observado por Paredes, 2011. Observe-se que Macedo et al. (2008) consideram que a vinhaça não permanece em lagoas e assumem que as emissões de metano não são significativas.

$\mathrm{O}$ assunto, como visto aqui, não tem unanimidade nos diferentes estudos consultados e gera controvérsias. No relatório da CETESB sobre emissões do setor de resíduos sólidos e efluentes líquidos no Estado de São Paulo (CETESB, 2013), considera-se que as emissões de $\mathrm{CH}_{4}$ pelo manejo de efluentes industriais no setor sucroalcooleiro são nulas. Neste mesmo relatório, indica-se que, em 2008, o manejo de efluentes em todo o setor industrial foi responsável pela emissão de aproximadamente 1,5 milhões de $\mathrm{tCO}_{2}$ eq. Portanto, se fosse incluída a emissão de lagoas e canais de vinhaça estimada no presente trabalho a partir dos estudos citados ${ }^{61}$, a emissão de GEEs dos efluentes industriais no Estado de São Paulo seria multiplicada por 3 , sendo que o setor sucroalcooleiro seria responsável por $2 / 3$ das emissões. Em 2010, foram emitidas 12,6 milhões de $\mathrm{tCO}_{2}$ eq pelo tratamento de resíduos no Estado de São Paulo, incluindo a disposição de resíduos sólidos urbanos em aterros, a incineração de resíduos, o tratamento de efluentes domésticos e industriais (CETESB, 2013). Se fosse confirmada a ordem de magnitude das emissões de vinhaça, este número seria incrementado em aproximadamente 24\%. Pretende-se, portanto, continuar esta analise em estudos posteriores de forma a se obter resultados mais confiáveis para o Estado de São Paulo.

As emissões de $\mathrm{CH}_{4}$ em lagoas e canais dependem, em grande parte, das dimensões, da geometria e do revestimento destas estruturas (PAREDES, 2011), assim como do teor de matéria orgânica contido na vinhaça, que varia em amplos intervalos ao longo da safra. A metodologia ACM0014 "Treatment of wastewater" utilizada para estimar as emissões da lagoa neste estudo, tem como condição para sua aplicação a existência de períodos de retenção na escala de meses. Atualmente, a tendência é construir lagoas de armazenamento menores, para controlar o risco de acidentes ambientais como a quebra de barragens destes reservatórios. Por isto, o tempo de retenção nas lagoas são da ordem de dias. O tempo de retenção da vinhaça nas lagoas é um dado importante para conhecer sua emissão de $\mathrm{CH}_{4}$, o

\footnotetext{
${ }^{61}$ BODDEY, 2009; OLIVEIRA, 2010; PAREDES, 2011.
} 
que indica a necessidade de que aprofundem a realidade dimensional e de gestão destes reservatórios.

Considerando o exposto anteriormente, medidas como a obrigatoriedade no revestimento de lagoas e canais mestres, a diminuição do tempo de retenção nas lagoas evitando o "envelhecimento" da vinhaça nas mesmas, assim como a limpeza do lodo formado no fundo de lagoas e canais, permitiriam mitigar as emissões de $\mathrm{CH}_{4}$ deste cenário. Outra possibilidade seria cobrir as lagoas com lonas e aproveitar o biogás ou, simplesmente, queimar em flare.

Cabe mencionar que, na maioria dos casos, a cana-de-açúcar é usada para produção de açúcar e álcool em proporção variável. Portanto, os impactos que produz a fertirrigação não devem ser exclusivamente alocados no etanol.

\subsection{Cenário 1: Concentração evaporativa}

A implantação de concentradores implica em uma redução no consumo de diesel de $25 \%$ com relação ao Cenário 0, sendo importante para o balanço energético e econômico do etanol. Devido à economia produzida na logística da fertirrigação, a implantação de concentradores tem um retorno financeiro interessante (Payback Descontado de 9 anos e TIR 21\%). A facilidade na dispersão do potássio e, portanto, no cumprimento da Norma P4.231 sem elevar as despesas em fertirrigação, explica em alguns casos a instalação desta tecnologia.

Outro fator importante pelo qual várias usinas adotaram a concentração é a queda na necessidade do uso de vapor com a introdução do aproveitamento do calor residual do processo. O uso da energia do vapor do álcool proveniente das colunas de destilação é um fator fundamental para a viabilidade econômica da concentração. Com a finalidade de incrementar as possibilidades de aplicação desta tecnologia, estão sendo desenvolvidas novas fontes de energia, como, por exemplo, o uso do calor dos gases de exaustão das caldeiras.

O consumo de energia elétrica no concentrador não parece ser um fator determinante, devido ao fato de que estes equipamentos precisam, fundamentalmente, de uma grande quantidade de energia térmica.

O uso de concentradores com condensador possibilita a reutilização da água na produção do álcool, diminuindo o consumo da usina. Porém, esta técnica pode implicar uma maior circulação de caminhões-tanque no interior dos cultivos, com potenciais consequências sobre a compactação do solo. 
Neste cenário existe uma redução significativa das emissões de GEEs, considerando que a vinhaça concentrada e transportada em caminhão não tem emissão de $\mathrm{CH}_{4}$. Desta forma, a mitigação é praticamente equivalente à porcentagem de volume destinada à concentração. Porém, se os estudos citados ${ }^{62}$ se confirmarem, isso indicará que grande parte da emissão de $\mathrm{CH}_{4}$ em lagoas e canais permaneceria inalterada com respeito ao Cenário 0 , pois continuaria a ser transportado por eles a maior fração do volume de vinhaça. Com a redução do consumo de diesel também são mitigadas emissões de GEEs, mas esta diminuição não é relevante quando comparada com a estimada nas lagoas.

Observa-se que não foi possível acessar dados empíricos sobre as emissões produzidas no solo da lavoura quando é aplicada vinhaça concentrada.

\subsection{Cenário 2: Biodigestão anaeróbia com geração de eletricidade}

Um dos problemas da biodigestão é que ela não diminui o volume de vinhaça, o que significa que os custos operacionais e o consumo de combustível na fertirrigação continuam sendo os mesmos do Cenário 0.

Durante a biodigestão, o conteúdo de potássio, fósforo e nitrogênio são mantidos, conservando as propriedades fertilizantes da vinhaça. Isto também significa que, para se adequar à Norma P4.231, os custos de dispersão do potássio permanecem. Por outro lado, em determinados tipos de solos, pode ser considerado que a eliminação da matéria orgânica produzida com a biodigestão é uma perda de seu potencial de fertilização.

A produção de eletricidade é fortemente influenciada pela eficiência no processo de conversão da matéria orgânica em biogás, que se produz durante a biodigestão. Foram utilizados, em um primeiro cálculo, valores conservadores baseados na experiência do biodigestor da Usina São Marinho, instalação com maior tempo de funcionamento no país. Neste caso, a baixa eficiência da biodigestão na produção de biogás permite a instalação de apenas $1 \mathrm{MW}_{\mathrm{e}}$. Contando com a melhoria na eficiência (que podem trazer os reatores IC) e com um melhor controle da operação, a potência instalada poderia ser triplicada (Tabela 40).

De qualquer modo, a eletricidade produzida a partir do biogás capturado não tem um impacto importante na redução de emissões, fundamentalmente devido às características da matriz elétrica brasileira, com 76,9\% de produção hidroelétrica (BEN, 2013), pois foi considerado que a eletricidade produzida é destinada ao sistema interligado. Observa-se que o

\footnotetext{
${ }^{62}$ BODDEY, 2009; OLIVEIRA, 2010; PAREDES, 2011.
} 
resultado seria mais vantajoso se esta usina estivesse em uma região onde a geração de energia fosse de outra origem (e não do SIN) como, por exemplo, termelétricas a óleo diesel.

Um possível obstáculo para a implantação da tecnologia da biodigestão é quando ocorre o uso de antibióticos termoestáveis na fermentação, pois os mesmos continuam ativos na vinhaça depois do processo de destilação. Consequentemente, estes compostos ativos afetam a atividade dos microrganismos associados à metanogênese que se encontram no biodigestor. Além de ser um problema para a biodigestão, o uso de antibióticos gera uma barreira comercial para a exportação do etanol e das leveduras (vendidas como ração animal), pois na União Européia, potencial importador, não são aceitos o uso destes agentes na fabricação.

Para vencer a barreira do uso de antibióticos, existem diversas alternativas para o controle da infecção nas dornas, submetendo o caldo a tratamento com ozônio, raios gama e ultravioleta. As três opções anteriores são inviáveis atualmente pelo alto custo econômico. Outras opções mais viáveis economicamente são:

a) Pasteurização do mosto (caldo), recuperando o calor da vinhaça;

b) leveduras modificadas para combater a infecção, porém competitivas com as demais para o desdobramento do açúcar;

c) antibióticos termolábeis;

d) produtos que atuam como antibióticos e não interferem nos processos de biodigestão;

e) uma combinação das opções anteriores.

Neste sentido, são observados avanços na procura de alternativas, como, por exemplo, os tratamentos físicos desenvolvidos por Nolasco (2010).

Embora estas tecnologias estejam disponíveis, os antibióticos termostáveis continuam sendo a opção mais econômica para os produtores de etanol. Um fator que poderia inverter este quadro seria a criação de uma legislação específica que penalizasse economicamente o uso destas substâncias, mas esta medida afetaria diretamente o setor. Outra possibilidade seria destinar parte das remessas obtidas com a venda de energia elétrica, produzida a partir do biogás da vinhaça, para cobrir a diferença do preço existente entre os antibióticos termoláveis - mais custosos -, e os tradicionais.

Com relação às emissões, a remoção da matéria orgânica presente na vinhaça, por meio da biodigestão, evita as emissões de $\mathrm{CH}_{4}$ em lagoas e canais. Apesar disso, atualmente não existe um incentivo para a mitigação de GEEs. Um efeito colateral benéfico deste tratamento 
é a eliminação do odor característico da vinhaça nos campos, que é produzido pela decomposição da matéria orgânica.

Embora tenha sido demonstrada a viabilidade técnica da digestão anaeróbia da vinhaça, os fatores econômicos continuam sendo um grande obstáculo. Até o momento tem sido evidenciado que os valores oferecidos pelo mercado do setor elétrico ou por programas de incentivo como o PROINFA ${ }^{63}$ não são atrativos para os investidores. Os biodigestores necessários devem possuir dimensões de grande tamanho para tratar o elevado volume manejado e para permitir longo tempo de retenção. Devido a isto, o ganho com a venda de energia elétrica produzida utilizando biogás não compensa o substancial investimento inicial. Como foi exposto no Capítulo 5 de avaliação econômica, esta tecnologia não está muito longe da viabilidade econômica, mas, para isso, seria necessário tanto o estabelecimento do preço pago pela eletricidade no valor de R $\$ 240 / \mathrm{MWh}$ como a existência de um mercado de carbono registrando valores da ordem de $\mathrm{R} \$ 60 / \mathrm{tCO}_{2} \mathrm{eq}$, tudo isso para fazer o investimento atrativo.

\subsection{Cenário 3: Incineração com geração de eletricidade}

Como foi calculado no Capítulo 3, existe um equilíbrio entre a energia consumida para a concentração da vinhaça e a obtida na sua incineração, de modo que o balanço energético não seria uma barreira. Por outro lado, neste cenário é exportado quase o dobro da quantidade de energia elétrica se comparado ao Cenário 2.

O Cenário 3 apresenta o maior consumo de combustível de origem fóssil, uma vez que é necessário gás natural para a combustão completa da vinhaça, o que afeta negativamente o balanço energético do etanol. Para evitar este impacto, deve ser considerada a utilização de outros combustíveis suporte de origem renovável, e que estejam disponíveis para a usina, como a palha ou o bagaço. Porem, não são encontrados no mercado equipamentos capazes de picar palha ou bagaço nas quantidades necessárias por unidade de tempo e com a granulometria requerida (menos de $1 \mathrm{~mm}$ ) pelo queimador torsional que realiza a incineração conjunta com a vinhaça. Também existem problemas técnicos com o volume de cinzas que gera a combustão de vinhaça, exigindo caldeiras com numerosos sopradores de fuligem, encarecendo a instalação e a operação. Se fosse incinerada junto com o bagaço ou, principalmente, com a palha, o problema das cinzas aumentaria significativamente. Além disso, é de vital importância para a caldeira garantir a combustão completa da vinhaça, visto

\footnotetext{
${ }^{63}$ O Programa de Incentivo às Fontes Alternativas de Energia Elétrica (PROINFA), conforme descrito no Decreto $\mathrm{n}^{\circ} 5.025$, de 2004, foi instituído com o objetivo de aumentar a participação da energia elétrica produzida por empreendimentos concebidos com base em fonte eólica, biomassa e pequenas centrais hidrelétricas no SIN.
} 
que, por sua acidez, sua queima inadequada produziria graves problemas de corrosão (SAACKE, 2013).

Como vantagens ambientais do Cenário 3, destaca-se a completa eliminação dos impactos negativos devidos à fertirrigação, já que elimina totalmente o volume de vinhaça. Outras vantagens são a recuperação quase completa da água da vinhaça e a total eliminação dos antibióticos ativos que se encontram presentes.

Com relação às emissões, neste cenário obteve-se uma redução de emissões similar ao cenário anterior, visto que todo o carbono orgânico presente na vinhaça é convertido em $\mathrm{CO}_{2}$, fechando o ciclo do carbono fixado previamente pela cana. Entretanto, os principais impactos negativos do Cenário 3 são os inerentes a um sistema de incineração que utiliza combustível com baixo poder calorífico e elevada quantidade de nitrogênio e enxofre, produzindo possíveis emissões de $\mathrm{NO}_{\mathrm{x}}, \mathrm{SO}_{\mathrm{x}}$ e micropartículas, além do $\mathrm{CO}_{2}$ proveniente do gás natural. Com exceção do $\mathrm{CO}_{2}$, estes poluentes podem ser eliminados, quase na sua totalidade, com uma boa regulação da combustão e do tratamento dos gases de exaustão, entretanto, os equipamentos necessários impactam tanto no investimento como nos custos de operação.

O investimento na planta de incineração de vinhaça é elevado, assim como os custos de operação e de manutenção, que são os maiores entre os cenários avaliados (Tabela 50). Como no caso anterior, a viabilidade econômica depende da valorização dos serviços ambientais, tais como a recuperação da água, a mitigação de GEEs e o aproveitamento da vinhaça como fonte renovável de energia elétrica.

Um problema econômico a ser analisado caso a caso é o do transporte do gás natural necessário, considerando a localização isolada da rede de distribuição da maioria das usinas.

\subsection{Cenário 4: Biodigestão com concentração e uso veicular}

A concentração e a biodigestão são tratamentos que, separadamente, melhoram o aproveitamento da vinhaça, mas a sua combinação agrega essas vantagens, podendo criar efeitos sinérgicos. Um sistema que primeiro realize a biodigestão para depois concentrar a vinhaça eliminaria a carga orgânica, facilitando a operação dos concentradores. Já que a vinhaça biodigerida é menos corrosiva, por ter um $\mathrm{pH}$ mais elevado que a vinhaça in natura, estima-se um aumento da durabilidade das bombas e dos equipamentos empregados na concentração e na distribuição. Com o biogás produzido, pode-se suprir o consumo elétrico das cargas internas do biodigestor e do concentrador, assim como também as da limpeza, as da purificação e as da compressão do biogás. O biometano obtido pode abastecer a frota 
empregada na lavoura e, também, o transporte de cana. Ainda, contando com as infraestruturas necessárias, o biometano pode ser injetado na rede de gás natural como alternativa ao uso veicular.

O Cenário 4 é o que apresenta maior redução do uso de combustíveis fósseis, sendo a opção mais vantajosa para melhorar o balanço energético do etanol. Os dados utilizados apontam que o biometano procedente da biodigestão da vinhaça poderia reduzir em $50 \%$ o consumo de diesel da agroindústria (MORENO \& COELHO, 2014).

Como mostrado no balanço energético, a substituição parcial de diesel por biometano na frota destinada à fertirrigação, só requereria $15 \%$ do biogás produzido. Dessa forma, o restante poderia ser utilizado em outras operações do cultivo da cana-de-açúcar. Foi documentada uma experiência, na Usina São João, de uso veicular do biometano procedente da vinhaça; este projeto foi desativado pela queda no preço do diesel e pelos problemas do biometano nos motores de alta potência, que são utilizados nos treminhões que transportam a cana-de-açúcar, atividade responsável pela maior parte do consumo de diesel na usina (SOARES, 2009).

Não foi encontrado disponível no mercado um kit de conversão para adaptar os motores dos treminhões em uso, o que implica na renovação da frota para passá-la a bicombustível. Segundo Nigro (informação verbal) ${ }^{64}$, no Brasil encontram-se fabricantes que têm desenvolvido motores de elevadas potências para funcionamento com Gás Natural Veicular (GNV), mas a falta de procura faz com que não existam linhas de fabricação. Observa-se que a tecnologia bicombustível (diesel - gás natural), para o transporte de carga, tem surgido com força nos Estados Unidos nos últimos anos. Este fato se deve à diminuição dos preços do gás natural que a exploração do gás de xisto tem trazido. Por essa razão, no mercado externo, temse disponível para compra cavalos mecânicos bicombustível nas potências requeridas pelo setor sucroalcooleiro, o que não se encontra (ainda) no Brasil.

Da mesma forma que no Cenário 2, que também inclui biodigestão, é importante a eliminação dos antibióticos termoestáveis do processo de fermentação alcoólica para permitir uma eficiência adequada. Os custos com a implantação da sua alternativa podem ser compensados com a economia obtida na substituição do diesel.

Nota-se que este é o cenário com maior investimento inicial, uma vez que agrupa a implantação do biodigestor, do concentrador e da planta de acondicionamento e de compressão do biogás para uso veicular, assim como a conversão da frota para bicombustível.

\footnotetext{
${ }^{64}$ Informação dada pelo Prof. Dr. Francisco Emilio Baccaro Nigro, durante o evento "São Paulo Advanced School on the Present and Future of BIOENERGY”, Campinas/SP, outubro de 2014.
} 
Todos os problemas técnicos, tanto da biodigestão como do uso veicular, são salváveis com o estado atual do conhecimento, sendo o fator econômico a principal barreira existente para que este sistema não esteja presente das usinas.

Como foi calculado no Capítulo 5, o preço atual de produção do "litro de diesel equivalente" ${ }^{\text {, }}$, a partir de vinhaça, é muito similar ao do diesel fóssil encontrado nas bombas. Consequentemente, não existe incentivo para sua substituição. Diante da perspectiva de exploração das reservas de petróleo encontradas no pré-sal, observa-se uma expectativa de que os preços do diesel se mantenham baixos. Em virtude disso, nota-se que a vontade política de investimentos no setor da energia está voltada, atualmente, para a exploração destes recursos não renováveis.

A ausência de incentivo à mitigação de emissões, com a desvalorização do crédito de carbono, e o escasso conhecimento sobre a verdadeira magnitude das emissões de $\mathrm{CH}_{4}$ nos sistemas de distribuição de vinhaça, bem como os preços baixos do diesel, fazem este sistema de tratamento ser de escasso interesse para os investidores.

\footnotetext{
${ }^{65}$ Quantidade de biometano capaz de fornecer a mesma energia térmica que um litro de diesel.
} 


\section{CAPÍTULO 7. CONCLUSÕES}

A vinhaça é o principal subproduto da produção de etanol e, no Brasil, são gerados aproximadamente 250 milhões de $\mathrm{m}^{3}$ de vinhaça por safra. Este efluente possui grande quantidade de matéria orgânica e de sais, sendo que seu uso em fertirrigação pode ser causa de impactos ambientais no solo e na água, assim como de emissões de GEEs.

O objetivo geral deste estudo é comparar as diferentes alternativas para o aproveitamento energético da vinhaça, na procura daquelas com maior viabilidade tecnológica, com reduzido impacto ambiental e que estejam associadas a um menor custo. Para isto, foram configurados cinco cenários que representam as tecnologias mais estudadas atualmente. Como cenário de referência foi estabelecido a fertirrigação com vinhaça in natura e, como suas alternativas, consideraram-se a concentração, a biodigestão e a incineração com produção de energia elétrica, bem como a combinação da biodigestão com a concentração e com o uso veicular do biogás.

Verificou-se a hipótese de que existem tecnologias disponíveis que melhoram o desempenho ambiental da gestão do resíduo e, ao mesmo tempo, permitem um melhor aproveitamento da vinhaça e uma economia de energia. Entretanto, com as premissas adotadas neste estudo, a única tecnologia avaliada que se mostra viável economicamente na situação atual é o sistema de concentração.

Com os valores assumidos neste estudo, verifica-se que a biodigestão, a incineração com produção de eletricidade, e o uso veicular do biogás de vinhaça, estão atualmente próximos da viabilidade econômica, sem chegar a atingi-la. Porém, com o elevado número de variáveis e de considerações incluídas na avaliação, esta afirmação deve ser revista em cada caso particular.

Com relação à redução de emissões, os primeiros estudos (BODDEY, 2009; OLIVEIRA, 2010; PAREDES, 2011) mostram evidências de que, em lagoas e canais utilizados na fertirrigação, uma porcentagem significativa do carbono contido na vinhaça é emitida na forma de $\mathrm{CH}_{4}$. Tanto a biodigestão como a incineração apresentam-se interessantes para reduzir essas potenciais emissões de GEEs na fertirrigação, mas a incineração requer uma quantidade significativa de gás natural, o que incrementaria a energia fóssil utilizada para produzir etanol.

A possibilidade de usar o biogás como combustível veicular é mais conveniente que seu emprego na geração de eletricidade, visto que a substituição do diesel melhora com mais intensidade o balanço energético do etanol de cana-de-açúcar. 
Devido ao significativo potencial que possui a vinhaça como fonte de geração de energia, recomenda-se dar continuidade nas pesquisas visando vencer as dificuldades atuais na viabilização econômica destas técnicas. Além disso, com a introdução de medidas que premiem monetariamente os serviços ambientais -tais como a mitigação de emissões de GEEs, a redução do consumo de água e a produção de energia a partir de fontes renováveisseria alcançada uma atratividade aceitável nos investimentos para o processamento da vinhaça.

A combinação da biodigestão com a concentração é a alternativa que reúne o maior número de vantagens com respeito ao cenário da fertirrigação com vinhaça in natura, sendo enumeradas a seguir as mais importantes:

a) Diminui o volume da vinhaça, facilitando sua distribuição a longas distâncias, de forma a evitar a concentração de nutrientes no entorno das usinas e a favorecer o cumprimento da Norma P4.231;

b) incentiva a substituição de antibióticos termoestáveis por técnicas menos perigosas para o meio ambiente, sendo fundamental que a vinhaça in natura não contenha antibióticos ativos que prejudiquem a produção de biogás;

c) elimina emissões de $\mathrm{CH}_{4}$ na atmosfera e o odor nos campos de cana produzidos pela decomposição da vinhaça;

d) possibilita a reutilização da água na usina e, assim, diminui a captação para a produção do álcool;

e) reduz a aplicação de adubos minerais, pois em determinadas circunstancias, pode reduzir a lixiviação de nutrientes,

f) reduz o risco de vazamentos em lagoas e canais, permitindo um melhor controle e aproveitamento da vinhaça como fertilizante,

g) permite substituir combustíveis fósseis por biogás, evitando emissões de $\mathrm{CO}_{2}$ e a depleção de recursos não renováveis na produção de etanol;

h) produz eletricidade para suprir a própria demanda de energia do sistema de tratamento.

O presente estudo não esgota as possibilidades de tratamento e de processamento da vinhaça, pois existem tecnologias que não foram incluídas por estarem em fase incipiente de desenvolvimento. Como exemplos de técnicas que podem ser alvo de futuros estudos, encontram-se a biodigestão em duas fases com produção de hidrogênio e a concentração por microfiltração. 
Por outro lado, não foram avaliados todos os usos do biogás de vinhaça, sendo necessários estudos que avaliem outras possibilidades, tais como a injeção de biometano na rede de gás natural e, em áreas fora do alcance desta rede, a substituição de GLP doméstico ou o uso como fonte energética para a indústria local.

Os resultados desta dissertação foram limitados pela carência de estudos sistemáticos que avaliem o impacto da fertirrigação com vinhaça na qualidade do solo e das águas subterrâneas. Igualmente, pela falta de referências encontradas, tampouco foi possível estimar o potencial impacto da dispersão de antibióticos no meio ambiente.

Por causa da ausência de monitoramento das emissões de GEEs nos sistemas de distribuição de vinhaça e da sua exclusão nos inventários de emissões publicados, no presente estudo, as estimativas realizadas foram baseadas em dados bibliográficos produzidos com medições pontuais. Por esta razão, seriam necessárias amostragens sistemáticas para produzir resultados com comprovada representatividade.

Por todo o anterior, conclui-se que são necessárias mais pesquisas sobre os impactos da fertirrigação com vinhaça in natura e sobre as possibilidades do aproveitamento energético deste coproduto da produção de etanol. 


\section{REFERÊNCIAS BIBLIOGRAFICAS}

ABNT - ASSOCIAÇÃO BRASILEIRA DE NORMAS TÉCNICAS, RESÍDUOS SÓLIDOS - Classificação, ABNT NBR 10.004, 2004.

ALMEIDA, JR.; RANZANI, G.; VALSECCHI, O. La vinassi dans lagriculture. Boletim do Instituto Zimonecnico. Piracicaba, n. 3, p. 1-9, 1950.

ANA - AGÊNCIA NACIONAL DE ÁGUAS. Manual de conservação e reúso de água na agroindústria sucroenergética. Ministério do Meio Ambiente. Brasília, 2009.

ANEEL- AGÊNCIA NACIONAL DE ENERGIA ELÉTRICA. Banco de informações de geração (BIG). Disponível em:

<http://www.aneel.gov.br/aplicacoes/capacidadebrasil/capacidadebrasil.cfm>. Acesso em: 16 jun 2012.

AVRAM, P.; MORGENROTH, B.; SEEMAN, F., Vision paper for improving the utilization of bagasse and vinasse in the sugar \& ethanol industry. In: Workshop of Co217 Products International Society of Sugar Cane Technologists, Maceió, Alagoas, 2006. Proceedings do ISSCT Co-Products Workshop. Proceedings in CD, Maceio, 12-16 of November, 2006.

BARBERI, M. C., Análise do Uso e das Possibilidades do Gás Metano Fóssil e de Biodigestão nas Frotas de Veículos em São Paulo e Outras Regiões, nos Anos 90, Dissertação Mestrado, Universidade de Campinas, Campinas, 1998.

BARROS, R. P., VIÉGAS, P. R. A., SILVA, T. L., SOUZA, R. M., BARBOSA, L., VIÉGAS, R. A., MELO, A. S. Alterações em atributos químicos de solo cultivado com canade-açúcar e adição de vinhaça. Pesquisa Agropecuária Tropical, 40(3), 341-346, 2010.

BIASE, L. P. Aspectos Gerais da concentração das vinhaças. In: II WORKSHOP DE GESTÃO DE ENERGIA E RESÍDUOS NA AGROINDÚSTRIA SUCROALCOOLEIRA, 2007, Pirassununga. Anais. Pirassununga: Faculdade de Zootecnia e Engenharia de Alimentos, USP, 2007.

BNDES - BANCO NACIONAL DO DESENVOLVIMENTO. Bioetanol de cana-deaçúcar : energia para o desenvolvimento sustentável. Rio de Janeiro, 2008.

BODDEY, R. M., Greenhouse Gas Emission in the Production Cycle of Bioethanol from sugarcane, Embrapa Agrobiologia, Seropedica, RJ, 2009.

BEN, Balanço Energético Nacional 2005, Empresa de Pesquisa Energética - EPE, Ministério de Minas e Energia - MME, 2006.

BEN, Balanço Energético Nacional 2012, Empresa de Pesquisa Energética - EPE, Ministério de Minas e Energia - MME, 2013.

BRASIL. Portaria MINTER n 323 de 29/11/1978. Proíbe o lançamento, direto ou indireto, do vinhoto em qualquer coleção hídrica, pelas destilarias de álcool. 29 de novembro de 1978. 
BRASMETANO. Oportunidades do biogás da vinhaça. In: $3^{\circ}$ SEMINÁRIO BIOENERGIA: DESAFIOS E OPORTUNIDADES DE NEGÓCIOS. Utilização de Resíduos Urbanos e Rurais como Fonte de Energia. São Paulo, 24 novembro de 2011

CEC - CALIFORNIA ENERGY COMMISSION. Dairy Power Production Program. Dairy Methane Digester System Program Evaluation Report. Marsh, M. L. H., Officer, C. E., Schiffler, K., \& Coordinator, G. (February). 2009.

CAMPOS, M.P. Produção de Biogás por Digestão Anaeróbia do Vinhoto, 1a Parte. Brasil Açucareiro, vol. 98, nº1, p.47-53, jul/1981.

CAPANA, G.H. estudo de impacto do enxofre presente no diesel na emissão de poluentes e em tecnologia de pós-tratamento de gases de escape. Dissertação (Mestre Profissional em Engenharia Automotiva) - Escola Politécnica, Universidade de São Paulo, São Paulo, 2008.

CARMO, J. B. DO, FILOSO, S., ZOTELLI, L. C., DE SOUSA NETO, E. R., PITOMBO, L. M., DUARTE-NETO, P. J., MARTINELLI, L. A., Infield greenhouse gas emissions from sugarcane soils in Brazil: effects from synthetic and organic fertilizer application and crop trash accumulation, GCB Bioenergy, 5(3), 267-280, 2013.

CARVALHO, T. C. DE, SILVA, C. L.. REDUÇÃO DO VOLUME DE VINHAÇA ATRAVÉS DA EVAPORAÇÃO. In: IV SEMINÁRIO DA PÓS-GRADUAÇÃO EM ENGENHARIA MECÂNICA (Vol. D). Bauru, 2008.

CETESB - Companhia de Tecnologia de Saneamento Ambiental do Estado de São Paulo, Norma P4.231 / VINHAÇA - CRITÉRIOS E PROCEDIMENTOS, São Paulo, dez/2006.

CETESB - Companhia de Tecnologia de Saneamento Ambiental do Estado de São Paulo, Utilização de restilo como fertilizante em solos cultivados com cana de açúcar: relatório final, 262p, Imprensa São Paulo, 1982.

CETESB. Emissões do setor de resíduos sólidos e efluentes líquidos, 1990 a 2008 : relatório de referência [recurso eletrônico]/CETESB; coordenação João Wagner Silva Alves, Josilene Ticianelli Vannuzini Ferrer; equipe Calvin Stefan Iost.[et al.]. São Paulo, 2013.b.148 p. : il. color.

CETESB. Qualidade das águas subterrâneas do estado de São Paulo 2010-2012 [recurso eletrônico]/CETESB; Equipe técnica Rosângela Pacini Modesto.[et al.]. São Paulo, 2013a.

CGEE - CENTRO DE GESTÃO DE ESTUDOS ESTRATÉGICOS. Estudo sobre as possibilidades e impactos da produção de grandes quantidades de etanol visando à substituição parcial de gasolina no mundo - Fase 1. Campinas: Nipe/Unicamp e Centro de Gestão de Estudos Estratégicos, 2005.

CHAUDHARI, P.K., MISHRA, I.M. AND CHAND, S. Effluent treatment for alcohol distillery: Catalytic thermal pretreatment (catalytic thermolysis) with energy recovery. Chemical Engineering Journal, 136: 14-24, 2008.

CLNSA - Compañía Licorera de Nicaragua, S.A. Project 0675: Vinasse Anaerobic Treatment Monitoring Report — Version 1.0, September 30th, 2009. 
COELHO, M. B, PEIXOTO, M. J. C., Considerações econômicas sobre aplicação da vinhaça por aspersão em cana-de-açúcar. In: CONGRESSO NACIONAL DA STAB, 1986, Rio de Janeiro, 1986.

COELHO, S. T.; MARTINS, O. S.; ABREU, F. C. D. A conversão da fonte renovável biogás em energia. Políticas públicas para a Energia: In: V CONGRESSO BRASILEIRO DE PLANEJAMENTO ENERGÉTICO. Desafios para o próximo quadriênio. Brasília/DF. 31 de maio a 02 de junho de 2006.

COELHO, S.T., VELAZQUEZ, S.M. S.G, SILVA, O.C. et al., Programa de uso racional de energia e fontes alternativas: PUREFA. In: ENCONTRO DE ENERGIA NO MEIO RURAL, Anais. 5., Campinas, 2004. Disponível em:

$<$ http://www.proceedings.scielo.br/scielo.php?script=sci_arttext\&pid=MSC00000000220040 00200039\&lng=en\&nrm=abn>. Acesso em: 21 Jun 2014.

CONAB - COMPANHIA NACIONAL DE ABASTECIMENTO. Perfil do Setor do Açúcar e do Álcool no Brasil, safra 2009/2010. Diretoria de Política Agrícola e Informações. Superintendência de Informações do Agronegócio, 2012.

CONAMA - CONSELHO NACIONAL DO MEIO AMBIENTE. Resolução CONAMA N ${ }^{\circ}$ 002, de 5 de junho de 1984, Boletim de Serviço n⿳0 921, de 20/7/84, do Ministério do Interior, 1984.

CONAMA, - CONSELHO NACIONAL DO MEIO AMBIENTE. Resolução CONAMA N 382, de 26 de dezembro de 2006. Estabelece os limites máximos de emissão de poluentes atmosféricos para fontes fixas. Publicação DOU no 1, de 02/01/2007, pág. 131.

COPAM - CONSELHO ESTADUAL DE POLÍTICA AMBIENTAL, Secretaria de Estado de Meio Ambiente e Desenvolvimento Sustentável, Deliberação Normativa n. ${ }^{\circ}$ 012/86, Diário do Executivo, Minas Gerais, 1986.

COPAM - CONSELHO ESTADUAL DE POLÍTICA AMBIENTAL, Secretaria de Estado de Meio Ambiente e Desenvolvimento Sustentável Deliberação Normativa $n^{\circ} 164$, de 30 de março de 2011. Estabelece normas complementares para usinas de açúcar e destilarias de álcool, referentes ao armazenamento e aplicação de vinhaça e águas residuárias no solo agrícola. Diário do Executivo, Minas Gerais, 12/04/2011)

CORAZZA, R.I. Impactos ambientais da vinhaça: controvérsias científicas e lock-in na fertirrigação?. In XLIV CONGRESSO DA SOBER “Questões Agrárias, Educação no Campo e Desenvolvimento" (pp. 1-16). Ceará, 2006.

CORTEZ, L.A.B. FREIRE, W.J. ROSILLO-CALLE, F., Biodigestion of Vinasse in Brazil. International Sugar Journal, vol.100, nº1196, 1998.

CORTEZ, L.A.B., BROSSARD PÉREZ, L.E., Experiences on vinasse disposal: part iii: combustion of vinasse -\# 6 fuel oil emulsions. Brazilian Journal of Chemical Engineering,14(1),1997.

CRUZ, L. F. L. S. Viabilidade técnica/econômica/ambiental das atuais formas de aproveitamento da vinhaça para o Setor Sucroenergético do Estado de São Paulo. 2011. 
Dissertação (Mestrado) - Escola de Engenharia de São Carlos, Universidade de São Paulo, São Carlos, 2011.

DATAGRO. Banco de dados 2012. Disponível em: <http://www.datagro.com.br/>. Acesso em: 20 jun 2013.

DUBEY, R.S. Distillery Effluents-Treatment and Disposal. Sugar News Ann. Number 6, pp. 9-26, 1974.

ELETROBRÁS. Manual de Pequenas Centrais Termoelétricas, 2 vol., Rio de Janeiro, 1985.

ELETROBRÁS. Inventário de emissões de gases de efeito estufa, ano base 2011. Junho de 2012.

ELIA NETO, A \& NAKAHODO, T., Caracterização físico-química da vinhaça- projeto $n^{\circ}$ 9500278. Relatório Técnico da Seção de Tecnologia de Tratamento de Águas do Centro de Tecnologia Copersucar, 26p, Piracicaba, 1995.

ELIA NETO, A \& ZOTELLI, L. C. Caracterização das águas residuárias para reúso agrícola. Piracicaba, SP: Centro de Tecnologia Canavieira (CTC), 2008. 31p.

ELIA NETO, A., Biogás a partir de Vinhaça Vinhaça, In 2ª ${ }^{a}$ Conferência Biogás e Bioeletricidade 2014. São Paulo, 2014.

EU. Directiva 2009/28/CE do Parlamento Europeu e do Conselho de 23 de Abril de 2009 relativa à promoção da utilização de energia proveniente de fontes renováveis que altera e subsequentemente revoga as Directivas 2001/77/CE e 2003/30/CE L 140/16 PT. Jornal Oficial da União Europeia. Bruxelas, 05 jun 2009.

FERREIRA, E. S.; MONTEIRO, A. O. Efeitos da aplicação da vinhaça nas propriedades químicas, físicas e biológicas do solo. Boletim Técnico Copersucar, Piracicaba, v.37, p.3-7, 1987.

FNR - FACHAGENTUR NACHWACHSENDE ROHSTOFFE. Guia Prático do Biogás. Geração e Utilização. Ministério da Nutrição, Agricultura e Defesa do Consumidor da Alemanha. $5^{\text {a }}$ edição, Gülzow, 2010.

GEA Wiegand GmbH. Evaporators for Stillage Concentration Evaporation for Stillage Concentration. Ettlingen, 2007.

GLOEDEN, E., CUNHA, R.C.A., FRACCAROLI, M.J.B., CLEARY, R.W., The Behaviour of Vinasse Constituents in the Unsaturated and Saturated Zones in the Botucatu Aquifer Recharge Area. Water Science Technology. vol.24, n¹1, p.147-157, 1991.

GLÓRIA, N.A.; MAGRO, J.A., Utilização agrícola de resíduos da usina de açúcar e destilaria na Usina da Pedra, In: SEMINÁRIO COPERSUCAR DA AGROINDÚSTRIA AÇUCAREIRA, 4., Águas de Lindóia, 1976, Anais, São Paulo, Copersucar, p. 163-180,1977.

GLÓRIA, N.A.; ORLANDO FILHO, J., Aplicação de vinhaça como fertilizante. Boletim Técnico do Planalsucar, Araras, v.5, p.5-38, 1983. 
GLÓRIA, N.A.; ORLANDO FILHO, J., Aplicação de vinhaça: Um resumo e discussões sobre o que foi pesquisado, Revista Álcool Açúcar, v.16, p.32-39, 1984.

GNC Galileio S.A, Advantages of FEMTOBOX, 2014.

GOLDEMBERG. J., COELHO S.T., NASTARI P.M., LUCON O. Ethanol learning curve-the Brazilian experience. Biomass \& Bioenergy, vol.26, p 301- 304, 2004.

GUPTA, S.C.; SHULA, J.P. AND SHUKLA, N.P., Recovery of Crude Potassium Salts from Spent Wash of Molasses Distilleries by Fluidized Incineration, 1968-Proceedings of the 36th Annual Conv. Sugar Technology Ass., India, XXXXIII-1 to XXXXIII-7, 1968.

HASSUDA, S., Impactos da infiltração da vinhaça de cana no aquífero de Bauru, Dissertação (Mestrado em Recursos Minerais e Hidrogeologia) - Instituto de Geociências. Universidade de São Paulo, São Paulo, 92p, 1989.

HIRATA, R. C. A., BASTOS, C. R. A., ROCHA, G. A., GOMES, D. C. AND IRITANI, M. A., Groundwater pollution risk and vulnerability map of the state of São Paulo, Brazil. Water Science and Technology, v.24, n.11, p.159-169, 1991.

IPCC, Guidelines for National Greenhouse Gas Inventories, Prepared by the National Greenhouse Gas Inventories Programme, Eggleston H.S., Buendia L., Miwa K., Ngara T. and Tanabe K. (eds). Published: IGES, Japan, 2006.

ISENMANN, Armin Franz. Operações unitárias na indústria química. Timóteo/MG, 2013.

JORNALCANA. Usina Cerradinho concentra vinhaça com sucesso, Ribeirão Preto, SP, Julho/2009.

JORNALCANA. Vinhaça gera economia e melhora rendimento. Ribeirão Preto, SP, Junho/2007. p. 68.

JADOSKI, S.O.; SAITO, L.R.; Características da lixiviação de nitrato em áreas de agricultura intensiva, Pesquisa Aplicada \& Agrotecnologia v3 n1 Print-ISSN 1983-6325 (On line) eISSN 1984-7548, Jan.- Abr. 2010.

KLEIN, F. B.; FILHO, H. F.; ALMEIDA, P. Análise sobre o uso da Norma Técnica P4 . 231 da CETESB como preventiva aos impactos ambientais causados pela vinhaça. 1-16. 2008

LEME, E.J.A.; ROSENFELD, v.; BAPTISTELLA, J.R. Aplicação de vinhaça em cana-deaçúcar por aspersão. Boletim Técnico Planalsucar, Série B, v.1, n.4, p.3-42, 1979.

LETTINGA, G.; RINZEMA, A. Anaerobic treatment of sulfate containing wastewater, Bioenvironmental Systens, 1985.

LISBOA, C. C., BUTTERBACH-BAHL, K., MAUDER, M. and KIESE, R. Bioethanol production from sugarcane and emissions of greenhouse gases - known and unknowns. GCB Bioenergy, 3: 277-292, 2011.

LORENCINI, Vanessa da Silva. Estudo econômico das diferentes formas de transporte de vinhaça em fertirrigação na cana-de-açúcar. Dissertação (Mestrando em Agronomia ) - 
Faculdade de Ciências Agrárias e Veterinárias ,Universidade Estadual Paulista “Julio De Mesquita Filho.”, Jaboticabal, 2009.

LUDOVICE, M.T.F. Estudo do efeito da vinhaça infiltrada em canal condutor de terra sobre o lençol freático. Dissertação (Mestrado em Engenharia Civil) - Faculdade de Engenharia Civil, Universidade de Campinas, Campinas, 1997

LYRA, M. R. C. C., ROLIM, M. M., \& SILVA, J. A. A., Toposseqüência de solos fertigados com vinhaça: contribuição para a qualidade das águas do lençol freático. Rev. bras. eng. agríc. ambient, vol.7, no.3, Campina Grande Sept./Dec.2003.

MACEDO, I. C., SEABRA, J. E. A., \& SILVA, J. E. A. R., Greenhouse gases emissions in the production and use of ethanol from sugarcane in Brazil: The 2005/2006 averages and a prediction for 2020. Biomass and Bioenergy, 32(7), 582-595, 2008.

MACEDO, I.C. et al. Balanço das emissões de gases do efeito estufa na produção e uso do etanol no Brasil. Governo do Estado de São Paulo, Secretaria do Meio Ambiente. São Paulo. Abril, 2004.

MATIOLI, C.S.; MENEZES, J.A. Otimização dos sistemas de aplicação de resíduos líquidos na lavoura. In: REUNIÃO TÉCNICA AGRONÔMICA, Piracicaba, 1984. Anais. Piracicaba: Copersucar, 1984. p.67-70.

MCTI - MINISTÉRIO DA CIÊNCIA, TECNOLOGIA E INOVAÇÃO. Secretaria de Políticas e Programas de Pesquisa e Desenvolvimento. Coordenação Geral de Mudanças Globais de Clima. Estimativas anuais de emissões de gases de efeito estufa no Brasil. Brasília, 2013.

MME - MINISTERIO DE MINAS E ENERGIA. Balanço Energético Nacional 2012, Empresa de Pesquisa Energética - EPE, 2013.

MONTEIRO, C.E. Brazilian experience with the disposal of waste water from the cane sugar and alcohol industry. Process Biochemistry, 10(9):33-41, Nov. 1975.

MORENO, M., COELHO, S.T., Biodigerir e concentrar a vinhaça, uma solução económica, energética e ambiental, Biomais, vol.2, p. 64 - 70, 2014.

NEM. Spent Wash Treatment with Energy Recovery by NEM. Artigo técnico fornecido pela NEM, p.1-7, 2007

NOLASCO, J.J. Eficiência de processo térmico para mostos à base de caldo de cana e melaço na produção de bioetanol. Tese de Doutorado. Faculdade de Engenharia de Alimentos, Universidade de Campinas, Campinas, 2010.

OLIVEIRA, B. G.; CARVALHO, J. L. N.; CERRI, C. E. P., CERRI, C. C.; FEIGL, B. J.; Soil greenhouse gas fluxes from vinasse application in Brazilian sugarcane areas. Geoderma, 200-201, 77-84, 2013.

OLIVEIRA, B.G., Vinhaça da cana-de-açúcar: fluxos de gases de efeito estufa e comunidades de archaea presente no sedimento do canal de distribuição. Dissertação de Mestrado, ESALQ, Piracicaba, 2010. 
ORLANDO FILHO, J.; SILVA, G.M.A.; LEME, E.J.A. Utilização agrícola dos resíduos da agroindústria canavieira. In: PROGRAMA NACIONAL DE MELHORAMENTO DA

CANA-DE-AÇÚCAR. Vinhaça de cana-de-açúcar Nutrição e adubação da cana-de-açúcar no Brasil. Piracicaba, 1983. cap.10, p. 229-264. (Coleção Planalsucar, 2).

PAREDES, Débora da Silva. Emissão de óxido nitroso e metano proveniente da vinhaça em lagoas e canais de distribuição e após fertirrigação. 2011. 90f. Dissertação (Mestrado em Agronomia, Ciência do Solo) - Instituto de Agronomia, Departamento de Solos, Universidade Federal Rural do Rio de Janeiro, Seropédica, RJ, 2011.

PECORA, V. Implantação de uma Unidade Demonstrativa de Geração de Energia Elétrica a partir do Biogás de Tratamento do Esgoto Residencial da USP - Estudo de Caso. 152 p. Dissertação (Mestrado em Ciências) - Programa Interunidades de Pós-Graduação em Energia da Universidade de São Paulo - PIPGE. 2006

PERERA, C.J.G.H., Concentración y combustión de vinazas, San Miguel de Tucumán, República Argentina, 2009.

PINTO, C.P. Tecnologia da Digestão Anaeróbia da Vinhaça e Desenvolvimento

Sustentável. Dissertação (Mestrado em Planejamento de Sistemas Energéticos) - Faculdade de Engenharia Mecânica. Universidade Estadual de Campinas . Campinas/SP: [s.n.], 1999.

POMPERMAYER R. S., PAULA JR D.R. Estimativa do potencial brasileiro de produção de biogás através da biodigestão da vinhaça e comparação com outros energéticos. In: $3^{\circ}$ ENCONTRO DE ENERGIA NO MEIO RURAL, Anais, Setembro, 2000.

PROCKNOR, C. Energia elétrica a partir vinhaça. UNICA, 2009. Disponível em: < http://www.unica.com.br/convidados/25641156920337715081/energia-eletrica-a-partir-davinhaca/>. Acesso em: $10 \mathrm{dez} 2014$.

RIGHETTO, A.M. CRUZ, R.L NOGUEIRA, M.A. Experimental Investigation of Soil and Groundwater Impacts Caused by Vinasse Disposal. Water Science Technology, vol.24, $\mathrm{n}^{\mathrm{o}} 11$, p.77-85, 1991.

ROCHA, M. H., Uso da Análise do Ciclo de Vida para Comparação do Desempenho Ambiental de Quatro Alternativas para Tratamento da Vinhaça, Itajubá, 234p. Dissertação (Mestrado em Conversão de Energia) - Instituto de Engenharia Mecânica, Universidade Federal de Itajubá, 2009.

RODRIGUES, A.H. Três patamares tecnológicos na produção de etanol: a usina do proálcool, a usina atual e a usina do futuro. 2008. 160 p. Tese (Doutorado em Ciências Sociais em Instituições, Mercado e Regulação). Curso de Pós-Graduação em Desenvolvimento, Agricultura e Sociedade, Universidade Federal Rural do Rio de Janeiro, Rio de Janeiro, RJ, 2008.

ROSSETTO, A. J. Utilização Agronômica Dos Subprodutos E Resíduos Da Indústria Açucareira E Alcooleira. Paranhos, S.B. (ed.). Cana-de-açúcar: cultivo e utilizaçãa, Campinas: Fundação Cargill, 1987. 435-504.

SALOMON, Karina Riberio. Avaliação Técnico-Econômica e Ambiental da Utilização do Biogás Proveniente da Biodigestão da Vinhaça em Tecnologias para Geração de 
Eletricidade, 2007 Itajubá, 219 p. Tese (Doutorado em Conversão de Energia) Instituto de Engenharia Mecânica, Universidade Federal de Itajubá, Itajubá, 2007.

SÃO PAULO (Estado), Lei n ${ }^{\circ} 6.134$, de 02/06/1988 Dispõe sobre a preservação dos depósitos naturais de águas subterrâneas do Estado de São Paulo e dá outras providências. Diario Oficial do Estado, São Paulo, 3 de Junho de 1988.

SCHOPF, N.; ERBINO, P. Combustion Technology for LCV Fuels like Vinasse in the Sugar Industry SAACKE Swirl Burner SSBS-LCG. In: WORKSHOP OF CO-PRODUCTS INTERNATIONAL SOCIETY OF SUGAR CANE TECHNOLOGISTS, Maceió, Alagoas, 2006. Proceedings do ISSCT Co Products Workshop. Proceedings in CD, Maceio, 12-16 of November, 2006.

SEABRA, J.E.A. Análise de opções tecnológicas para uso integral da biomassa no setor de cana-de-açúcar e suas implicações. Tese (Doutorado em Planejamento de Sistemas Energéticos)- Programa de Pós-graduação da Faculdade de Engenharia Mecânica, Universidade Estadual de Campinas, Campinas, 2008.

SGC - SWEDISH GAS TECHNOLOGY CENTRE LTD. Basic data on biogas, 2nd ed., p. 23, Munken, 2012.

SILVA, M. A. S.; GRIEBELER, N. P.; BORGES, L. C. Uso de vinhaça e impactos nas propriedades do solo e lençol freático. Rev. bras. eng. agríc. ambient., vol.11, no.1, Campina Grande, Jan./Feb., 2007.

SILVA, A. Vinhaça concentrada de cana-de-açúcar: monitoramento das propriedades químicas do solo e mineralização líquida de nitrogênio. 2012. 109 f. Tese (Doutorado) Centro de Energia Nuclear na Agricultura, Universidade de São Paulo, Piracicaba, 2012.

SOARES, L.H.B. et. al. Mitigação das emissões de gases efeito estufa pelo uso de etanol da cana-de-açúcar produzido no Brasil. Circular Técnica, 27. Brasília: Ministério da Agricultura, Pecuária e Abastecimento, 2009.

SOUZA, M. E., FUZARO, G. \& POLEGATO, A. R. Thermophilic Anaerobic Digestion of Vinasse in Pilot Plant UASB Reactor. Water Science and Technology, v. 25, n. 7, p. 191200, 1992.

SOUZA, S. A. V., Disponibilidade Vinhaça: o avanço das tecnologias de uso. In: MACEDO, I. C. (org.), A energia da cana-de-açúcar: doze estudos sobre a agroindústria da cana-deaçúcar no Brasil e a sua sustentabilidade. UNICA, São Paulo, 2005.

ONU - ORGANIZAÇÃO DAS NAÇÕES UNIDAS. UNFCCC/CCNUCC. ACM0014 “Treatment of wastewater" Version 05.0.0, 2012.

UNICA. Histórico de produção e moagem. Disponível em:

<http://www.unicadata.com.br/unicadata>. Acesso em: $02 \mathrm{dez} 2013$.

URBAN, W.; GIROD, K.; LOHMANN, H. Technologien und Kosten der Biogasaufbereitung und Einspeisung in das Erdgasnetz. Ergebnisse der Markterhebung 2007-2008. 123 s. Fraunhofer-Institut für Umwelt-, Sicherheits- und Energietechnik, Oberhausen, German, 2009. 
USA. Public Law 110-140. Energy Independence and Security Act, Signed on December 19, 2007 by President Bush. City of Washington, 2007.

USEPA - United States Environment Protection Agency, Air Emission from Municipal Solids Waste Landfill - Background Information for Proposed Standards and Guidelines. Emission Standards Division. EPA-450/3-90-011a. USA, March/1991.

WORKSHOP TECNOLÓGICO VINHAÇA, Termo de Referência para o Workshop Tecnológico Vinhaça, Campus de Jaboticabal, Facultade de Ciências Agrarias e Vetereninarias, Departamento de Tecnologia, Universidade Estadual Paulista, Set/2007. 


\section{APÊNDICE A - Cálculo do volume de exaustão para caldeiras queimando vinhaça concentrada e gás Natural}

Para os cálculo da razão estequiométrica entre a massa de ar fornecido e massa de combustível $\left(A F_{s t}\right)$, apresenta-se os cálculos organizados na Tabela 51, mostrando as equações de combustão de cada um dos componentes da vinhaça concentrada $\left(65^{\circ} \mathrm{Bx}\right)$ para obter combustão completa (estequiométrica).

Tabela 51. Volume estequiométrico de gases de exaustão da combustão de vinhaça $65^{\circ} B x$.

\begin{tabular}{|c|c|c|c|c|}
\hline Combustível & $\begin{array}{l}\text { Composição } \\
\text { mássica }\end{array}$ & $\begin{array}{c}\text { Equações de } \\
\text { combustão }\end{array}$ & $\begin{array}{c}\text { Oxigênio necessário por } \\
\text { unidade de massa de } \\
\text { comb.(kg) }\end{array}$ & $\begin{array}{l}\text { Produto por unidade } \\
\text { de massa de comb. }\end{array}$ \\
\hline $\mathrm{C}$ & 0,2136 & $\begin{array}{c}\mathrm{C}+\mathrm{O}_{2}=\mathrm{CO}_{2} \\
12+32=44\end{array}$ & $0,2136(32 / 12)=0,5696$ & $\begin{array}{c}0,2136(44 / 12)= \\
0,7832 \mathrm{kgCO}_{2}\end{array}$ \\
\hline $\mathrm{H}_{2}$ & 0,0335 & $\begin{aligned} 2 \mathrm{H}_{2}+\mathrm{O}_{2} & =2 \mathrm{H}_{2} \mathrm{O} \\
4+32 & =36\end{aligned}$ & $0,0335(32 / 4)=0,268$ & $\begin{array}{c}0,0335(36 / 4)= \\
0,3015 \mathrm{kgH}_{2} \mathrm{O}\end{array}$ \\
\hline $\mathrm{O}_{2}$ & 0,2504 & - & $\begin{array}{c}-0,2504 \text { (Por ser parte do } \\
\text { combustível) }\end{array}$ & - \\
\hline $\mathrm{N}_{2}$ & 0,0126 & - & - & $0,0126 \mathrm{kgN}_{2}$ \\
\hline$S$ & 0,0083 & $\begin{array}{l}\mathrm{S}+\mathrm{O}_{2}=\mathrm{SO}_{2} \\
32+32=64\end{array}$ & $0,0083(32 / 32)=0,0083$ & $\begin{array}{c}0,0083(64 / 32)= \\
0,0166 \mathrm{kgSO}_{2}\end{array}$ \\
\hline Cinzas & 0,1316 & - & - & - \\
\hline \multirow[t]{2}{*}{ Água } & 0,3500 & - & - & 0,3500 \\
\hline & 1 & & Total $\mathrm{O}_{2}=0,5955$ & \\
\hline
\end{tabular}

Fonte: autor.

O oxigênio estequiométrico necessário por umidade de massa de combustível: 0,5955 $\mathrm{kgO}_{2}$. Assim, o ar teórico necessário por umidade de massa de combustível:

$$
\frac{0,5955}{0,233}=2,556 \mathrm{~kg}
$$

Obs: O ar tem 23,3\% de oxigênio em composição mássica.

O nitrogênio estequiométrico (teórico) associado com o ar teórico necessário.

$$
2,556 \times 0,767=1,96 \mathrm{~kg}
$$


Obs: $\mathrm{O}$ ar tem 76,7\% de nitrogênio em composição mássica.

O nitrogênio presente nos produtos de combustão é:

$$
1,96+0,0126=4,973
$$

Relação $\boldsymbol{A F _ { s t }}=\mathbf{2 , 5 5 6}$

A seguir, calcula-se a relação entre a massa de ar real fornecido e a massa de vinhaça combustível $\left(A F_{\text {real }}\right)$ para um excesso de $20 \%$ de ar.Para isto, determina-se a composição volumétrica em base seca e úmida dos produtos de combustão. Para o caso de fornecer $20 \%$ de ar em excesso $(\varepsilon)$ :

$$
\begin{gathered}
A F_{\text {real }}=\varepsilon A F_{\text {st }}+A F_{\text {st }} \\
A F_{\text {real }}=0,2 \times 2,556+2,556=3,067
\end{gathered}
$$

Quantidades de nitrogênio e oxigênio associados com quantidade de ar real:

$$
\begin{gathered}
N_{2}=0,767 \times 3,067=2,352 \mathrm{~kg} \\
O_{2}=0,233 \times 3,067=0,714611 \mathrm{~kg}
\end{gathered}
$$

Nitrogênio nos produtos de combustão:

$$
N_{2}=2,352+0,0126=2,365 \mathrm{~kg}
$$

Excesso de oxigênio fornecido:

\begin{tabular}{|c|c|c|c|c|c|}
\hline Produto & $\begin{array}{c}\text { Massa/ } \\
\text { kgComb. }\end{array}$ & $\%$ massa & $\begin{array}{c}\text { Massa } \\
\text { molecular }\end{array}$ & moles/kgComb. & \% volume \\
\hline $\mathrm{CO}_{2}$ & 0,7832 & $\frac{0,7832}{3,9353}=0,20$ & 44 & $\frac{783,2}{44}=17,8$ & $\frac{17,8}{142,43}=0,13$ \\
\hline $\mathrm{H}_{2} \mathrm{O}$ & $\begin{array}{c}0,3015+ \\
0,3500= \\
0,6515\end{array}$ & $\frac{0,6515}{3,9353}=0,17$ & 18 & $\frac{651,5}{18}=36,19$ & $\frac{36,19}{142,43}=0,25$ \\
\hline $\mathrm{SO}_{2}$ & 0,0166 & $\frac{0,0166}{3,9353}=0,004$ & 64 & $\frac{16,6}{64}=0,26$ & $\frac{0,26}{142,43}=0,002$ \\
\hline $\mathrm{O}_{2}$ & 0,119 & $\frac{0,119}{3,9353}=0,03$ & 32 & $\frac{119}{32}=3,72$ & $\frac{3,72}{142,43}=0,03$ \\
\hline $\mathrm{N}_{2}$ & 2,365 & $\frac{2,365}{3,9353}=0,60$ & 28 & $\frac{2.365}{28}=84,46$ & $\frac{84,46}{142,43}=0,59$ \\
\hline TOTAL & 3,9353 & 1 & & 142,43 & 1 \\
\hline
\end{tabular}

$$
\varepsilon O_{2}=0,715-0,596=0,119 \mathrm{~kg}
$$

A seguir, mostram-se na Tabela 52 os produtos da combustão da vinhaça, e sua composição mássica e volumétrica em base seca e úmida.

Tabela 52. Composição mássica e volumétrica em base seca e úmida dos produtos da combustão da vinhaça concentrada.

Fonte: autor. 
Queimando $1 \mathrm{~kg}$ de vinhaça $65^{\circ} \mathrm{Bx}$ se obtém 142,43 moles de gás de exaustão, que em condições normais corresponderia a $\underline{\mathbf{3 , 1 9} \mathrm{Nm}^{3}}$

Realizam-se, a seguir, os mesmos cálculos anteriores para o gás natural:

Tabela 53. Volume estequiométrico de gases de exaustão da combustão de gás natural

\begin{tabular}{ccccc}
\hline Combustível & $\begin{array}{c}\text { Composição } \\
\text { mássica }\end{array}$ & $\begin{array}{c}\text { Equações de } \\
\text { combustão }\end{array}$ & $\begin{array}{c}\text { Oxigênio necessário por } \\
\text { unidade de massa de comb. }\end{array}$ & $\begin{array}{c}\text { Produto por unidade } \\
\text { de massa de comb. }\end{array}$ \\
\hline $\mathrm{C}$ & 0,75 & $\begin{array}{c}\mathrm{C}+\mathrm{O}_{2}=\mathrm{CO}_{2} \\
12+32=44\end{array}$ & $0,75(32 / 12)=2 \mathrm{~kg}$ & $\begin{array}{c}0,75(44 / 12)= \\
2,75 \mathrm{kgCO}_{2}\end{array}$ \\
& 0,25 & $\begin{array}{c}2 \mathrm{H}_{2}+\mathrm{O}_{2}=2 \mathrm{H}_{2} \mathrm{O} \\
4+32=36\end{array}$ & $0,25(32 / 4)=2 \mathrm{~kg}$ & $\begin{array}{c}0,25(36 / 4)= \\
2,25 \mathrm{kgH}_{2} \mathrm{O}\end{array}$ \\
\hline $\mathrm{H}_{2}$ & & & Total $\mathrm{O}_{2}=4 \mathrm{~kg}$ \\
\hline
\end{tabular}

Fonte: autor.

Oxigênio estequiométrico necessário por umidade de massa de combustível: $4 \mathrm{kgO}_{2}$ Ar teórico necessário por umidade de massa de combustível:

$$
\frac{4}{0,233}=17,17 \mathrm{~kg}
$$

Nitrogênio estequiométrico (teórico) associado com o ar teórico necessário.

$$
17,17 \times 0,767=13,17 \mathrm{~kg}
$$

Para o caso de fornecer $10 \%$ de ar em excesso $(\varepsilon)$ :

$$
\begin{gathered}
A F_{\text {real }}=\varepsilon A F_{\text {st }}+A F_{\text {st }} \\
A F_{\text {real }}=0,1 \times 17,17+17,17=18,887
\end{gathered}
$$

Quantidades de nitrogênio e oxigênio associados com quantidade de ar real.

$$
\begin{gathered}
N_{2}=0,767 \times 18,88=14,48 \mathrm{~kg} \\
\mathrm{O}_{2}=0,233 \times 18,88=4,4 \mathrm{~kg}
\end{gathered}
$$

Excesso de oxigênio fornecido:

$$
\varepsilon O_{2}=4,4-4=0,4 \mathrm{~kg}
$$

A seguir, mostram-se na Tabela 54 os produtos da combustão do gás natural, e sua composição mássica e volumétrica em base seca e úmida. 
Tabela 54. Composição mássica e volumétrica em base seca e úmida dos produtos da combustão gás natural.

\begin{tabular}{|c|c|c|c|c|c|}
\hline Produto & $\begin{array}{c}\text { Massa/ } \\
\text { kgComb. }\end{array}$ & $\%$ massa & $\begin{array}{c}\text { Massa } \\
\text { molecular }\end{array}$ & moles/kgComb. & \% volume \\
\hline $\mathrm{CO}_{2}$ & 2,75 & $\frac{2,75}{19,88}=0,14$ & 44 & $\frac{2.750}{44}=62,5$ & $\frac{62,5}{717,14}=0,09$ \\
\hline $\mathrm{H}_{2} \mathrm{O}$ & 2,25 & $\frac{2,25}{19,88}=0,11$ & 18 & $\frac{2.250}{18}=125$ & $\frac{125}{717,14}=0,17$ \\
\hline $\mathrm{O}_{2}$ & 0,4 & $\frac{0,4}{19,88}=0,02$ & 32 & $\frac{400}{32}=12,5$ & $\frac{12,5}{717,14}=0,02$ \\
\hline $\mathrm{N}_{2}$ & 14,48 & $\frac{14,48}{19,88}=0,73$ & 28 & $\frac{14.480}{28}=517,14$ & $\frac{517,14}{717,14}=0,72$ \\
\hline TOTAL & 19,88 & 1 & & 717,14 & 1 \\
\hline
\end{tabular}

Fonte: autor.

Queimando $1 \mathrm{~kg}$ de gás natural se obtém 717,14 moles de gás de exaustão, que em condições normais corresponderia a $16,06 \mathrm{Nm}^{3}$.

Devido a que a massa específica do gás natural em condições normais é $0,78 \mathrm{~kg} / \mathrm{m}^{3}$ e o volume utilizado deste combustível é de $0,02 \mathrm{Nm}^{3}$ por cada $\mathrm{kg}$ de vinhaça com $65^{\circ} \mathrm{Bx}$,

$$
\begin{array}{cc}
\mathrm{V}_{\mathrm{Ex} / \mathrm{V} 4^{\circ} \mathrm{Bx}}=\mathrm{m}_{65^{\circ} \mathrm{Bx} / \mathrm{V} 4^{\circ} \mathrm{Bx}} \times\left(\mathrm{v}_{\mathrm{Ex} / \mathrm{kg} 65^{\circ} \mathrm{Bx}}+\mathrm{v}_{\mathrm{GN} / \mathrm{kg} 65^{\circ} \mathrm{Bx}} \times \rho_{\mathrm{GN}} \times \mathrm{v}_{\mathrm{Ex} / \mathrm{kgGN}}\right) & \text { Equação } 54 \\
\mathrm{~V}_{\mathrm{Ex} / \mathrm{ano}}=\mathrm{v}_{\mathrm{Ex} / \mathrm{V} 4^{\circ} \mathrm{Bx}} \times \mathrm{V}_{4^{\circ} \mathrm{Bx} / \mathrm{ano}} & \text { Equação } 55
\end{array}
$$

Onde:

\section{Dados de entrada}

\begin{tabular}{llll} 
Símbolo & Significado & Valor & Fonte \\
$\mathrm{V}_{4^{\circ} \mathrm{Bx} / \mathrm{ano}}$ & Volume de vinhaça $4^{\circ} \mathrm{Bx}$ produzido por ano & $960.000 \mathrm{~m}^{3}$ & Tabela 2 \\
$\mathrm{~m}_{65^{\circ} \mathrm{Bx} / \mathrm{V} 4^{\circ} \mathrm{Bx}}$ & Massa de vinhaça com $65^{\circ} \mathrm{Bx}$ por $\mathrm{m}^{3}$ de vinhaça $4^{\circ} \mathrm{Bx}$ & $62,4 \mathrm{~kg} / \mathrm{m}^{3}$ & Tabela 15 \\
$\mathrm{~V}_{\mathrm{GN} / \mathrm{kg} 65^{\circ} \mathrm{Bx}}$ & Volume de GN por cada kg de vinhaça com $65^{\circ} \mathrm{Bx}$ & $0,02 \mathrm{Nm}^{3} / \mathrm{kg}$ & SAACKE, 2013 \\
$\rho_{\mathrm{GN}}$ & Massa especifica do gás natural & $0,78 \mathrm{~kg} / \mathrm{Nm}^{3}$ & \\
$\mathrm{~V}_{\mathrm{Ex} / \mathrm{kgGN}}$ & Volume de exaustão por kg de gás natural queimado & $16,06 \mathrm{Nm}^{3} / \mathrm{kg}$ & \\
$\mathrm{v}_{\mathrm{Ex} / \mathrm{kg} 65^{\circ} \mathrm{Bx}}$ & Volume de exaustão por kg de vinhaça $65^{\circ} \mathrm{Bx}$ queimado & $3,19 \mathrm{Nm}^{3} / \mathrm{kg}$ & \\
& \multicolumn{1}{c}{ Resultados } & & \\
$\mathrm{v}_{\mathrm{Ex} / \mathrm{V} 4^{\circ} \mathrm{Bx}}$ & Volume de exaustão por $\mathrm{m}^{3}$ de vinhaça $4^{\circ} \mathrm{Bx}$ & $214,69 \mathrm{Nm}^{3} / \mathrm{m}^{3}$ & Equação 54 \\
$\mathrm{~V}_{\mathrm{Ex} / \text { ano }}$ & Volume de exaustão por ano & $206,1 \times 10^{6} \mathrm{Nm}^{3}$ & Equação 55 \\
\hline
\end{tabular}

